\title{
OCUPAÇÃO TERRITORIAL E QUALIDADE DA ÁGUA SUBTERRÂNEA EM MACIÇO FRATURADO NA REGIÃO DE ITAQUERA, SÃO PAULO - SP
}

\author{
VALDENEIDE REGINA DA SILVA
}

Orientador: Prof. Dr. Fabio Taioli

DISSERTAÇÃO DE MESTRADO

COMISSÃO JULGADORA

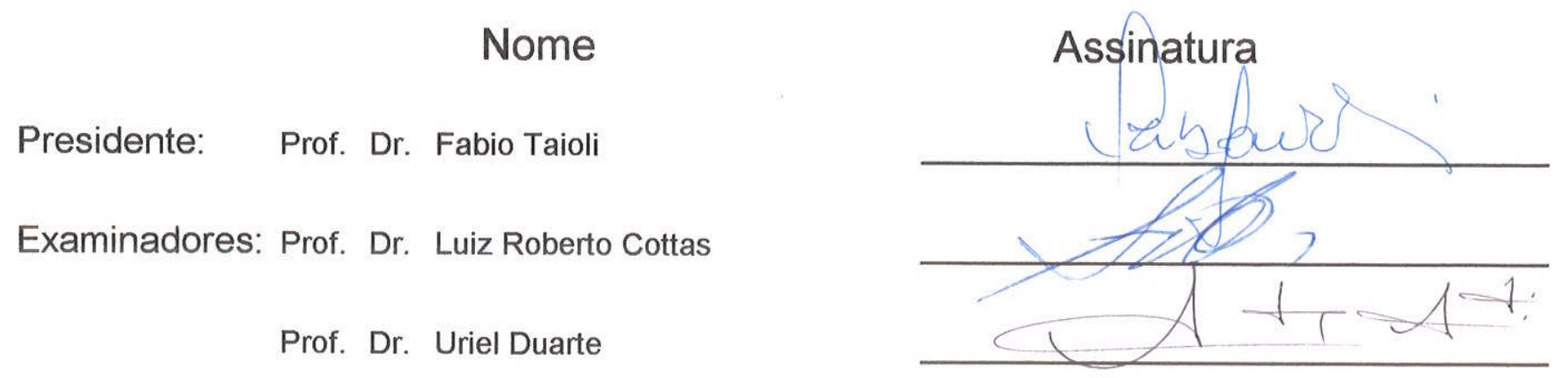

SÃO PAULO

2000 


\section{UNIVERSIDADE DE SÃO PAULO INSTITUTO DE GEOCIÊNCIAS}

\section{OCUPAÇÃO TERRITORIAL E QUALIDADE DA ÁGUA SUBTERRÂNEA EM MACIÇO FRATURADO NA REGIÃO DE ITAQUERA, SÃO PAULO - SP}

Valdeneide Regina da Silva

Orientador: Prof. Dr. Fabio Taioli

\section{DISSERTAÇÃO DE MESTRADO}

Programa de Pós-Graduação em Recursos Minerais e Hidrogeologia

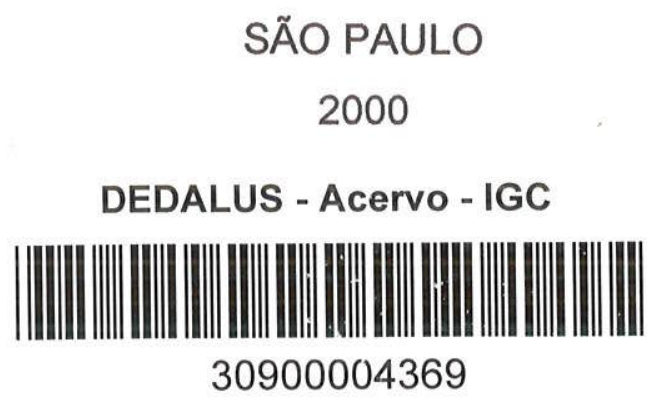




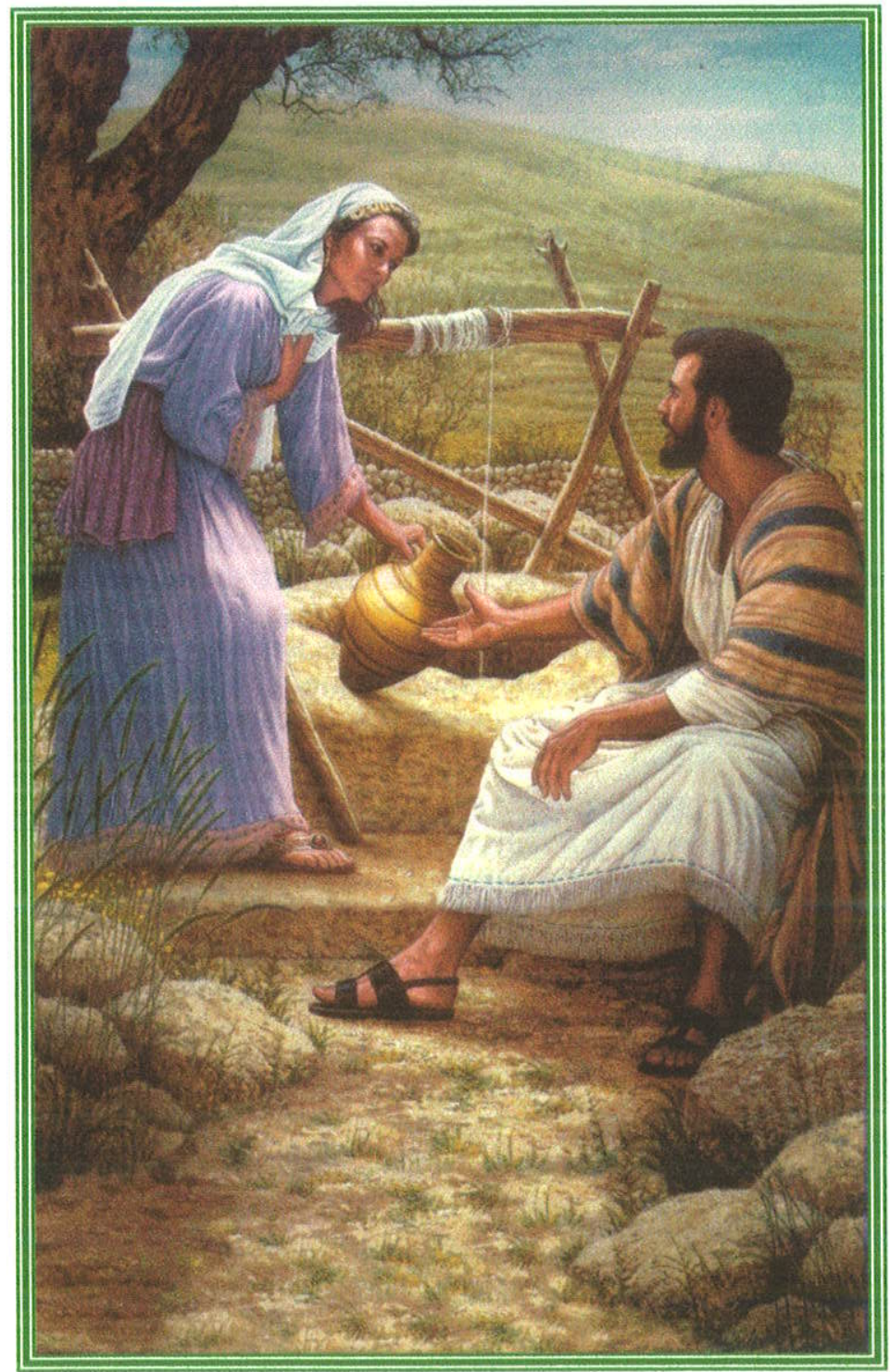

Jesus disse, em resposta, à samaritana: "Todo aquele que beber desta água ficará novamente com sede. Quem beber da água que eu Ihe der, nunca mais ficará com sede, mas a água que eu the der se tornará nele uma fonte de água que borbulha para dar vida eterna".

(João 4:13,14) 


\section{AGRADECIMENTOS}

Agradeço ao meu orientador Prof. Dr. Fábio Taioli pela orientação exemplar, sugestões, críticas e incentivo, além da compreensão e amizade desde o inicio da pesquisa.

Ao Prof. Dr. Ginaldo A. Campanha pela orientação no levantamento de campo e tratamento de dados estruturais, incluindo dicas sobre programas computacionais (stereoNet e TRADE) e pelas sugestões.

Ao Prof. Dr. Uriel Duarte, pelo empréstimo de materiais (papers e equipamentos de campo), pelas dicas e amizade.

Ao Prof. Dr. Ricardo C. A. Hirata pelas discussões e sugestões sobre hidrogeologia, pelos materiais cedidos (papers) e equipamentos emprestados ( $\mathrm{pHmetro} \mathrm{e} \mathrm{condutivímetro).}$

Ao amigo e Prof. Dr. Nélson Angeli, da UNIVERSIDADE ESTADUAL PAULISTA UNESP (Campus Rio Claro), pelas correções de texto e incentivo ao trabalho.

À FUNDAÇÃO DE AMPARO A PESQUISA DO ESTADO DE SÃO PAULO - FAPESP, pelo financiamento da pesquisa (processo 97/11450-2).

À COORDENAÇÃO DE APERFEIÇOAMENTO DE PESSOAL DE NIVEL SUPERIOR CAPES, pela bolsa de estudos concedida no periodo de dois anos.

Ao CENTRO DE PESQUISAS DE ÁGUAS SUBTERRÂNEAS DA UNIVERSIDADE DE SÃO PAULO (CEPAS/IG-USP), pelo empréstimo de material (relatório e mapas) e pelo financiamento das análises químicas realizadas em um de seus laboratórios (Laboratório de Hidrogeoquimica (I).

À JUNDSONDAS - POÇOS ARTESIANOS LTDA pela concessão de dados técnicos referentes aos poços tubulares perfurados na área de estudo.

O meu agradecimento especial a uma das pessoas que muito contribuiu para este trabalho, o colega de pós-graduação deste instituto e geólogo da COMPANHIA DE DESENVOLVIMENTO HABITACIONAL E URBANO DO ESTADO DE SÃO PAULO (CDHU), Flávio Almeida da Silva, pelos trabalhos realizados em conjunto (especialmente os relacionados à análise estrutural), pelos materiais cedidos e emprestados, pelas discussões e sugestões, além da amizade. 


\section{SUMÁRIO}

INDICE DE FIGURAS IV

INDICE DE TABELAS viii

RESUMO IX ix

ABSTRACT $\quad$ xi

1 - INTRODUÇÃO

1.1 - Considerações iniciais 1

1.2 - Objetivos 2

2 - ÁREA DE ESTUDO 3

2.1 - Localização e vias de acesso 3

2.2 - Geomorfologia 5

2.3 - Hidrografia 6

2.4 - Clima 10

2.5 - Histórico de uso e ocupação 10

3 - REVISÃO BIBLIOGRÁFICA

3.1 - Quadro geológico regional 15

3.1 .1 - Aspectos litoestratigráficos $\quad 15$

3.1.2 - Aspectos tectônicos e estruturais $\quad 17$

3.1 .3 - Evolução tectônica cenozóica 20

3.2 - Geologia local 22

3.3 - Análise cinemático-estrutural 24

3.3.1 - Determinação da direção e sentido do movimento em falhas rúpteis 24 3.3.1.1 - Método Arthaud 24

3.3.1.2 - Método dos diedros retos ou Método de Angelier 25

3.3.2 - Aplicação em estudos de hidrogeologia 26

3.4 - Hidrogeologia 27

3.4.1 - Importância e uso das águas subterrâneas 27

3.4 .2 - Hidrogeologia de aqüiferos fraturados 28

3.4.2.1 - Generalidades 28

3.4.2.2 - Fatores que atuam na capacidade de armazenamento de água $\quad 30$

3.4.2.2.1 - Fatores endógenos $\quad 30$ 
Aos amigos e colegas da pós-graduação do Departamento de Geologia Sedimentar e Ambiental (GSA), especialmente à amiga e geóloga Silvia Maria Ferreira, pela sua amizade e incentivo ao trabalho, além de todas as ajudas práticas prestadas.

À geóloga Patrícia Braga Toledo lezzi pelo apoio nos trabalhos de campo, principalmente durante a fase de coleta de amostras de água.

Aos alunos de graduação em geologia e estagiários desse instituto, Diego Romano e Sidney Schaberle Goveia, pelos trabalhos referentes à digitalização e edição de figuras em autoCad e confecção de mapas no SIG (Sistema de Informação Geográfica) idrisi, respectivamente.

Aos funcionários Reynaldo Peña Castellon (DGG) pela digitalização e edição de figuras em autoCad, Sérgio Ataide (CEPAS/IG-USP) pela ajuda nos trabalhos de campo, à bibliotecária Maristela Prestes Severino (biblioteca IG-USP) pela normalização das referências bibliográficas e aos funcionários da gráfica pelo capricho nos serviços prestados.

Aos meus pais queridos pais pelo carinho, compreensão e apoio durante todo o curso e ao meu querido irmão pelo auxilio na fase final do trabalho. 
3.4.2.2.2 - Fatores exógenos $\quad 34$

3.4.2.3 - Fluxo em meios fraturados $\quad 37$

3.4.2.3.1 - Generalidades $\quad 37$

3.4.2.3.2 - Fluxo em maciços rochosos 41

3.4.3 - Características hidrogeológicas do aqüifero cristalino da RMSP 46

4 - MATERIAL E MÉTODOS 48

4.1 - Levantamento geológico 48

4.2 - Levantamento do uso e ocupação territorial 49

4.3 - Levantamento hidrogeológico 49

4.3.1 - Cadastramento de poços e pontos d'água 49

4.3.2 - Análises químicas $\quad 50$

5 - TRABALHOS REALIZADOS

5.1 - Levantamento geológico 54

5.1 .1 - Caracterização geológica da área 54

5.1 .2 - Análise estrutural 57

5.1.2.1 - Análise cinemático-estrutural $\quad 64$

5.2 - Levantamento do uso e ocupação territorial 69

5.3 - Levantamento hidrogeológico 82

5.3.1 - Cadastramento de poços e pontos d'água 82

5.3.1.1 - Características dos poços $\quad 85$

5.3.1.1.1 - Profundidade 85

5.3.1.1.2 - Aspectos construtivos e de conservação dos poços $\quad 85$

5.3.1.2 - Produção dos poços 88

5.3.1.2.1 - Vazão e capacidade específica 88

5.3.1.3 - Características dos aqüiferos 88

5.3.1.3.1 - Profundidade das entradas de água 88

5.3.1.3.2 - Nivel estático 89

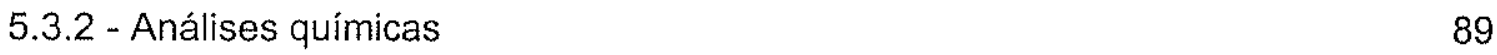

5.3.2.1 - Verificação da validade das análises $\quad 89$

5.3.2.2 - Parâmetros físicos 93

5.3.2.2.1 - Temperatura 93

5.3.2.2.2 - Condutividade elétrica 94

5.3.2.3 - Parâmetros quimicos $\quad 96$

5.3.2.3.1 - pHe Eh 97

$\begin{array}{ll}\text { 5.3.2.3.2 - Alcalinidade } & 97\end{array}$ 
5.3.2.4 - Classificação das águas

5.3.2.5 - Qualidade das águas

6 - DISCUSSÃO DOS RESULTADOS 110

7 - CONCLUSÕES E RECOMENDAÇÕES 117

REFERÊNCIAS BIBLIOGRÁFICAS

ANEXOS 


\section{INDICE DE FIGURAS}

Figura 1 - Localização da área de estudo.

Figura 2 - Mapa de relevo da área de estudo.

Figura 3 - Mapa de declividade da área de estudo.

Figura 4 - Sub-bacias hidrográficas da área de estudo e suas localizações na Bacia do Alto Tietê.

Figura 5 - Distribuições mensais das chuvas na região de Itaquera/Guaianazes, no período de 1995 a 1999.

Figura 6 - Principais falhamentos transcorrentes do embasamento cristalino do Estado de São Paulo (IPT, 1981b).

Figura 7 - Mapa geológico da folha Mauá - parcial (CEPAS, 1994).

Figura 8 - Bloco diagrama mostrando um bloco falhado e a posição dos eixos X, Y e Z, no conceito de Arthaud (1969).

Figura 9 - Plano M, no conceito de Arthaud (1969).

Figura 10 - Esquema dos diedros retos de compressão (C) e de extensão (E) numa região afetada pela falha PF. Notar que o PA é ortogonal às estrias (S) e não ao mergulho real da falha (m).

Figura 11 - Esquema do princípio elementar do método dos diedros retos mostrando um esquema em extensão. $O$ somatório das duas primeiras figuras vai dar a última.

Figura 12 - Quando o estado de tensões atuante corresponde ao representado pelos eixos $a, b, c$, podem se desenvolver fraturas de cisalhamento (hk0 de Sander) ou de tração (ac) (COSTA \& SILVA, 1997).

Figura 13 - Fraturamento em dobras de grande raio de curvatura. A fratura mais central coincide com o plano axial e contém a crista da dobra (fratura $\underline{b c}$ de Sander). As demais desse tipo (paralelas a $\underline{b c}$ ) apresentam ligeiro mergulho para o centro da dobra (COSTA \& SILVA, 1997).

Figura 14 - Fraturas longitudinais desenvolvidas ao longo dos planos de xistosidade por alivio de pressão (COSTA \& SILVA, 1997).

Figura 15 - Esquema da formação das juntas de descompressão ou "sheet joints". Por erosão, a tensão $\sigma_{3}$ passa de compressiva para tracional, acarretando o fendilhamento paralelo à superficie topográfica (COSTA \& SILVA, 1997).

Figura 16 - Tipos de infiltração e preenchimento de fraturas: (a) o material de preenchimento provém da própria rocha; (b) o material infiltrou-se em meio aquoso superficial decantando dentro da fratura; (c) o material entrou 
em solução a partir da superficie; (d) percolação por solução hidrotermal (COSTA \& SILVA, 1997).

Figura 17 - Comportamento esperado da permeabilidade em diferentes litologias em função da profundidade (AZEVEDO \& ALBUQUERQUE, 1998).

Figura 18 - Maciço rochoso fraturado, evidenciando os parâmetros de interesse ao fluxo (RISSLER, 1978 apud QUADROS, 1982).

Figura 19 - Elipsóide de condutividade hidráulica num sistema de referência X, Y, Z (QUADROS, 1992).

Figura 20 - Conceito de Volume Elementar Representativo (V.E.R.) (BEAR, 1972).

Figura 21 - Trajetórias de fluxo nos ensaios direcionais. Esquematização para três furos e quatro trechos de ensaios e observação (QUADROS, 1992).

Figura 22 - Mapa geológico da área de estudo (modificado de CEPAS, 1994).

Figura 23 - Vista geral de perfil de intemperismo de xisto e/ou filito, num corte de estrada (afloramento 3 ).

Figura 24 - Afloramento de granito-gnaisse, em cava de pedreira, mostrando a pequena espessura do manto de intemperismo desenvolvida por este litotipo (afloramento 9). Altura aproximada do afloramento $=8 \mathrm{a}$ 10 metros.

Figura 25- Mapa de lineamentos a partir de fotografia aérea (foto 331 , faixa $8 \mathrm{C}$ ).

Figura 26 - Diagramas de rosáceas mostrando as direções predominantes dos lineamentos em relação ao tamanho (a) e ao número (b) de lineamentos.

Figura 27 - Diagrama de Schmidt-Lambert (hemisfério inferior) com os polos dos planos de bandamento do granito-gnaisse e dos planos de xistosidade dos filitos e xistos.

Figura 28 - Diagrama de Schmidt-Lambert (hemisfério inferior) com os polos dos planos das fraturas medidas no granito-gnaisse.

Figura 29 - Diagrama de Schmidt-Lambert (hemisfério inferior) com os polos dos planos das fraturas medidas nos filitos e xistos.

Figura 30 - Diagrama de contorno de densidade de polos dos planos de fraturas do granito-gnaisse.

Figura 31 - Diagrama de contorno de densidade de polos dos planos de fraturas dos filitos e xistos. 
Figura 32 - Ressaltos em espelho de falha, em granito-gnaisse, indicando movimento dextral. A seta indica o sentido do movimento do bloco de cima (Figura 22 - afloramento 9).

Figura 33 - Ressaltos em espelho de falha, em granito-gnaisse, indicando movimento sinistral. A seta indica o sentido do movimento do bloco de cima (Figura 22 - afloramento 9).

Figura 34 - Ressaltos em plano de fratura, em bolsão pegmatítico, indicando movimento sinistral. A seta indica o sentido do movimento do bloco da frente (Figura 22 - afloramento 14).

Figura 35 - Ressaltos em plano de fratura, em granito-gnaisse, indicando movimento sinistral. A seta indica o sentido do movimento do bloco da frente (Figura 22 - afloramento 14).

Figura 36 - Análise pelo Método de Angelier das falhas geradas por um campo principal de esforço $\left(\sigma_{1}\right)$ horizontal e N-S.

Figura 37 - Análise pelo Método de Angelier das falhas geradas por um campo principal de esforço $\left(\sigma_{1}\right)$ horizontal e E-W.

Figura 38 - Mapa de lineamentos com indicação das prováveis fraturas abertas (foto 331 , faixa $8 \mathrm{C}$ ).

Figura 39 - Mapa de uso e ocupação da área de estudo (IEZZI, 1999).

Figura 40 - Mapa de localização das empresas e/ou estabelecimentos visitados.

Figura 41 - Local de lavagem e recuperação de tambores localizado em área de várzea, mostrando pontos de alagamento.

Figura 42 - Armazenamento irregular de sacos plásticos, contendo areia de fundição e produtos químicos, em depósito de tambores e bombonas.

Figura 43 - Borda da APA Mata do Iguatemi mostrando o ressecamento da vegetação devido a atividades antrópicas desenvolvidas em terreno adjacente onde se realizava a atividade de lavagem e recuperação de tambores (ponto 89 - Ranchonete do Gaúcho).

Figura 44 - Mapa de localização de fontes potenciais de contaminação das águas subterrâneas.

Figura 45 - Câmaras de tratores e de caminhões dispostos irregularmente na margem da estrada U. (Figura 44 - ponto 2)

Figura 46 - Ponto de descarte de resíduos sólidos onde se observam pneus, materiais plásticos (potes e fitas) e entulho (madeira e terra). (Figura $44-$ ponto 3 )

Figura 47 - Lã de vidro parcialmente queimada disposta irregularmente num ponto de descarte de residuos próximo à estrada U. (Figura 44 ponto 4 ) 
Figura 48 - Ponto de descarte de resíduos na margem da estrada $U$, com disposição irregular de meias, embalagens plásticas e troncos de árvore. No fundo, reflorestamento de eucaliptos. (Figura 44 - ponto 5)

Figura 49 - Mapa de localização dos poços e pontos d'água cadastrados.

Figura 50 - Distribuição dos poços tubulares de acordo com os tipos de estabelecimentos instalados na área.

Figura 51 - Distribuição dos poços cacimbas de acordo com os tipos de estabelecimentos instalados na área.

Figura 52 - Freqüência de distribuição das profundidades dos poços tubulares. (número de poços $=30$ )

Figura 53 - Freqüência de distribuição das profundidades dos poços cacimbas. (número de poços $=89$ )

Figura 54 - Aspecto de preservação do poço 95 - Recicladora de Sucatas Rodoplast, mostrando o uso de pedaços de telha para cobrir o poço na ausência de tampa.

Figura 55 - Perfil hidrogeológico 1 (localização Figura 49). 90

Figura 56 - Perfil hidrogeológico 2 (localização Figura 49).

Figura 57 - Classificação química das águas subterrâneas da área de estudo. 


\section{ÍNDICE DE TABELAS}

Tabela 1 - Comparação entre os coeficientes de permeabilidade de algumas rochas e de um maciço rochoso fraturado (QUADROS, 1982).

Tabela 2 - Comparação entre populações de dados de fraturas obtidas em fotografia aérea e no campo.

Tabela 3 - Direções do esforço principal $\sigma_{1}$ em função do número de estruturas observadas.

Tabela 4 - Atividades industriais na área "Passagem Funda" e suas irregularidades. Compilado a partir de PREFEITURA DO MUNICÍPIO DE SÃO PAULO - SECRETARIA MUNICIPAL DO VERDE E DO MEIO AMBIENTE (1996).

Tabela 5 - Valores de vazão e capacidade específica dos poços tubulares.

Tabela 6 - Resultados de erros analíticos obtidos através das diferentes formas de cálculo do balanço iônico em relação às fases de coleta (dados em porcentagem de número de amostras).

Tabela 7 - Condutividades elétricas das águas da área de estudo.

Tabela 8 - Comparação entre as concentrações normais de íons nas águas subterrâneas, segundo CUSTODIO \& LLAMAS (1996), e as concentrações encontradas nas águas da área de estudo.

Tabela 9 - Legislação e regulamentação dos valores máximos permitidos para consumo humano e outros fins. 


\section{RESUMO}

A área de estudo localiza-se na região de Itaquera, zona leste do Município de São Paulo e inclui a área denominada Fazenda do Carmo, na qual estão sendo implantados conjuntos habitacionais da Companhia de Desenvolvimento Habitacional e Urbano do Estado de São Paulo (CDHU), destinados a atender a população de baixa renda. Visto que a população da área é servida apenas parcialmente pela rede pública de abastecimento de água, uma alternativa seria a utilização de água subterrânea, assim, se propôs neste trabalho, fornecer informações acerca das condições hidrogeológicas, principalmente em termos qualitativos, do aqüífero cristalino, no qual está inserida a área, com o objetivo de se conhecer a viabilidade ou não de utilização da água subterrânea pela população que irá ocupar os conjuntos habitacionais da área Fazenda do Carmo.

A metodologia empregada neste estudo envolveu três tipos de levantamento na escala 1:10.000: o levantamento geológico, o levantamento de uso e ocupação da área e o levantamento hidrogeológico. O levantamento geológico incluiu o uso de fotografias aéreas e trabalhos de campo voltados principalmente à caracterização estrutural da área, aplicando-se o método de Angelier para a determinação da direção do esforço máximo principal $\left(\sigma_{1}\right)$ atuante na região, através do qual se pôde determinar as estruturas mais favoráveis à prospecção de água subterrânea na área de estudo. O levantamento de uso e ocupação da área abrangeu o cadastramento de empresas e estabelecimentos existentes e o cadastramento de fontes potenciais de contaminação da água subterrânea, através da interpretação de fotografias aéreas e trabalhos de campo. O levantamento hidrogeológico envolveu o cadastramento de poços e pontos d'água e o levantamento simultâneo de dados relacionados principalmente ao uso da água, à produção dos poços e aos aspectos construtivos e de conservação dos poços, além da análise de parâmetros físico-químicos das águas.

A área de estudo é formada basicamente por rochas cristalinas de idade proterozóica do Grupo Açungui (filitos e xistos) e granitóide intrusivo (granito-gnaisse). A ocorrência da água subterrânea se dá através de dois aqüiferos distintos: o aqüífero poroso (manto de intemperismo e coberturas alóctones) e o aqüifero fraturado (rocha sã fraturada). As águas do aqüifero poroso são explotadas quase exclusivamente por poços cacimbas e o aqüifero fraturado exclusivamente por poços tubulares, sendo usadas predominantemente para atividades industriais, consumo doméstico (incluindo consumo humano) e irrigação. Os filitos e xistos constituem as rochas mais favoráveis ao armazenamento de água na área de 
estudo, as quais desenvolvem um relativamente espesso manto de intemperismo (cerca de 54 metros), que deve estar funcionando como reservatório de água interligado ao aqüifero fraturado. Os poços tubulares perfurados nestas rochas apresentam vazões médias de 4,65 $\mathrm{m}^{3} / \mathrm{h}$. O uso e ocupação da área é de caráter diversificado, porém com predominância dos setores residenciais, comerciais e industriais, aos quais se relacionam diversas atividades potencialmente contaminadoras das águas subterrâneas. O maior problema de contaminação foi evidenciado pelas altas concentrações de nitrato que devem ser provenientes tanto de fossas como dos próprios rios (nos quais os esgotos são lançados diretamente). Esta situação poderá ser controlada com a implantação de rede de saneamento básico, existente, hoje, em apenas alguns locais. Quanto à utilização da água subterrânea pela população da área Fazenda do Carmo, conclui-se que é viavél apenas como fonte complementar de abastecimento. 


\section{ABSTRACT}

The studied area is located in the eastern region of São Paulo city, in the Itaquera neighborhood. In this region the Companhia de Desenvolvimento Habitacional e Urbano do Estado de São Paulo - CDHU (one of the agencies which is in charge of supplying housing for the low income population) has been developing a project to settle more than 3.000 families.

The present thesis is intended to improve the knowledge about the fractured aquifer in the region, to know groundwater feasibility use to supply the new population.

The study, in the 1:10.000 scale included a geological, landuse and qualitative hydrogeological surveys.

The geological survey was focused, mainly, on structural characterization in order to determine the most suitable fracture families for groundwater exploration.

The landuse survey covered industries, commerce and other activities present in the area, as well as the cataloguing of potencial contamination sources.

The hydrogeological survey consisted in the cataloguing of the wells and theirs production, constructive and conservation aspects and physical-chemical characteristics of the water.

The area is formed basically by proterozoic rocks of the Açungui Group (schists and granite-gneiss). It was found that the groundwater occurs either in the porous aquifer (weathering soil and quaternary sediments) or in the fractured aquifer.

The groundwater of the porous aquifer is exploited almost only by excavated wells. Otherwise, the groundwater of the fractured aquifer is exploited by deep wells and is destinated to industrial supply, irrigation and human consumption.

The schists are the most productive rock, due to the relatively thick weathering soil covering (about 58 meters) that should work as a reservoir connected to the fractured aquifer. The deep wells in these rocks presented flows of about $4,65 \mathrm{~m}^{3} / \mathrm{h}$. 
The landuse of the area is diversified but predominates residential, commercial and industrial sectors. These occupations present several potential contaminant activities which might compromise the groundwater quality.

However, the major contaminant problem (high nitrate concentration) was found to be related to the lack of basic sanitary conditions practly in the whole area.

It is suggested that the groundwater might be used as complementary source to attend the population that will be settled in the area. 


\section{1 - INTRODUÇÃO}

\section{1 - Considerações iniciais}

Durante as últimas décadas a utilização das águas subterrâneas da Região Metropolitana de São Paulo (RMSP) vem crescendo de forma acelerada, principalmente para abastecimento industrial/comercial e, secundariamente para auto-consumo doméstico domiciliar ou coletivo, para fins comerciais, abastecimento público de conjuntos habitacionais situados em áreas fora do alcance técnico-econômico da rede de distribuição, ou como reforço de abastecimento de condomínios urbanos (CEPAS, 1994), devido aos baixos custos e a excelente qualidade natural associados às águas subterrâneas.

No final da década de 80, o governo do Estado de São Paulo estabeleceu um Plano de Assentamento Habitacional de 20.000 unidades na RMSP (CDH,1987), destinadas principalmente ao atendimento da população de baixo poder aquisitivo. Dentro deste plano, foi prevista a implantação de mais de 6.000 unidades habitacionais na área denominada "Fazenda do Carmo", localizada na zona leste do Município de São Paulo, de propriedade do governo estadual. Em 1987, a área "Fazenda do Carmo" foi desapropriada pela Companhia de Desenvolvimento Habitacional e Urbano do Estado de São Paulo - CDHU (decreto $n^{\varrho} 26.967$ - 27/04/1987), para a realização dos empreendimentos habitacionais que hoje contabilizam 3.224 unidades construidas e ocupadas, dentre as 7.641 unidades projetadas (SILVA, 2000).

Atualmente, a população que já reside nestes conjuntos é servida pela rede de distribuição de água da SABESP, contudo uma alternativa de suprimento de água para a população que irá habitar estes conjuntos poderia ser a utilização de água subterrânea. Para se verificar a viabilidade ou não de utilização da água subterrânea nesta região são necessários estudos hidrogeológicos, que visem, principalmente, o caráter qualitativo dessas águas, visto que em aqüíferos cristalinos a velocidade de percolação de fluidos pode ser muito alta e assim oferecer um grande risco de contaminação às águas subterrâneas.

Desta forma, se propôs desenvolver o presente trabalho visando fornecer tais informações, incluindo o estudo do uso e ocupação na região quanto ao potencial poluidor. 


\section{2 - Objetivos}

Os principais objetivos desta pesquisa são:

- caracterização do uso e ocupação da área de estudo;

- identificação de eventuais áreas ou fontes que possam oferecer risco à qualidade da água dos poços perfurados na área de estudo;

- avaliação das condições hidrogeológicas em termos qualitativos do aqüifero cristalino;

- proposição de diretrizes de proteção. 


\section{2- ÁREA DE ESTUDO}

\section{1 - Localização e vias de acesso}

A área de estudo situa-se na região de Itaquera, zona leste do Município de São Paulo, distante cerca de $2 \mathrm{~km}$ da divisa com o Município de Ferraz de Vasconcelos. Possui área total de aproximadamente $27,5 \mathrm{~km}^{2}$, sendo que $1,7 \mathrm{~km}^{2}$ desse total pertence à CDHU (Companhia de Desenvolvimento Habitacional e Urbano do Estado de São Paulo) e será referida, neste trabalho, como área Fazenda do Carmo. Esta última possui na sua região central uma Área de Proteção Ambiental - a APA Mata do Iguatemi (decretada pela Lei Estadual $n^{0} 8.284$, de 2 de abril de 1993) (Figura 1).

A área insere-se em quatro folhas topográficas do levantamento aerofotogramétrico realizado por EMPLASA, no Município de São Paulo, em 1993, na escala 1:10.000, articuladas da seguinte forma:

\begin{tabular}{|l|l|} 
Articulação \\
\hline 4313 & 4314 \\
\hline 4315 & 4316 \\
\hline
\end{tabular}

- folha 4313: Cidade Líder;

- folha 4314: Guaianazes;

- folha 4315: São Mateus;

- folha 4316: Rio dos Cochos.

De acordo com o sistema de coordenadas geográficas dessas folhas topográficas, a área de estudo está limitada pelas seguintes coordenadas UTM:

- coordenada 7394500 m (a norte);

- coordenada 7389000 m (a sul);

- coordenada $357000 \mathrm{~m}$ (a leste);

- coordenada $352000 \mathrm{~m}$ (a oeste). 


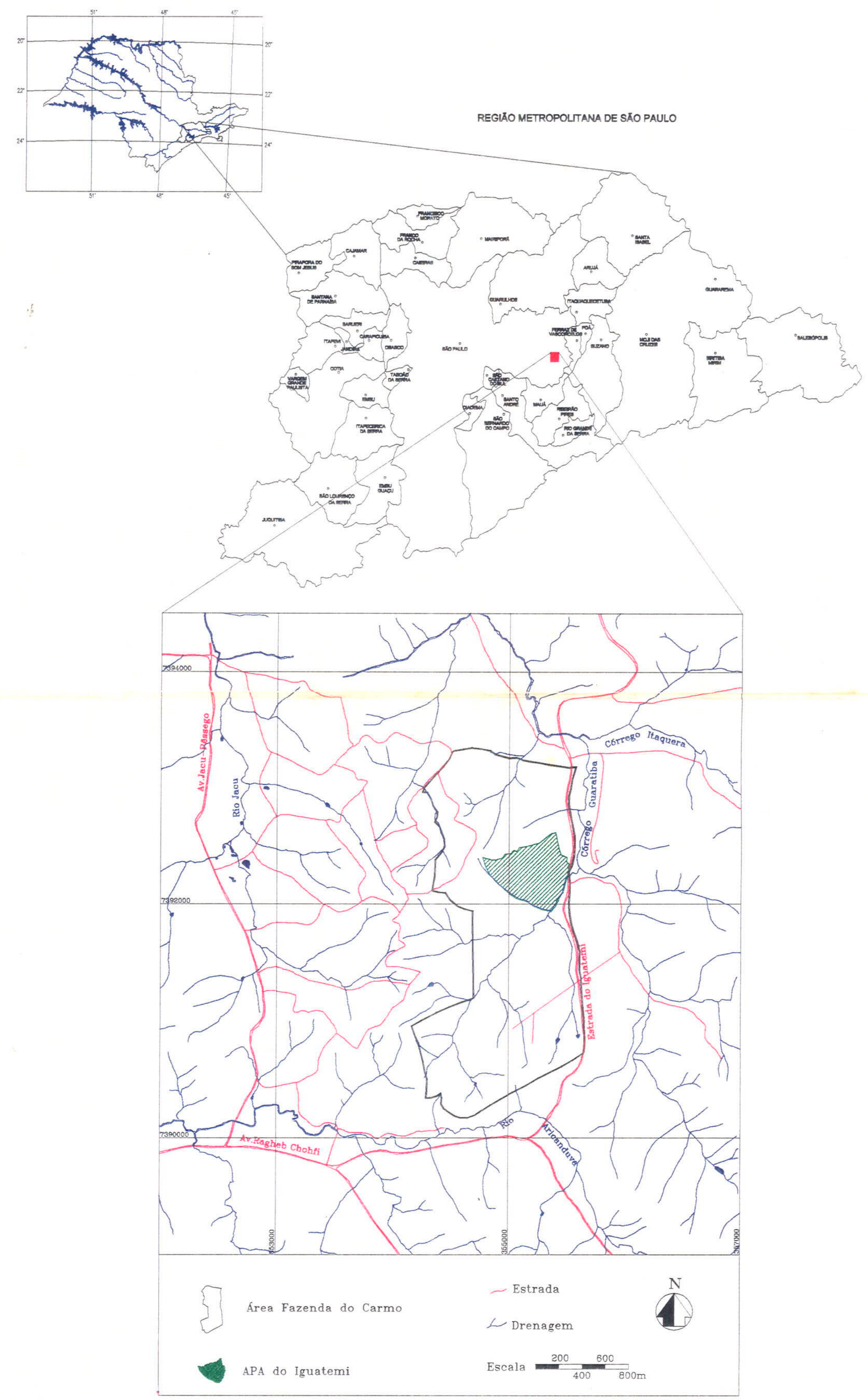

Figura 1 - Localização da área de estudo. 
O sistema viário local é constituído por 3 (três) vias principais: no sentido norte-sul a Estrada do Iguatemi, na porção leste da área, que dá acesso a Guaianazes, a Avenida. JacuPêssego, na extremidade oeste da área, que dá acesso a ltaquera e no sentido leste-oeste a Avenida Ragheb Chohfi, na extremidade sul, ligando as duas estradas anteriores.

\section{2 - Geomorfologia}

De acordo com a divisão geomorfológica do Estado de São Paulo, por ALMEIDA (1964), a RMSP ocupa o compartimento de relevo denominado Planalto Atlântico, zona Planalto Paulistano. O Planalto Paulistano apresenta relevo suavizado de morros e espigões de modesta altura, variando entre 715 e $900 \mathrm{~m}$. É constituído em sua maior parte de filitos, micaxistos, gnaisses, migmatitos de vários tipos e de pequenas intrusões graníticas, além dos sedimentos cenozóicos da Bacia Sedimentar de São Paulo, que se alojam no trecho centronorte do planalto. A origem do Planalto Paulistano está ligada à destruição da superfície Japi (antiga superfície Sul Americana de erosão) e ao estabelecimento, durante o Terciário, da superfície de erosão do Alto Tietê.

Segundo a classificação geomorfológica do IPT (1981a), a área de estudo situa-se no Planalto Attântico, na sub-zona da Morraria do Embu, em terrenos predominantemente cristalinos. A região é caracterizada por relevo de morros (amplitudes entre 100 e $300 \mathrm{~m}$, e declividades médias a altas - acima de 15\%). As elevações possuem topos arredondados e as drenagens são de alta densidade, com vales fechados e planicies aluvionares interiores restritas.

Segundo ROSS \& MOROZ (1997), a área de estudo situa-se na unidade morfoestrutural do Cinturão Orogênico do Atlântico (Planalto Paulistano/Alto Tietê), nas suas porções mais altas. Dentro dessa unidade ocorre ainda a unidade morfoestrutural das Bacias Sedimentares Cenozóicas/Depressões Tectônicas (Planalto São Paulo), representada pelas porções mais baixas, mais próximas ao Rio Tietê. Quanto às formas, ROSS \& MOROZ (1997) descrevem o relevo como formas denudacionais predominantemente convexas, com dimensões interfluviais médias $(750$ a $1.750 \mathrm{~m})$ e grau de entalhamento muito fraco $(<20 \mathrm{~m})$ a fraco $(20 \mathrm{a} 40 \mathrm{~m})$.

Especificamente na área de estudo, o relevo é,bastante acidentado com amplitude altimétrica de até 100 metros. As maiores elevações se verificam nas porções central e 
meridional da área atingindo valores altimétricos superiores a 875 metros (Figura 2). Por outro lado, o relevo da porção setentrional é mais suavizado, abrangendo extensas planícies às margens dos rios principais cujas altitudes são iguais ou inferiores a 775 metros (Figura 2). A drenagem apresenta densidade média a alta, sendo um pouco mais baixa na porção setentrional da área, e o padrão é dendrítico a localmente radial, com canais orientados preferencialmente nas direções NE-SW e NW-SE. A forma das encostas é convexa a côncavaretilinea-convexa e as declividades atingem valores superiores a $70 \%$, porém predominam as inferiores a $30 \%$ (Figura 3).

\section{3 - Hidrografia}

A maior parte da RMSP, cerca de $70 \%$, se identifica com a bacia hidrográfica do Alto Tietê, que é a mais importante das bacias hidrográficas da RMSP, não só pela sua extensão geográfica (5.550 $\mathrm{km}^{2}$ na RMSP), mas sobretudo pelo inter-relacionamento de seus rios com a complexa malha urbana, e também porque grande parte da água utilizada ou a ser utilizada para o abastecimento da metrópole origina-se de seus reservatórios existentes ou planejados.

Devido à importância desta bacia para o abastecimento da RMSP grande parte dela está protegida pela Legislação de Proteção aos Mananciais. A aproximadamente $2 \mathrm{~km}$ da área de estudo, situa-se o limite da Área de Proteção aos Mananciais que coincide com o divisor de águas da Bacia do Ribeirão Guaió, na divisa do Município de São Paulo com o Município de Ferraz de Vasconcelos.

A rede hidrográfica da bacia do Alto Tietê é constituida pelo Rio Tietê e seus afluentes, dos quais se destacam os rios Paraitinga, Baquirivu-Guaçu, Cabuçu de Cima e Juqueri (margem direita) e os rios Claro, Biritiba Mirim, Jundiai, Taiaçupeba, Guaió, Aricanduva, Tamanduaté, Pinheiros, Cotia e São João do Barueri (margem esquerda). Dentre suas subbacias, destacam-se aqui, as do Rio Itaquera, Rio Verde e Rio Aricanduva, nas quais está inserida a área de estudo (Figura 4). Os principais rios que drenam a área são: o Rio Aricanduva (extremo sul da área), Rio Jacu (oeste da área), Córrego ltaquera e Córrego Guaratiba (leste da área) (Figura 1). 


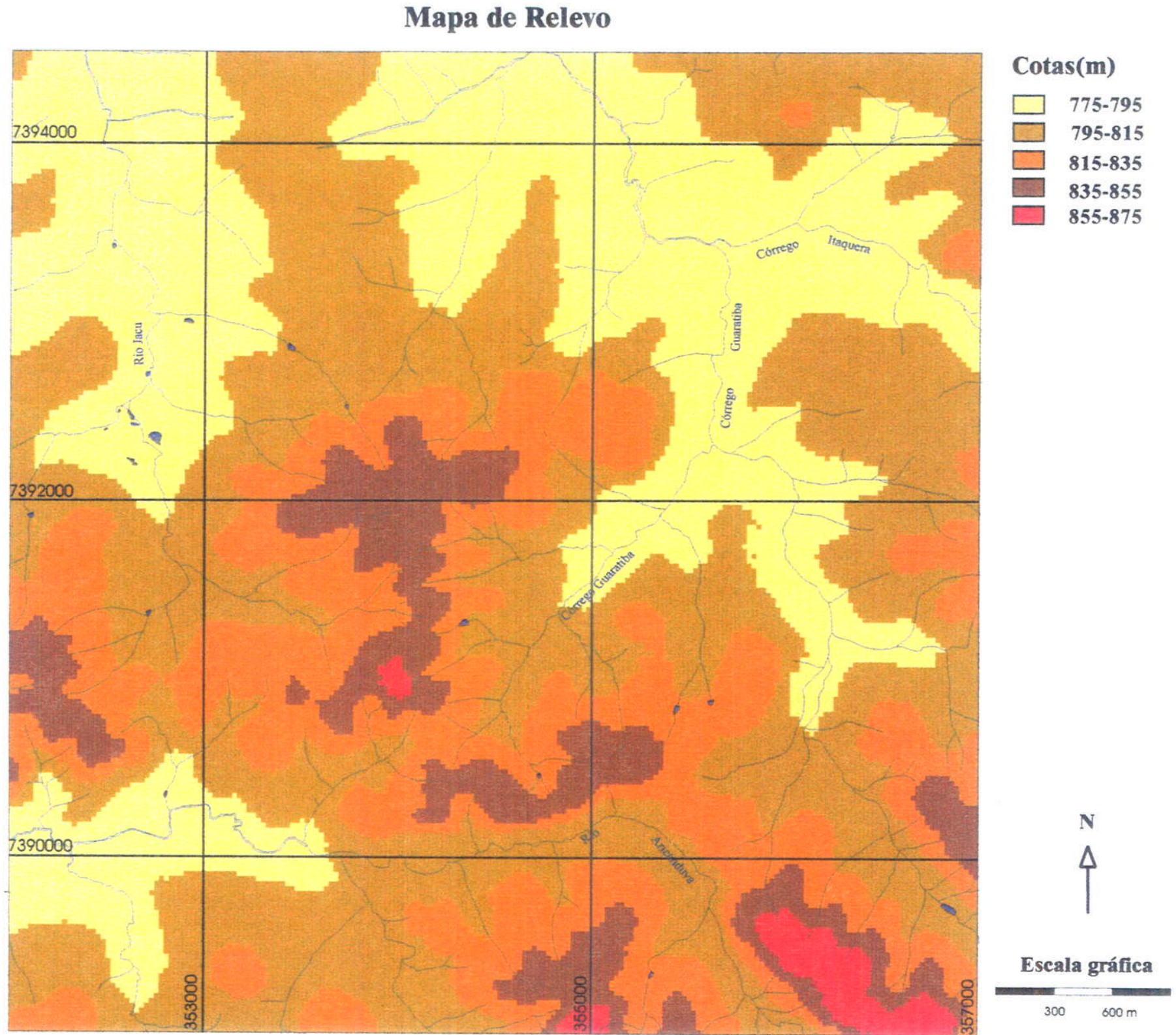

Figura 2 - Mapa de relevo da área de estudo. 
Mapa de Declividade

Classes de Declividade $(\%)$

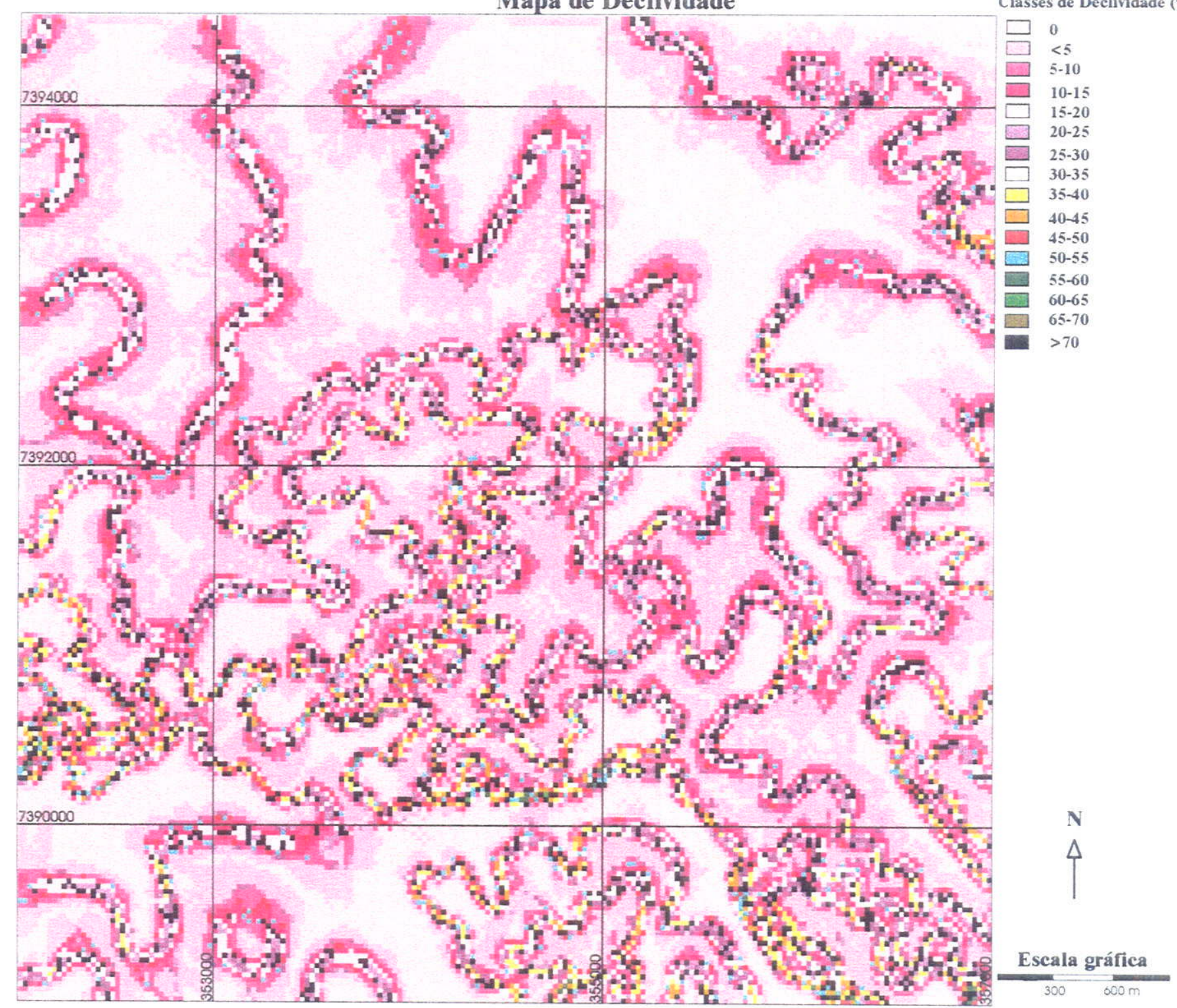

Figura 3 - Mapa de declividade da área de estudo. 


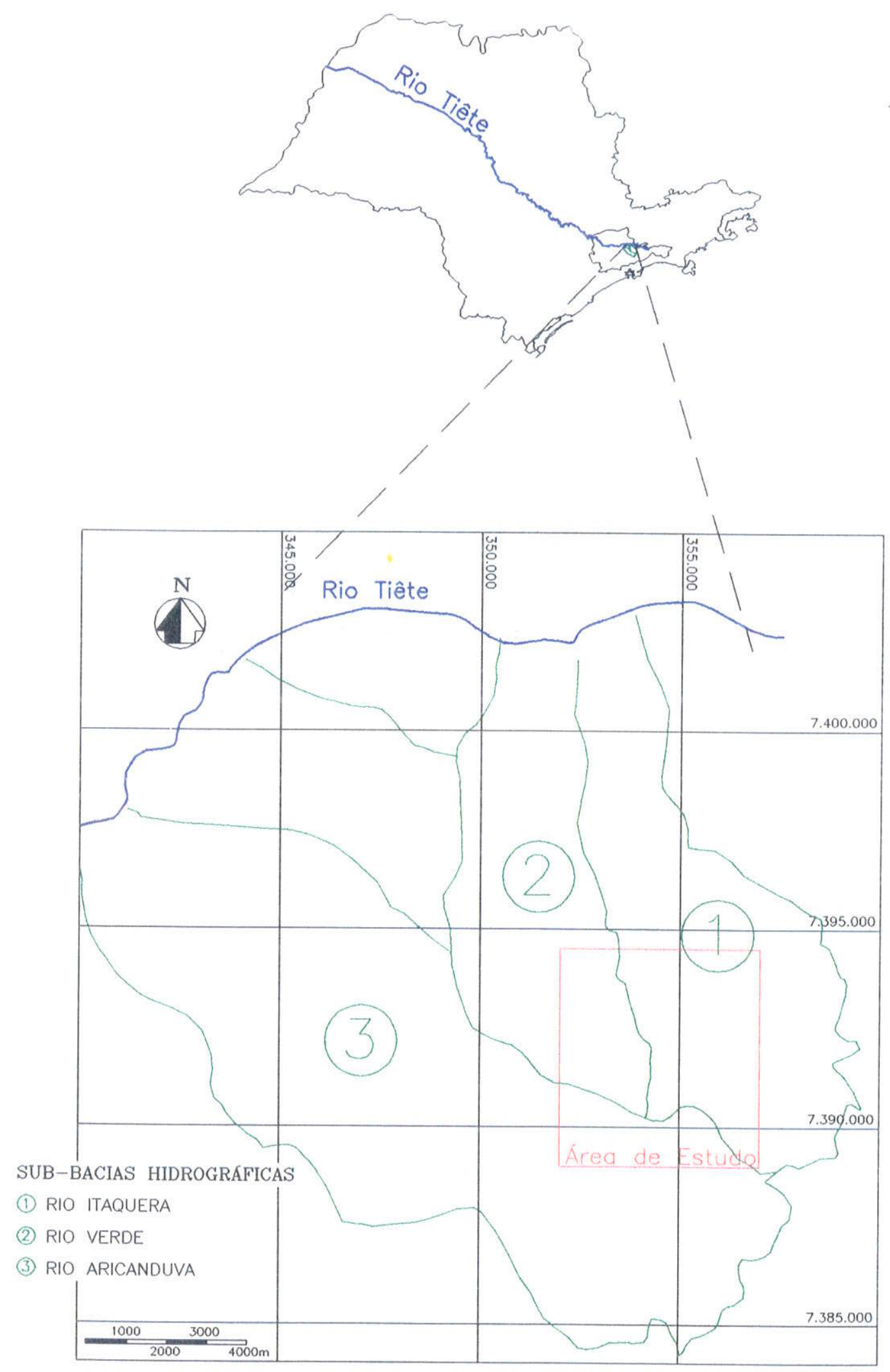

Figura 4 - Sub-bacias hidrográficas da área de estudo e suas localizações na Bacia do Alto Tietê. 


\section{4 - Clima}

O clima da RMSP é do tipo tropical temperado de altitude, com temperatura média anual oscilando em torno de $25^{\circ} \mathrm{C}$. As médias mensais atingem seus valores mínimos, inferiores a $23^{\circ} \mathrm{C}$, nos meses de maio a agosto, sendo julho o de mais baixa temperatura $\left(12-14^{\circ} \mathrm{C}\right)$. As médias mensais mais elevadas, superiores a $27^{\circ} \mathrm{C}$, ocorrem no periodo de novembro a março, atingindo valores máximos em fevereiro.

O regime de chuvas é caracterizado por dois periodos nítidos de distribuição mensal: um período mais chuvoso, com $60-70 \%$ do total anual, se estendendo de outubro a março, e o mais seco que vai de abril a setembro. As médias mensais do período chuvoso variam entre 112 e $533 \mathrm{~mm}$, enquanto os valores mensais do periodo seco situam-se entre 40 e $343 \mathrm{~mm}$ (DAEE, 1975).

$\mathrm{Na}$ região de Itaquera, os dados obtidos das estações pluviométricas Posto Itaquera e Posto Guaianazes, no periodo de 1995 a 1998, revelam médias mensais de outubro a março entre 103,8 e 298, $6 \mathrm{~mm}$ e médias mensais de abril a setembro entre 14,45 e $110,8 \mathrm{~mm}$. As médias anuais neste periodo variaram entre 1378,75 e 1532,60 mm, correspondendo ao Posto Itaquera e Posto Guaianazes, respectivamente.

A distribuição dos indices mensais neste período são apresentadas na Figura 5 , incluindo o ano de 1999, de janeiro a abril.

\section{5 - Histórico de uso e ocupação}

O histórico de uso e ocupação dos subúrbios orientais da cidade de São Paulo até a década de 40 foi estudado por AZEVEDO (1945), sendo que aqui é apresentada uma sintese desse estudo.

Na década de 40, a ocupação da região de Itaquera era caracterizada pela existência de pequenos povoados e vilas próximos à estrada de ferro "Central do Brasil" (R.F.F.S.A.), onde se destacavam dois núcleos: Itaquera e Lajeado (atualmente Guaianazes). 

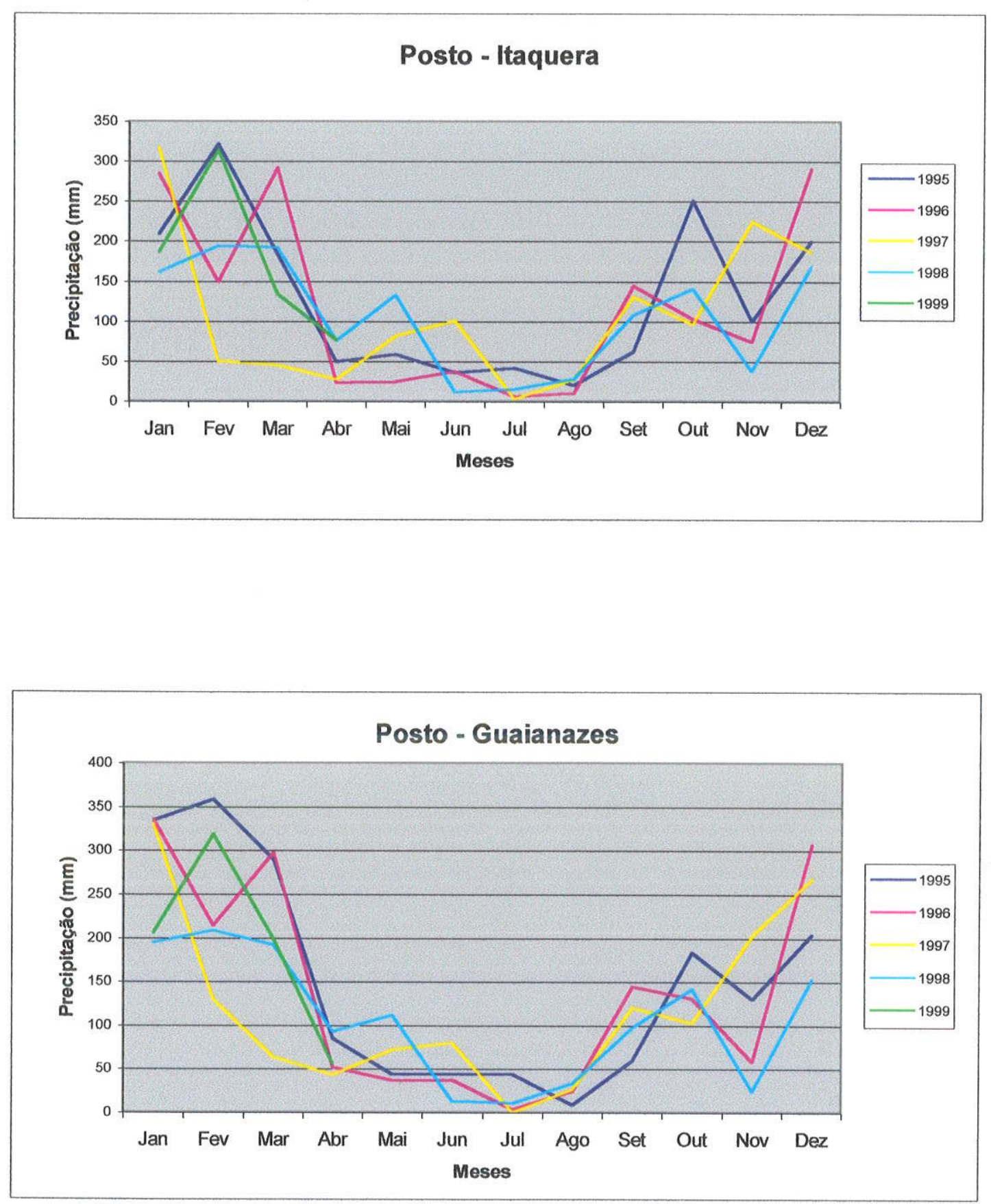

Figura 5 - Distribuições mensais das chuvas na região de Itaquera, no período de 1995 a 1999. 
Em 1945, a população que vivia na região de Itaquera era calculada em 12 mil habitantes, sendo formada, na sua maioria, por brasileiros com uma participação de $15 \%$ do total de japoneses, que se dedicavam às atividades rurais.

O desenvolvimento de Itaquera, deve-se, até certo ponto, ao crescimento da capital paulista, pois foi sentindo a futura expansão da metrópole que a "Companhia Comercial, Pastoril e Agrícola" adquiriu, em 1919, os terrenos situados entre os rios Verde e Jacu, iniciando-se, assim, o loteamento de terras na região.

A sul desses terrenos, terras que pertenceram a uma antiga fazenda (Fazenda Caaguaçu) foi dividida em mais de 600 lotes de terras, a partir dos quais se processou o povoamento, surgindo os primeiros sitios. Povos de diferentes nacionalidades (brasileiros, japoneses, alemães, russos, lituanos, checoslovacos e poloneses) se fixaram neste centro de povoamento chamado "Colônia", porém principalmente os japoneses que foram encaminhados para lá pelo governo, a partir de 1922.

Do ponto de vista econômico, a "Colônia" teve grande importância não só para a região de Itaquera como, principalmente, para a própria capital paulista, tendo sido considerada o mais importante centro agricola da região naquela época. Suas culturas eram classificadas como intensivas, embora reduzido fosse o instrumental empregado. Os morangos mereciam a preferência dos hortelães nipônicos; mas também eram cultivados uvas, pêssegos, ameixas amarelas do Japão, ameixas pretas, limões sicilianos, caquis, pêras, laranjas, etc. Ao seu lado, apareciam as culturas de tomates, aspargos, alcachofras, couves-flores, alfaces, cenouras, repolhos, batatinhas, etc. Esse centro agrícola ainda se dedicava à produção, em larga escala, de ovos de granja.

Por intermédio de organizações cooperativistas (notadamente a "Cooperativa Agrícola de Cotia" e a "Sociedade Cooperativa Agricola Suburbana da Capital"), toda a produção era encaminhada para o mercado e para as feiras da metrópole paulistana.

Fora da "Colônia", destacavam-se alguns locais isolados de atividades agrícolas importantes com culturas variadas de frutas, cana e milho, além de plantação de vinhedos e oliveiras, na região do Lajeado.

No mais, cabia lembrar apenas as pequenas áreas cultivadas para uso dos próprios moradores, bastante comuns em toda a região, sem grande valor do ponto de vista da 
economia regional, mas importantes por satisfazerem uma parte do consumo individual dos habitantes das diversas "vilas". Restringiam-se às encostas das colinas e dos morros, fugindo quase sempre das partes mais elevadas (muito "lavadas" pelas enxurradas) e do fundo dos vales, brejosos, na maioria das vezes.

Um dos problemas existentes na região era o de água. A água era obtida em poços, que chegavam a ter até 20 metros de profundidade, sendo retirada muitas vezes por meio de bombas acionadas pelo vento, o que acabava por dar à vila uma fisionomia própria, em virtude do elevado número de seus moinhos de vento. Outro problema era a falta de energia elétrica que impossibilitava, dentre outras coisas, a instalação de indústrias importantes, podendo citarse apenas uma fábrica em toda a região de Itaquera até 1945: a pequena Fábrica de Fitas Dora.

A exploração do subsolo era feita através de algumas olarias, situadas principalmente nas vizinhanças de Lajeado, que extraiam o solo argiloso das várzeas para a fabricação de tijolos e, de pedreiras de granito localizadas tanto em Itaquera como em Lajeado, que forneciam granito para a capital paulistana para uso na construção civil.

Em contrapartida, atualmente a região de Itaquera e Guaianazes abriga um grande contingente populacional que vem crescendo constantemente, principalmente devido ao desenvolvimento econômico da região, a partir do estabelecimento de muitas indústrias e centros comerciais importantes que geraram mais empregos para a população local. Com o crescimento populacional surgiram muitos conjuntos habitacionais populares (da COHAB e da $\mathrm{CDHU}$ ) que abrigam hoje uma população estimada em cerca de 100.000 habitantes.

Apesar do crescimento industrial, especificamente na área de estudo, muitos ainda dedicam-se às atividades agrícolas (basicamente os japoneses) em pequenas chácaras e sitios, onde cultivam verduras (hidroponia), frutas, café, flores e plantas ornamentais, para consumo de subsistência mas também para comercialização.

O abastecimento de água ainda constitui um problema, pois muitos não são servidos pela rede de água da SABESP, o que leva a população e as indústrias a se utilizar da água subterrânea através de poços cacimbas (poços escavados) e tubulares. O principal problema no caso das cacimbas está relacionado com a qualidade das águas, algumas vezes impróprias para consumo humano e até para outras atividades devido a contaminações decorrentes de 
atividades antrópicas desenvolvidas na superfície e da má construção e conservação dos poços. No caso dos poços tubulares, o principal problema enfrentado é o das baixas produções dos poços devido à má qualidade dos aqüíferos em termos de armazenamento de água.

Quanto às atividades mineiras, ainda hoje se explotam o "granito" das pedreiras de Itaquera (pedreiras Lajeado) para a produção de pedra britada e também a extração do solo argiloso, em olarias locais, para a fabricação de tijolos. 


\section{3 - REVISÃO BIBLIOGRÁFICA}

\section{1 - Quadro geológico regional}

\subsection{1 - Aspectos litoestratigráficos}

A maior parte da área urbana da Região Metropolitana de São Paulo (RMSP) está assentada sobre terrenos sedimentares de idade cenozóica, compreendendo os depósitos terciários da Bacia Sedimentar de São Paulo e as coberturas aluviais mais recentes, de idade quaternária, desenvolvidas ao longo dos principais rios que drenam a região. Os terrenos cristalinos, por sua vez, contornam as áreas sedimentares e configuram, praticamente, toda a borda da RMSP, abrangendo significativa extensão.

Nos terrenos cristalinos da RMSP afloram essencialmente duas unidades geológicas, proterozóicas, separadas pelas falhas de Taxaquara e do Rio Jaguari, além das rochas granitóides intrusivas. O conjunto situado a sul destas falhas é representado pelo Grupo Açungui, subdividido por HASUI (1975a) em Complexo Ectinítico Pilar e Complexo Migmatítico Embu, com base em critérios puramente litológicos, e o conjunto situado a norte das falhas é representado pelo Grupo São Roque (COUTINHO, 1972), subdividido posteriormente, em Grupo São Roque e Grupo Serra do Itaberaba, por JUL.IANI et al. (1986).

Em termos litológicos o Grupo São Roque é formado por uma seqüência metassedimentar ectinitica composta por metassedimentos de origem clástica (metaconglomerados, meta-arcósios e metagrauvacas, quartzitos, filitos e mica-xistos) associados a metabasitos e rochas granitóides intrusivas tardi-tectônicas (COUTINHO, 1972). O Grupo Açungui é constituido por ectinitos similares aos do Grupo São Roque, representando o Complexo Pilar, e por migmatitos estromatíticos, representando o Complexo Embu, ambos com associação de metabasitos e penetrados por vários corpos granitóides sintectônicos e pós-tectônicos (HASUI, 1975a).

Trabalhos realizados sobre o embasamento cristalino no leste paulista (FERNANDES, 1991; SANTORO et al., 1991; GIMENEZ FILHO et al., 1991; THEODOROVICZ et al., 1991) tem abandonado a denominação Complexo Pilar, considerando, desta forma, os metassedimentos como do Complexo Embu.

HASUI \& SADOWSKI (1976) reconheceram que no Grupo São Roque e no Complexo Pilar, o metamorfismo regional se deu em fácies xisto verde a anfibolito, enquanto no Complexo Embu o metamorfismo se deu em fácies anfibolito, sendo também similares as 
histórias metamórficas dos grupos São Roque e Açungui, conforme descritas por HASUI (1975a). Segundo COUTINHO (1972), a passagem transicional entre os litotipos do Complexo Pilar para os do Complexo Embu é dada pela feldspatização progressiva dos ectinitos de fácies xisto verde para as rochas gnáissico migmatíticas da fácies anfibolito, respectivamente. Este fato também foi verificado nas rochas do Complexo Embu, na porção leste de São Paulo, por SANTORO et al. (1991), que relatam a passagem gradual de micaxistos e gnaisses para migmatitos.

Os metassedimentos mais comuns do Complexo Pilar são os xistos, que variam entre quartzo-mica xistos, biotita-quartzo xistos, granada-biotita xistos, xistos grafitosos, clorita xistos, sericita-biotita xistos, talco xistos, magnetita xistos e calcoxistos, ocorrendo intercalações subordinadas de filitos, metassiltitos, quartzitos, mármores e calcossilicáticas (IPT, 1981b).

HASUl (1975b) ao caracterizar a geologia da folha de São Roque, descreve os migmatitos do Complexo Embu como possuindo dominantemente estrutura estromatítica em que o paleossoma representado por gnaisses, micaxistos e quartzo-xistos é, em geral, a parte mais destacada. Intercalados aos xistos aparecem leitos de quartzito, corpos de rochas calcosilicatadas e metabasitos. O neossoma, por sua vez, possuí composição granítica a granodioritica, granulação variável (fina a grossa) e forma faixas, boisões e lentes com espessuras de milimetricas a métricas, concordantes com a xistosidade do paleossoma. Na região de São Paulo, esses migmatitos foram registrados como gnaisses $\mathrm{e}$ xistos, por COUTINHO (1972).

Os metabasitos presentes tanto no Grupo São Roque como no Grupo Açungui são corpos de rochas básicas geradas durante magmatismo prémtectônico que foram transformadas pelo metamorfismo regional em fácies xisto verde (HASUI, 1975a). São constituídos, dentre outros minerais, por actinolita-tremolita, clorita, minerais do grupo do epidoto, quartzo, calcita, titanita e biotita. São ora concordantes com a estratificação reliquiar dos metassedimentos, ora discordantes, com espessura e extensões restritas, com exceção dos corpos de Alumínio e Pirapora, que alcançam várias centenas de metros.

As rochas granitóides que afloram nas proximidades da RMSP possuem dimensões variadas de batólitos a pequenos "stocks", estando alguns recobertos pelos sedimentos da Bacia Sedimentar de São Paulo. Estas rochas apresentam indícios de cataciase generalizados, em grande parte atribuiveis a falhamentos posteriores relacionados com a evolução tectônica (HASUI, 1975a). Segundo JULIANI (1992), dentre os granitóides da RMSP predominam amplamente a fácies Cantareira, tanto no Complexo Embu como nos 
grupos São Roque e Serra do Itaberaba. Os corpos graníticos da fácies Cantareira apresentam caráter alóctone e parautóctone, com feições de contato tanto transicionais quanto parcialmente discordantes, desenvolvendo inclusive algumas auréolas de contato quando intrudidos em metamorfitos de baixo grau. São observados também, tipos bastante diversificados textural, composicional e mineralogicamente. O tipo granito-gnáissico é o mais comum, com a foliação concordante ao trend regional. Possui uma granulação fina a média, composição granítica a granodioritica e ocorrência conspícua de megacristais de feldspato potássico, oriundos de uma metassomatose tardia, conferindo à rocha caráter porfiróide (IPT, 1981b).

A Bacia Sedimentar de São Paulo está assentada quase que exclusivamente sobre o Grupo Açungui. Segundo a concepção de RICCOMINI (1989), os depósitos sedimentares continentais terciários da Bacia de São Paulo compreendem uma seqüência basal, com as formações Resende, Tremembé e São Paulo, reunidas no Grụpo Taubaté, recoberta, de forma presumivelmente discordante, pela Formação Itaquaquecetuba.

As unidades quaternárias, na RMSP, correspondem às extensas planícies aluviais associadas aos principais rios da região (Tietê, Pinheiros e Tamanduatei), presentes também ao longo das drenagens de menor porte. Segundo MELO et al. (1987), os depósitos pleistocênicos compreendem predominantemente colúvios argilo-arenosos, com lentes mais argilosas ou conglomératicas, ocasionalmente exibindo madeira fóssil, e aluviōes subordinados constituídos por conglomerados basais sobrepostos por areias grossas e conglomeráticas com estratificações cruzadas, gradando para areias finas a médias, com porções de argilas arenosas, podendo ocorrer também fragmentos de madeira fóssil nesses dois últimos pacotes.

\subsection{2 - Aspectos tectônicos e estruturais}

As mais destacadas feições estruturais no precambriano paulista são as falhas transcorrentes (IPT, 1981b), subverticais, orientadas nas direções ENE a EW (Figura 6). Segundo HASUI \& SADOWSKI (1976), o sistema de falhamentos transcorrentes se relaciona com a evolução do Ciclo Brasiliano, tendo começado a se desenvolver após o metamorfismo regional e se manifestado até após o magmatismo pós-tectônico, ou seja, até a estabilização da plataforma (esta se deu antes do Siluriano). Durante o Cenozóico estas falhas foram reativadas em diversas ocasiões, como observado por RICCOMINI (1989), imprimindo deformações também nos sedimentos cenozóicos. 


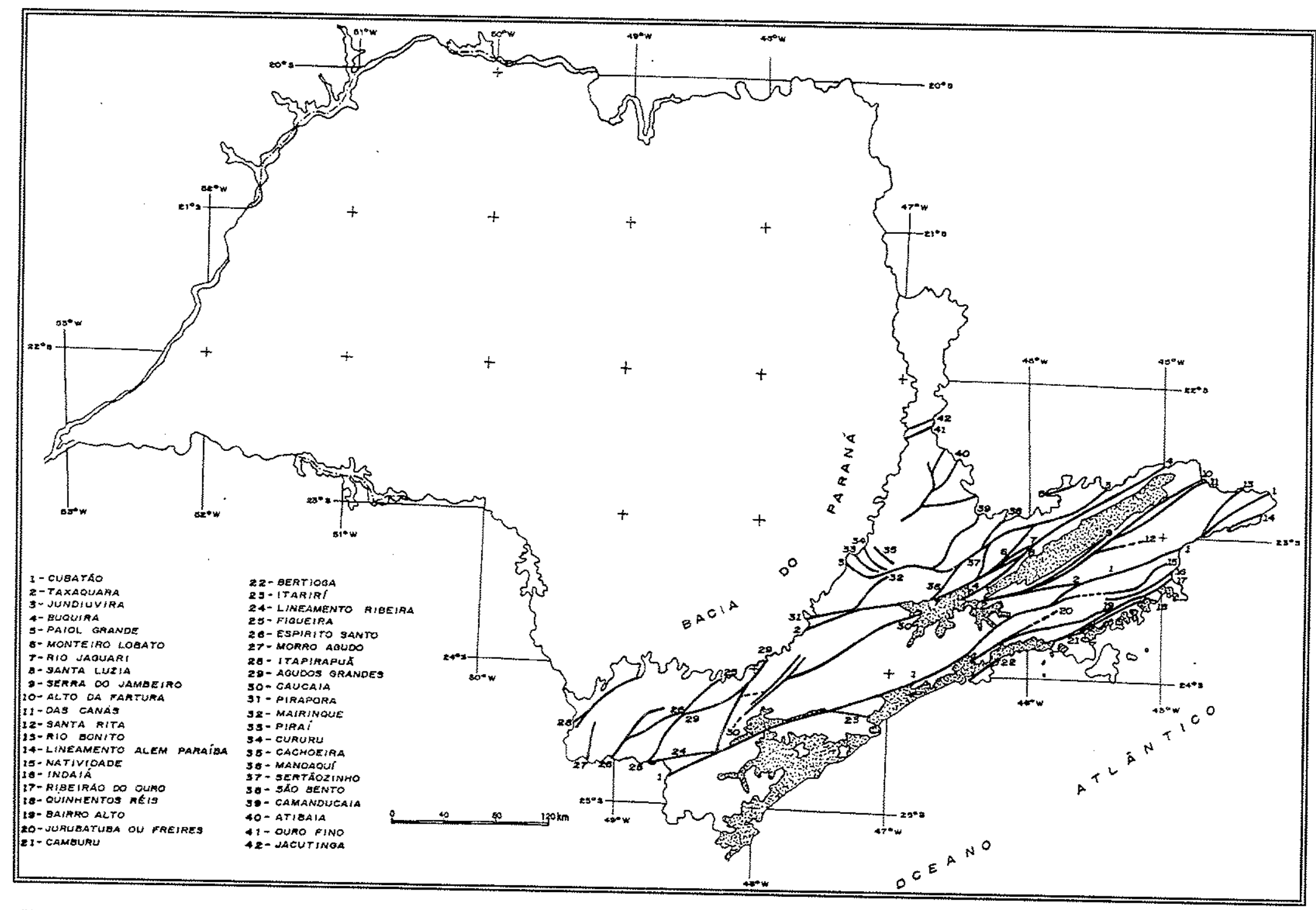

Figura 6 - Principais falhamentos transcorrentes do embasamento cristalino do Estado de São Paulo (IPT, 1981b). 
Em termos regionais as falhas formam feixes que definem enormes faixas de cisalhamento, com 1 (um) a 4 (quatro) quilômetros de largura e que se estendem por dezenas de quilômetros (THEODOROVICZ et al., 1991). Nelas se reconhecem uma importante foliação milonitica freqüentemente verticalizada com lineações de estiramento mineral horizontais (THEODOROVICZ et al., 1991), além de estrias subverticais de ocorrência local, indicando soerguimento e abatimento de blocos (HASUI, 1975b; GIMENEZ FILHO et al., 1991). A deformação nestas faixas é de natureza predominantemente dextral e dúctil (THEODOROVICZ et al., 1991; GIMENEZ FlLHO et al., 1991), esta última evidenciada pelo desenvolvimento extensivo de proto a ultramilonitos. Estruturas rúpteis podem ser vistas localmente, indicando movimentação nos estágios finais de desenvolvimento das faixas, ou mesmo reativações posteriores (GIMENEZ FILHO et al., 1991). Dentre as estruturas rúpteis menores são citadas, por HASUl (1975b), 4 (quatro) a 5 (cinco) sistemas de juntas bem desenvolvidos nas rochas metamórficas e granitóides dos grupos São Roque e Açungui, na folha de São Roque.

Além das falhas, algumas estruturas anticlinoriais e sinclinoriais foram reconhecidas nos domínios dos grupos São Roque e Açungui no Estado de São Paulo, sendo destacada aqui a sinclinal de Itaquera, localizada nas proximidades da área de estudo, descrita por COUTINHO (1972). Segundo este autor, a sinclinal tem como feição singular a presença de gnaisse ocupando parte de seu núcleo. A origem dessa rocha no interior de tal estrutura foi explicada, nesta ocasião, como sendo por processo de granitização agindo sobre metassedimentos.

Na região sudeste do Estado de São Paulo, (HASUI \& SADOWSKI, 1976) mostraram envolvimento do Grupo Açungui (tanto do Complexo Pilar quanto do Complexo Embu) em duas fases de dobramentos (sucedidos por crenulação), sendo a última fase responsável pela direção geral ENE da xistosidade do Grupo Açungui, que é paralela à estratificação reliquiar. $O$ fato da xistosidade ser paralela à estratificação reliquiar indica que o Complexo Embu fol afetado por uma fase anterior de dobramento. As dobras geradas na segunda fase de deformação são cerradas (ocasionalmente fechadas e isoclinais), com planos axiais subverticais.

Numa área mais extensa abrangendo o precambriano de São Paulo e do Paraná, HASUl et al. (1980) reconheceu basicamente 3 (três) fases de dobramentos no Grupo Açungui, sendo que as duas primeiras são correlacionáveis às de HASUI \& SADOWSKI (1976) no sudeste paulista. Na terceira fase se desenvolveram dobras de portes variados, associadas a intrusões granitóides, falhas e crenulação, de incidência local. 
No leste paulista, FERNANDES (1991) descreve 5 (cinco) fases de dobramentos nas rochas do Complexo Embu, correlacionável ao Grupo Açungui de HASUI \& SADOWSKI (1976). As dobras geradas nas duas primeiras fases correspondem àquelas duas primeiras descritas nos dois trabalhos anteriores e, segundo FERNANDES (1991), apresentam o mesmo tipo de metamorfismo. As dobras geradas na $3^{\text {a }}$ fase são inversas, apertadas, centimétricas a hectométricas e são acompanhadas por retrometamorfismo generalizado. $\mathrm{Na} 4^{\text {a }}$ fase se formaram dobras abertas a fechadas, normais, isópacas, centimétricas a quilométricas correspondendo aos sinformes e antiformes normais presentes na área. A $5^{\mathrm{a}}$ fase, pós metamórfica, produziu ondulações amplas ou corrugações centimétricas com eixos caindo para NW ou SE.

As dobras do Grupo São Roque, segundo HASUI \& SADOWSKI (1976), apresentam estilo geral semelhante às do Grupo Açungui, o que pode ser atribuido a uma fase de deformação em comum, porém se diferenciam por exibirem xistosidade plano axial. Para HASUI (1975b) em ambos os grupos o dobramento principal ( $2^{\text {a }}$ fase no Grupo Açungui e $1^{\text {a }}$ fase no Grupo São Roque) ocorreu contemporaneamente ao metamorfismo regional. Assim como no Grupo Açungui, as rochas do Grupo São Roque (tanto os metapelitos quanto os migmatitos) foram submetidas aos processos de crenulação e transposição, já em condições de rigidez (HASUI, 1975a e b).

\subsection{3 - Evolução tectônica cenozóica}

As estruturas de reativação, condicionantes do embaciamento da Bacia de São Paulo e responsáveis pelas deformações posteriores nos sedimentos, correspondem a falhamentos segundo as direções estruturais ENE a EW, NNE, NNW e WNW, padrão este análogo ao das bacias situadas a leste (bacias de Taubaté, Resende e Volta Redonda) (RICCOMINI et al., 1992). Segundo os mesmos autores estas falhas apresentam ora movimentação predominantemente normal ou reversa, ora componente essencialmente direcional, dextral ou sinistral, bem como situações intermediárias. Além dessas estruturas, estes autores relatam falhas de empurrão, dobras e juntas em escala mesoscópica.

Segundo RICCOMINI (1989), as diferentes movimentações ao longo dos falhamentos não podem ser explicadas por um único regime de esforços, sendo necessário a superposição de movimentações, numa determinada seqüência cronológica. Assim, ao estudar as bacias continentais terciárias do sudeste do Brasil o autor propôs um modelo de evolução, que contempla as seguintes fases: 
a. formação da depressão original (hemi-gráben) no Paleógeno (Eoceno-Oligoceno) como resultado da reativação de antigas zonas de cisalhamento pelo campo de esforços extensionais de direção NNW-SSE, imposto pelo basculamento termomecânico da Bacia de Santos;

b. modificação do regime de esforços (Neógeno: Mioceno) - extensão NW-SE e compressão local NE-SW, relacionados a um binário transcorrente sinistral orientado segundo E-W;

c. fase de estabilização tectônica (Pleistoceno Inferior) seguida de nova fase transcorrente, com compressão NW-SE e extensão NE-SW relacionada a um binário dextral;

d. vigência de regime extensional, de direção NW(WNW)-SE(ESE) - no Holoceno. Falhamentos normais;

e. o campo de tensões deduzido para as movimentações pliocênicas e mais recentes indica compressão, mostrando, portanto, nova mudança no regime de esforços.

Para RICCOMINI (1989) o modelo que melhor contemplaria os esforços compressivos NE-SW e NW-SE seria o trancorrente, com binário principal orientado segundo a direção aproximada E.W, inicialmente sinistral e, posteriormente dextral. Da mesma forma, RICCOMINI (1995) ao estudar a tectônica e as deformações nos depósitos sedimentares pós-gondvânicos da Bacia do Paraná em São Paulo reconhece que, de maneira geral, o Cenozóico permanece associado a um campo de tensões relacionado a um binário dextral de direção próxima a E-W, com compressão regional (tensão máxima na direção NW-SE), com breves alternâncias para trancorrência sinistral de mesma direção (tensão máxima na direção NE-SW), em função do balanço da taxa de abertura na Cadeia Meso Atlântica e de subducção da Placa de Nazca sob a Sul-Americana. O último evento tectônico citado por este autor, indica compressão na direção E-W, o que se harmoniza com a direção da tensão horizontal máxima de toda a parte continental brasileira obtida por ASSUMPÇÃO (1998), em estudo de sismotectônica, utilizando dados de mecanismos focais e "breakouts", que revelou ser mais ou menos a direção $\mathrm{E}-\mathrm{W}$. 


\section{2 - Geologia local}

Dentre os trabalhos de mapeamento, em escalas regionais, que abrangem a área de estudo, destacam-se o de COUTINHO (1972) - 1:100.000, EMPLASA (1980) - 1:100.000, IPT (1981b) - 1:500.000 e CEPAS (1994) - 1:50.000 (folha Mauá) - Figura 7, sendo este último, um trabalho de compilação de diversos trabalhos anteriores, acrescido de informações de inúmeros relatórios técnicos e da experiência pessoal de seus autores.

Como o relatório de CEPAS (1994) não traz a descrição das unidades litológicas proterozóicas, apenas das terciárias e quaternárias, serão feitas aqui apenas algumas considerações referentes à Figura 7.

A unidade designada pela sigla PEf corresponde aos filitos e xistos correlacionável ao Complexo Pilar (Grupo Açungui), descrito em IPT(1981b). Intercalados aos filitos, aparecem os anfibolitos $(\mathrm{PEa})$, presentes em forma de cunha de rocha delimitada parcialmente por falhas. A unidade PEq constitui uma variação da unidade (PEf) e é composta predominantemente por quartzitos, com ocorrências subordinadas de metassiltitos e xistos.

Quanto aos granitóides (unidade PEgo), incluem aqui porções gnáissicas, migmatiticas e blastomiloniticas subordinadas, sugerindo se basear em EMPLASA (1980), que associa estas rochas ao Complexo Embu (Grupo Açungui). Muitos desses granitóides foram mapeados como gnaisses, na região da Grande São Paulo, por COUTINHO (1972), que atribuiu parte dos paragnaisses ao Complexo Embu. Por outro lado, no mapa de IPT (1981b) esses granitóides foram mapeados como granitos sintectônicos (fácies Cantareira), conforme descritos no item 3.1.1. THEODOROVICZ et al. (1991) ao mapearem a folha Mauá denominaram essas rochas de granito-gnaisses de Itaquera, por isso essa será a denominação adotada no presente trabatho.

Os sedimentos terciários pertencentes à Bacia Sedimentar de São Paulo estão representados basicamente pela Formação Resende (unidade Orl, Orf), porém não afloram na área de abrangência do mapa (Figura 7).

As unidades quaternárias (Qa) são descritas segundo MELO et al. (1987) conforme já apresentadas no item 3.1.1. 


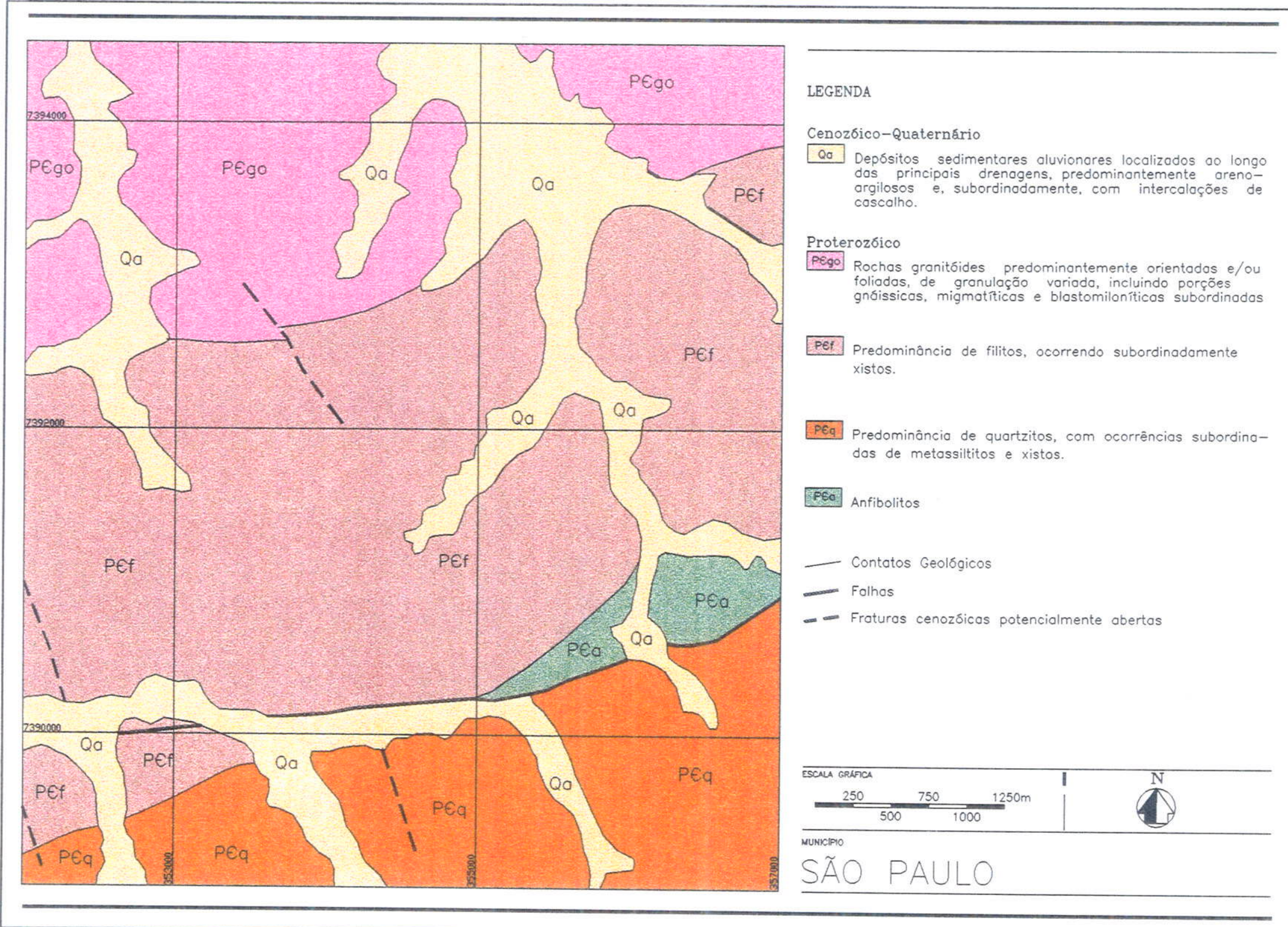

Figura 7 - Mapa geológico da folha Mauá - parcial (CEPAS, 1994). 


\section{3 - Análise cinemático-estrutural}

\subsection{1 - Determinação da direção e sentido do movimento em falhas rúpteis}

Existem vários métodos que se ocupam do estudo de tensões aplicadas a populações de falhas (CARNEIRO, 1996), contudo, serão citados aqui apenas os dois métodos mais usados: o método Arthaud e o método dos diedros retos ou método de Angelier.

\subsubsection{1 - Método Arthaud}

ARTHAUD (1969) propôs a primeira técnica para a análise das estrias de atrito nas superficies de falhas. O método considera que a deformação leva a encurtamento segundo $Z$, estiramento segundo $X$ e encurtamento ou estiramentos menores segundo $Y$, com a massa rochosa aliviando as tensões através de deslocamentos de blocos (Figura 8). Se as falhas são formadas por um determinado evento, em um maciço anisotrópico, então esses deslocamentos não serão caóticos, mas guardarão uma coerência com a deformação global. Segundo ARTHAUD (1969), o plano do movimento de cada falha (plano M) expressa essa coerência. Esse plano é perpendicular a cada falha e ainda contém a estria (Figura 9).

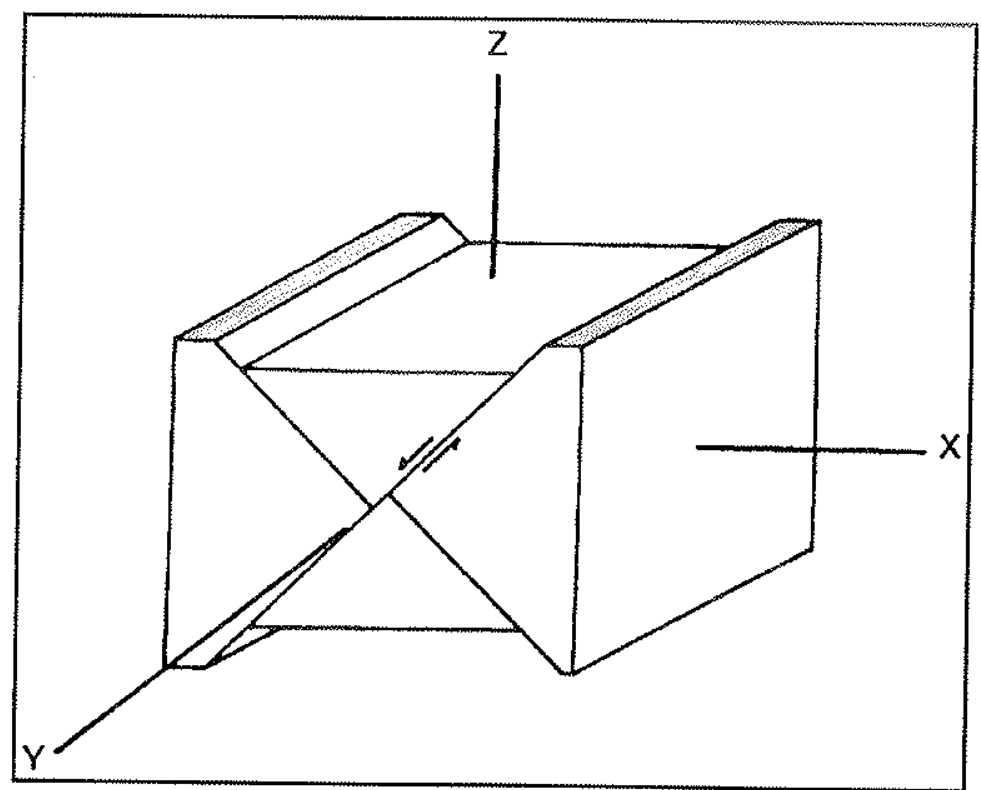

Figura 8 - Bloco diagrama mostrando um bloco falhado e a posição dos eixos $X, Y$ e $Z$, no conceito de Arthaud (1969). 


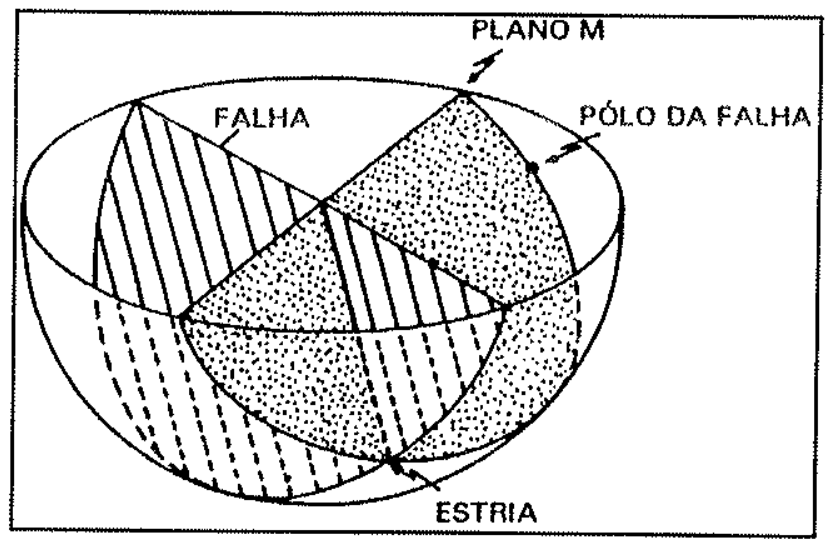

Figura 9 - Plano M, no conceito de Arthaud (1969).

Os estereogramas mostram os pólos dispersos segundo uma, duas ou três guirlandas que se entrecortam ortogonalmente, formando concentrações nas suas intersecções. Os planos formados representam os três planos de deformação e as intersecções os três eixos cinemáticos $X, Y$ e $Z$. O método de Arthaud é mais eficiente para deformação biaxial.

\subsubsection{2 - Método dos diedros retos ou Método de Angelier}

ANGELIER \& MECHLER (1977) descreveram o método gráfico conhecido como "Método dos Diedros", onde para cada falha admite-se dois planos ortogonais, o plano de falha (PF) e um plano auxiliar (PA), esse último ortogonal também às estrias (S) impressas no plano de falha. Assim é possivel delimitar quatro diedros retos, dois de compressão (C) e dois de extensão (E) (Figura 10).

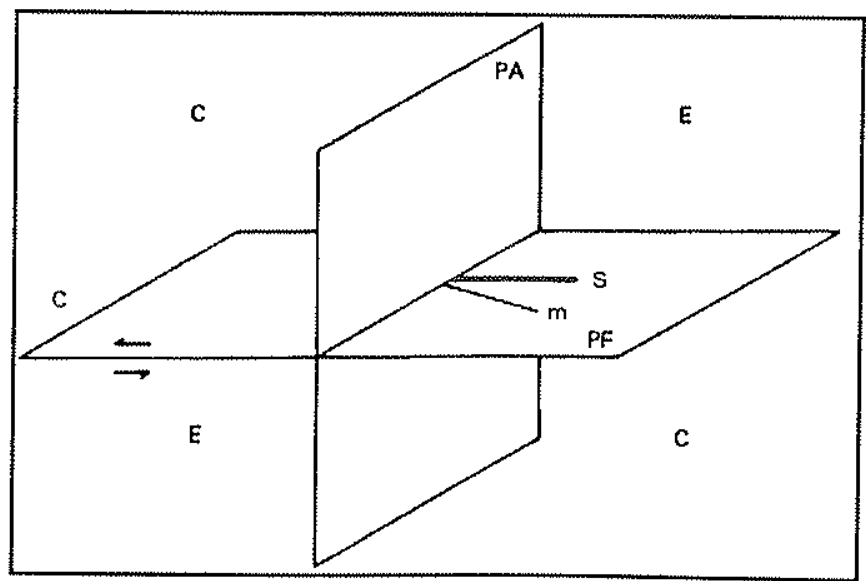

Figura 10 - Esquema dos diedros retos de compressão (C) e de extensão (E) numa região afetada pela falha PF. Notar que o PA é ortogonal às estrias (S) e não ao mergulho real da falha $(m)$. 
O método dos diedros retos considera que para cada falha de uma determinada familia de falhas, pode-se deduzir os quatro diedros que se sujeitaram, alternadamente a encurtamento e extensão. Estes diedros são definidos pelo plano de falha e por um plano que é perpendicular a ele e à estria. Pelo movimento relativo, pode-se inferir os diedros de encurtamento e estiramento. Em estereogramas, tais diedros expressam-se por quatro setores. Considerando numerosas falhas, muitos diedros de encurtamento ou de extensão apresentarão porções em comum, as quais definem os eixos $\sigma_{1}$ e $\sigma_{3}$, tanto mais precisamente quanto menores forem essas porções (Figura 11).

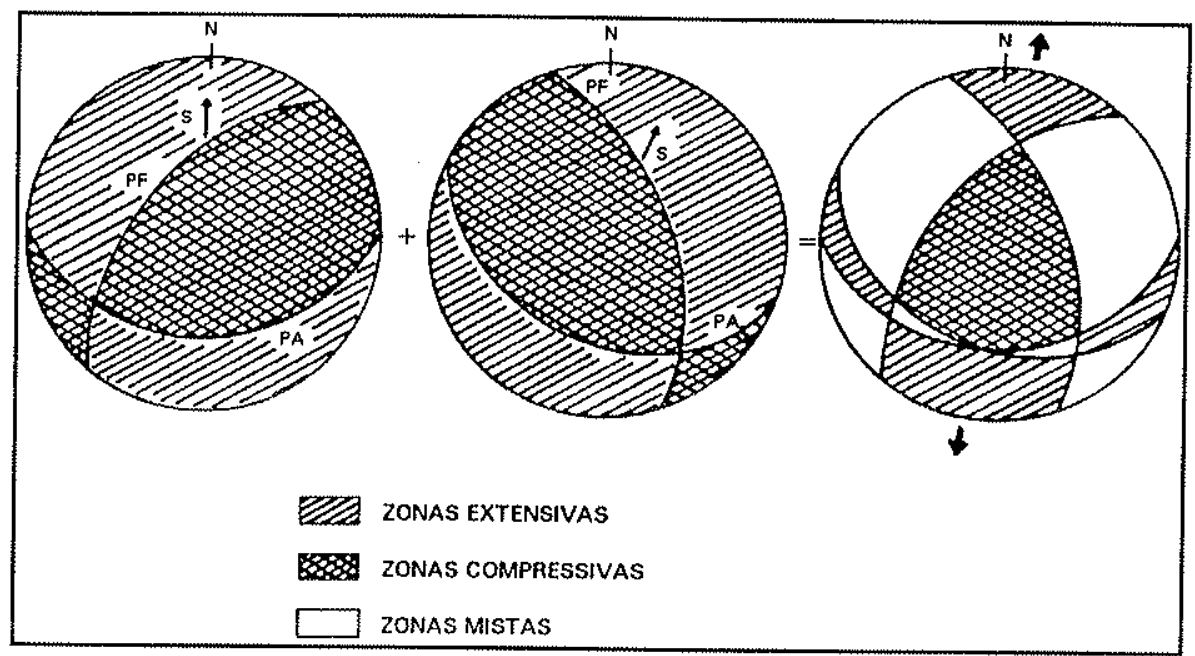

Figura 11 - Esquema do princípio elementar do método dos diedros retos mostrando um esquema em extensão. O somatório das duas primeiras figuras vai dar a última.

\subsection{2 - Aplicação em estudos de hidrogeologia}

Alguns exemplos de aplicação da análise cinemática das deformações de maciços rochosos em estudos hidrogeológicos são citados a seguir:

- análise estrutural na prospecção de fontes termais no Planalto de Poços de Caldas (ETCHEBEHERE et al,, 1992). Os lineamentos foram mapeados de fotografias aéreas 1:60.000, tendo sido produzidos mapas (a) de freqüência de lineamentos, (b) de densidade de lineamentos, (c) de intersecção de lineamentos e (d) de rosáceas de lineamento. A análise cinemática permitiu inferir que os eixos N330, vertical e N060, correspondem a $\sigma_{1}, \sigma_{2}$ e $\sigma_{3}$, ou seja, aos eixos principais de encurtamento, intermediário e elongação, respectivamente. Dessa forma as descontinuidades NNW seriam passiveis de maior abertura, e portanto capazes de condicionar a circulação hidráulica do maciço; 
- utilização do método de Arthaud para identificar os eixos do elipsóide de tensões numa seqüência de basaltos em estudos para a fundação da Barragem de Porto Primavera (Rio Paraná -SP) (MAGALHÃES et al., 1992);

- aplicação do método dos diedros retos para determinar os eixos de deformação/tensão do maciço, utilizando essas informações para orientar o projeto de drenagem de uma mina de carbonatito (Jacupiranga - SP) (HASUI \& MIOTO, 1992).

- aplicação da análise cinemática de fratura para a determinação dos esforços atuantes na região da borda da Bacia do Paraná e a sua correlação com a produção de poços profundos (FERNANDES, 1997).

Esses exemplos, embora não se relacionem especificamente à prospecção de água subterrânea, possuem em comum a pesquisa de um modelo de aqüifero (maciço) que representa a anisotropia hidrogeológica, mesmo que de forma qualitativa.

\section{4 - Hidrogeologia}

\subsection{1 - Importância e uso das águas subterrâneas}

Em muitos países, tais como Arábia Saudita, Austria, Alemanha, Bélgica, Dinamarca, Holanda, Itália, mais de $90 \%$ do abastecimento público é feito pelo manancial subterrâneo. Nos Estados Unidos nos últimos 25 anos, o consumo de água em geral, cresceu a uma taxa de $2 \%$ ao ano, enquanto o de água subterrânea atingiu praticamente $102 \%$. Estima-se que, atualmente entre 800 e $900 \mathrm{mil}$ poços são perfurados por ano nos Estados Unidos, sobretudo para produção e/ou monitoramento (REBOUÇAS, 1996).

As águas subterrâneas são utilizadas para irrigação de cerca de um terço do total da área irrigada do mundo. A China tem a maior área agrícola do mundo, 46 milhões de hectares, seguida da Índia, com 39 milhões, e dos Estados Unidos, com 20,5 milhões. Nos Estados Unidos o manancial subterrâneo irriga $45 \%$; na India $79,5 \%$ e na China mais de $50 \%$ (REBOUÇAS, 1996).

No continente latino-americano o uso deste recurso atende a mais de 140 milhões de pessoas. Pelo menos duas grandes conurbações no continente, Cidade do México e Grande Lima, são abastecidas em grandes proporções por águas subterrâneas. No caso da Cidade do México, um volume de $3.200 \mathrm{ML} /$ dia ( $94 \%$ do suprimento total em 1982) é originado pela captação dos 1.100 poços tubulares do Vale do México e 230 poços do Vale de Lerma. No caso da Grande Lima, as águas de uso doméstico e municipal têm origem em 320 poços 
tubulares, que produzem quantidades superiores a $650 \mathrm{ML} /$ dia. Em outras grandes cidades do continente, Buenos Aires (360 ML/dia) e Santiago do Chile (950 ML/dia), as águas subterrâneas suprem a maior parte do abastecimento público e privado (FOSTER et al., 1987).

Ademais, as águas subterrâneas têm uma função estratégica de grande alcance nas áreas metropolitanas em geral, a exemplo do que já se pratica em algumas cidades do Primeiro Mundo, tais como Paris, Londres, Nova lorque, Los Angeles, Barcelona, Madri. Nestes casos, as águas subterrâneas são conservadas e até recebem recarga artificial, para serem acionadas em momentos de crise climática ou de acidente ambiental ou terrorista que venha afetar o manancial superficial (REBOUÇAS, 1994).

O relativo baixo custo e, na maioria dos casos, a excelente qualidade natural das águas subterrâneas têm sido suficientes para justificar sua exploração como fonte de água potável, mesmo em muitas regiões de clima tropical úmido. No Brasil, estima-se a existência de 200.000 poços tubulares ativos (além de milhões de poços rasos escavados), que fornecem água para diversos fins, sobretudo o abastecimento urbano, permitindo suprir as necessidades de mais da metade da população (REBOUÇAS \& MENEZES, 1988). Em praticamente todas as áreas metropolitanas do país, os poços vêm se constituindo em fonte complementar importante de abastecimento, face aos problemas de falta de água do sistema público e como forma de redução de custos.

No Estado de São Paulo, estima-se que 60,5\% dos núcleos urbanos são servidos exclusivamente $(45,4 \%)$ ou parcialmente $(15,1 \%)$ por fontes subterrâneas (IG, 1997). Na Grande São Paulo estima-se em 7.000 o número de poços em operação, abastecendo hotéis, hospitais, condomínios residenciais e indústrias. A população equivalente abastecida é estimada em 5 milhões (REBOUÇAS, 1994).

\subsection{2 - Hidrogeologia de aqüiferos fraturados}

\subsubsection{1 - Generalidades}

A hidrogeologia dos aqüiferos fraturados tem a sua principal aplicação no domínio das rochas ígneas e metamórficas, genericamente designado como cristalino. Neste dominio, podem ser distinguidos dois aqüiferos de comportamento bastante distintos (COSTA \& SILVA, 1997): o aqüifero poroso ou intersticial e o aqüíferö de rocha sã fraturada. 
O primeiro mais superficial é formado por capeamentos procedentes de uma sedimentação de material estranho à rocha subjacente ou encoberta (cobertura alóctone) como os depósitos de aluviões e coluviões, bem como por materiais procedentes de processos de intemperismo da própria rocha subjacente (cobertura autóctone).

O segundo, mais profundo, se constitui da zona fraturada de rocha sã. Nesse domínio a matriz do maciço rochoso é caracterizada pela inexistência ou presença muito reduzida de espaços intergranulares na rocha. Nesse meio, a água encontra-se em espaços representados por fissuras ou fraturas, juntas ou ainda em falhas e, em casos particulares, em vesículas, aberturas de dissolução, zonas de decomposição, dentre outros.

Segundo UNESCO (1984), esses aqüiferos não estão isolados, apresentando certo grau de comunicação entre eles, sendo que o aqüifero poroso exerce papel importante na recarga do aqüifero de rocha sã fraturada. Tal idéia é corroborada por BERTACHINI (1987), CAVALCANTE (1990) e MENEGASSE (1991).

O aqüífero de rocha sã fraturada, devido às suas descontinuidades, precária homogeneidade e forte anisotropia, não apresenta parâmetros hidrodinâmicos constantes (COSTA \& SILVA, 1997). No aqüífero poroso ou intersticial, a porosidade é responsável pelo coeficiente de armazenamento enquanto a condutividade hidráulica corresponde diretamente à transmissividade para uma determinada espessura do aqüífero. A vazão especifica guarda também uma certa relação com o rebaixamento do poço. Em contrapartida, no aqüifero de rocha sã fraturada, a porosidade é meramente função das fissuras, não se distribuindo homogeneamente em todo o aqüífero, mas variando muito de um ponto a outro. Assim, em determinada zona do maciço, onde não ocorre nenhuma fratura, a porosidade equivalente é praticamente nula, podendo ser relativamente elevada numa outra zona, onde haja uma concentração de fraturas.

Igualmente, a condutividade hidráulica dependerá fundamentalmente do fraturamento, não havendo nenhum sentido de se falar em transmissividade do aqüifero, uma vez que, se ao longo da fratura existe uma determinada condutividade hidráulica, não se pode extrapolar esse valor para uma determinada espessura do aqüifero, onde predominam zonas não fraturadas, onde a intercomunicação das fraturas se faz incipientemente ou mesmo deixa de existir. Os valores de condutividade hidráulica encontrados em ensaios de laboratório, citados por COSTA \& SILVA (1997), acusam resultados muito baixos para as rochas do cristalino em geral, na faixa de $10^{-10}$ a $10^{-12} \mathrm{~m} / \mathrm{s}$.

Segundo UNESCO (1984), os poços que exploram essencialmente o aqüifero poroso nas regiões de clima úmido do Brasil apresentam valores de vazão entre 0,5 e $15 \mathrm{~m}^{3} / \mathrm{h}$ e de 
capacidade específica entre 0,2 e $4 \mathrm{~m}^{3} / \mathrm{h} / \mathrm{m}$. Na área de Atibaia, CAVALCANTE (1990) obteve, através de testes de vazão em 3 poços cacimba, que exploram somente o aqüifero poroso (espessura máxima de $59 \mathrm{~m}$ ), capacidade específica média de $0,225 \mathrm{~m}^{3} / \mathrm{h} / \mathrm{m}$. Os valores de condutividade hidráulica nestes aqüíferos é de $10^{-7}$ a $10^{-6} \mathrm{~m} / \mathrm{s}$ (REBOUÇAS \& CAVALCANTE, 1987).

\subsubsection{2 - Fatores que atuam na capacidade de armazenamento de água}

Os fatores que atuam no mecanismo de infiltração, percolação e armazenamento da água em rochas fraturadas e, conseqüentemente, na capacidade do aqüifero fraturado podem ser divididos em dois grupos (COSTA \& SILVA, 1997): endógenos e exógenos.

O primeiro grupo corresponde aos agentes que atuam no interior do globo, representado principalmente pela própria crosta, tais como: estruturas apresentadas pelas rochas em função dos esforços atuantes, constituição mineralógica das rochas (paragêneses magmáticas, sedimentares ou metamórficas) e pela presença de soluções mineralizantes hidrotermais.

O segundo grupo diz respeito aos agentes atuantes na superficie externa do globo terrestre, tais como o clima da região, relevo, hidrografia, vegetação, infiltração de soluções e intemperismo.

\subsubsection{1 - Fatores endógenos}

\section{Litologia}

A importância da litologia reside no fato dela exercer influência tanto nos padrões de fraturamento como nas caracteristicas do manto de intemperismo (FERNANDES, 1997). Em relação aos padrões de fraturamento, a granulação da rocha exerce influência no sentido de que quanto maiores e mais desenvolvidos os cristais (como em pegmatitos) mais quebradiça é a rocha, enquanto nas rochas de granulação fina (microgranito, por exemplo) a resistência ao fraturamento é maior. Considerando estes aspectos, COSTA \& SILVA (1997) propuseram a seguinte relação de potencialidade (condições de armazenamento em suas fraturas) das rochas, em ordem decrescente:

- pegmatitos; 
- gnaisses, migmatitos (epibolíticos), quartzitos e cataclasitos;

- micaxistos e calcário cristalino (mármores);

- granitos, dioritos, sienitos, gabros, migmatitos homogêneos;

- ardósias, filitos, sericita-xistos.

Uma outra situação litológica favorável é a do contato entre duas unidades litológicas distintas, tais como entre um granito e um gnaisse, ou entre um migmatito e um micaxisto (COSTA \& SILVA, 1997). Além disso, o contato de pequenos corpos intrusivos com grandes diferenças texturais e/ou mineralógicas com relação às encaixantes pode apresentar uma major permeabilidade, devido ao fraturamento gerado por mecanismos de intrusão (FERNANDES, 1997).

Quanto ao manto de intemperismo, o tipo de rocha exerce influência na sua permeabilidade. Segundo UNESCO (1984) algumas rochas, tais como dioritos, gabros e diabásios desenvolvem manto de intemperismo bastante impermeável, enquanto que o derivado de quartzitos, gnaisses quartzosos e metarenitos apresentam maior permeabilidade.

\section{Estruturas geológicas}

As estruturas geológicas constituem o fator mais importante no problema de potencialidade da água subterrânea em rochas fraturadas. As principais estruturas rúpteis favoráveis à infiltração e acumulação de água são: as falhas ou paráclases, fraturas ou diáclases, juntas de origens diversas e planos de xistosidade e de clivagem (COSTA \& SILVA, 1997).

Segundo estes autores, dentre as falhas ou paráclases, a mais favorável é a normal ou falha de gravidade, pois, sendo originada por esforços tracionais, tende a, na maioria dos casos, propiciar descontinuidades com maiores aberturas. As falhas provenientes de esforços compressivos (falhas inversas e transcorrentes) acarretam planos muito fechados, sobretudo as transcorrentes que são associadas a processos de milonitização e cataclase dos minerais.

Em diaclasamento, destacam-se os seguintes tipos de fraturas: 
- fratura transversal (tipo ac de Sander) de esforço tracional (Figura 12), que em geral possui maior abertura;

- fratura paralela ao eixo da dobra (tipo bc de Sander), também decorrente de esforço tracional, na parte externa da dobra (Figura 13);

- fratura longitudinal por alívio de pressão (também correspondendo ao tipo bc de Sander) e decorrente ainda de esforço tracional, quando dos movimentos epirogenéticos positivos (Figura 14);

- juntas de descompressão ("sheet joints") que se devem a processos exógenos, de alívio de pressão pela erosão superficial, acarretando assim esforços tracionais (Figura 15).

Quanto às rupturas por cisalhamento, que tanto podem acarretar falhas do tipo transcorrente, como simples fraturas longitudinais ou angulares (tipo hko ou hol de Sander) são sempre desfavoráveis para a locação de poços, pois as suas aberturas são muito reduzidas, chegando mesmo a serem "reseladas", nos casos de milonitização.

Dentre as juntas de origem diversas, além das de descompressão ("sheet joints"), podem ainda ser mencionadas as juntas de resfriamento, originadas na consolidação de rochas vulcânicas de grã fina como os basaltos. Essas juntas são em geral quase "soldadas", desempenhando um reduzido papel como conduto e armazenamento da água.

Os planos de descontinuidade originais das rochas metamórficas, como a xistosidade dos micaxistos ou a clivagem das ardósias também desempenham uma certa importância, principalmente quando associados às estruturas naturais, aumentando-thes a intercomunicação e, conseqüentemente, a permeabilidade do maciço rochoso. A percolação de água ao longo desses planos de descontinuidade original faz-se muito lentamente, muitas vezes por forças capilares, mas desempenham importante papel nos processos de decomposição química, sendo muito comum encontrar-se as superfícies desses planos completamente oxidadas.

A associação do diaclasamento com o dobramento e com as descontinuidades desempenha importante papel na indicação para a locação de poços. Assim, as estruturas dobradas decorrentes de esforços compressivos de elevada intensidade, acarretando mergulhos dos flancos das dobras, com ângulos superiores a $60^{\circ}$ são em geral desfavoráveis, pois em tais situações as rochas adquirem maior plasticidade e menor 


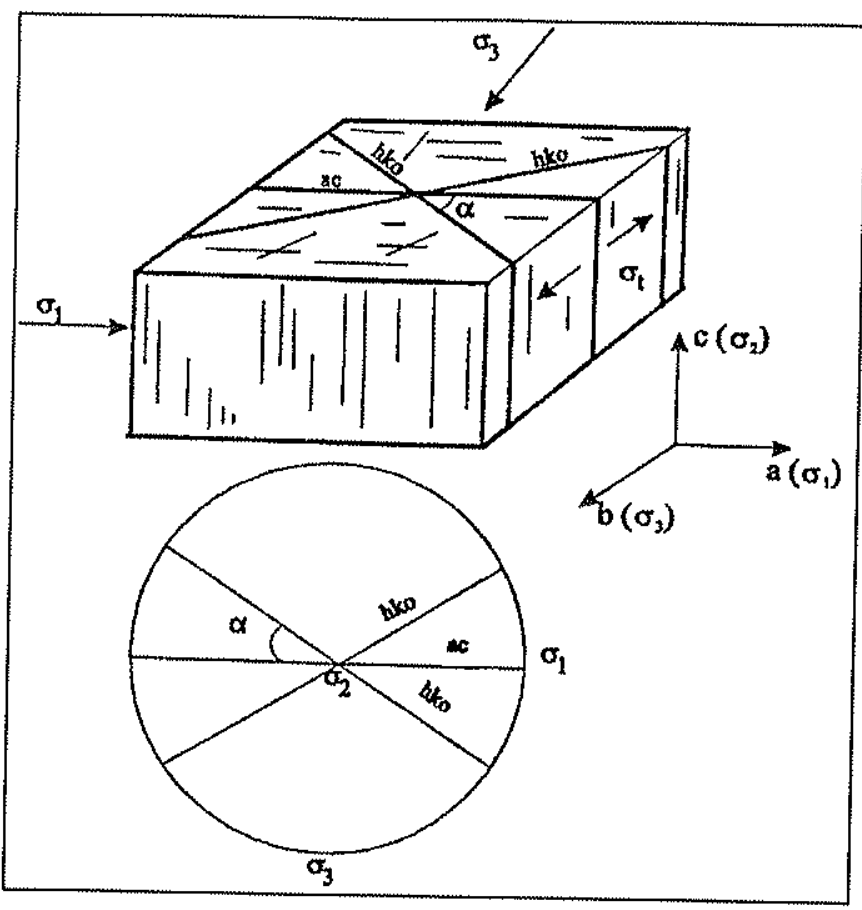

Figura 12 - Quando o estado de tensões atuante corresponde ao representado pelos eixos $a, b, c$, podem se desenvolver fraturas de cisalhamento (hk0 de Sander) ou de tração (ac) (COSTA \& SILVA, 1997).

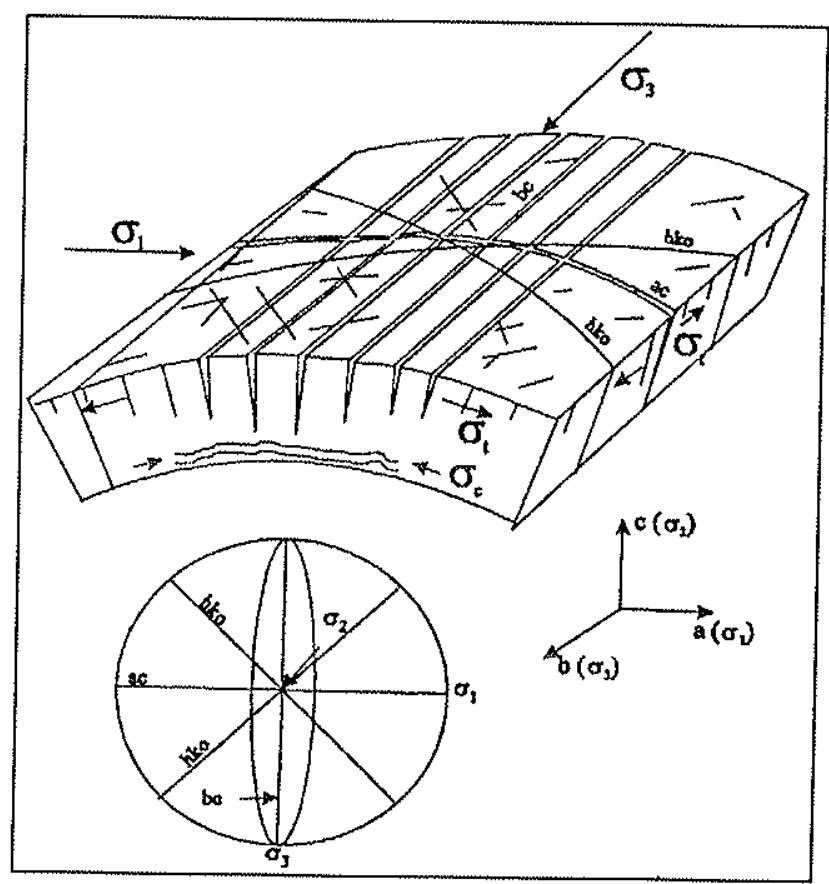

Figura 13 - Fraturamento em dobras de grande raio de curvatura. A fratura mais central coincide com o plano axial e contém a crista da dobra (fratura bc de Sander). As demais desse tipo (paralelas a $\underline{\text { bc) }}$ ) apresentam ligeiro mergulho para o centro da dobra (COSTA \& SILVA, 1997). 


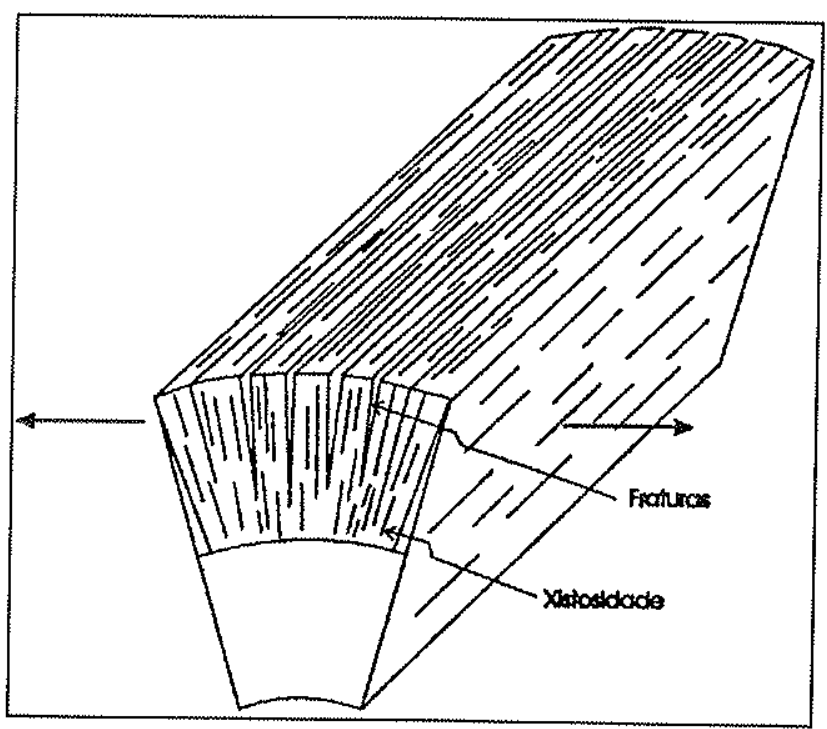

Figura 14 - Fraturas longitudinais desenvolvidas ao longo dos planos de xistosidade, por alívio de pressão (COSTA \& SILVA, 1997).

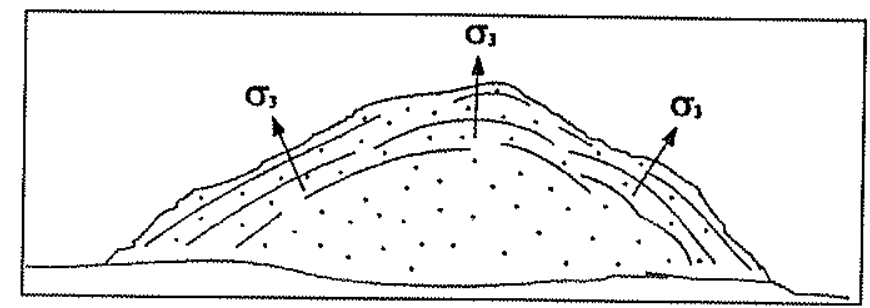

Figura 15 - Esquema da formação das juntas de descompressão ou "sheet joints". Por erosão, a tensão $\sigma_{3}$ passa de compressiva para tracional, acarretando o fendilhamento paralelo à superfície topográfica (COSTA \& SILVA, 1997).

desenvolvimento, além de possuir planos mais fechados de descontinuidades originais. Ao contrário, os dobramentos cujos flancos apresentem ângulos de mergulho inferiores a $30^{\circ}$, propiciam maiores aberturas em fraturas longitudinais (tipo bc de Sander) e maiores possibilidades de armazenamento de água ao longo dos planos de descontinuidade originais.

\subsubsection{2 - Fatores exógenos}

\section{Clima}

O clima é um fator controlador indireto na capacidade de armazenamento de água, pois sua influência está relacionada aos processos de intemperismo da rocha e 
conseqüente formação de um manto de intemperismo ou regolito. O intemperismo químico é dominante em clima tropical úmido, podendo alcançar profundidades de dezenas de metros, enquanto o intemperismo físico predomina em climas áridos ou semi-áridos, produzindo em conseqüência, solos muito delgados, de apenas alguns centímetros, eventualmente chegando a um ou dois metros.

\section{Relevo}

A configuração do relevo é de grande importância para a capacidade ou volume de água produzido no cristalino. (COSTA \& SILVA, 1997).

Estudos realizados nos Estados Unidos e Canadá por LEGRAND (1959 apud COSTA \& SILVA, 1997), revelaram que independentemente do tipo de rocha, a pior situação morfológica para a locação de um poço é no topo de uma elevação (colina, monte, etc) e secundariamente, nos flancos ou vertentes da elevação, ao contrário, a melhor situação morfológica, situa-se nas depressões, secundadas por áreas de planície.

Num outro estudo, PARIZEK \& SIDDIQUI (1969 apud FERNANDES, 1997) verificaram que poços perfurados na base de vales chegam a ser oito vezes mais produtivos do que nos terrenos de topo, e que aqueles perfurados nas encostas também tendem a ser mais produtivos, quando comparados aos de topo.

Por outro lado, HENRIKSEN (1995) acredita que áreas planas, inclusive topograficamente elevadas, também podem ser significativamente produtivas, devido ao fato de que os vales e as áreas planas (mesmo elevadas) apresentam coberturas superficiais mais espessas e recarga adicional de corpos de água superficial.

\section{Hidrografia}

A hidrografia exerce influência no armazenamento de água em sub-superfície quando ocorre a coincidência da drenagem superficial com zonas fraturadas do embasamento rochoso, caracterizando a feição conhecida como riacho-fenda. Nessa situação existe a condição de infiltração de água nas aberturas de rocha proporcionadas pelos fraturamentos, com possibilidades favoráveis de armazenamento no subsolo. 


\section{Vegetação}

A vegetação, assim como o clima, atua de maneira indireta no armazenamento de água no subsolo, pois à medida que dificulta o escoamento superficial, propicia condições de maior infiltração. Além disso, quanto maior é a cobertura vegetal, mais elevada é a evapotranspiração e, conseqüentemente, maiores serão as precipitações que irão proporcionar melhores condições de recarga aos aqüiferos. Ao contrário, em regiões de vegetação escassa (mesmo nas regiões de mata chuvosa e do sertão semi-árido), as precipitações também o serão, diminuindo a taxa de recarga dos aqüiferos.

Há de se ressaltar também, que mudanças do regime de escoamento superficial e subterrâneo (conseqüência do desmatamento e das diversas formas de uso do solo), são apontadas como principal causa dos processos erosivos.

\section{Infiltração de soluções e detritos}

As soluções com elevada concentração de sílica, associada ou não ao ferro, podem produzir a cimentação total ou parcial das fraturas. Nesses casos, os reservatórios hidricos ficam definitivamente comprometidos, diminuindo ou até mesmo impermeabilizando totalmente o meio fraturado, que se transforma num aqüifugo .

Se ao invés de substâncias dissolvidas, a água infiltrada carrear material detrítico, o efeito resultante poderá ser uma obstrução apenas parcial do meio fraturado, quando esses detritos são grosseiros (fração areia) ou uma impermeabilização quase total se o detrito for fino (fração argila).

Segundo COSTA \& SILVA (1997) a origem do material pode estar ligada a:

- fragmentos da própria rocha fraturada (material autóctone), em geral nas fraturas de cisalhamento ou zonas de falha provocada por compressão (Figura 16-a);

- detritos de origem superficial, que penetraram em meio aquoso, de elevada turbidez, decantando no interior das fraturas (Figura 16-b);

- recristalização de sais que se precipitam através de soluções saturadas, em função da evaporação do meio líquido que os transportou. Esse processo pode produzir uma cimentação da fratura ou mesmo uma eflorescência (Figura 16-c); 
- ascensão de soluções hidrotermais mineralizantes, solidificando-se em forma cristalina ou amorfa, em função do resfriamento (Figura 16-d).

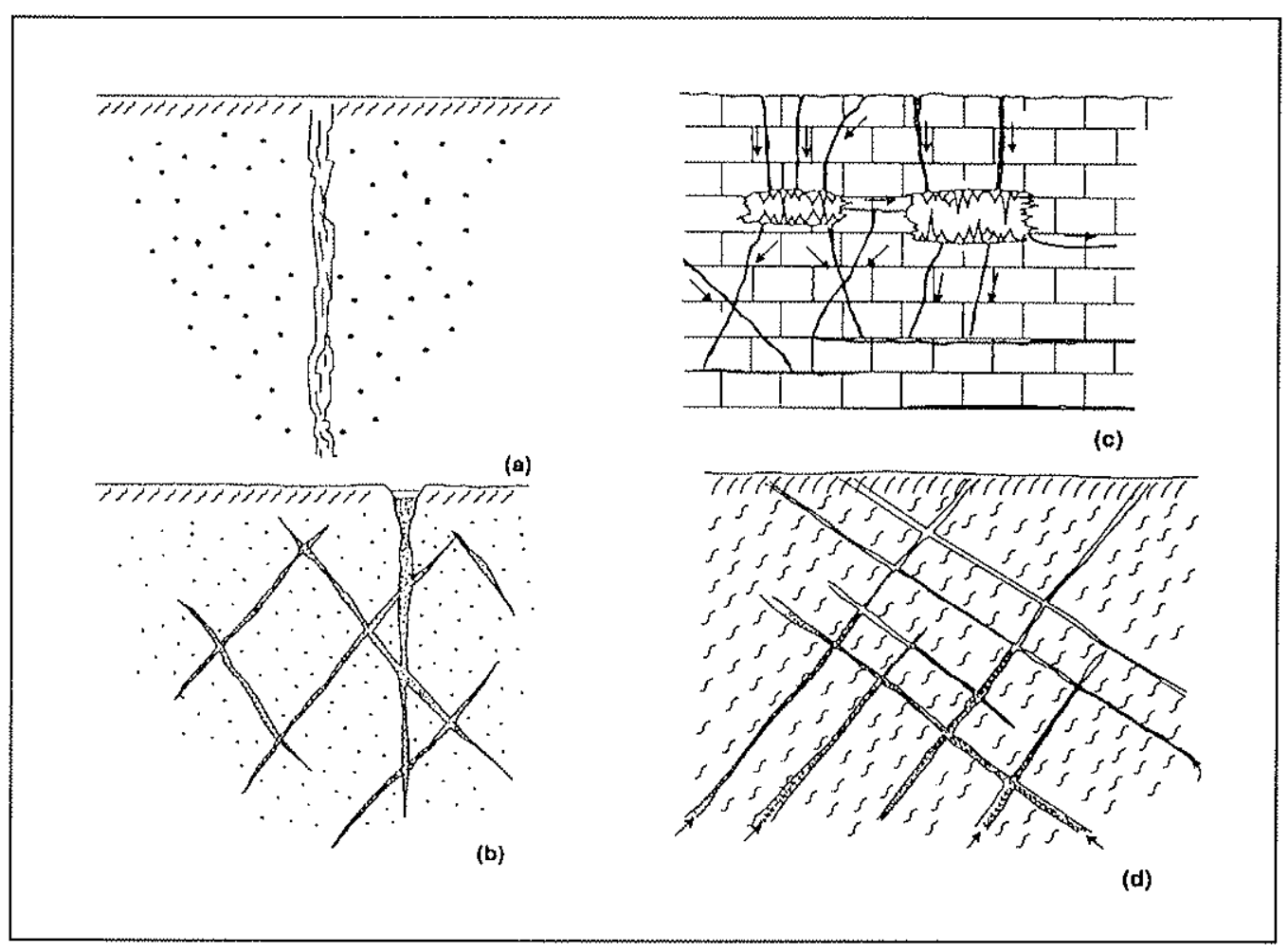

Figura 16 - Tipos de infiltração e preenchimento de fraturas: (a) o material de preenchimento provém da própria rocha; (b) o material infiltrou-se em meio aquoso superficial decantando dentro da fratura; (c) o material entrou em solução a partir da superfície; (d) percolação por solução hidrotermal (COSTA \& SILVA, 1997).

\subsubsection{3 - Fluxo em meios fraturados}

\subsubsection{1 - Generalidades}

Nos meios fraturados, com porosidade essencialmente de fraturas, o escoamento é determinado pela permeabilidade da matriz rochosa e pela condutividade hidráulica das descontinuidades.

Em rochas cristalinas, com baixo grau de porosidade, o escoamento pela matriz é praticamente nulo e as descontinuidades desempenham papel fundamental no escoamento. A comparação de medidas de permeabilidade efetuadas em matrizes rochosas indicam que esta é desprezivel, em relação ao valor da condutividade hidráulica das descontinuidades.

Sendo a permeabilidade matricial geralmente inferior a $10^{-8} \mathrm{~cm} / \mathrm{s}$, a matriz pode ser considerada como impermeável, em comparação com as descontinuidades que, mesmo 
com aberturas muito pequenas, apresentam valores de condutividade hidráulica significativamente maiores (Tabela 1), sendo estas que efetivamente controlam o fluxo nos maciços rochosos fraturados.

Tabela 1 - Comparação entre os coeficientes de permeabilidade de algumas rochas e de um maciço rochoso fraturado (QUADROS, 1982).

\begin{tabular}{|c|c|c|c|}
\hline \multicolumn{2}{|c|}{ Rocha } & \multicolumn{2}{|c|}{$\begin{array}{l}\text { Maciço rochoso com uma fratura por } \\
\text { metro }\end{array}$} \\
\hline Natureza & $\begin{array}{l}\text { Permeabilidade } \\
\text { matricial }(\mathrm{cm} / \mathrm{s})\end{array}$ & $\begin{array}{l}\text { Abertura das } \\
\text { fraturas }(\mathrm{mm})\end{array}$ & $\begin{array}{c}\text { Permeabilidade na } \\
\text { direção das fraturas } \\
(\mathrm{cm} / \mathrm{s})\end{array}$ \\
\hline 1-Calcário Sedimentar & 0,36 a $23 \times 10^{-13}$ & 0,1 & $0,7 \times 10^{-4}$ \\
\hline 3 - Arenito Carbonífero & 0,29 a $6 \times 10^{-11}$ & 0,4 & $0,5 \times 10^{-2}$ \\
\hline 4 - Arenito Devoniano & 0,21 a $2 \times 10^{-11}$ & 0,7 & $2,5 \times 10^{-2}$ \\
\hline 5 - Granito & 0,5 a $2 \times 10^{-10}$ & 1,0 & $0,7 \times 10^{-1}$ \\
\hline 6 - Xisto & 0,7 a $1,6 \times 10^{-10}$ & 2,0 & 0,6 \\
\hline 7 - Calcário & 0,7 a $120 \times 10^{-9}$ & 4,0 & $0,5 \times 10$ \\
\hline 8 - Dolomita & 0,5 a $1,2 \times 10^{-8}$ & 6,0 & $1,6 \times 10$ \\
\hline
\end{tabular}

Portanto, interessam ao fluxo todas as descontinuidades presentes nas rochas, descontinuidades aqui entendidas como toda e qualquer estrutura que corta o maciço, englobando as diáclases, juntas, fraturas e falhas, tornando-o essencialmente descontínuo, heterogêneo e anisotrópico. Acamamentos, xistosidades, estratificações, etc., embora sejam estruturas do maciço, podem não se constituir em descontinuidades em relação ao fluxo d’água, uma vez que são feições intrínsecas à matriz rochosa.

Assim, é de importância considerar os diferentes tipos litológicos, pois as descontinuidades presentes estão intimamente ligadas à sua gênese e aos esforços a que estes estiveram submetidos durante a sua evolução.

Genericamente, pode-se dizer que os maciços sedimentares, quando não deformados, possuem descontinuidades essencialmente plano-horizontais, associadas aos planos de acamamento/estratificação, - enquanto que nos maciços metamórficos, os planos de fraturamento e de xistosidade/gnaissificação são resultantes do tipo e da direção dos esforços que originaram as deformações. Por sua vez, os maciços magmáticos, conforme a 
(intrusivos ou extrusivos, ácidos ou básicos, etc.), possuem padrões de descontinuidades totalmente diversos dos anteriores. Somem-se a estes, os fatores decorrentes do clima e relevo que condicionam a alteração superficial e o desenvolvimento de mantos de alteração, bem como a penetração ou não desta alteração ao longo das descontinuidades. Além disso,fatores da dinâmica interna e externa podem determinar condições de contorno, ou condições limites, criando ou destruindo fronteiras permeáveis ou impermeáveis no interior dos maciços.

A Figura 17 apresenta, de forma esquemática, modelos teóricos da distribuição da permeabilidade em diferentes tipos de maciços, em função da profundidade.

De modo geral, nos granitos e nas rochas de alto grau de metamorfismo, como gnaisses, migmatitos, granulitos, etc., a permeabilidade tende a zero em profundidade, devido ao confinamento. Em superficie, por alivio de tensões, as fraturas se encontram mais abertas, resultando não só em um aumento da permeabilidade do maciço, como também no desenvolvimento de juntas de tração. Estas são descontinuidades de andamento subparalelos à topografia e que mostram condutividades hidráulicas elevadíssimas (Figura 17-a).

Por outro lado, em vulcânicas extrusivas, como os basaltos, geradas por emissões sucessivas de lavas, a qualquer profundidade são esperadas descontinuidades subhorizontais de alta condutividade hidráulica (contato entre diferentes derrames), separadas por corpos tabulares praticamente estanques. Estes corpos tabulares podem apresentar no seu interior descontinuidades também subhorizontais, subparalelas aos contatos, também de elevada condutividade hidráulica (Figura 17-b).

Este comportamento é análogo àquele dos maciços de rochas sedimentares, ressalvado que as descontinuidades podem não ser tão expressivas e as condutividades hidráulicas tão elevadas. Em cada estrato, a permeabilidade é função da granulometria, imbricamento, tipo e quantidade de matriz e de cimento, etc. (Figura 17-c).

Nas rochas de médio a baixo grau metamórfico (xistos, filitos, etc.) verifica-se, em geral, um horizonte de rocha alterada bem desenvolvido e, embora a permeabilidade diminua com a profundidade, esta diminuição não é tão pronunciada quanto aquela verificada nas rochas magmáticas intrusivas ou de alto grau metamórfico. Normalmente, a passagem da zona de rocha alterada para a rocha sã é relativamente brusca, havendo, concomitantemente, uma diminuição significativa na permeabilidade do maciço. 


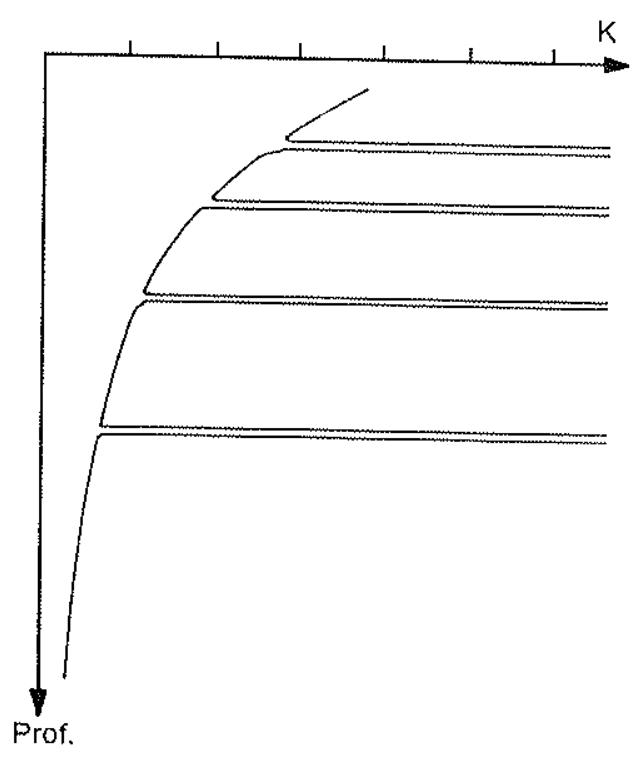

a GRANITOS E ROCHAS METAMÓRFICAS DE ALTO GRAU (GNAISSES, MIGMATITOS, GRANULITOS)

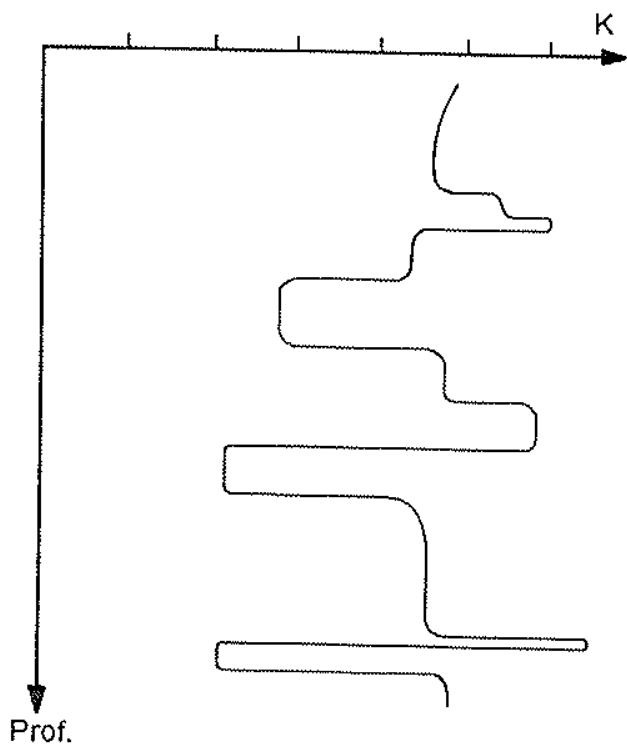

C ROCHAS SEDIMENTARES

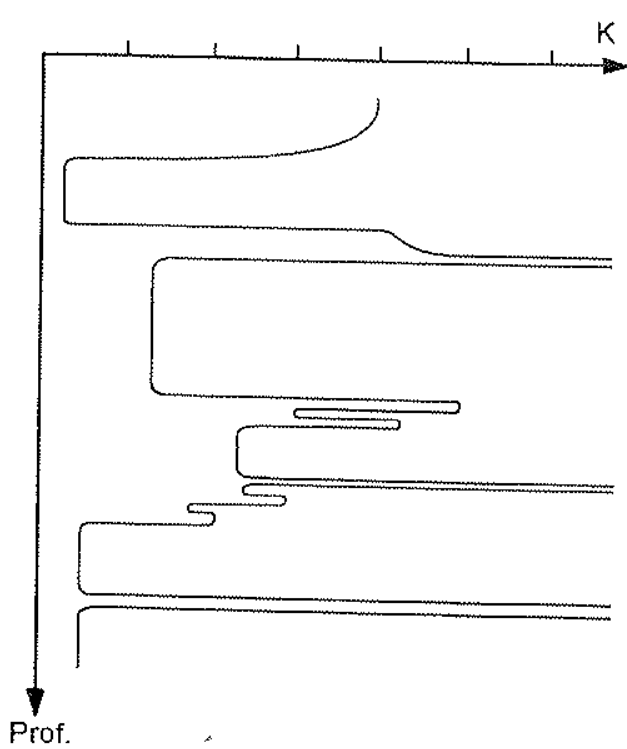

b ROCHAS EFUSIVAS BÁSICAS (BASALTOS)

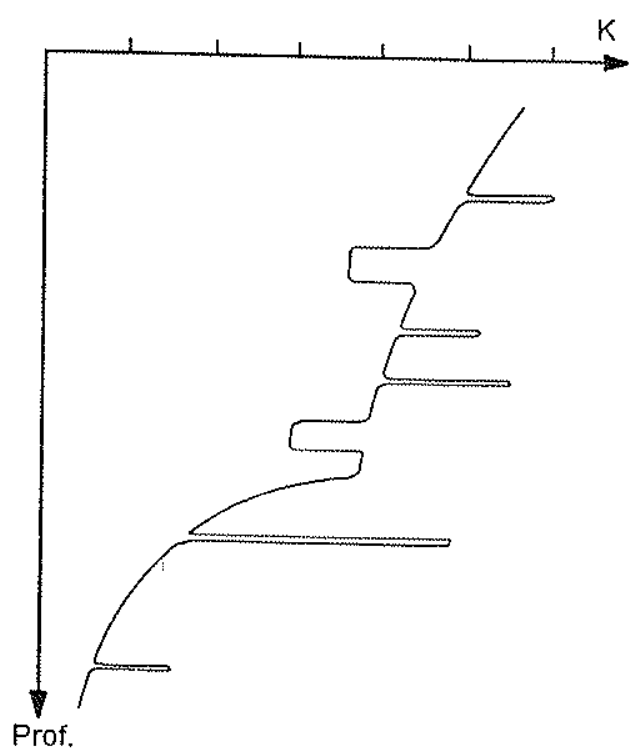

d ROCHAS METAMÓRFICAS DE MÉDIO E BAIXO GRAU (XISTOS, ARDÓSIAS, FILITOS)

Figura 17 - Comportamento esperado da permeabilidade em diferentes litologias em função da profundidade (AZEVEDO \& ALBUQUERQUE, 1998).

Freqüentemente, estes maciços são entrecortados por veios de quartzo ou de outros materiais, remobilizados ou não, que conferem, localmente, permeabilidades elevadas ao maciço, favorecendo a ocorrência de alteração e elevadas permeabilidades, mesmo a niveis profundos. Horizontes mais argilosos podem resultar em trechos menos permeáveis na zona alterada (Figura 17-d). 
Depreende-se que conhecer as características dos maciços, e particularmente das descontinuidades, é de extrema importância para o estudo da permeabilidade em meios fraturados. Nestes, os principais parâmetros que influenciam o escoamento são :

- orientação espacial das familias de descontinuidades (atitude);

- abertura das descontinuidades (e);

- espaçamento entre as descontinuidades (I);

- rugosidade absoluta das paredes $\left(R_{a}\right)$.

Dentre todos estes parâmetros, abertura e rugosidade (Figura 18) constituem os mais importantes para o estudo do escoamento em meios fraturados e a sua determinação pode ser efetuada mediante as leis que governam o fluxo d água nas fraturas.

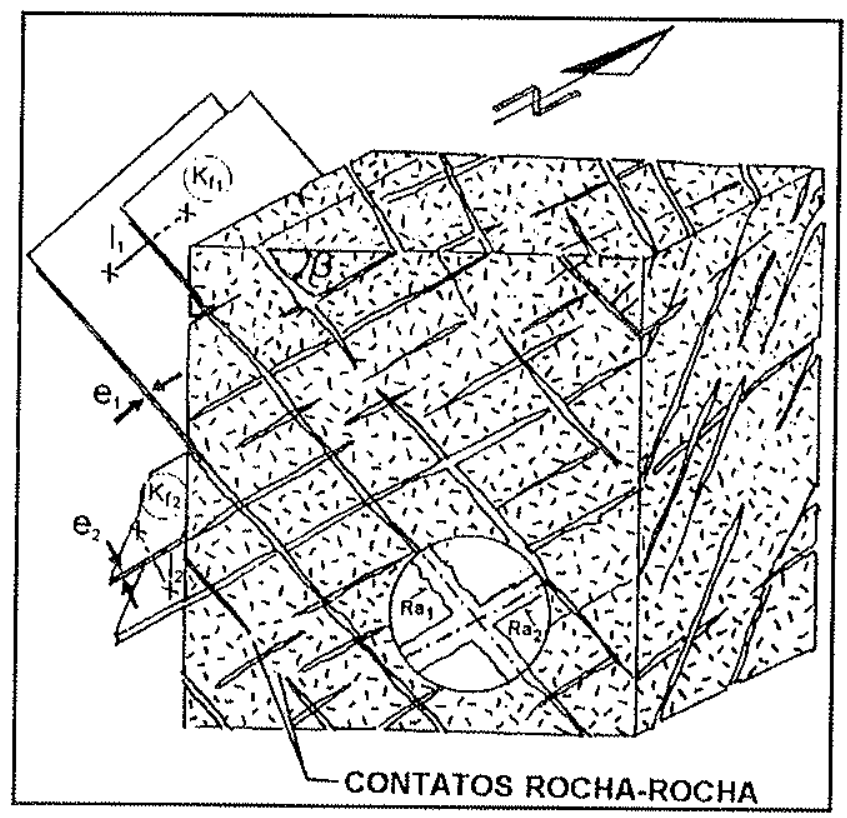

Figura 18 - Maciço rochoso fraturado, evidenciando os parâmetros de interesse ao fluxo (RISSLER, 1978 apud QUADROS, 1982).

\subsubsection{2 - Fluxo em maciços rochosos}

Os maciços rochosos são entrecortados por diversas famílias de descontinuidades, cada qual com sua atitude e uma distribuição do espaçamento e abertura de fraturas que Thes são particulares. Em geral, as fraturas nos maciços são de dimensões finitas quando comparadas à escala do problema, porém o fluxo em uma fratura não é independente das demais, ou seja, para percolar através das fraturas em uma certa direção, o fluido terá que 
percolar através de fraturas em outras direções que se interconectam às primeiras (CELESTINO, 1986). Portanto, não é possivel tratar de forma individual cada uma das fraturas presentes no maciço.

Para a determinação dos parâmetros hidráulicos de maciços rochosos são utilizados basicamente dois métodos: amostragem de fraturas e ensaios hidráulicos de campo.

O primeiro método baseia-se na obtenção de informações acerca do sistema de fraturas do maciço (número de famílias, orientação, abertura, espaçamento, preenchimento, etc.), a partir do qual é obtido, por determinação analitica, um tensor de permeabilidade (Figura 19), ou seja, a determinação no espaço, dos módulos e das direções principais (triortogonais) de permeabilidade (ex. SNOW, 1966; LOUIS, 1974; ROCHA \& FRANCISS, 1977).

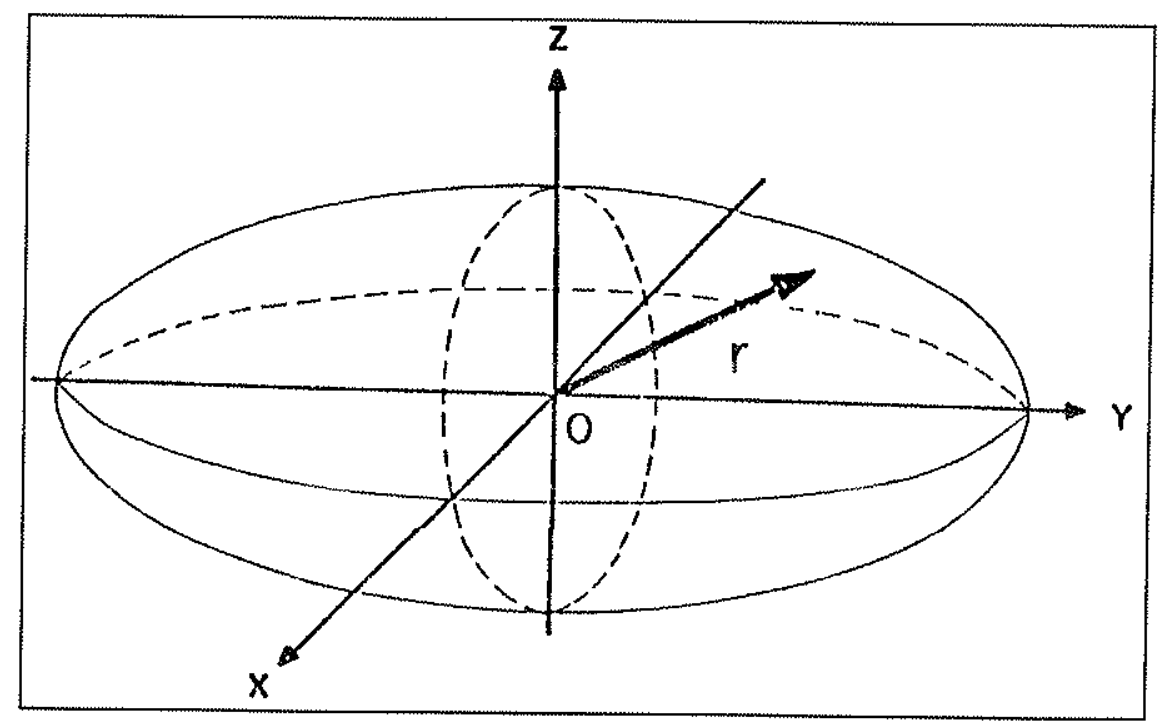

Figura 19 - Elipsóide de condutividade hidráulica num sistema de referência $X, Y, Z$ (QUADROS, 1992).

O método de amostragem de fratura é feito preferencialmente dentro de furos de sondagem e pode empregar diferentes técnicas como: obturador de impressão, videoscopia e Teste de Registro Hidráulico (TRH), conforme explicados por SOUZA et al., (1998) em seguida. O obturador de impressão é um equipamento que permite registrar todos os sinais físicos do maciço, exibidos nas paredes dos furos de sondagem. O obturador consiste numa mangueira fina, de borracha mole, muito plástica que, quando pressionada contra a parede do furo, por um obturador inflável, fica permanentemente marcada com as suas irregularidades. Este equipamento pode ser orientado em relação às coordenadas geográficas, desde a superfície do terreno, com um hästeamento rígido dotado de uma bússola. Na videoscopia, câmaras de vídeo miniaturizadas e com fonte de luz permitem a 
obtenção de imagens das paredes dos furos, cujas distorções são corrigidas por meio de processamentos em computador, permitindo a obtenção de vistas planas. Equipamentos mais avançados podem reproduzir a figura tridimensional virtual dos testemunhos, a partir das informações das paredes, por meio de imagens digitais, permitindo obter as orientações das estruturas geológicas. O TRH é um dispositivo para registro dos caminhos de percolação d’água em furos de sondagem. Ele marca, em uma tela permeável, colocada junto da parede do furo, a passagem de água com corante, injetada desde a superficie. Os caminhos de percolação ficam marcados na tela como faixas pintadas de 1 a $3 \mathrm{~cm}$ de largura.

A maior dificuldade associada a este método é a obtenção de informações representativas do sistema de fraturamento. No método estão implicitas, ainda, hipóteses de uniformidade das variáveis dos sistemas de fraturas, além de sua extensão infinita, quando, na realidade, estas grandezas são estatisticamente distribuidas de diferentes formas, como, por exemplo, o espaçamento que apresenta nos maciços uma distribuição exponencial; a abertura, uma distribuição log normal; a orientação, uma distribuição normal hemisférica, etc. (CELESTINO, 1986).

Os métodos de ensaios hidráulicos de campo, por outro lado, são baseados em resultados de ensaios de bombeamento ou injeção d’água, nos quais a influência individual dos vários parâmetros do sistema de fraturas se integram nos próprios resultados dos ensaios. Nestes métodos, a principal dificuldade que se interpõe é a determinação de um volume de ensaio que seja representativo do maciço rochoso, denominado de Volume Elementar Representativo (V.E.R.), cujo conceito é apresentado na Figura 20.

Com o aumento do volume do maciço, sua permeabilidade média varia bruscamente pela inclusão de novas fraturas ou de novas porções de matriz rochosa. A partir de certo volume, estas novas inclusões não mais interferem significativamente na média, sendo, então, definido o Volume Elementar Representativo. O V.E.R. deve ainda ser pequeno o bastante para que o gradiente hidráulico seja constante no seu interior e grande o suficiente para que todas as feições condicionantes, na escala do problema, sejam englobadas.

Caso não sejam atendidas estas condições, o meio não poderá ser assemelhado a um meio homogêneo equivalente, não sendo válidos, portanto, os preceitos estabelecidos pela Lei de Darcy.

Estudos efetuados por diversos autores (ex. LONG et al., 1982; LONG \& WITHERSPOON, 1985) têm demonstrado que, a partir de uma certa escala, certa 


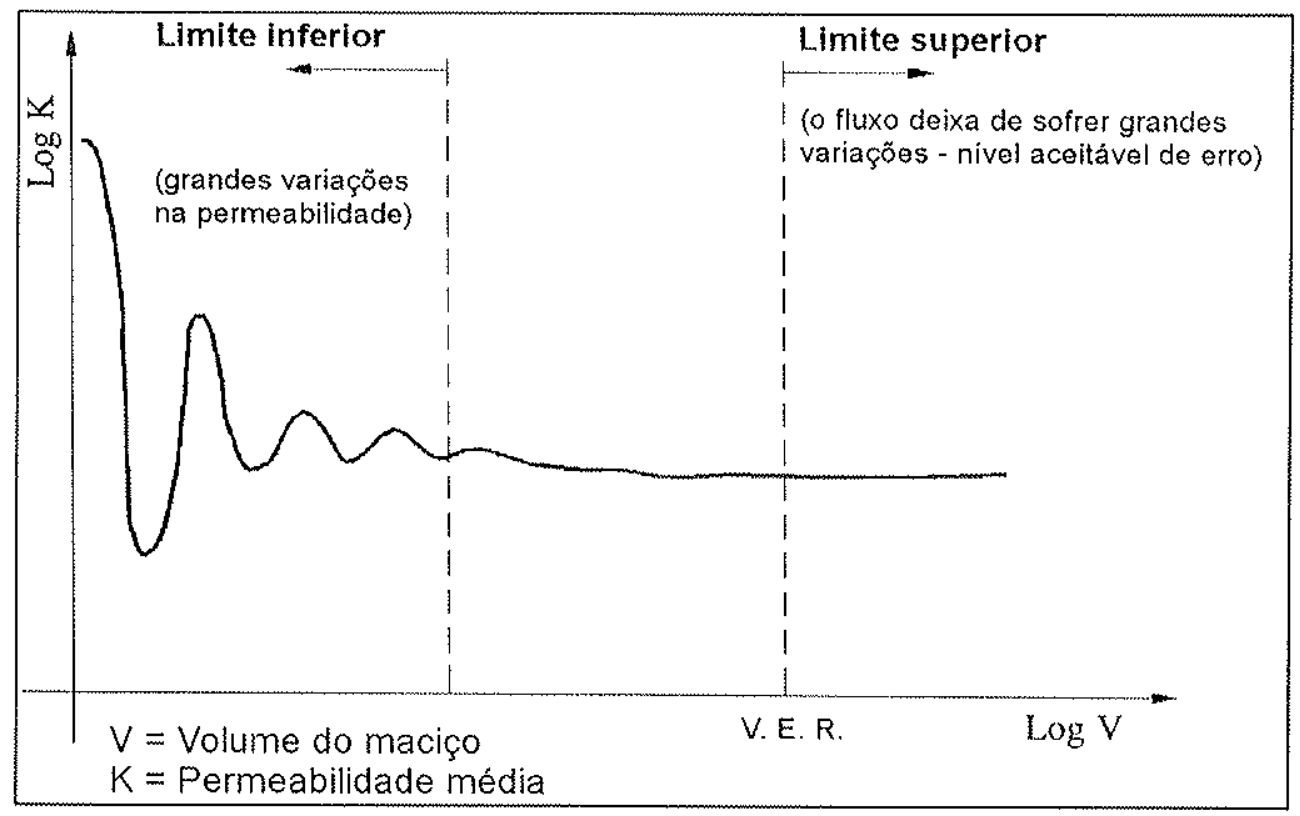

Figura 20 - Conceito de Volume Elementar Representativo (V.E.R.) (BEAR, 1972).

densidade de fraturas e valores relativos de condutividade hidráulica, é possível adotar a aproximação de maciço homogêneo equivalente.

Embora diversos métodos para determinação dos parâmetros hidráulicos de maciços rochosos tenham sido desenvolvidos, quase todos apresentam limitações, resultantes da própria dificuldade em se reproduzir a complexidade estrutural dos maciços, o que implica, muitas vezes, em simplificações necessárias ao equacionamento dos problemas mas que, nem sempre, correspondem à realidade.

Atualmente, o método mais promissor e que apresenta melhores resultados é o método de $\mathrm{HSIEH}$, que consiste na injeção ou bombeamento de água em um trecho de um furo e observação em trechos de furos circunvizinhos (Figura 21). O método baseia-se na solução geral do problema da variação de carga hidráulica com o tempo, em um ponto qualquer de um meio anisotrópico, causada pela injeção ou bombeamento de uma vazão constante em um outro ponto do mesmo meio. Para execução deste ensaio não se requer conhecimento prévio das direções principais do fraturamento. Os furos de ensaio podem ser executados em quaisquer direções e os volumes ensaiados podem ser controlados pela escolha do espaçamento entre os furos de injeção e os de observação. Não é necessária a elaboração de nenhuma hipótese, a "priori", sobre qualquer propriedade das fraturas. 0 método é capaz ainda de detectar a presença, nas proximidades da região ensaiada, de uma feição muito permeável, ou muito impermeável, não interceptada pelos furos de ensaio (QUADROS, 1992). 


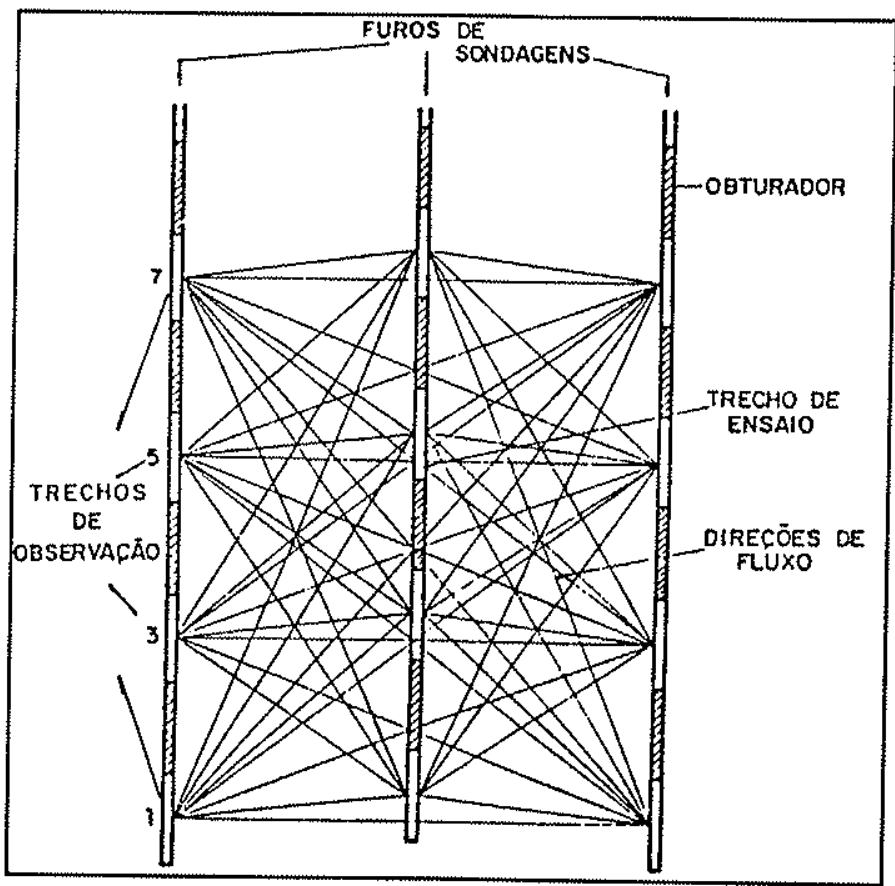

Figura 21 - Trajetórias de fluxo nos ensaios direcionais. Esquematização para três furos e quatro trechos de ensaios e observação (QUADROS, 1992).

Nos casos mais simples, e para avaliações mais grosseiras da permeabilidade de maciços rochosos, pode-se utilizar a seguinte equação:

$$
K_{M}=\frac{e}{l} K_{f}+K_{r} \quad \text { (equação 1) }
$$

sendo:

$K_{M}=$ permeabilidade do maciço rochoso;

e = abertura das fraturas;

$I$ = espaçamento entre fraturas;

$\mathrm{K}_{\mathrm{f}}=$ permeabilidade das fraturas;

$\mathrm{K}_{\mathrm{r}}=$ permeabilidade da matriz rochosa

A permeabilidade da matriz rochosa é, via de regra, muito baixa, podendo ser desprezada. Desta forma, a equação 1 pode ser reescrita da seguinte forma:

$$
K_{M}=\frac{g \cdot e^{3}}{12 \nu} \quad \text { (equação 2) }
$$


onde:

$\mathrm{g}=$ aceleração da gravidade

$v=$ viscosidade dinâmica da água

$\mathrm{Na}$ prática, a determinação da abertura das fraturas de maciços rochosos é extremamente dificil. Neste caso, o conceito de transmissividade ( $T=K . b$ ), determinada a partir de ensaios de bombeamento "in situ", pode ser usado, com vantagem, eliminando-se a necessidade da determinação imprecisa tanto de $(e)$ quanto de $\left(K_{\mathfrak{f}}\right)$. Admite-se que a espessura saturada do meio (b) corresponde à abertura equivalente das fraturas.

Em inúmeros casos práticos, a permeabilidade dos maciços é estimada a partir de ensaios pontuais de permeabilidade (perda d’água sob pressão, infiltração, bombeamento, etc.), obtendo-se valores de condutividade hidráulica equivalente. Mais recentemente, a utilização de obturadores duplos especiais tem possibilitado a realização de ensaios de perda d’água sob pressão em múltiplos estágios (QUADROS, 1992) e a determinação mais precisa dos parâmetros hidráulicos das fraturas.

\subsection{3 - Características hidrogeológicas do aqüífero cristalino da RMSP}

O domínio de rochas cristalinas da RMSP tem uma extensão da ordem de $6.599 \mathrm{~km}^{2}$, onde as condições predominantes de ocorrência das águas subterrâneas são de aqüifero livre, heterogêneo e anisotrópico (CEPAS, 1994).

Segundo avaliação da tendência dos potenciais hidrogeológicos do aqüífero cristalino da Região Metropolitana de São Paulo realizada por CEPAS (1994), as rochas granitóides de granulação variada e as rochas predominantemente gnáissicas (unidade PEgo - Figura 7) apresentam uma tendência relativamente alta de potenciais hidrogeológicos, em função do caráter rúptil predominantemente, e/ou manto de intemperismo, em geral, mais arenoso. Por outro lado, os micaxistos, com quartzitos e metassiltitos subordinados e as rochas metacarbonáticas, compõem o domínio da tendência média, devido ao caráter relativamente dúctil, sobretudo, em função da alta argilosidade do manto de intemperismo. Local e ocasionalmente, a presença dos corpos quartzíticos ou de rochas metacarbonáticas, podem resultar em poços de produtividade excepcional (superiores a $50 \mathrm{~m}^{3} / \mathrm{h}$ ). 
A espessura média do manto de intemperismo na RMSP é estimada em $50 \mathrm{~m}$ podendo atingir, local e ocasionalmente, valores de até $150 \mathrm{~m}$ (REBOUÇAS, 1992).

A capacidade especifica média dos poços profundos no aqüífero cristalino, conforme estudo do DAEE (1975), é de $0,34 \mathrm{~m}^{3} / \mathrm{h} . \mathrm{m}$, variando de 0,06 a $0,7 \mathrm{~m}^{3} / \mathrm{h} . \mathrm{m}$. Entretanto, devese notar que $80 \%$ dos poços apresentam um valor de capacidade especifica igual ou inferior à média. A vazão média dos poços é da ordem de $7 \mathrm{~m}^{3} / \mathrm{h}$, podendo atingir até $90 \mathrm{~m}^{3} / \mathrm{h}$, no entanto metade deles apresenta vazão igual ou inferior a $2 \mathrm{~m}^{3} / \mathrm{h}$.

Em geral, os coeficientes de condutividade hidráulica variam entre $10^{-6}$ a $10^{-7} \mathrm{~m} / \mathrm{s}$ no terço superior do perfil, e entre $10^{-3}$ a $10^{-4} \mathrm{~m} / \mathrm{s}$ na zona de transição entre a rocha alterada $e$ a rocha relativamente sã (REBOUÇAS \& CAVALCANTE, 1987). Nas zonas de rochas fraturadas os coeficientes de condutividade hidráulica situam-se nas ordens de grandeza da seção inferior do manto de intemperismo, devido ao preenchimento das feições lineares por esses produtos de alteração (CEPAS, 1994).

Segundo MENEGASSE (1991), nos metassedimentos do Grupo São Roque da porção noroeste da Grande São Paulo, as profundidades mais freqüentes dos poços tubulares situam-se entre 100 e $150 \mathrm{~m}$, com profundidades de entrada de água principalmente entre 50 e $100 \mathrm{~m}$. Já na região de Guarulhos, a profundidade média dos poços é de $193 \mathrm{~m}$, com principais entradas de água entre 150 a $210 \mathrm{~m}$ (DINIZ, 1996). 


\section{4 - MATERIAL E MÉTODOS}

\section{1 - Levantamento geológico}

O levantamento geológico se deu em três etapas distintas: levantamento de dados na literatura, interpretação fotogeológica e levantamentos de campo.

Na primeira etapa foi dada ênfase ao levantamento de mapas geológicos existentes que englobam a Região Metropolitana de São Paulo (RMSP) e seus arredores, destacandose, assim, os mapas de COUTINHO (1972) - escala 1:100.000, EMPLASA (1980) - escala 1: 100.000, IPT (1981b) - escala 1:500.000 e CEPAS (1984) - escala 1:50.000 (folha Mauá).

A etapa seguinte consistiu-se da análise de fotografias aéreas para o traçado dos contatos geológicos, na escala 1:10.000, de levantamento efetuado por BASE S.A. para ELETROPAULO, em 1986, e para o traçado de fraturas e falhas, na escala 1:40.000, de levantamento efetuado por TERRAFOTO S.A. para EMPLASA, em 1977. O traçado das fraturas e falhas teve como base a metodologia desenvolvida por SOARES \& FIORI (1976), através do estudo dos elementos texturais de drenagem que, quando retilineos e em arco, constituem as lineações de drenagem. O resultado deste trabalho foi o mapa de lineamentos apresentado no capitulo 5 (item 5.1.2).

Os levantamentos de campo foram realizados em diversas fases ao longo desta pesquisa e tiveram por objetivos a aferição dos dados levantados na literatura e daqueles obtidos da fotointerpretação, além do levantamento de dados estruturais. Foram cadastrados 15 (quinze) afloramentos que, na sua maioria, constituíam exposições de rochas extremamente alteradas, com exceção daqueles afloramentos de granito-gnaisse em cavas de pedreiras, na porção norte da área, onde se observa a rocha sã. Além da descrição dos afloramentos foram coletadas algumas amostras de rocha para eventual análise macroscópica em laboratório. No levantamento de dados estruturais foram tomadas medidas de atitudes de estruturas planares (bandamento, xistosidade, fraturas e falhas) e estruturas lineares (estrias) das rochas, com o uso de uma bússola Brunton. Os dados estruturais obtidos foram convertidos para o sistema de leitura Clar e são apresentados no Anexo 1. Para o tratamento destes dados foram utilizados os "softwares" stereoNet (versão 2.06 - 1992-1993) - diagramas de Schmidt-Lambert e diagramas de contorno, ROSAC (desenvolvido no Agrupamento de Geologia Aplicada a Obras do IPT) - diagramas de rosáceas e TRADE - tratamento de falhas pelo Método de Angelier. 


\section{2 - Levantamento do uso e ocupação territorial}

Diante da impossibilidade de utilização de imagens de satélite para o levantamento de uso e ocupação, por razões de incompatibilidade de escalas, utilizou-se, na etapa inicial, fotografias aéreas na escala 1:5.000, de levantamento efetuado por BASE S.A. para PMSP. RESOLO, em 1996, através das quais foi elaborado o mapa de uso e ocupação por IEZZI (1999), que será apresentado neste estudo (capitulo 5 - item 5.2).

Em seguida, foi realizado um levantamento de dados na literatura visando principalmente o cadastramento de fontes potenciais de contaminação da água subterrânea. Neste sentido, destacou-se o levantamento ambiental realizado pela PREFEITURA DO MUNICIPIO DE SÃO PAULO - SECRETARIA MUNICIPAL DO VERDE E DO MEIO AMBIENTE (1996), na área denominada "Passagem Funda" (situada dentro da área Fazenda do Carmo), que relata atividades potencialmente poluidoras e a disposição inadequada de resíduos sólidos. Este levantamento foi complementado com trabalhos de campo que identificaram e catalogaram novos pontos de disposição irregular de resíduos sólidos, distribuídos em toda a área de estudo. Durante os trabalhos de campo também foram cadastradas as empresas e estabelecimentos existentes na área, totalizando 126 (cento e vinte e seis) pontos (Anexo 2). Estes, juntamente com as fontes potenciais, tiveram suas localizações registradas por um aparelho GPS ("Ground Positioning System") - Garmin GPS II plus, para posterior plotagem em mapa.

\section{3 - Levantamento hidrogeológico}

\subsection{1 - Cadastramento de poços e pontos d’água}

Esta etapa compreendeu o levantamento de campo de poços tubulares, cacimbas (poços escavados) e fontes existentes na região, através de diversas visitas realizadas em quase todas as indústrias, estabelecimentos e propriedades, como sítios e chácaras da área. No total foram cadastrados 131 (centro e trinta e um) poços, sendo 98 (noventa e oito) cacimbas e 33 (trinta e três) poços tubulares, além de 6 (seis) fontes.

As informações relacionadas aos poços tubulares foram obtidas principalmente através de informações verbais dos proprietários dos poços e, secundariamente, por meio de fichas técnicas (nove) cedidas por alguns proprietários e por algumas empresas perfuradoras que operaram na região, como a JUNDSONDAS (Jundiai-SP), TRIGILL (Santo André-SP) e HIDROGESP (São Paulo-SP). OS motivos de se obter tão poucas fichas 
técnicas é que muitos proprietários alegaram não as possuírem, em virtude dos poços terem sido construidos pelas empresas anteriores e que algumas empresas perfuradoras não concordaram em ceder os dados alegando questões de ética profissional. Além disso, no geral, as fichas técnicas apresentaram mais dados sobre os aspectos construtivos dos poços do que referentes à produção dos mesmos, sendo que em algumas delas os perfis geológicos deixaram dúvidas até mesmo quanto às litologias perfuradas.

No caso das cacimbas, as profundidades, niveis estáticos e diâmetros da maioria dos poços foram obtidos "in situ", usando-se uma trena e um medidor de nível. Nesta fase também foram coletadas informações sobre os aspectos construtivos das cacimbas, através de observações diretas, e sobre o uso das águas e vazões de explotação dos poços.

Procurou-se plotar a localização dos poços visitados por meio dos mapas e fotografias aéreas disponiveis, utilizando-se as coordenadas obtidas pelo GPS somente nos casos em que isto não era possivel.

Numa ordem inversa, após o cadastramento de poços no campo, foi feita uma consulta no banco de dados do DAEE, que revelou a existência de apenas um poço tubular na área de estudo (poço 36), evidenciando assim a falta de diálogo entre as empresas perfuradoras e este órgão.

Dentre os poços levantados, alguns já haviam sido cadastrados por CEPAS (1994) - 1 (um) poço tubular e pela PREFEITURA DO MUNICIPIO DE SÃO PAULO - SECRETARIA MUNICIPAL DO VERDE E DO MEIO AMBIENTE (1996) - 3 (três) poços tubulares e cinco cacimbas, os quais foram visitados neste cadastramento.

\subsection{2 - Análises químicas}

As análises químicas das águas neste estudo foram realizadas em duas fases, com objetivos distintos. $\mathrm{Na} 1^{\text {a }}$ fase (realizada em dezembro/98) o objetivo foi avaliar a qualidade das águas, sendo analisadas 27 (vinte e sete) amostras (23 de poços cacimbas, 3 de poços tubulares e 1 de fonte). $\mathrm{Na} 2^{\mathrm{a}}$ fase (realizada em agosto/setembro/99) foram analisadas 11 (onze) amostras de poços cacimbas dentre aquelas analisadas na $1^{\text {a }}$ fase, com o objetivo de verificar o grau de confiabilidade dos resultados obtidos, já que na primeira fase não foram coletadas amostras duplicatas. As 11 (onze) amostras correspondem a 6 (seis) poços que foram amostrados duas vezes, com exceção de um deles. 
A seleção dos pontos de amostragem procurou seguir dois critérios, na $1^{\text {a }}$ fase, conforme discriminados a seguir, enquanto na $2^{\text {a }}$ fase a seleção foi aleatória:

a) proximidade de locais de disposição de residuos industriais e domésticos no solo, para investigação quanto ao potencial poluidor;

b) distribuição uniforme dos pontos, de modo a representar toda a área.

Em ambas as fases os elementos analisados foram os seguintes:

- cátions: $\mathrm{Ag}^{+}, \mathrm{Al}^{3+}, \mathrm{Ba}^{2+}, \mathrm{Ca}^{2+}, \mathrm{Cd}^{2+}, \mathrm{Cr}_{\text {total }}, \mathrm{Cu}^{2+}, \mathrm{Fe}_{\text {total }}, \mathrm{K}^{+}, \mathrm{Mg}^{2+}, \mathrm{Mn}^{2+}, \mathrm{Na}^{+}, \mathrm{Ni}^{2+}, \mathrm{Pb}^{2+}$, $\mathrm{Sr}^{2+}, \mathrm{Zn}^{2+}$

ânions: $\mathrm{Br}^{-}, \mathrm{Cl}^{*}, \mathrm{~F}^{*}, \mathrm{NO}_{2}{ }^{-}, \mathrm{NO}_{3}{ }^{-}, \mathrm{PO}_{4}{ }^{3-}, \mathrm{SO}_{4}{ }^{2-}$.

Os cátions $\mathrm{Cd}^{2+}, \mathrm{Cr}_{\text {total }}, \mathrm{Ni}^{2+}, \mathrm{Pb}^{2+}$ foram escolhidos por estarem presentes nos principais componentes químicos de tintas e solventes, usados amplamente nas atividades industriais potencialmente poluidoras cadastradas na área.

As análises quimicas foram realizadas no Laboratório de Hidrogeoquímica /l do Centro de Pesquisas de Água Subterrânea da Universidade de São Paulo (CEPAS-USP), utilizando-se os seguintes métodos e aparelhos, respectivamente:

- $\mathrm{Na}^{+}, \mathrm{K}^{+}$: fotometria de chama (Fotômetro B 262 da Micronal);

- ânions: cromatografia liquida (DIONEX 2010i);

- os demais cátions: espectrofotometria (Absorção Atômica CG AA 7000 BCe).

As técnicas de coleta e preservação das amostras de água se basearam principalmente na metodologia proposta por CETESB (1987), conforme descritas a seguir.

Idealmente, no caso de poços ou piezômetros em repouso, é recomendado o esgotamento do poço duas a três vezes o seu volume para evitar a coleta de amostras não representativas do aqüífero, estagnadas e/ou contaminadas, entretanto, visto que os poços amostrados neste estudo estão em constante uso e que os volumes de água são reduzidos, as amostras foram coletadas após um período de cinco minutos de bombeamento.

No caso dos poços cacimbas, as amostras foram coletadas através das mangueiras acopladas às bombas elétricas, com exceção de dois poços na primeira fase e dois na segunda fase e, no caso dos poços tubulares (três poços), através de torneiras ou 
tubulações nas entradas de caixas d'águas. Em ambos os casos, utilizou-se para a coleta da água os próprios frascos onde foram armazenadas as amostras. A técnica empregada para coletar as amostras dos poços não bombeados na primeira fase (pontos 25 e 87) foi o uso de um amostrador metálico, cilindrico, que possui na sua base uma válvula esférica que veda a passagem da água após o enchimento do amostrador. Na segunda fase foi usado um amostrador "bailer" de polietileno, descartável, para a coleta nos pontos 71 e 91.

Os frascos utilizados para o armazenamento das amostras foram frascos de polietileno, novos, de $125 \mathrm{~mL}$, por serem os mais recomendados para os parâmetros físicoquímicos analisados. $O$ volume de água coletado, por amostra, para as análises de cátions foi de $125 \mathrm{~mL}$ e para as de ânions de $115 \mathrm{~mL}$, aproximadamente, conforme instrução do laboratório.

Após a coleta, cada amostra foi devidamente identificada através de uma etiqueta contendo o número da amostra, ponto de amostragem, parâmetros a serem analisados e nome do responsável pela coleta.

No intervalo de tempo entre a coleta de amostras d'água e a realização das análises no laboratório, podem ocorrer modificações físico-químicas, biológicas e radiológicas na amostra, que alteram as caracteristicas da água amostrada. Para evitar, diminuir ou retardar essas modificações, faz-se necessário o uso de técnicas adequadas de preservação e armazenamento das amostras d'água subterrânea (SANTOS, 1997). Desta forma, as técnicas de preservação de amostras empregadas neste estudo foram: acidificação, refrigeração e congelamento.

Para acidular as amostras foi utilizado o ácido nítrico concentrado - $16 \mathrm{~N}(3$ a 4 gotas por amostra, conforme instrução do laboratório), adicionando-o à amostra imediatamente após a coleta. Esta técnica foi aplicada para a preservação dos cátions, exceto o $\mathrm{Na}^{+} \mathrm{e} \mathrm{K}^{+}$. A acidulação propicia a queda no valor de $\mathrm{pH}$ para o intervalo entre 1 e 2 evitando desta maneira, a precipitação ou a adsorção, por exemplo, de alguns metais na superfície do recipiente.

Para a preservação dos ânions, as técnicas empregadas foram a refrigeração e o congelamento. As amostras foram mantidas sob refrigeração, numa caixa de isopor com gelo, desde a coleta até a chegada ao laboratório, onde passaram imediatamente para o freezer para serem congeladas, até serem analisadas. Esta última técnica propicia aumentar - intervalo entre a coleta e a análise da amostra, sem comprometer o resultado das análises. 
Para evitar qualquer tipo de contaminação é de fundamental importância a limpeza dos frascos e material de coleta, assim, antes da coleta, o coletor foi lavado com água deionizada e posteriormente com a própria água do poço, aplicando-se este último procedimento também aos frascos e tampas.

Em função de modificações nas condições físicomquímicas que podem ocorrer nas amostras de água durante a coleta, é necessário que alguns parâmetros como pH, Eh, temperatura, condutividade elétrica, alcalinidade, etc. sejam obtidos em campo. Assim, tal procedimento foi adotado neste estudo, utilizando-se os seguintes equipamentos e materiais:

- para leitura do pH e Eh: pHmetros (WTW - pH/mV Hand Held Meter pH 330/340) e (ORION - Quikcheck 106);

- para medição da temperatura e da condutividade elétrica: condutivímetros (WTW Conductivity Hand Held Meter LF 330/340) e (ORION - Quikcheck 116);

- para a determinação da alcalinidade: copos plásticos descartáveis, conta-gotas, indicador misto (verde de bromo cresol + vermelho de metila) e ácido sulfúrico $(0,1070 \mathrm{~N})$.

Os eletrodos e os frascos utilizados para a determinação destes parâmetros foram devidamente lavados com água deionizada e enxugados com papel absorvente, a cada troca de amostra, para evitar contaminação entre elas. Além disso, as determinações foram feitas em aliquotas de amostra separadas daquelas enviadas ao laboratório, para evitar o risco de contaminação.

As amostras nas quais não constam estes parâmetros é devido ou a problemas com os equipamentos ou ao fato destes últimos não estarem disponiveis em alguns dias de campo.

Deve-se ressaltar também, que a alcalinidade das amostras coletadas na fa fase foi determinada em laboratório, enquanto as da $2^{\mathrm{a}}$ fase, em campo. O método utilizado para a determinação da alcalinidade em ambas as fases foi o de Titulação Alcalinimétrica Completa (TAC), e os valores obtidos, neste caso, corresponderam à alcalinidade de bicarbonato, visto que para águas com $\mathrm{pH}<8,3$ a alcalinidade de bicarbonato coincide com a alcalinidade total.

Os resultados das análises da primeira fase foram obtidos num periodo de 40 a 120 dias após a coleta das amostras e, da segunda fase, após 42 a 55 dias. 


\section{5 - TRABALHOS REALIZADOS}

\section{1 - Levantamento geológico}

\subsection{1 - Caracterização geológica da área}

De acordo com os trabalhos de investigação geológica de campo realizados nesta pesquisa, o substrato rochoso da área de estudo é formado basicamente por três grupos de rocha: filitos e xistos (PEf), granito-gnaisse (PEgo) e sedimentos quaternários (Qa) - Figura 22.

Os filitos e xistos são os litotipos predominantes, ocupando quase $2 / 3$ da área. Em todos os pontos onde foram observadas estas rochas, o grau de intemperismo era bem avançado, de modo que foram descritos como saprolitos. O aspecto mais caracteristico desses afloramentos é o de espessos pacotes de rochas intemperizadas de ampla distribuição lateral (Figura 23), que atingem localmente (afloramento 7) até $20 \mathrm{~m}$ de espessura.

De um modo geral, esses saprolitos apresentam coloração cinza a marrom, variando, localmente, de vermelho a roxo, granulação fina e são ricos em micas (principalmente muscovita). Localmente (afloramento 4), a coloração cinza mais escura sugere a presença de grafita. A estrutura foliada é marcada por uma forte xistosidade (com exceção do afloramento 5), de direção $\mathrm{NE}$, concordante com a tendência regional e, geralmente, apresenta-se ondulada.

Paralelamente à xistosidade, ocorrem intercalações de bandas quartzíticas de espessuras variáveis, milimétricas a decimétricas (até $30 \mathrm{~cm}$ ), localmente segmentadas em forma de "boudins" (afloramento 3), bandas de composição granítica de espessuras centimétricas ( 1 a $5 \mathrm{~cm}$ ) - afloramento 5 , e bandas de composição micácea e coloração preta (afloramento 4). Subordinadamente, ocorrem ainda camadas quartzíticas de espessuras centimétricas discordantes à xistosidade (afloramento 3 ).

No mapa geológico (Figura 22) as rochas que ocorrem na porção meridional da área foram mapeadas por CEPAS (1994) como quartzitos, porém os afloramentos 6,7 e 8 mostram a ocorrência de filitos e xistos com intercalações de bandas quartzíticas, fortemente intemperizados, iguais aos aflorantes no restante da área, por isso serão considerados como pertencentes à unidade PEf. Em contrapartida, as rochas metabásicas (PEa) apresentadas na porção sudeste do mapa geológico não foram observadas em campo nesta pesquisa, porém deve ser lembrado que atualmente o nível de ocupação é 


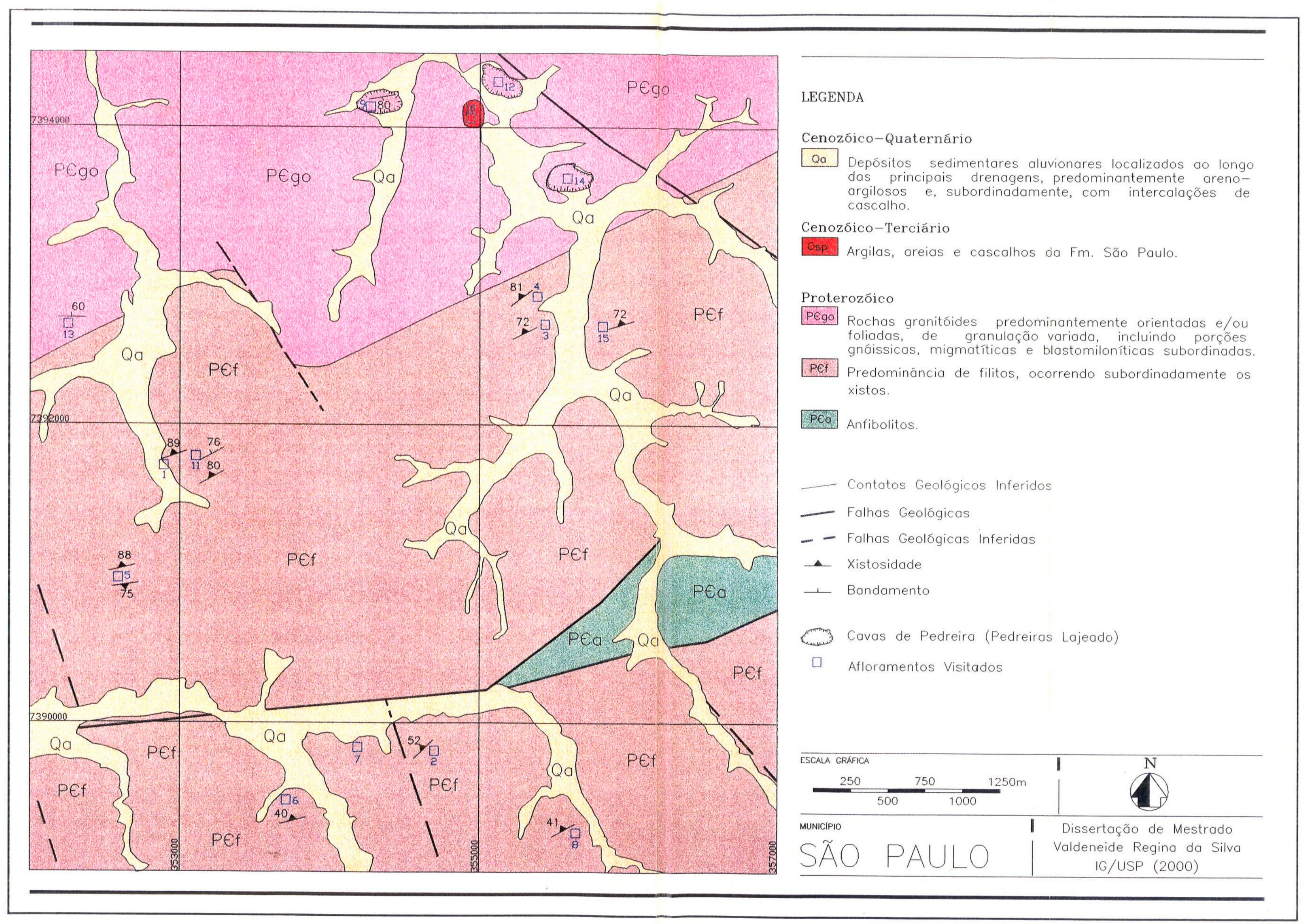

Figura 22- Mapa geológico da área de estudo (modificado de CEPAS, 1994). 


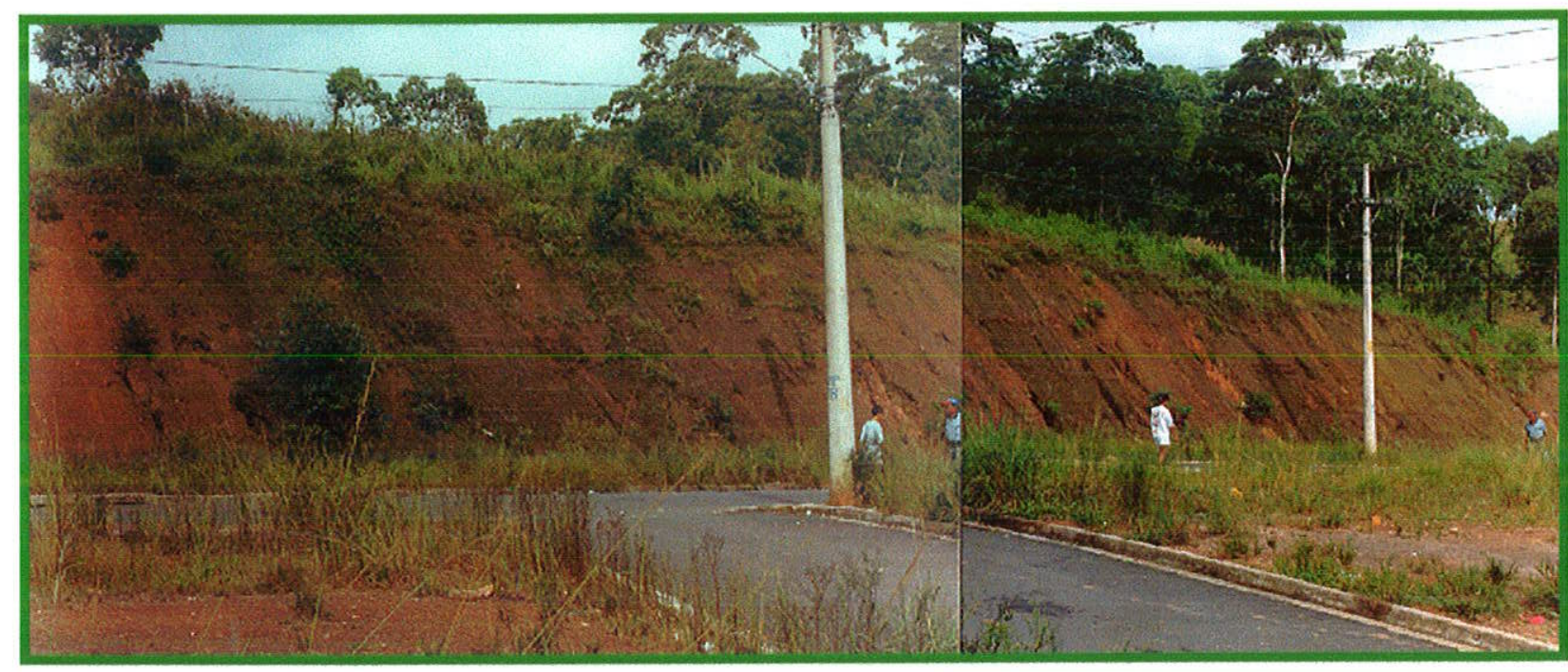

Figura 23 - Vista geral de perfil de intemperismo de xisto e/ou filito, num corte de estrada (afloramento 3).

muito maior do que na época daqueles mapeamentos, reduzindo, assim, o número de afloramentos.

$\mathrm{Na}$ porção setentrional da área (Figura 22) ocorre o granito-gnaisse, observado principalmente em cavas de pedreiras (afloramentos 9, 12 e 14), que explotam a rocha para a produção de pedra britada. Nestes afloramentos, o granito-gnaisse apresenta estrutura levemente bandada, evidenciada pela ocorrência de micas (biotita e muscovita) em níveis escuros intercalados a níveis claros formados por quartzo e feldspatos. As micas encontram-se orientadas nos níveis escuros desenvolvendo uma foliação paralela ao bandamento composicional e à xistosidade dos filitos e xistos. A rocha possui coloração cinza clara, granulação média e exibe diversos veios decimétricos de coloração esbranquiçada (composição quartzo + muscovita), de espessura variável, milimétrica a decimétrica $(0,3 \mathrm{~cm}$ a $15 \mathrm{~cm})$, que interceptam uns aos outros. Além disso, foi observado um bolsão pegmatítico (afloramento 14) formado por cristais centimétricos (até $2 \mathrm{~cm}$ ) de feldspato e muscovita. O solo produzido por essa rocha possui coloração rosada, textura areno siltosa e pequenas espessuras (Figura 24). Segundo pesquisa realizada por $\mathrm{CDH}$ (1987), na área Fazenda do Carmo, os solos produzidos por essa rocha possuem granulometria variável, com predominância das frações areno-argilosas e espessuras que podem ultrapassar 18 (dezoito) metros.

Próximo à uma cava de pedreira foram observados sedimentos, pertencentes à Bacia de São Paulo (afloramento 10), provavelmente da Formação São Paulo devido sua ocorrência pontual, caracterizados como argilito de coloração amarela, bastante intemperizado, evoluindo para um solo de coloração vermelha a vermelha alaranjada, 


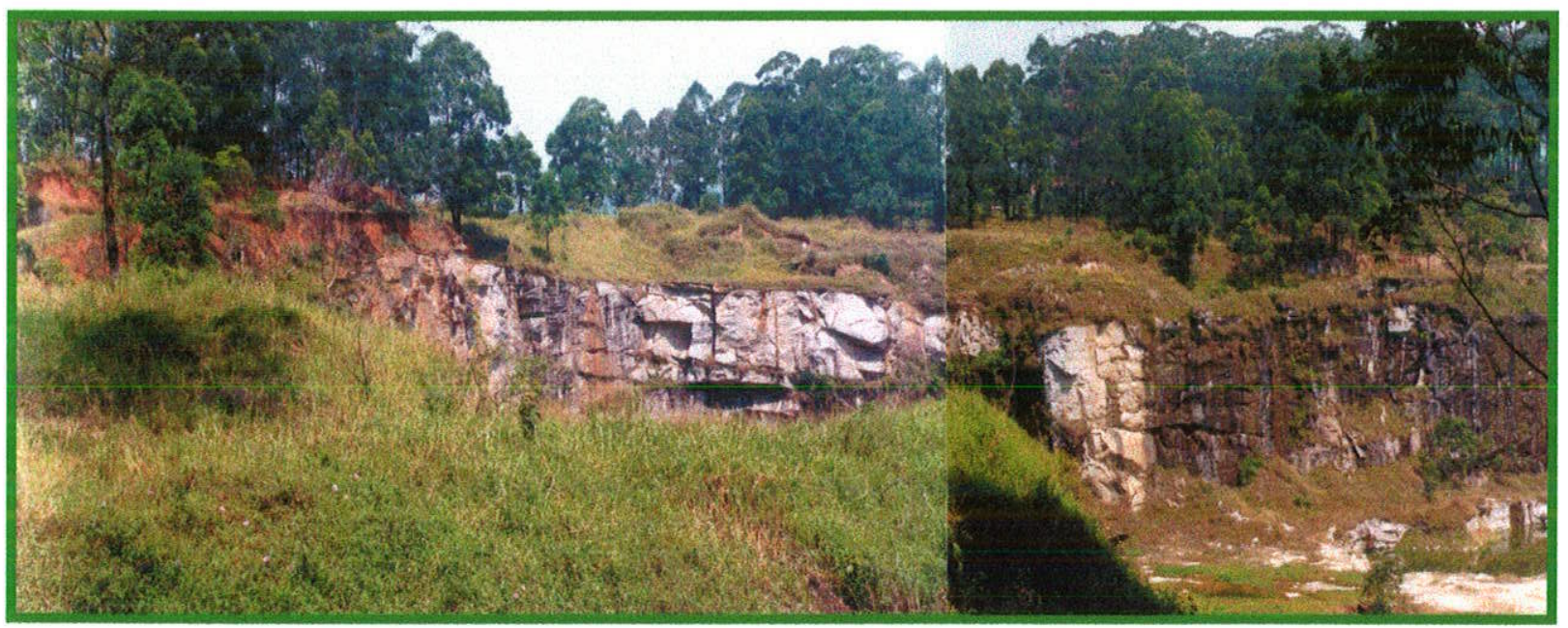

Figura 24 - Afloramento de granito-gnaisse, em cava de pedreira, mostrando a pequena espessura do manto de intemperismo desenvolvida por este litotipo (afloramento 9). Altura aproximada do afloramento $=8$ a 10 metros.

contendo argila e quartzo. Como sua ocorrência na área é localizada, aparece no mapa geológico (Figura 22) como uma pequena mancha.

Quanto às unidades quaternárias, os sedimentos coluvionares foram de fácil reconhecimento no campo (afloramento 6), pois geralmente formam uma linha de seixos no contato com os solos de alteração das rochas. As espessuras observadas desses sedimentos foram inferiores a $1,0 \mathrm{~m}$. Os sedimentos aluvionares não foram descritos em campo, contudo, seus contatos foram definidos com base nas curvas de nível próximas às calhas das drenagens, observadas no mapa topográfico. Segundo CDH (1987), estas unidades ocorrem, na área Fazenda do Carmo, principalmente como aluviões junto às calhas das drenagens mais significativas, em regiões de planície. Estes aluviões são constituídos por areias e argilas, sendo o material argiloso o de maior expressão em área e volume, apresentando profundidades prováveis de até 4 (quatro) metros. Os sedimentos coluvionares ocorrem capeando os solos de alteração dos granitos, xistos e filitos em camadas de espessura variável, que raramente ultrapassam 2 (dois) metros.

\subsection{2 - Análise estrutural}

Conforme descrito no capítulo 4 (item 4.1), a primeira etapa do levantamento de dados estruturais foi o traçado das lineações de drenagem em fotografia aérea (dispostos aqui quase sempre em linha reta), que serão aqui denominadas de lineamentos, referindo-se a 
traços de fraturas (juntas e falhas). Os lineamentos fotointerpretados estão representados na Figura 25.

Em seguida, usando o mapa de lineamentos como base, foram elaborados os diagramas de rosáceas que indicam as direções predominantes dos lineamentos, separados por litotipos, em relação à somatória dos seus comprimentos (Figura 26 a) e em relação apenas ao número de lineamentos (Figura 26 b).

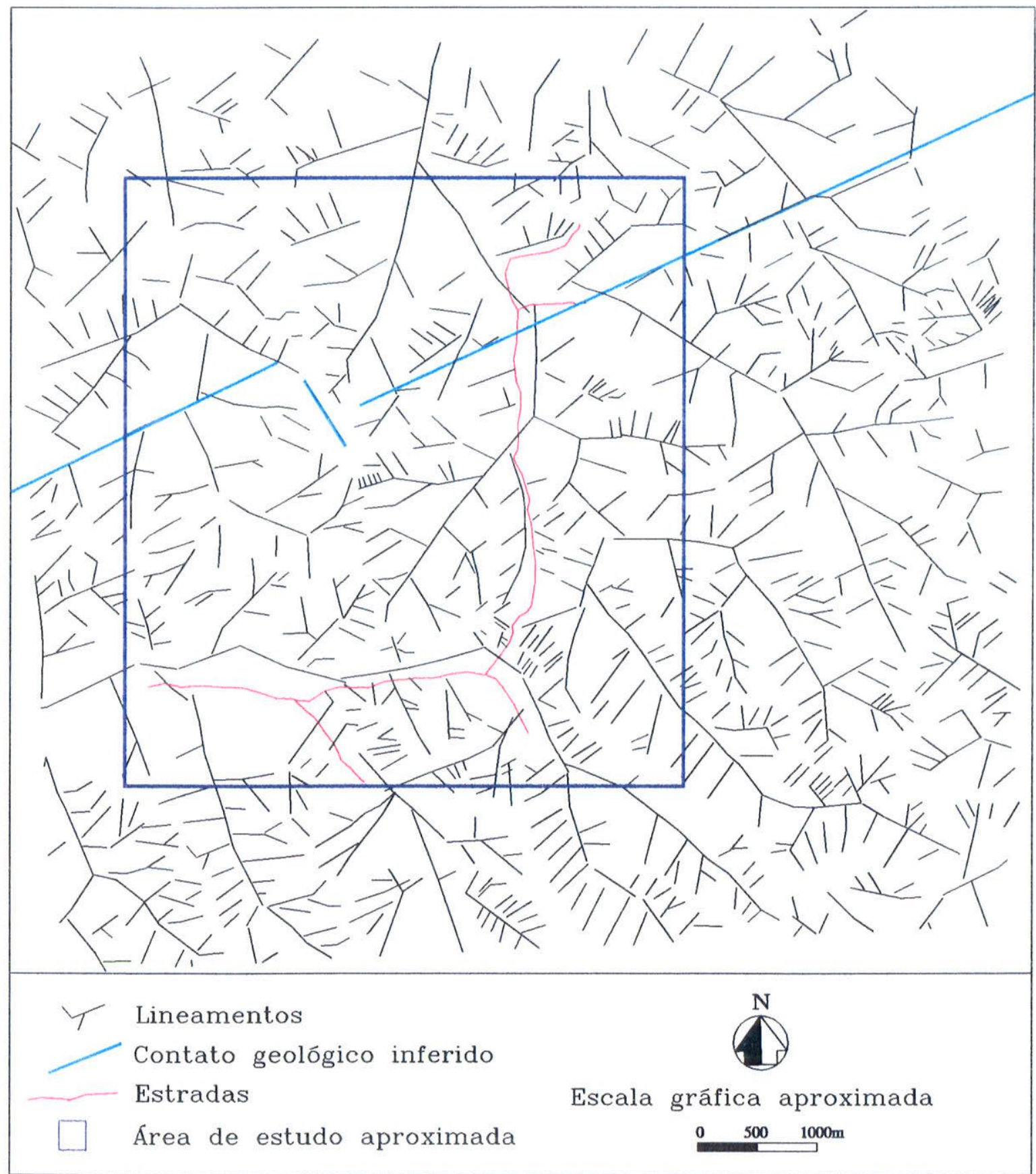

Figura 25 - Mapa de lineamentos a partir de fotografia aérea (foto 331, faixa $8 \mathrm{C}$ ). 
GRANITD-GNAISSE

RUSACEA - TAMANHI DE LINEAMENTUS

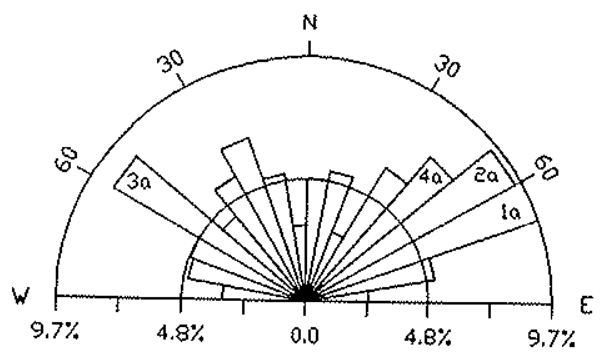

N.LINEAMENTDS $=280$

CDMPRIMENTU TOTAL $=79478.569$

FREQ. MAXIMA (EM NUMERQ) $=27(9.6 \%)$

FREQ. MAXIMA 〈CUMPRIMENTD〉 $=7719.539 \mathrm{~m}$ (9.7\%)

INTERVAL[] ANGULAR $=10$ graus
FILITOS E XISTOS

RUSACEA - TAMANHI DE LINEAMENTIDS

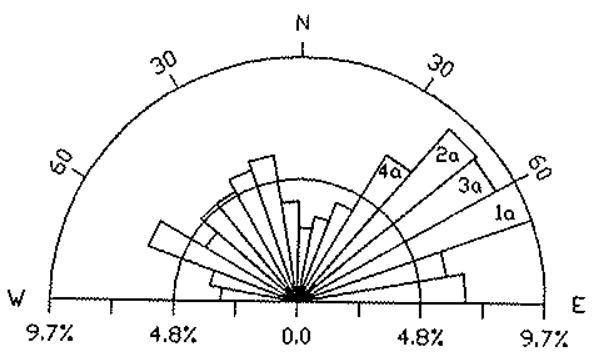

N.LINEAMENTOS $=8.36$

FREQ. MAXIMA 〈COMPRIMENTU〉 $=20738.940 \mathrm{~m}\langle 9.7 \%$

CDMPRIMENTD TQTAL. $=213409,310 \mathrm{~m}$

FREQ. MAXIMA 〈EM NUMERC]〉 $=86(10.2 \%$

INTERVALI ANGUL,AR $=10$ graus

RQSACEA - NUMERD DE LINEAMENTOS

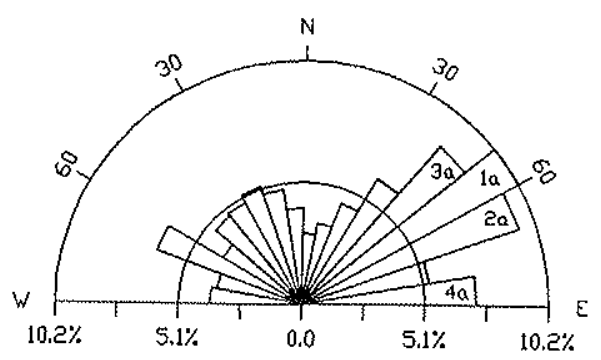

Figura 26 - Diagramas de rosáceas mostrando as direções predominantes dos lineamentos em relação ao tamanho (a) e ao número (b) de lineamentos.

A análise dos diagramas referentes ao tamanho dos lineamentos (Figura 26 a) revela que dentre as 4 (quatro) principais familias de fraturas fotointerpretadas, entre os dois grupos de rocha, existe uma coincidência direta entre as primeiras famílias de ambos os grupos, enquanto que as demais são apenas próximas entre si, com exceção das $3^{\text {as }}$ familias.

Por outro lado, ao se comparar as principais famílias destes diagramas (Figura 26 a) com os maiores lineamentos individuais nos granitos (N5-45E e N10-40W) e nos filitos (N10$45 \mathrm{~W}$ e N30-80E) (Figura 25), nota-se a ausência de relação entre elas, especialmente com aqueles grandes lineamentos de direção NW nos filitos. Isto indica que os maiores lineamentos individuais, apesar de terem tamanhos significativos, não representam as direções de maior anisotropia das rochas, que são dadas pela somatória dos comprimentos dos lineamentos. Estas direções de maior anisotropia são no caso dos granitos, N50-70E, e no caso dos filitos, N60-70E e N40-50E, segundo as duas primeiras familias (Figura 26 a). 
Isto implica que os lineamentos menores (Figura 25) são, no mínimo, mais representativos em termos de número de lineamentos (Figura 26 b).

Nestes últimos diagramas (Figura 26 b), ao se comparar as direções das principais famílias de fraturas entre os dois litotipos, observa-se uma coincidência direta entre as $2^{\text {as }} e$ as $3^{\text {as }}$ famílias, enquanto as primeiras são de direções opostas.

De posse desses dados partiu-se para os trabalhos de campo realizados em afloramentos, onde foram medidas as estruturas planares (bandamento composicional, xistosidade, fraturas e falhas) e estruturas lineares (estrias) das rochas. Essas medidas foram lançadas em diagramas de Schmidt-Lambert e diagramas de contorno, separados por estruturas e por tipo de rocha (granito-gnaisse; filitos e xistos), conforme apresentados nas Figuras 27 a 31.

Analisando a Figura 27, nota-se que o bandamento composicional e a xistosidade são sub-paralelos, com direção para NE variando entre $30^{\circ}$ e $90^{\circ}$ (Anexo 1). Esta direção se assemelha com as principais familias de fraturas fotointerpretadas (Figura 26 a e b), nos filitos, o que pode estar indicando que muitos lineamentos fotointerpretados como fraturas, especialmente os menores, correspondem a traços de xistosidade. Esta hipótese é reforçada quando se compara as direções das principais familias de fraturas medidas no campo (Figuras 28 a 31), conforme indicadas a seguir, e a direção da xistosidade.

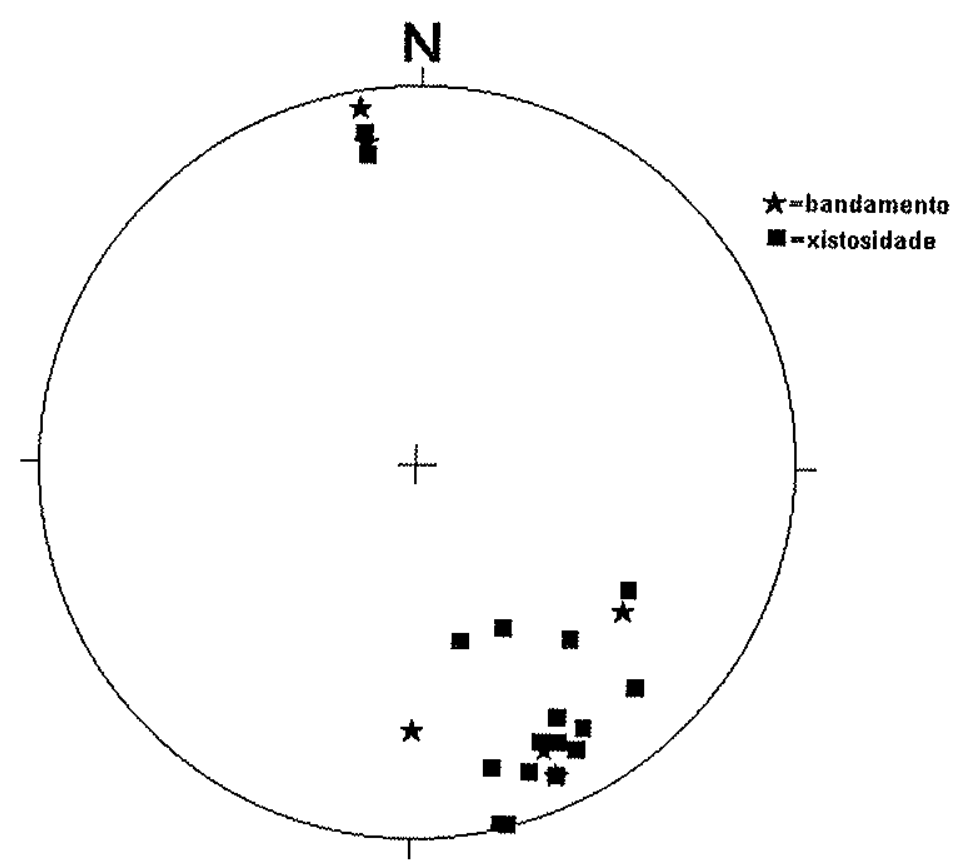

Figura 27 - Diagrama de Schmidt-Lambert (hemisfério inferior) com os polos dos planos de bandamento do granito-gnaisse e dos planos de xistosidade dos filitos e xistos. 


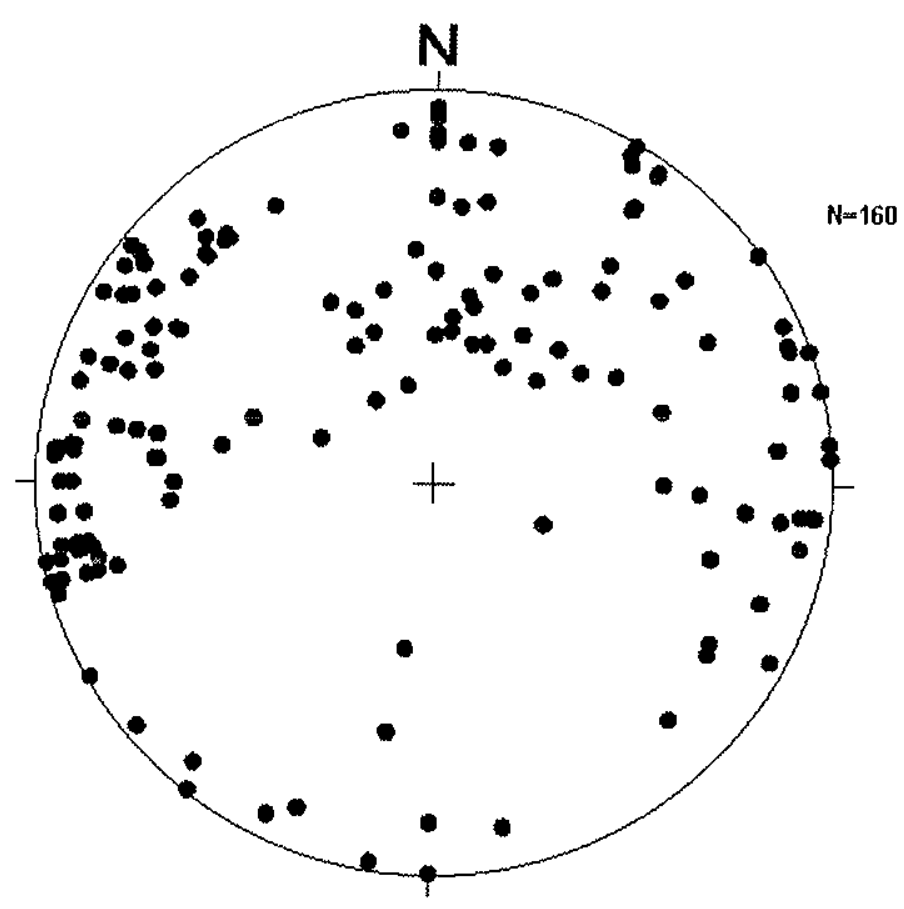

Figura 28 - Diagrama de Schmidt-Lambert (hemisfério inferior) com os polos dos planos das fraturas medidas no granito-gnaisse.

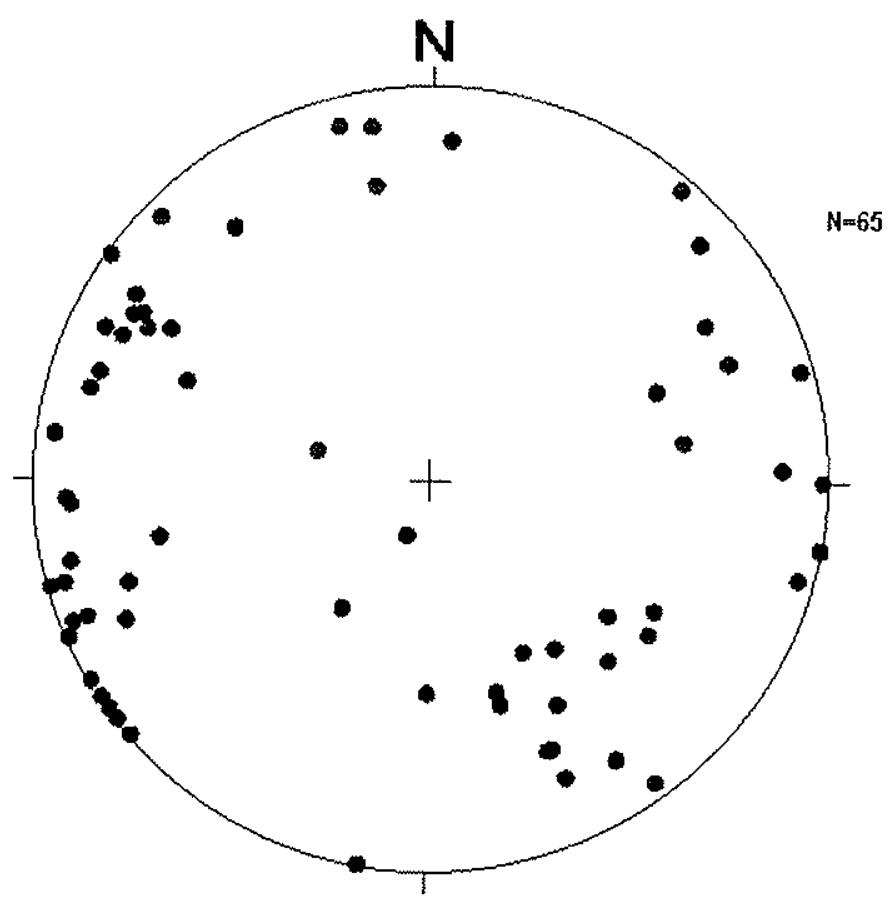

Figura 29 - Diagrama de Schmidt-Lambert (hemisfério inferior) com os polos dos planos das fraturas medidas nos filitos e xistos. 
Valores das linhas de isodensidades

\begin{tabular}{|c|c|}
\hline Linhas & $\%$ \\
\hline 5 & 3.13 \\
\hline 6 & 3.75 \\
\hline 7 & 4.38 \\
\hline 8 & 5.00 \\
\hline 9 & 5.63 \\
\hline 10 & 6.25 \\
\hline 11 & 6.88 \\
\hline 12 & 7.50 \\
\hline 13 & 8.13 \\
\hline 14 & 8.75 \\
\hline 15 & 9.38 \\
\hline 16 & 10.00 \\
\hline
\end{tabular}

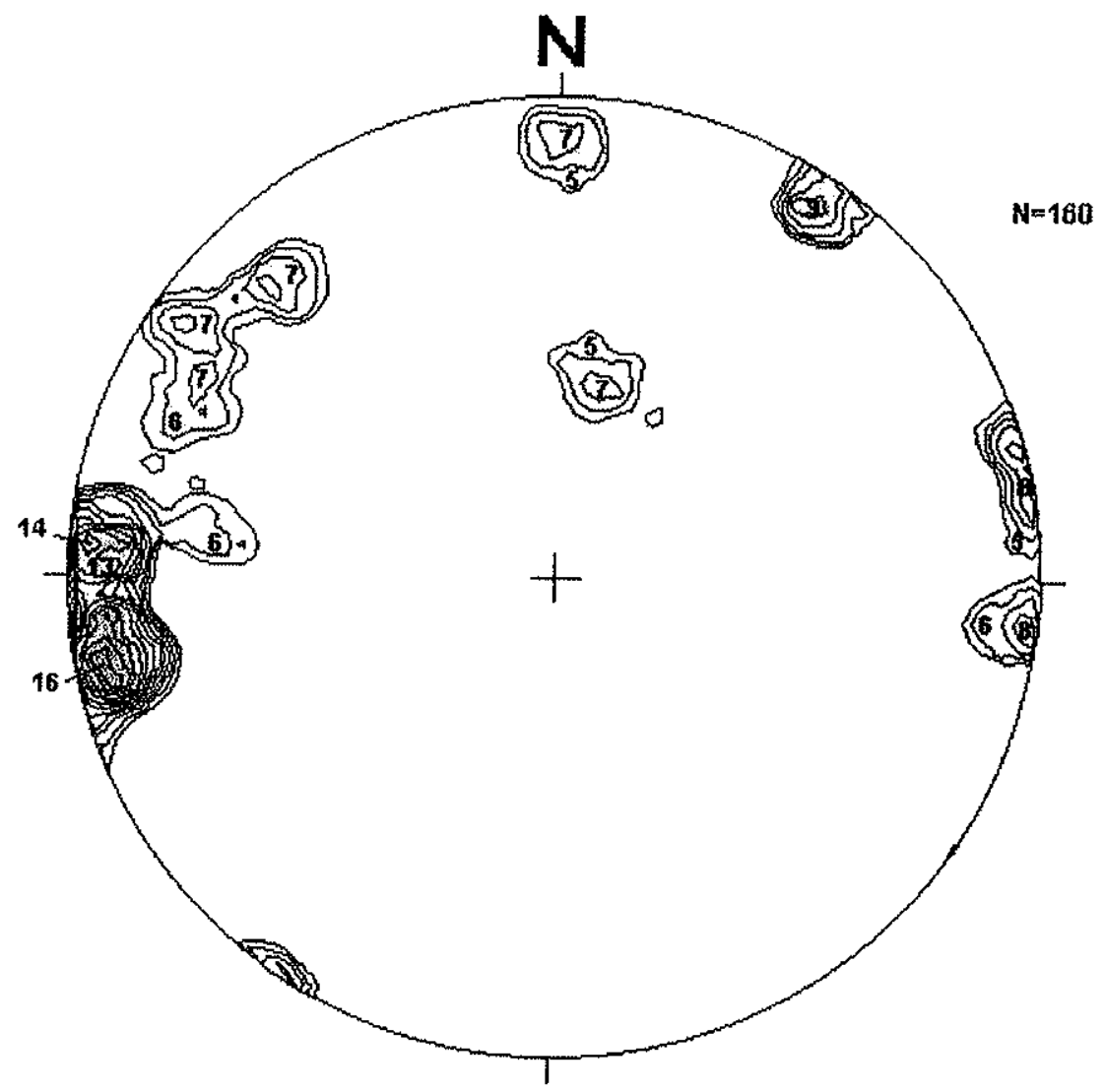

Figura 30 - Diagrama de contorno de densidade de polos dos planos de fraturas do granitognaisse.

Valores das linhas de isodensidades

\begin{tabular}{|c|c|}
\hline Linhas & $\%$ \\
\hline 3 & 4.62 \\
\hline 4 & 6.15 \\
\hline 5 & 7.69 \\
\hline 6 & 9.23 \\
\hline 7 & 10.77 \\
\hline
\end{tabular}

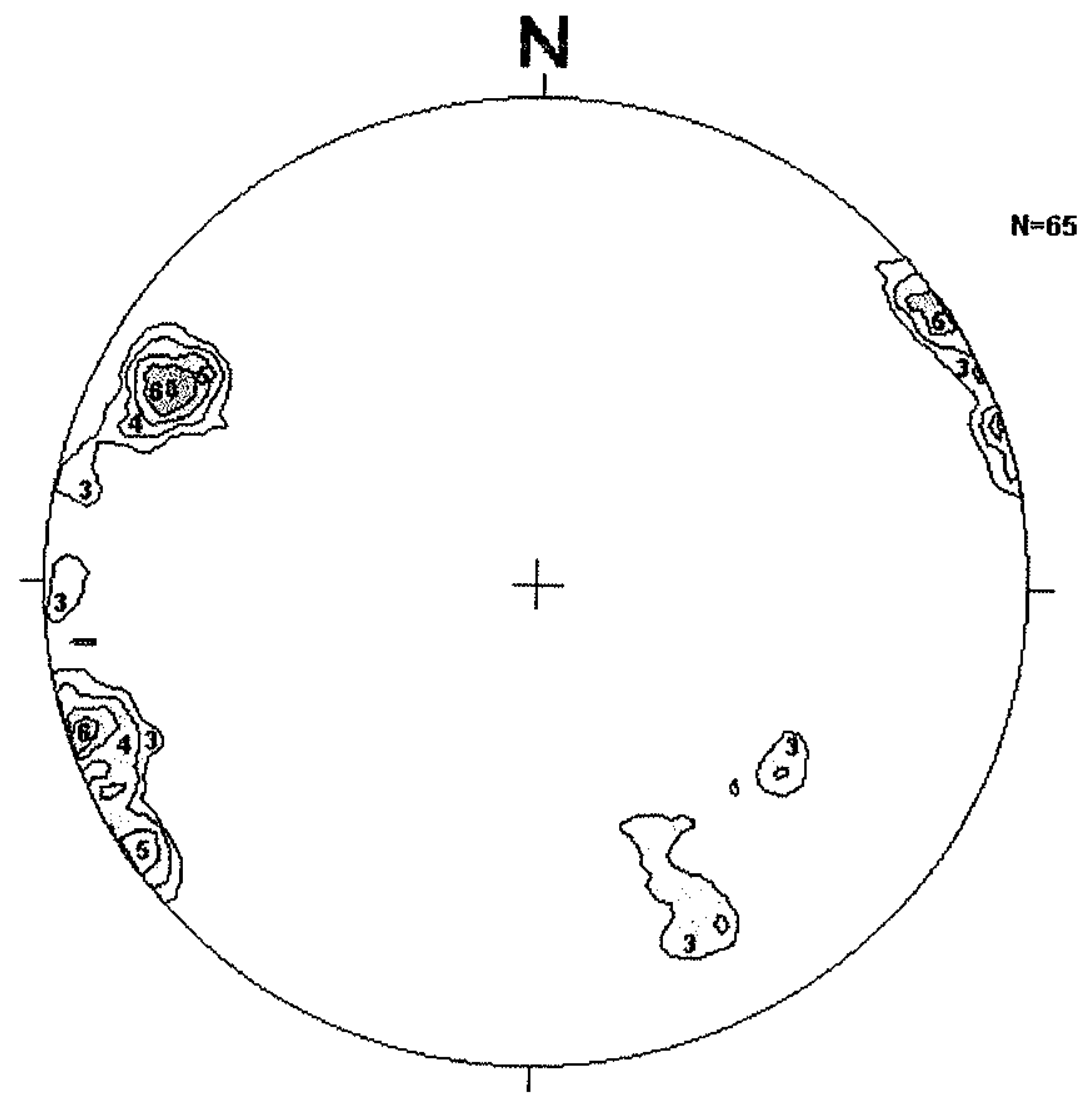

Figura 31- Diagrama de contorno de densidade de polos dos planos de fraturas dos filitos e xistos. 
Granito-gnaisse

(1) N12W/83NE

(2) N03E/85SE

(3) N56W/82SW

(4) $N 16 W / 87 \mathrm{SW}$
Filitos e xistos

(1) N27E/73SE

(2) N19W/86NE

(3) N35W/86NE

(4) N36W/87SW

Como se pode observar, as direções das principais famílias de fraturas, nos dois grupos de rocha, não guardam nenhuma semelhança com a direção da xistosidade.

Comparando estas principais famílias de fratura com os lineamentos fotointerpretados (Figura 25) verifica-se a existência de certa correspondência entre suas direções e os maiores traços individuais de lineamentos, ao contrário do que se observou entre estes últimos e as principais famílias em termos de número de lineamentos (Figura 26 b).

Contudo, ao se confrontar os dados de campo (Figuras 28 a 31) com os resultados estatisticos obtidos de fotografia aérea (Figura 26 a e b), verifica-se a ausência de correspondencia entre as principais famílias de fraturas, em ambos os litotipos, o que pode ser explicado pela diferença entre as populações de dados analisados, conforme indicados na Tabela 2, e devido à fotointerpretação ter abrangido uma área maior que a área de estudo.

Tabela 2 - Comparação entre populações de dados de fraturas obtidas em fotografia aérea e no campo.

\begin{tabular}{|c|c|c|}
\hline Tipo de Rocha & Fotointerpretação & Campo \\
\hline Granito-gnaisse & 280 lineamentos & 160 fraturas \\
\hline Filitos e xistos & 836 lineamentos & 65 fraturas \\
\hline
\end{tabular}




\subsubsection{1 - Análise cinemático-estrutural}

Em trabalhos de prospecção de água subterrânea em aqüiferos fraturados, a identificação das direções principais dos esforços tectônicos vigentes é uma das etapas mais importantes da análise estrutural dos maciços rochosos, que constituem os aqülferos, pois é a partir dessas direções que se reconhece as estruturas favoráveis ao armazenamento de água.

A identificação das direções principais de esforços é realizada através do estudo dos movimentos relativos dos planos de falha, a partir dos indicadores cinemáticos tais como: degraus formados por minerais, ressaltos, fendas de tração, estrias de atrito ou de cisalhamento, alternância de faces polidas e rugosas.

Durante a fase de mapeamento, especialmente na região das pedreiras (porção norte da área), foram medidas 24 (vinte e quatro) falhas de caráter predominantemente transcorrente (Anexo 1).

Os indicadores cinemáticos utilizados nesta pesquisa, para a caracterização dos movimentos, foram basicamente de duas naturezas: ressaltos e estrias de atrito, conforme ilustrados nas Figuras 32 a 35.

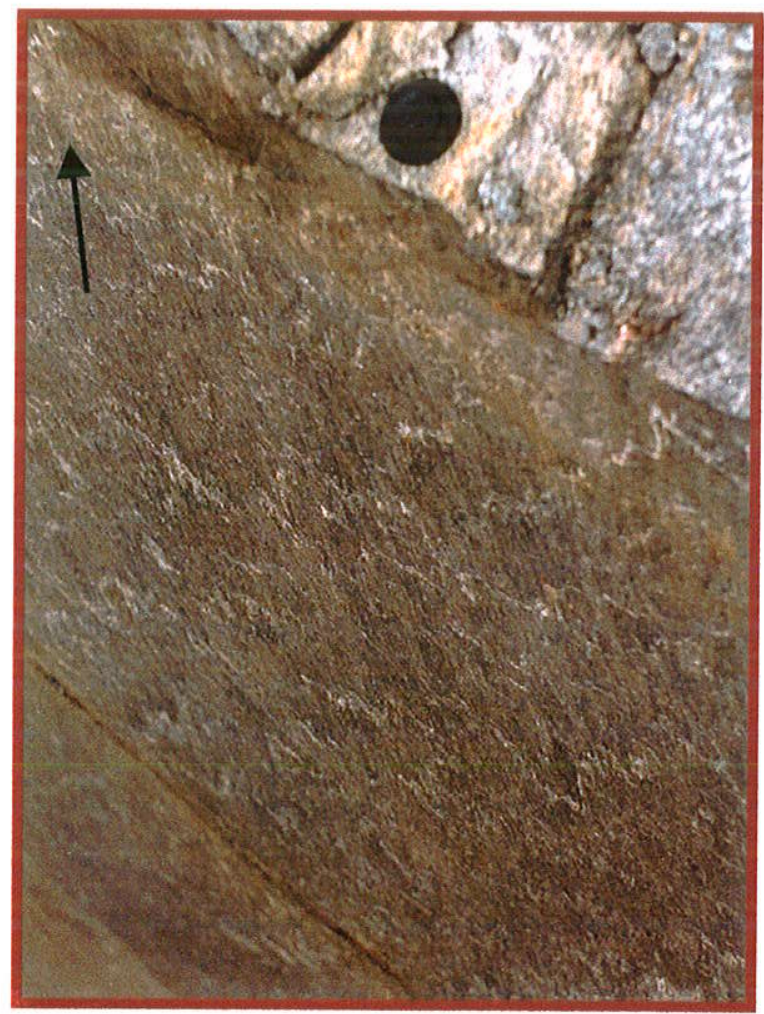

Figura 32 - Ressaltos em espelho de falha, em granito-gnaisse, indicando movimento dextral. A seta indica o sentido do movimento do bloco de cima (Figura 22 - afloramento 9). 


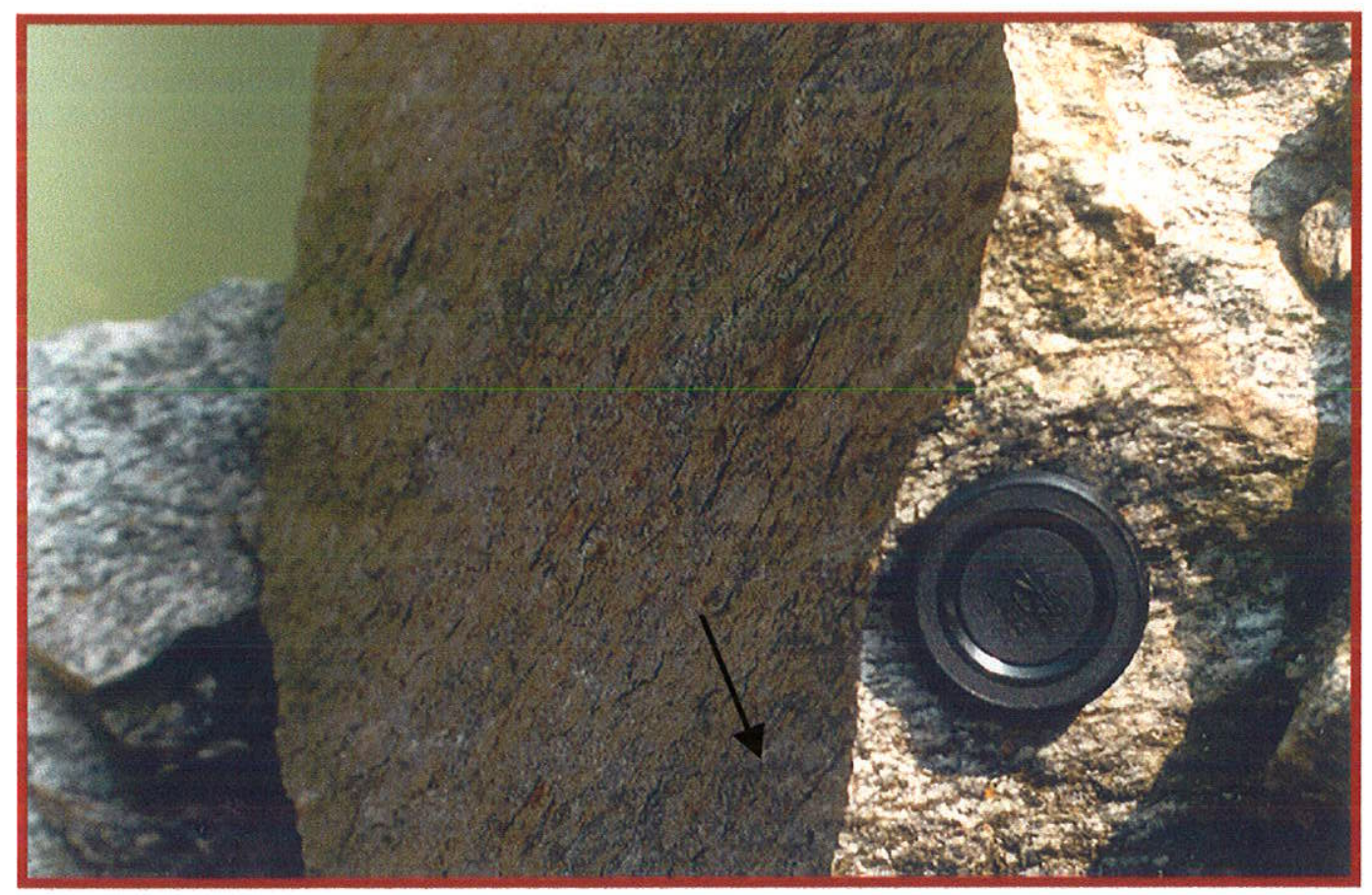

Figura 33 - Ressaltos em espelho de falha, em granito-gnaisse, indicando movimento sinistral. A seta indica o sentido do movimento do bloco de cima (Figura 22 - afloramento 9).

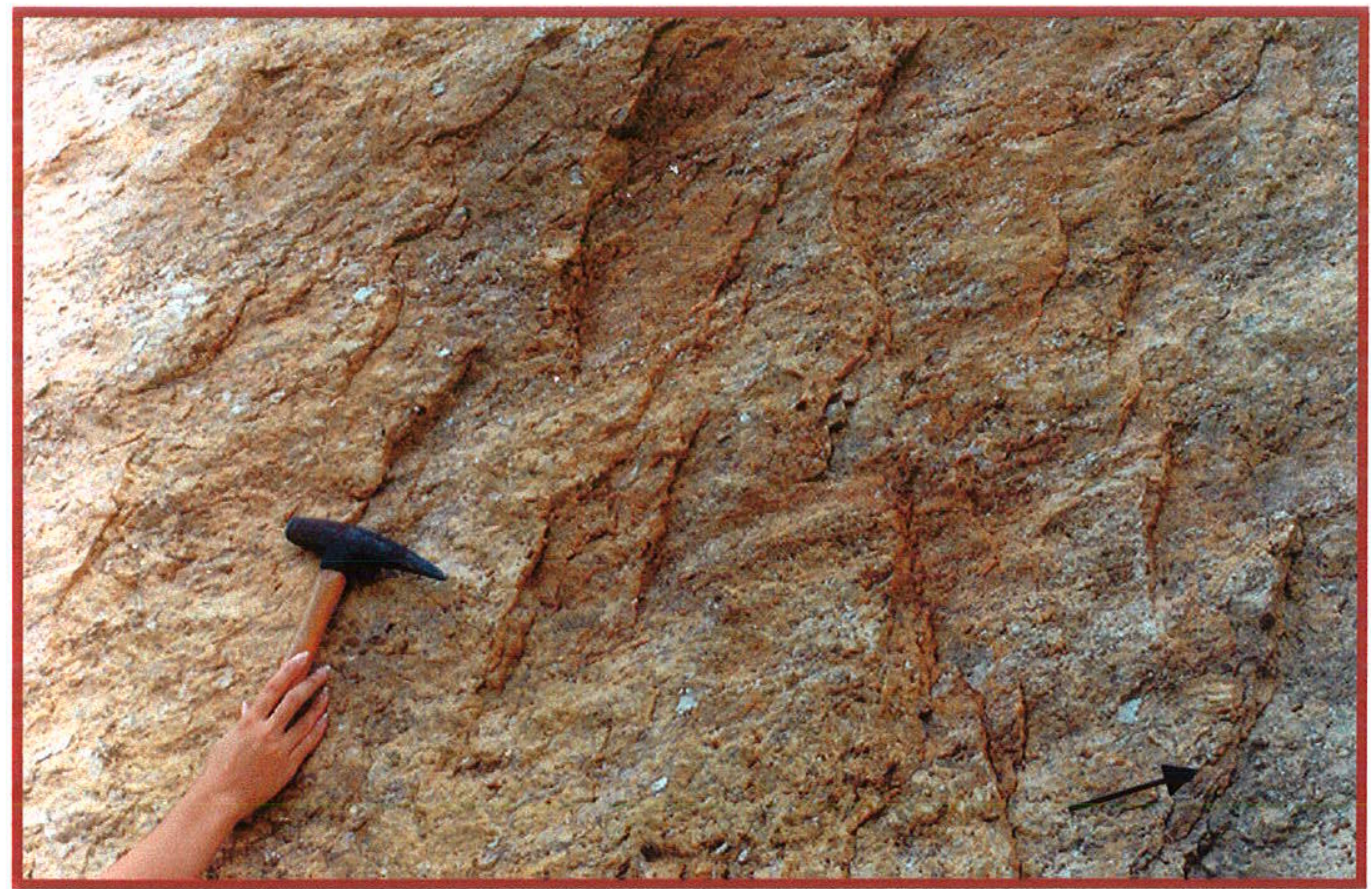

Figura 34 - Ressaltos em plano de fratura, em bolsão pegmatítico, indicando movimento sinistral. A seta indica o sentido do movimento do bloco da frente (Figura 22 - afloramento 14). 


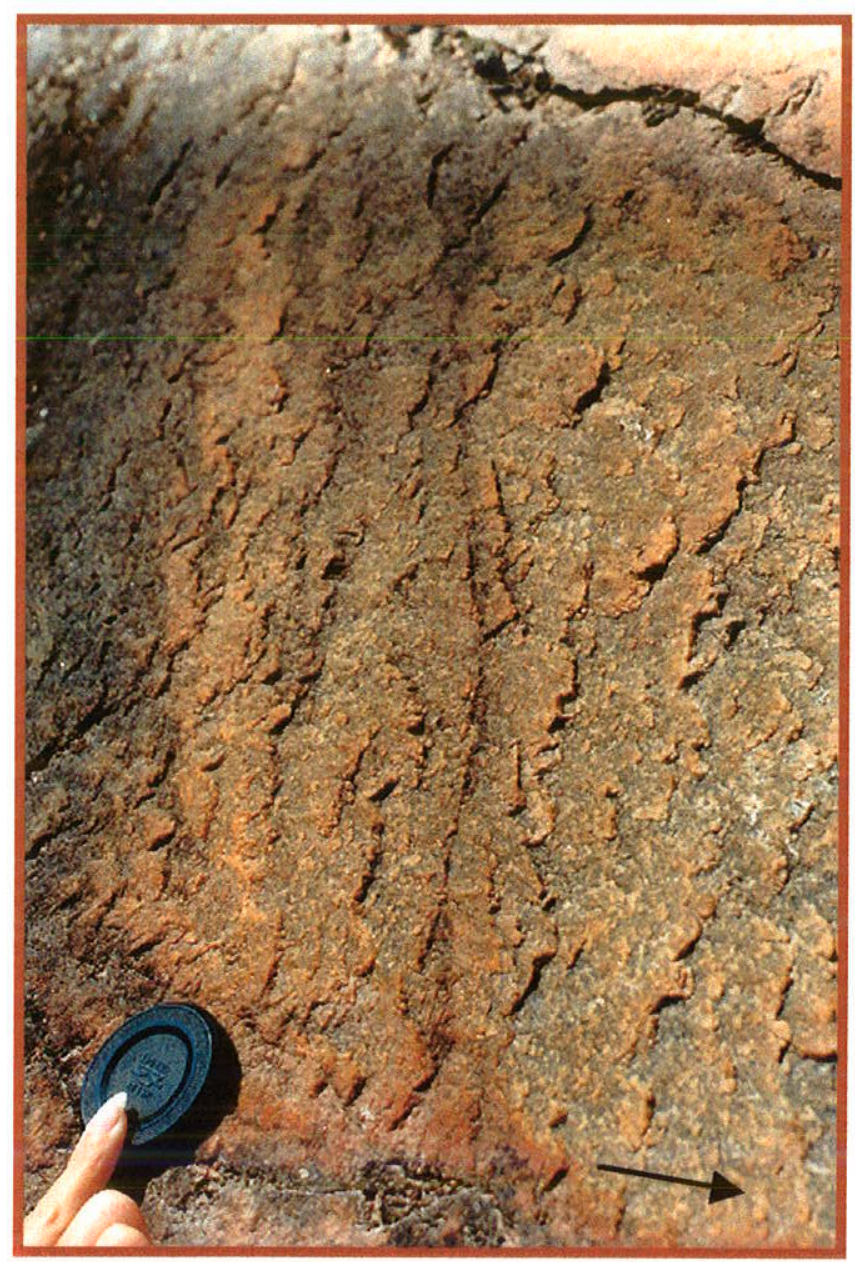

Figura 35 - Ressaltos em plano de fratura, em granito-gnaisse, indicando movimento sinistral. A seta indica o sentido do movimento do bloco da frente (Figura 22 - afloramento 14).

Dentre as 24 (vinte e quatro) falhas, 17 (dezessete) tiveram a direção e o sentido do movimento (dextral ou sinistral) identificados no campo. Essas informações, juntamente com as orientações dos planos de falha e das estrias neles contidas, foram lançadas num diagrama de Schmidt-Lambert (projeção ciclográfica) para a determinação das direções dos esforços principais $\left(\sigma_{1}, \sigma_{2}\right.$ e $\left.\sigma_{3}\right)$. Com isso obteve-se quatro direções distintas para o esforço principal $\sigma_{1}$, apresentados na Tabela 3 .

Dentre estas 4 (quatro) direções, selecionou-se apenas os dois primeiros pares falha/estria para a elaboração dos diagramas dos diedros retos (Método de Angelier \& Mechler - descrito no capítulo 3, item 3.3.1.2), por serem os mais representativos em número de medidas (Figuras 36 e 37), obtendo-se assim as regiões em que se encontra o tensor de esforço máximo $\sigma_{1}$. 


\section{Conjunto de falhas com $\sigma_{1}$ horizontal N-S}
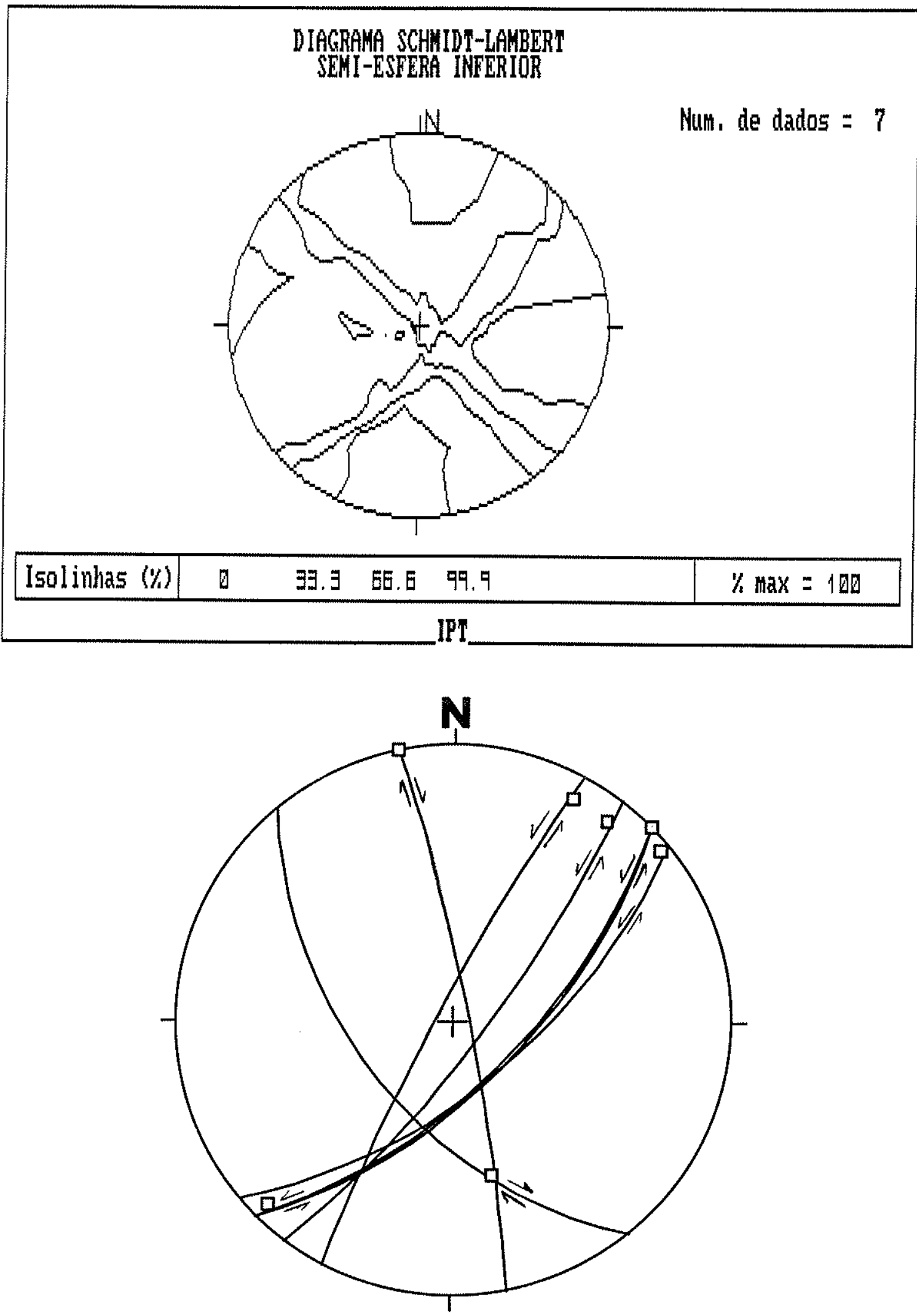

Figura 36 - Análise pelo Método de Angelier das falhas geradas por um campo principal de esforço $\left(\sigma_{1}\right)$ horizontal e N-S. 
Conjunto de falhas com $\sigma_{1}$ horizontal E-W
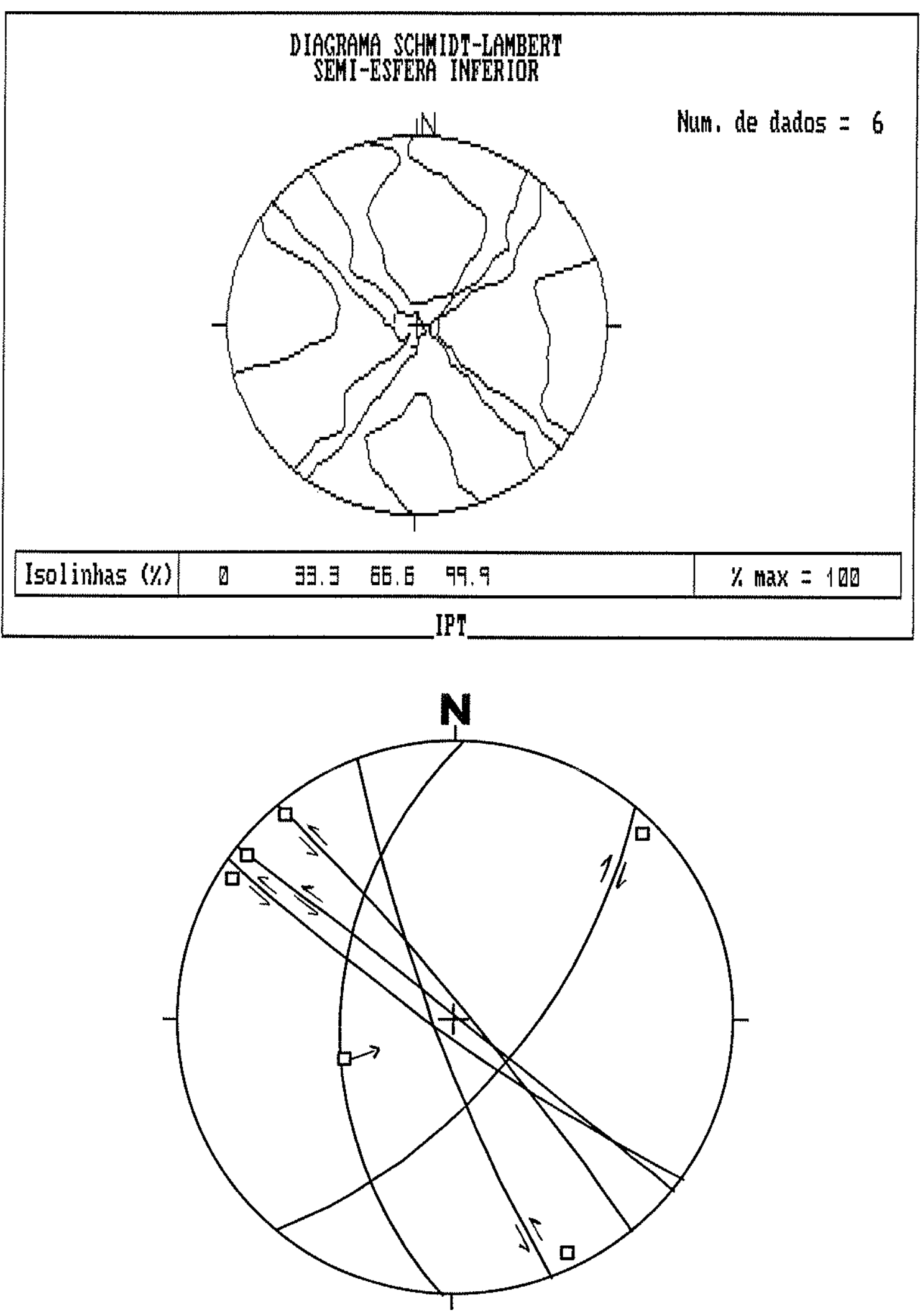

Figura 37 - Análise pelo Método de Angelier das falhas geradas por um campo principal de esforço $\left(\sigma_{1}\right)$ horizontal e E-W. 
Tabela 3 - Direções do esforço principal $\sigma_{1}$ em função do número de estruturas observadas.

\begin{tabular}{|c|c|}
\hline $\begin{array}{c}\text { Direção do esforço } \\
\text { principal } \sigma_{1}\end{array}$ & Pares falha/estria \\
\hline N-S & 7 \\
\hline E-W & 6 \\
\hline NE-SW & 2 \\
\hline NW-SE & 2 \\
\hline
\end{tabular}

Como não foram observadas evidências cronológicas referentes às falhas não é possivel afirmar qual das direções representa a direção do esforço máximo vigente $\left(\sigma_{1}\right)$ Contudo, com base nas conclusões de RICCOMINI (1995) e ASSUMPÇÃO (1998), que consideram um sistema compressivo E-W como o último evento atuante na região, a direção E-W estará sendo considerada neste estudo, como a que hoje condiciona o fluxo de água subterrânea no aqüifero fraturado em estudo.

Sendo assim, ao se posicionar o esforço principal $\sigma_{1}$ na direção E-W sobre o mapa de lineamentos obtido através da fotointerpretação (Figura 25), têm-se uma indicação das prováveis fraturas abertas, na área de estudo, que são as mais favoráveis ao armazenamento de água (Figura 38).

\section{2 - Levantamento do uso e ocupação territorial}

Através de estudo de fotografias aéreas foi elaborado o mapa de uso e ocupação da área (Figura 39), onde IEZZI (1999) reconheceu dez classes distintas, conforme discriminadas a seguir:

- área industrial: ocorrem indústrias e galpões industriais;

- área industrial/comercial: ocorrem indústrias e estabelecimentos comerciais, incluindo uma empresa de ônibus, muito próximas umas das outras;

- área mista: compreende indústrias, estabelecimentos comerciais e residências muito próximas umas das outras; 


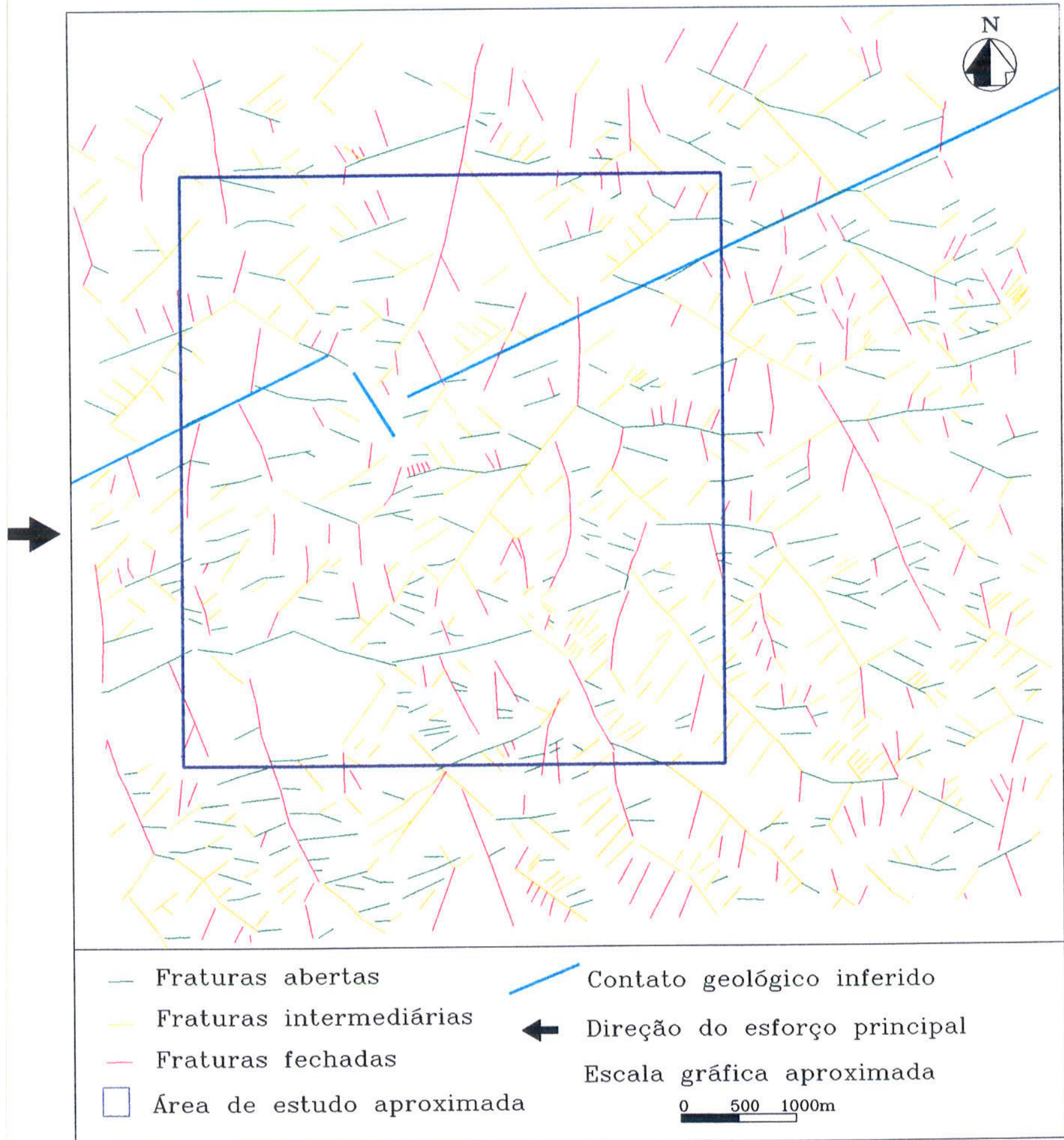

Figura 38 - Mapa de lineamentos com indicação das prováveis fraturas abertas (foto 331, faixa 8C). 


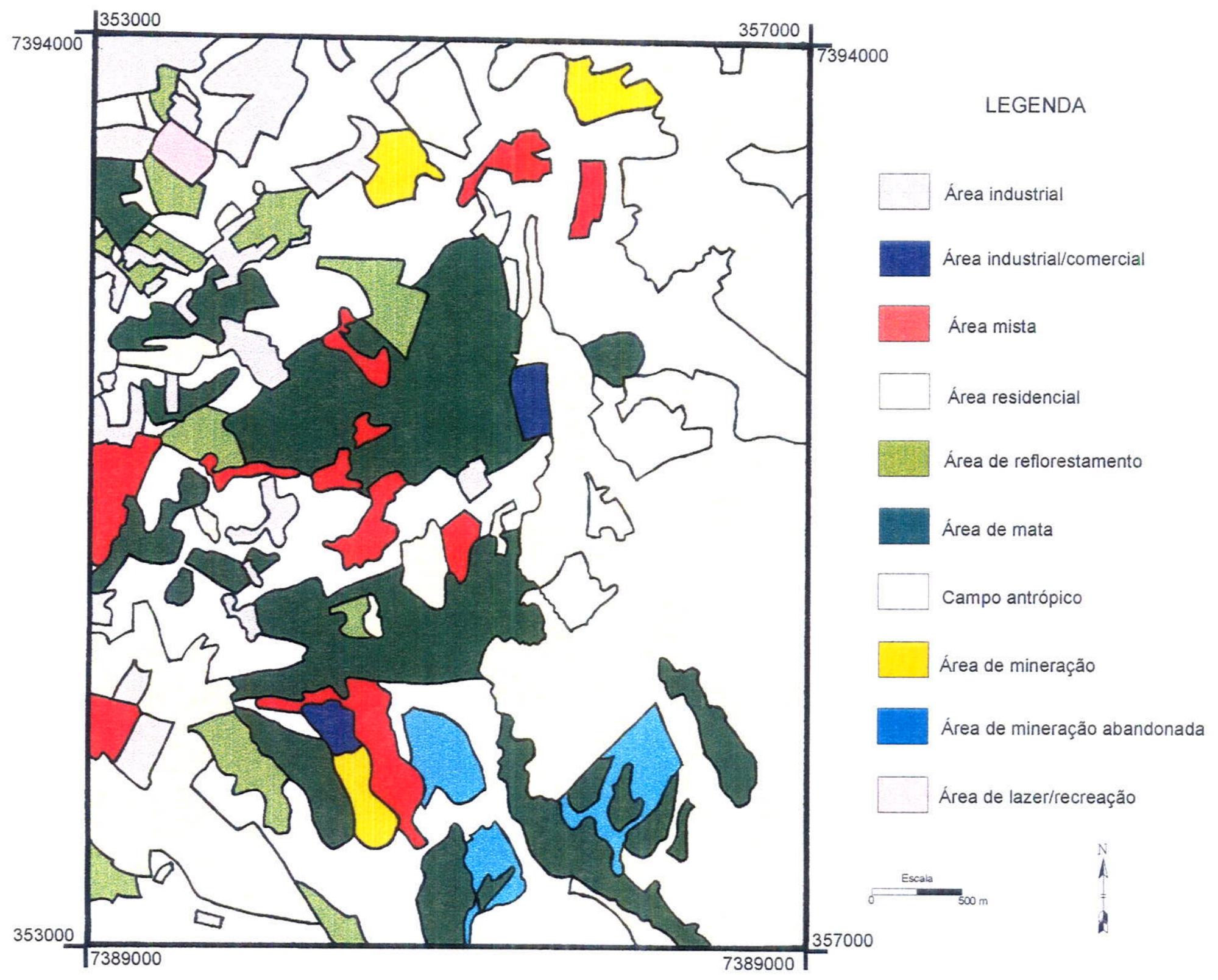

Figura 39 - Mapa de uso e ocupação da área de estudo (lezzi, 1999). 
- área residencial: abrange os conjuntos habitacionais da CDHU e COHAB, localizados na porção leste da área, residências em chácaras e residências próximas às áreas industriais e/ou comerciais;

- área de reflorestamento: inclui pequenas plantações como hortas, cultivo de cítricos, plantio de pinheiros e eucaliptos;

- área de mata: compreende áreas de mata nativa e secundária, cuja vegetação é densa a medianamente densa quando comparada com áreas contíguas.

- campo antrópico: refere-se a áreas com pouca ou nenhuma vegetação e terrenos desocupados;

- área de mineração: corresponde a áreas de explotação mineral ativas;

- área de mineração abandonada: corresponde a áreas de exploração mineral abandonadas ou temporariamente paralisadas;

- área de lazer ou recreação: corresponde a um clube recreativo.

Em virtude do mapa de uso e ocupação ter sido elaborado com fotografias aéreas do ano de 1996, fez-se necessário um levantamento de campo para atualizar e complementar as informações disponiveis. Nesta fase foram cadastradas quase todas as empresas e estabelecimentos instalados na área, resultando no cadastramento de 126 (cento e vinte e seis) pontos plotados em mapa (Figura 40), que abrangem os seguintes tipos: estabelecimentos industriais (indústrias metalúrgicas, de equipamentos industriais, alimenticias, de produtos químicos, etc), comerciais (fábricas de blocos de concreto, recauchutadoras de pneus, marmoraria, retífica de motores, postos de serviços, etc), educacionais (centros pró-excepcionais, orfanato e colégio), recreativos (clubes), rurais (sítios, chácaras e granjas), residenciais (casas e barracos em favela) e viações de ônibus.

Especificamente na área Fazenda do Carmo, verificoumse que alguns trechos (principalmente às margens da Estrada do Iguatemi) são ocupados por invasões, algumas delas muito antigas. Estas ocupações irregulares diferenciam-se pela existência de algum tipo de atividade comercial associada (depósito de ferro-velho, papelão, desmanche de veículos, fábrica de blocos, etc). 


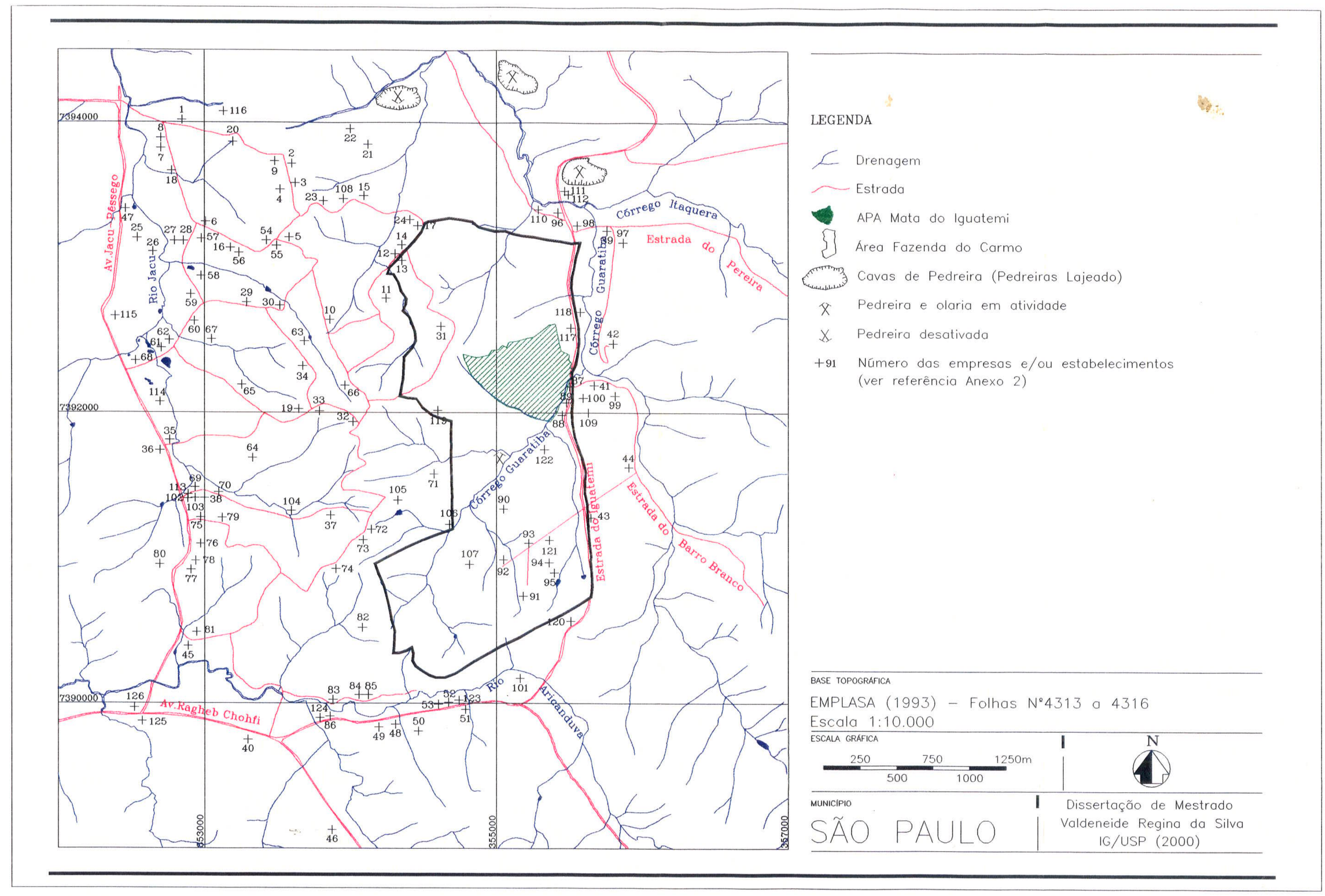

Figura 40 - Mapa de localização das empresas e/ou estabelecimentos visitados. 
Nas visitas de campo também foram levantadas informações relacionadas ao abastecimento de água e ao saneamento básico. Neste sentido, verificou-se que a rede de água da SABESP atende apenas uma parcela da população, enquanto a maioria é obrigada a se utilizar da água subterrânea através de poços. O mesmo acontece com o saneamento básico que é feito parcialmente pela rede de esgoto pública e parcialmente por meio de fossas sépticas ou negras. Contudo, o que se verifica ainda em alguns locais é o lançamento de esgoto "in natura", que escorre pelas ruas, como observado próximo ao limite norte da Fazenda do Carmo.

O levantamento do uso e ocupação também visou o cadastramento de fontes potenciais de contaminação da água subterrânea, que se iniciou com a pesquisa de dados na literatura. Conforme citado no capítulo 4 (item 4.2), dentre os dados levantados destacase o levantamento ambiental realizado pela PREFEITURA DO MUNICÍPIO DE SÃO PAULO - SECRETARIA MUNICIPAL DO VERDE E DO MEIO AMBIENTE (1996), na área denominada "Passagem Funda" (situada no extremo leste da área Fazenda do Carmo), que relata atividades potencialmente poluidoras e a disposição inadequada de resíduos sólidos (Tabela 4). Dentre estas atividades, a que merece maior destaque é, sem dúvida, a atividade informal de lavagem e recuperação de tambores $e$ bombonas, por causarem impactos no meio físico, biológico e antrópico. Segundo o relatório da prefeitura, os tambores e bombonas metálicos (200 litros), contendo resíduos (tintas, óleos, solventes e outros), são transportados do bairro de Santo Amaro para as recuperadoras existentes na área de estudo, onde são lavados e desamassados para posterior comercialização. Quando os tambores chegam nas recuperadoras, os residuos neles contidos são descartados em poços (Tabela 4), córregos e nos solos. A lavagem é mecânica e usa solventes à base de xileno e tolueno, que já haviam sido utilizados em outros processos industriais. Em seguida, são desamassados através de injeção de ar sob pressão e comercializados para empresas no interior do estado, que Ihes dão acabamento final: pintura externa, fechamento, vedação e colocação de bocal e tampa.

Numa das visitas realizadas na área verificou-se que aquelas recuperadoras situadas dentro do perimetro da área Fazenda do Carmo já não mais realizavam as atividades com os tambores e bombonas, contudo num dos pontos localizados em área de várzea junto ao córrego Guaratiba, cujas instalações são periodicamente inundadas (Figura 41), foi observada a reciclagem de latas de tinta menores (18 litros). Neste mesmo local, também observou-se a disposição de tambores, areia de fundição e substâncias químicas (transportadas em sacos plásticos e/ou junto com os tambores) (Figura 42). Apesar da paralisação das atividades naquelas recuperadoras, seus efeitos danosos sobre o meio 
Tabela 4 - Atividades industriais na área "Passagem Funda" e suas irregularidades.Compilado a partir de PREFEITURA DO MUNICÍPIO DE SÄO PAULO - SECRETARIA MUNICIPAL DO VERDE E DO MEIO AMBIENTE (1996)

\begin{tabular}{|c|c|c|c|c|c|c|}
\hline & & & & C SAUPAULC & & \\
\hline Hidrolete Produlos Termoplásticos & R. Săo Simăo, :a & Mauricio Pinheirio Rodirigues & 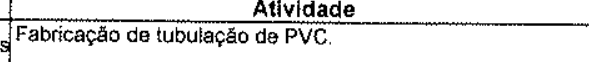 & Irregularldades & Destinąăáo dos Residuos & observaçăio \\
\hline Fábrica de Plásticos Săo Sebastiăo & R. Santa Teresa & Wagner Alves Gramarin & $\begin{array}{l}\text { Recicicagem de polietitieno, comercicio de papeläo, plásticos } \mathrm{e} \\
\text { arame. }\end{array}$ & 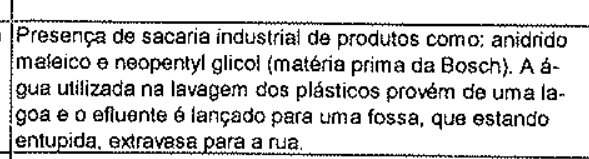 & & 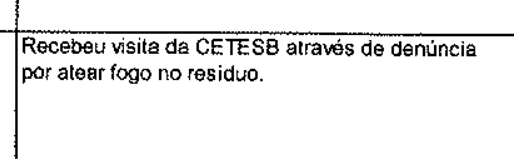 \\
\hline Ind, e Com. Recuperadora de Aluminio Appol Lda & R. do Campo & Clíudio Moriconi & 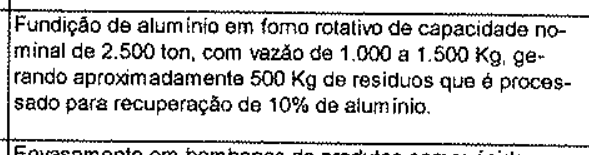 & & 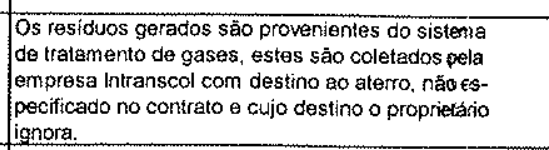 & 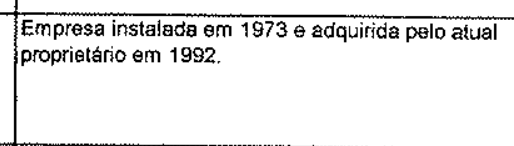 \\
\hline Empresa Betânia - Com. de Produlos Quimicos & Estrada do kguatemi,5836 & & 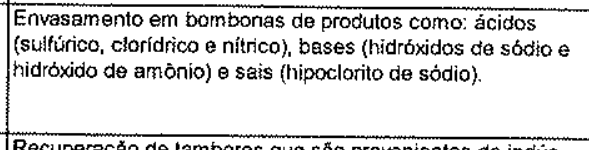 & 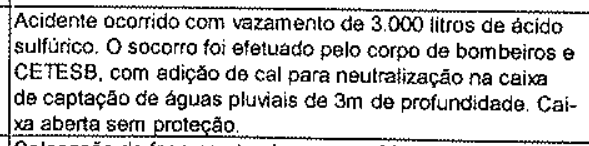 & & \\
\hline Recicladora de Tambores e Bombonas & R. do Campo & Sidney de Oliveira & 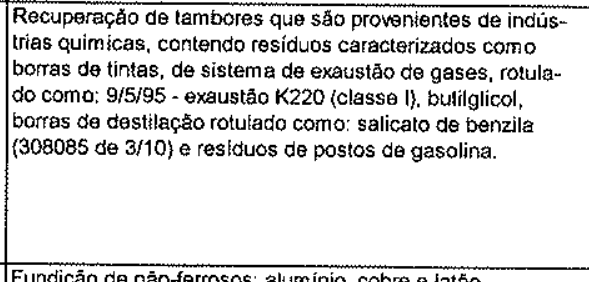 & 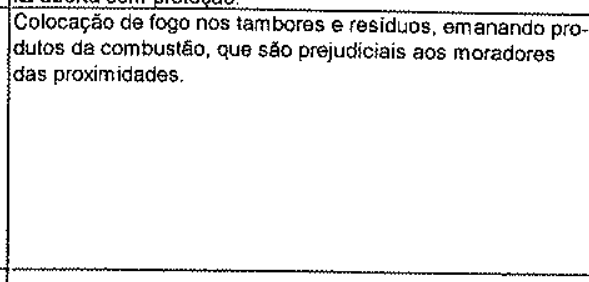 & 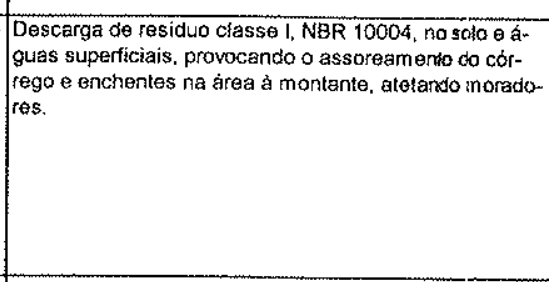 & 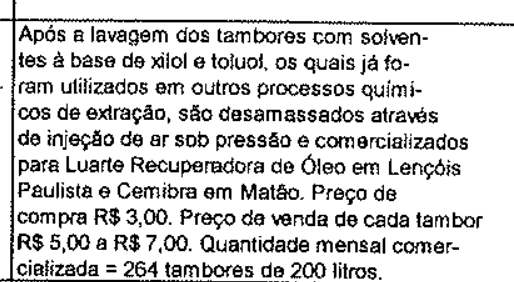 \\
\hline Recauchutadora de Pnous imperial & R.Tineciro Kibaci, 1211 & Rafffelli Cafftetani & 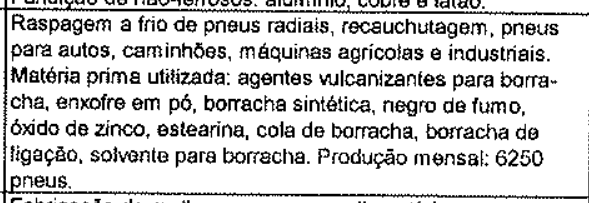 & 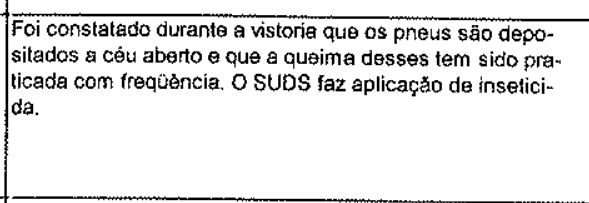 & 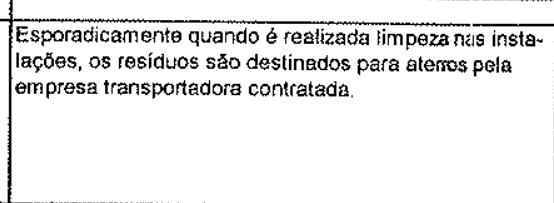 & 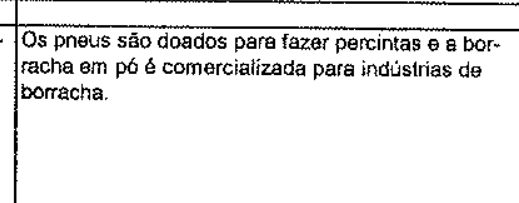 \\
\hline Amiriana Industrial Impor. \& Exxot. de Alimentos Lida & R. Tineciro Icibaci, 2337 & & Fabricą̧ăo de moithos $\theta$ conservas alimenticias. & & 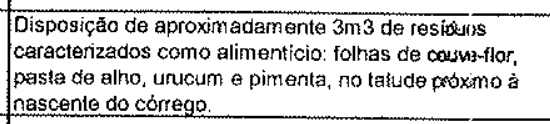 & \\
\hline Metaluirgica MF Ind. e Com. Loda. & Av. Souza Ramos, 437 & Antônio Mian & 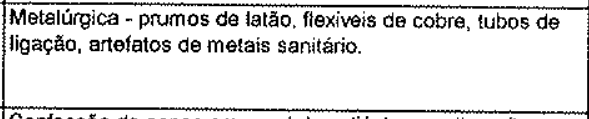 & 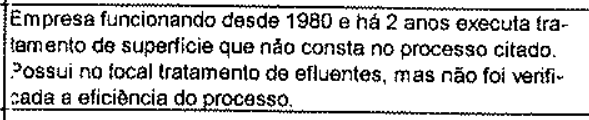 & & \\
\hline 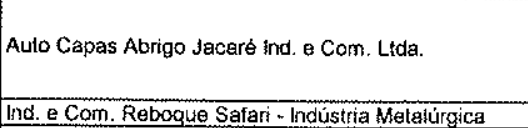 & R.dos Cunha, 60-A & Luiz Clarindo da Silva & 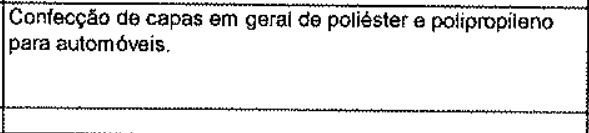 & 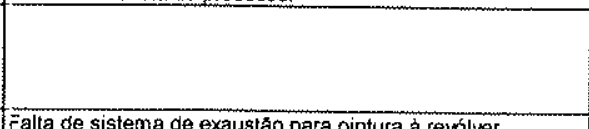 & & 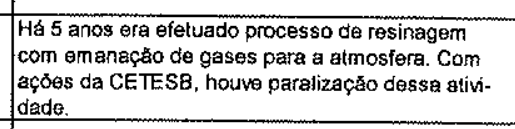 \\
\hline Carbrink Com. e ind, de Cerimboss e Brinquedos & Av. Souza Remos, 25 & Walter Cardos Miranda & & 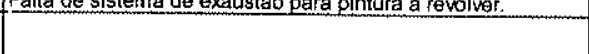 & & Năo foi fetita vistoria na unidade de proceasso. \\
\hline Ranchoneto do Gaúcho & Estrada do huatemi, 1020 & Amaldo de Souza & 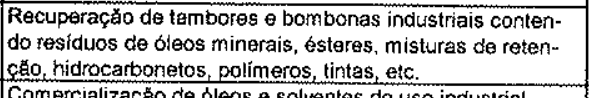 & 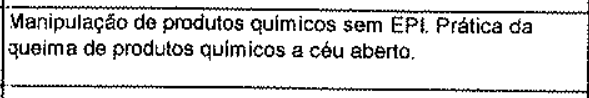 & Descarte de residuos classe ino solo e córegeso. & 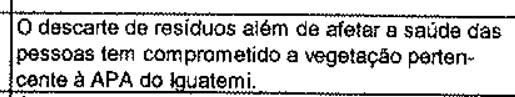 \\
\hline Recuperaçąa da Solventes e Óleos & R.dos cunna & sonew & & & Descarte de residuos classe I dentro do poço rasa. & 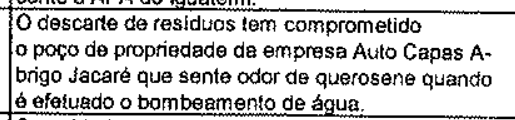 \\
\hline Recauchutadora de Pneus Dinâmica & Estrada do giatemi, 600 & Manoel Flaurentino Afves & Recauchutagem de pnous para ònibus e caminhöes. & 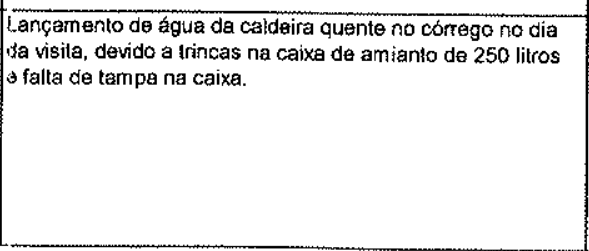 & 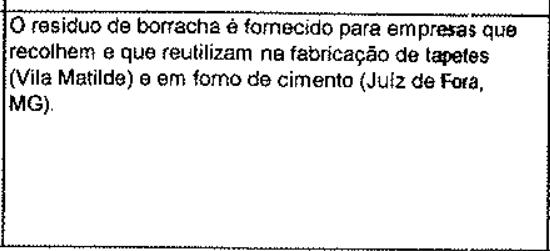 & 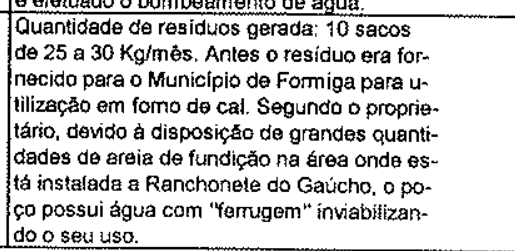 \\
\hline
\end{tabular}




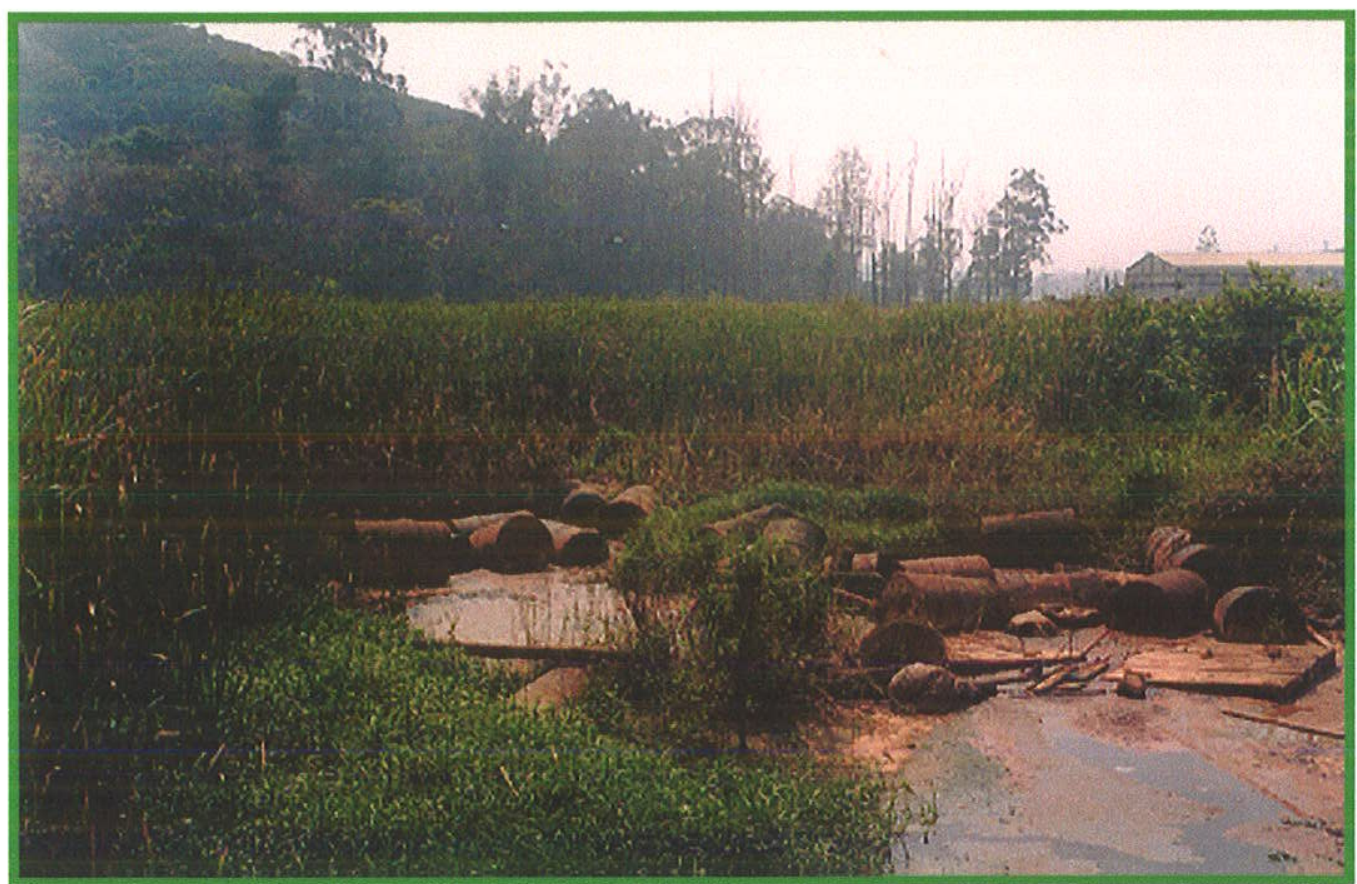

Figura 41 - Local de lavagem e recuperação de tambores localizado em área de várzea, mostrando pontos de alagamento.

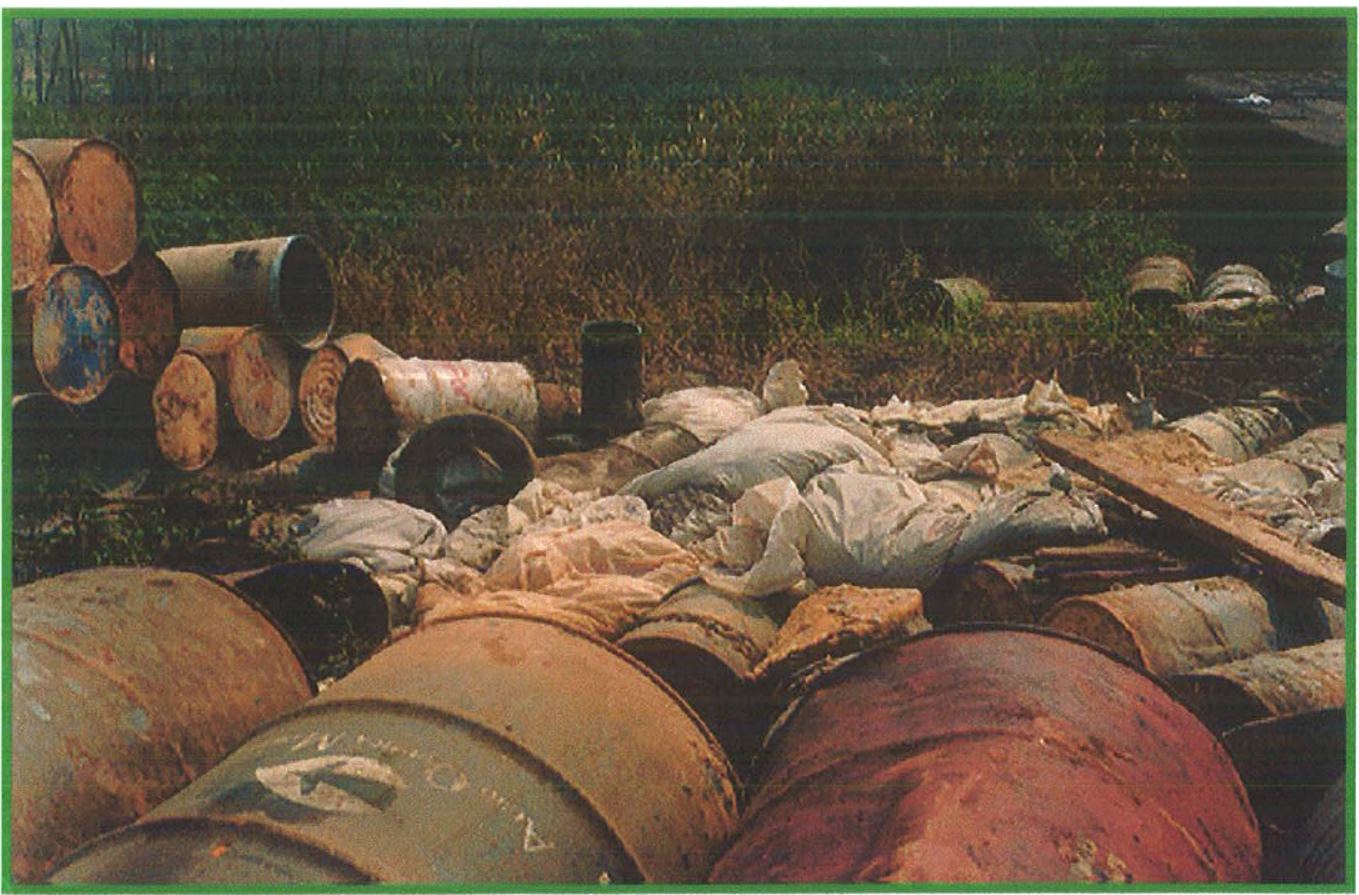

Figura 42 - Armazenamento irregular de sacos plásticos, contendo areia de fundição e produtos químicos, em depósito de tambores e bombonas. 
biológico são nitidamente observados como, por exemplo, sobre a vegetação das bordas da APA Mata do Iguatemi que encontra-se totalmente ressecada (Figura 43).

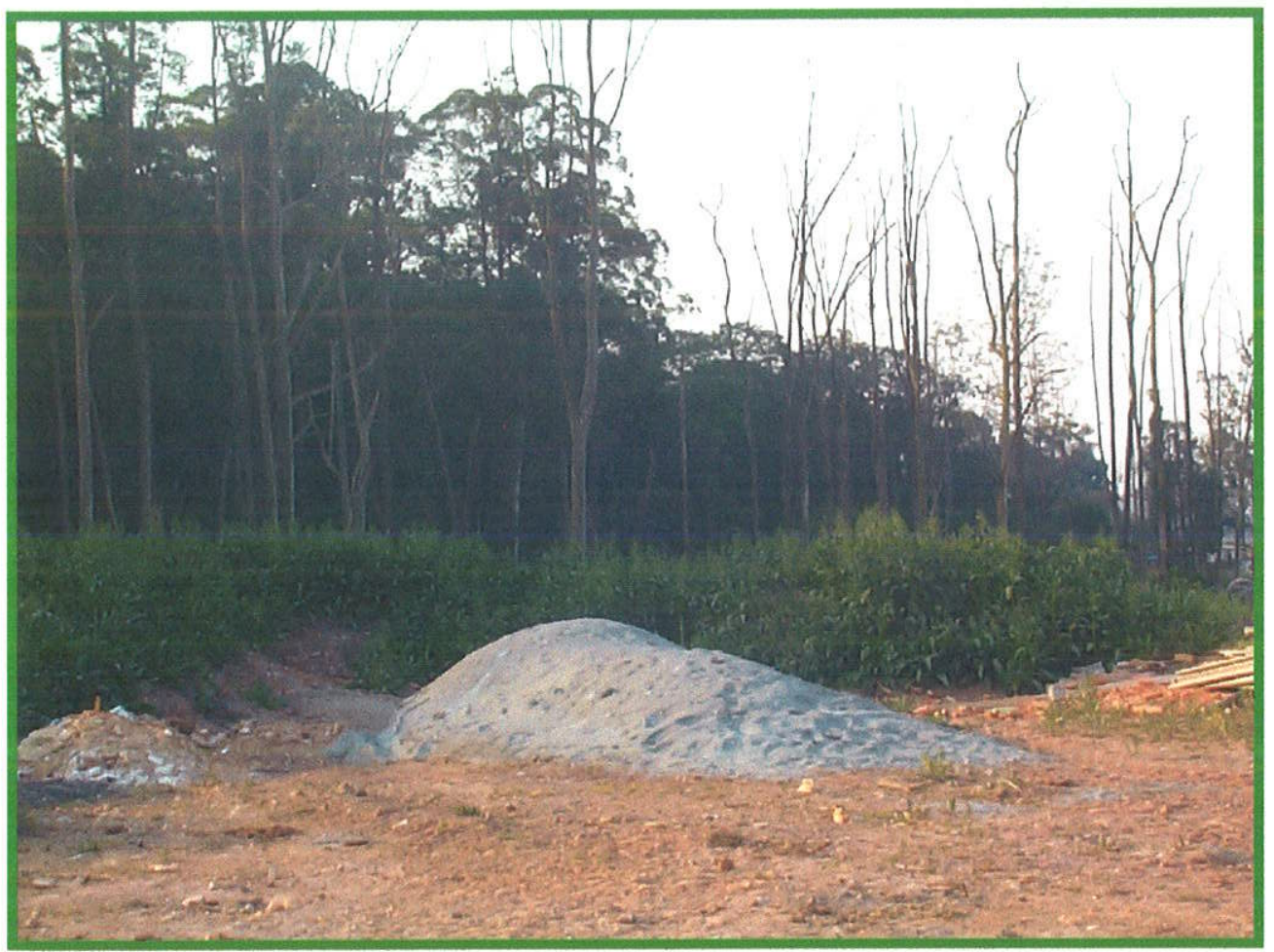

Figura 43 - Borda da APA Mata do Iguatemi mostrando o ressecamento da vegetação devido a atividades antrópicas desenvolvidas em terreno adjacente onde se realizava a atividade de lavagem e recuperação de tambores (ponto 89 Ranchonete do Gaúcho).

Quanto aos pontos de disposição inadequada de resíduos sólidos, são 4 (quatro) os registrados pela prefeitura (Figura 44):

- Ponto A: entulho e/ou solo da obra de construção de galeria de águas pluviais;

- Ponto B: resíduo de limpeza de bueiros;

- Ponto C: depósito de sucatas plásticas (algumas embalagens acondicionava produtos químicos como sorbitol e peróxido orgânico);

- Ponto D: resíduos industriais e domiciliares.

Entretanto, durante os trabalhos de campo realizados na atual pesquisa, notou-se que a disposição de resíduos sólidos já não mais se realiza nos mesmos locais descritos no 


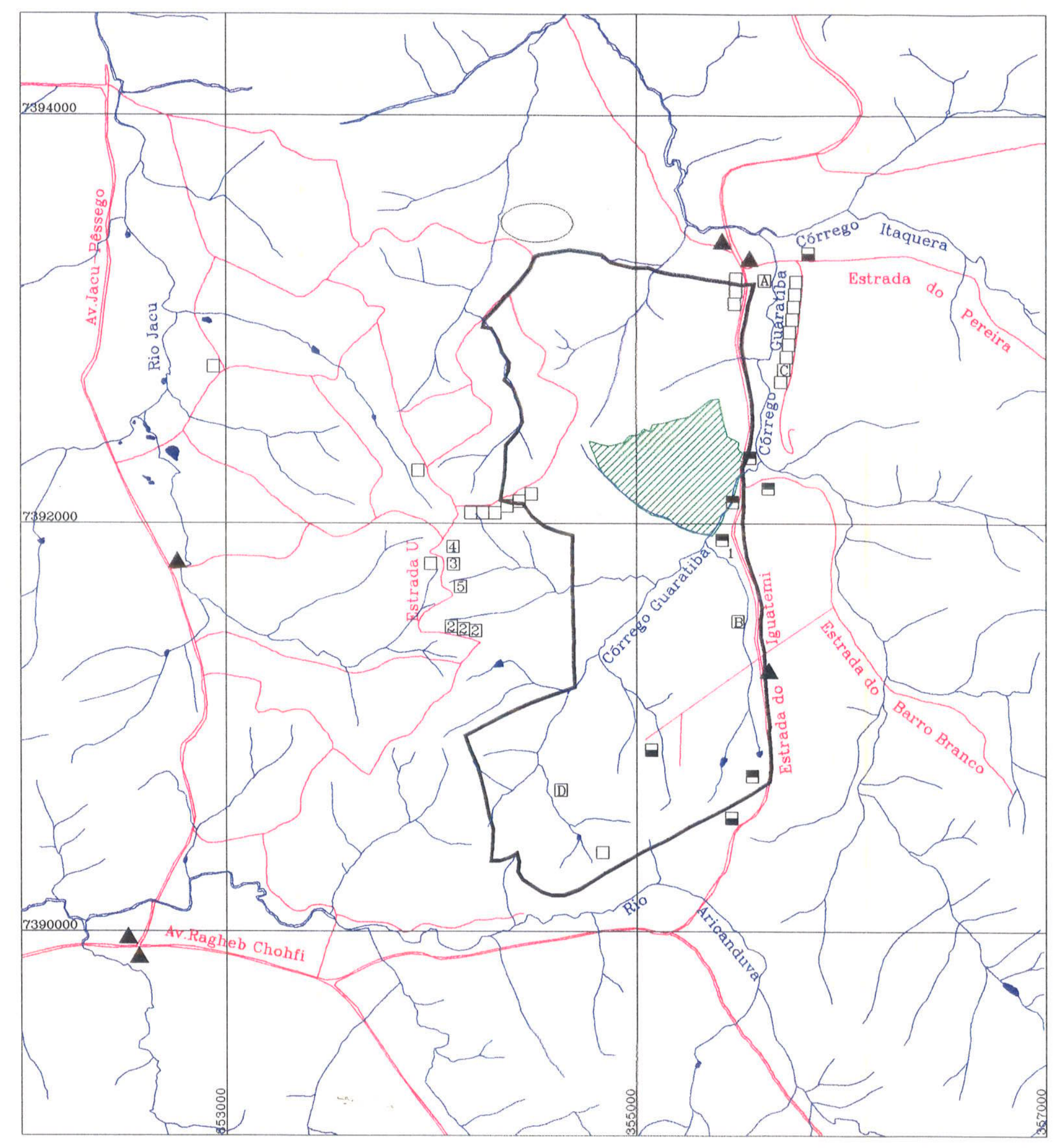

LEGENDA

ᄃ Drenagem

$\sim$ Estrada

- APA Mata do Iguatemi

§Área Fazenda do Carmo

[ Resíduos Sólidos (PREFEITURA do MUNICIPIO DE SÄO PAULO, 1996)

- Lavagem de Tambores (PREFEITURA DO MUNICIPIO DE SAO PAULO, 1996)

$\square$ Resíduos Sólidos (dados de campo)

[2] Pontos com Fotografia

- Lavagem de Tambores (dados de campo)

Postos de Serviços

$\bigcirc$ Cemitério

BASE TOPOGRAFICA

EMPLASA (1993) - Folhas N²4313 a 4316

Escala 1:10.000

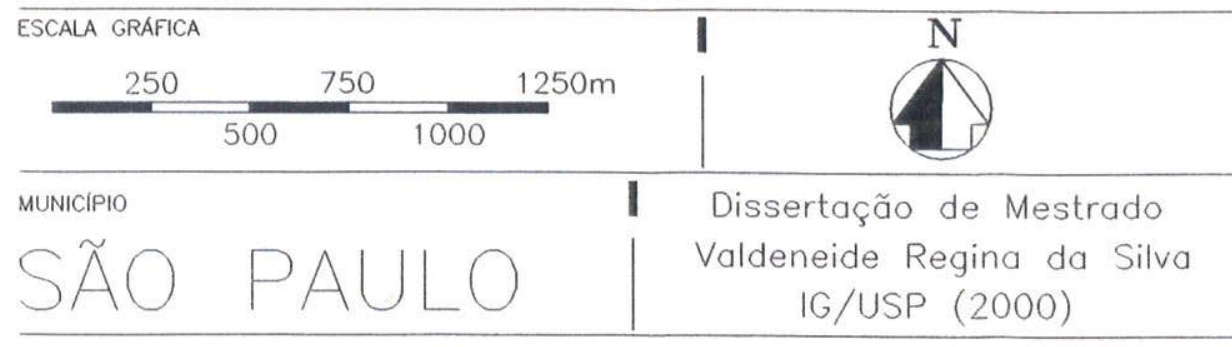

Figura 44 - Mapa de localização de fontes potenciais de contaminação das águas subterrâneas 
relatório da prefeitura, com exceção do ponto $\mathrm{C}$, que até se ampliou numa faixa ao longo da margem do Córrego Guaratiba (Figura 44). Além disso foram identificados novos pontos de descarga de resíduos sólidos, sobretudo ao longo das margens das estradas de terra localizadas em pontos altos da topografia (porção central da área), onde existe pouca movimentação de pessoas e veículos na área (Figura 44). Segundo informação de moradores locais, alguns caminhões que depositam estes resíduos são de propriedade da prefeitura do Município de São Paulo.

Os residuos observados nestes pontos são de naturezas diversas, tais como:

- entulho (madeira, terra, concreto, tijolo, gesso, pedras e serragem);

- pneus e câmaras de tratores e caminhões parcialmente queimados (Figuras $45 \mathrm{e}$ $46)$;

- material plástico (sacos, fitas e potes) parcialmente queimado (Figura 46);

- vidros e garrafas de vidro;

- lã de vidro parcialmente queimada (Figura 47);

- tonéis e latões amassados;

- isopor;

- forração (carpete);

- sofá velho;

- meias novas vindas da fábrica (Figura 48);

- calçados velhos;

- troncos de árvores;

- ovos de galinha;

- animais em decomposição;

- carro "depenado" e queimado.

Um aspecto a ser destacado é que há uma grande reciclagem desses depósitos, ou seja, com a mesma velocidade que os residuos são descartados nestes pontos são transportados para outros locais, o que em parte dificulta a caracterização das fontes potenciais de contaminação da água subterrânea na área.

Além das atividades relatadas na área como fontes potenciais de contaminação da água subterrânea (lavagem de tambores contendo residuos de tintas e solventes e 


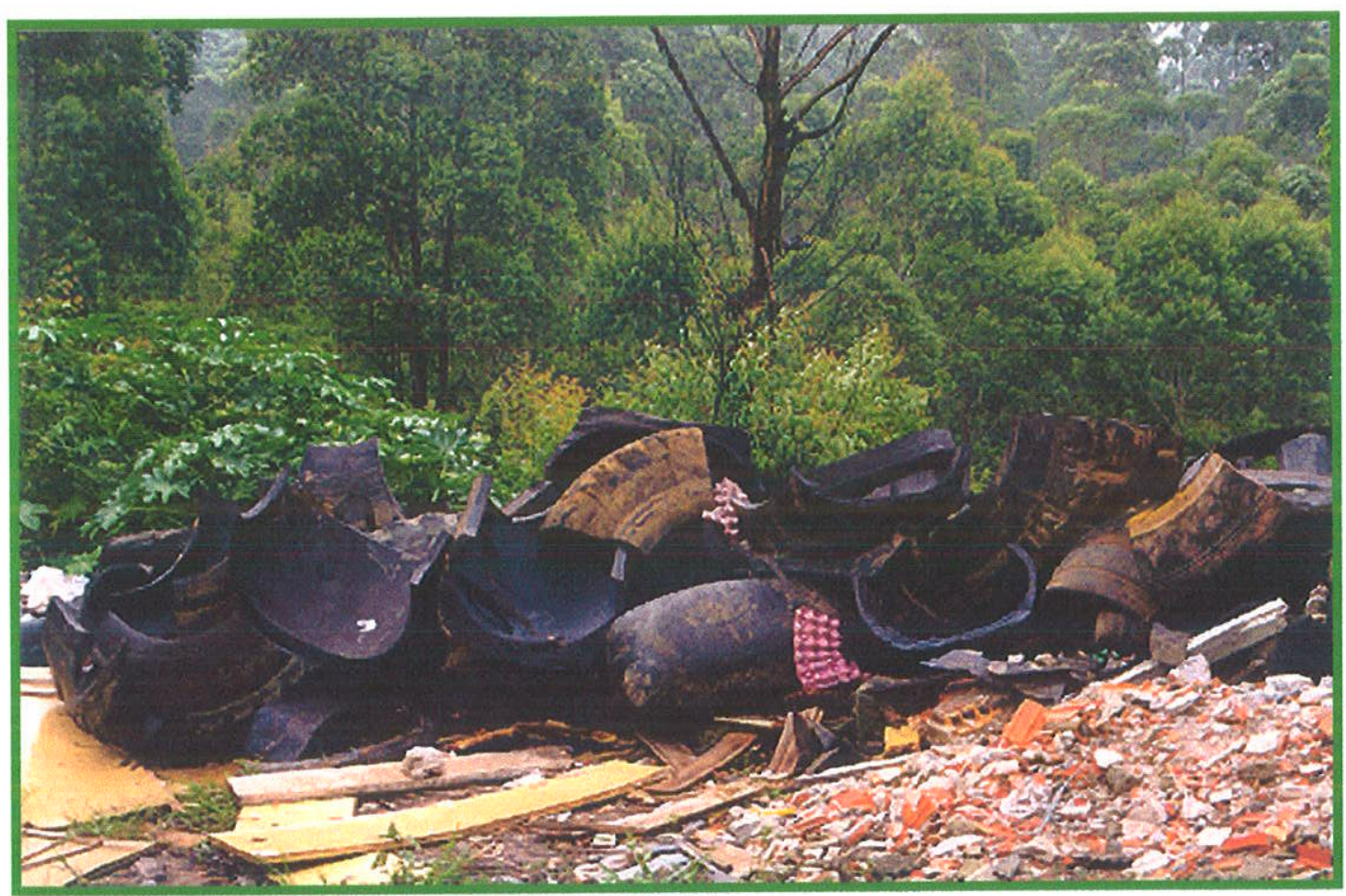

Figura 45 - Câmaras de tratores e de caminhões dispostos irregularmente na margem da estrada U. (Figura 44 - ponto 2)

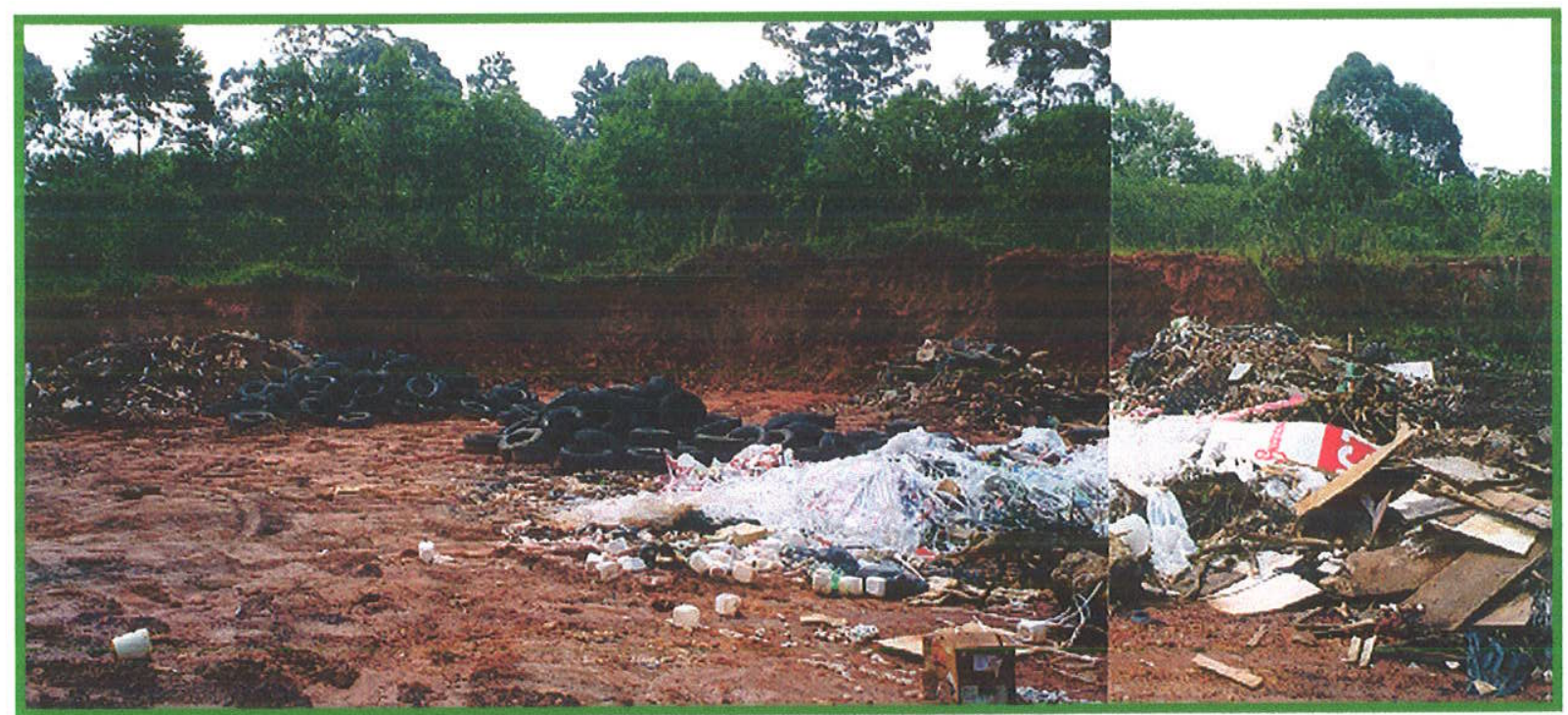

Figura 46 - Ponto de descarte de resíduos sólidos onde se observam pneus, materiais plásticos (potes e fitas) e entulho (madeira e terra). (Figura 44 - ponto 3 ) 


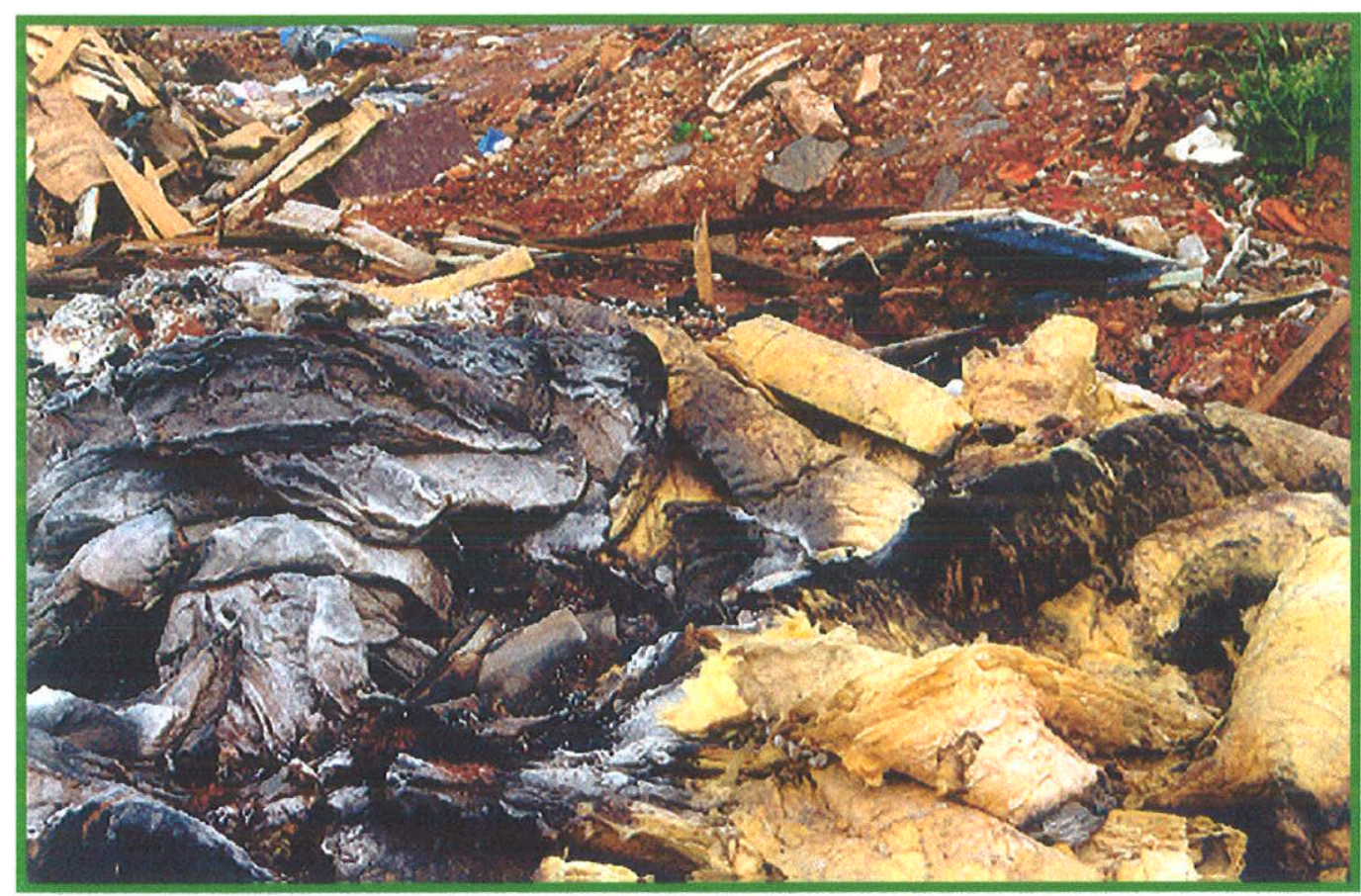

Figura 47 - Lã de vidro parcialmente queimada disposta irregularmente num ponto de descarte de resíduos próximo à estrada U. (Figura 44 - ponto 4)

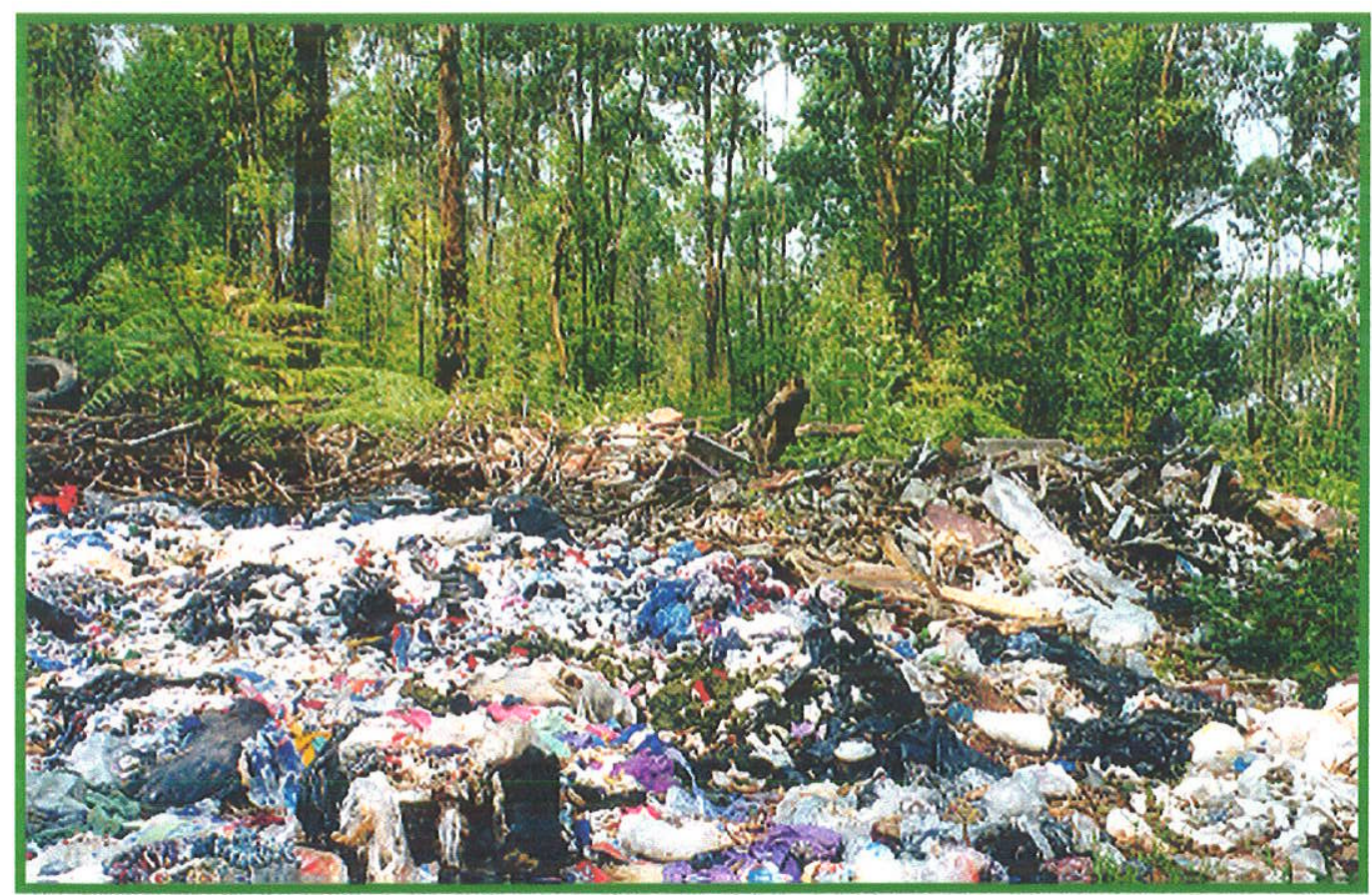

Figura 48 - Ponto de descarte de resíduos na margem da estrada $U$, com disposição irregular de meias, embalagens plásticas e troncos de árvore. No fundo, reflorestamento de eucaliptos. (Figura 44 - ponto 5) 
disposição irregular de resíduos sólidos), deve-se ressaltar também os postos de serviços e um cemitério (Figura 44), embora não se tenha conhecimento de problemas de vazamento de tanques nestes postos.

\section{3 - Levantamento hidrogeológico}

\subsection{1 - Cadastramento de poços e pontos d’água}

Conforme já mencionado no capítulo 4 (item 4.3.1), no total foram cadastrados 131 (cento e trinta e um) poços na área de estudo, sendo 98 (noventa e oito) poços cacimbas e 33 (trinta e três) poços tubulares, além de 6 (seis) fontes distribuidos por toda a área (Figura 49). Nove dos poços tubulares encontram-se desativados, devido ou à baixa produtividade ou a problemas com as respectivas bombas, enquanto somam 11 (onze) os poços cacimbas desativados, principalmente devido a chegada da rede de água da SABESP.

Os poços tubulares pertencem a estabelecimentos industriais $(41 \%)$, comerciais $(34,5 \%)$, rurais (sitios, chácaras e granjas) $-9,5 \%$, educacionais $(6 \%)$, recreativos $(3 \%)$, entre outros (6\%) instalados na área (Figura 50). O uso das águas é bem variado, abrangendo atividades industriais (processos industriais e limpeza), consumo doméstico (uso geral e potável), irrigação de flores, criação de peixes e dosagem de concreto. A retirada da água dos poços é feita através de bombas elétricas localizadas a diferentes profundidades dentro dos poços (Anexo 3 - Tabela 1). A maior parte dos poços foi construída na década de 90, no entanto, alguns já existem há mais de vinte anos (Anexo 3 Tabela 1).

Os poços cacimbas (escavados) estão distribuídos entre muitas indústrias (39\%), estabelecimentos comerciais (32\%), rurais (sítios, chácaras e granjas) - $16 \%$, educacionais $(7 \%)$, recreativos $(2 \%)$, entre outros $(4 \%)$ instalados na área (Figura 51$)$. A água é utilizada tanto para consumo doméstico como industrial, abrangendo as seguintes atividades: atividades industriais (processos industriais e limpeza), fabricação de blocos de concreto, consumo doméstico (uso geral e potável), cultivo de hortaliças, criação de animais (aves e peixes) e irrigação. Assim, como nos poços tubulares, a retirada de água da maioria das cacimbas é feita através de bombas elétricas instaladas no interior dos poços. Os poços mais antigos datam das décadas de 30 e 40, sendo a maioria construídos a partir da década de 70 (Anexo 3 - Tabela 2). 


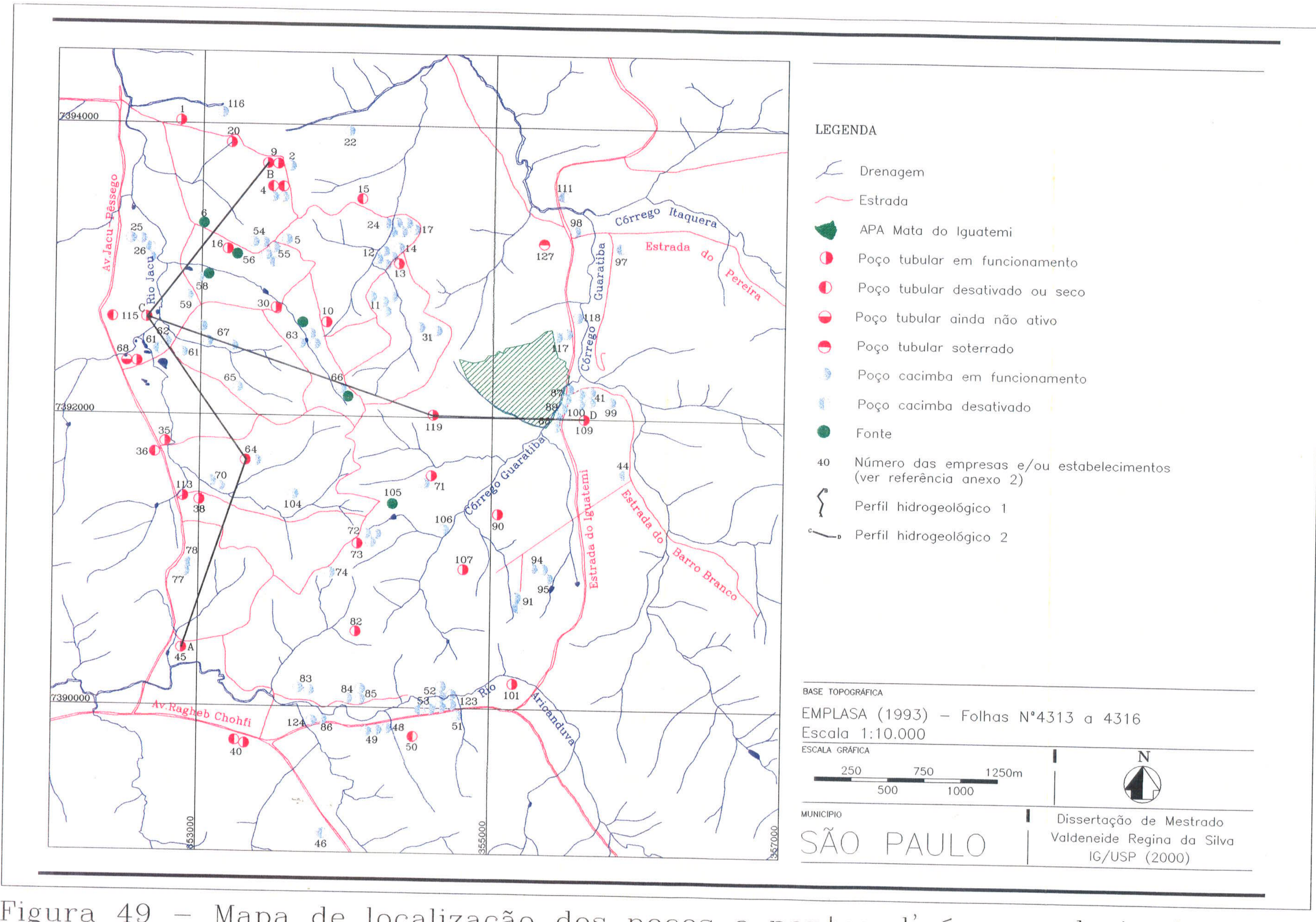

Figura 49 - Mapa de localização dos poços e pontos d’água cadastrados. 


\section{Poços Tubulares}

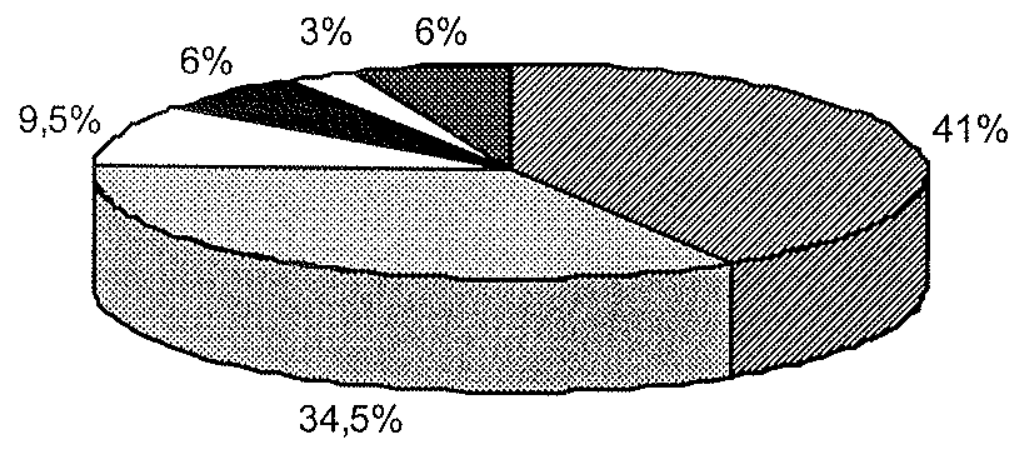

ind ustriais

圆comerciais

口rurais

educacionais

口recreativos

圆outros

Figura 50 - Distribuição dos poços tubulares de acordo com os tipos de estabelecimentos instalados na área.

\section{Poços Cacimbas}

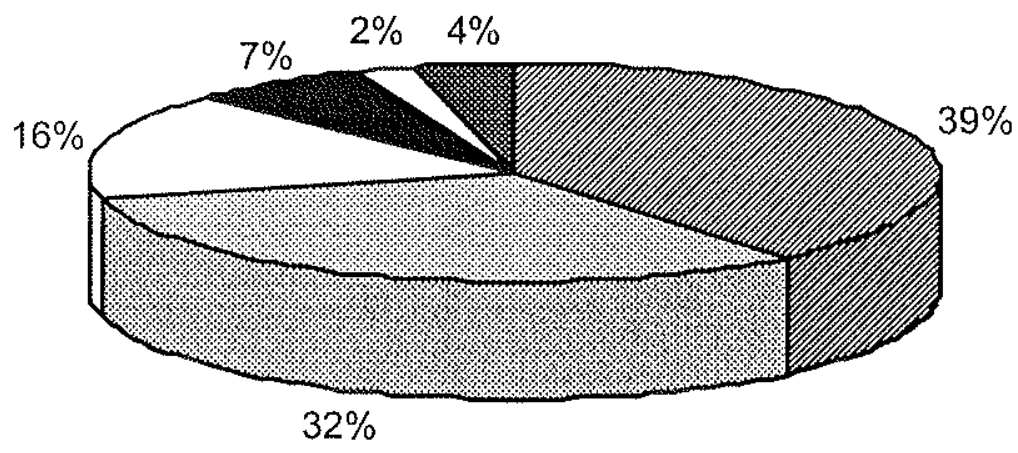

园 ind ust riais

圆comerciais

口rurais

meducacionais

口recreativos

圆outros

Figuras 51 - Distribuição dos poços cacimbas de acordo com os tipos de estabelecimentos instalados na área. 
As 6 (seis) fontes de água cadastradas foram encontradas em terrenos de indústrias (duas), chácaras (três) e granja (uma), sendo amplamente utilizadas inclusive para consumo humano.

\subsubsection{1 - Características dos poços}

\subsubsection{1 - Profundidade}

A profundidade média dos poços tubulares é de $183,0 \mathrm{~m}$, variando entre 80 e $350 \mathrm{~m}$. Contudo a maior freqüência $(30 \%)$ das profundidades encontram-se entre 134 e $188 \mathrm{~m}$, classe que inclui a média (Figura 52). Quanto aos poços cacimbas, a profundidade média é de $9,30 \mathrm{~m}$, variando entre 2,47 e $32,20 \mathrm{~m}$, no entanto a classe que contém a média representa apenas $18 \%$ das profundidades, conforme se observa na Figura 53.

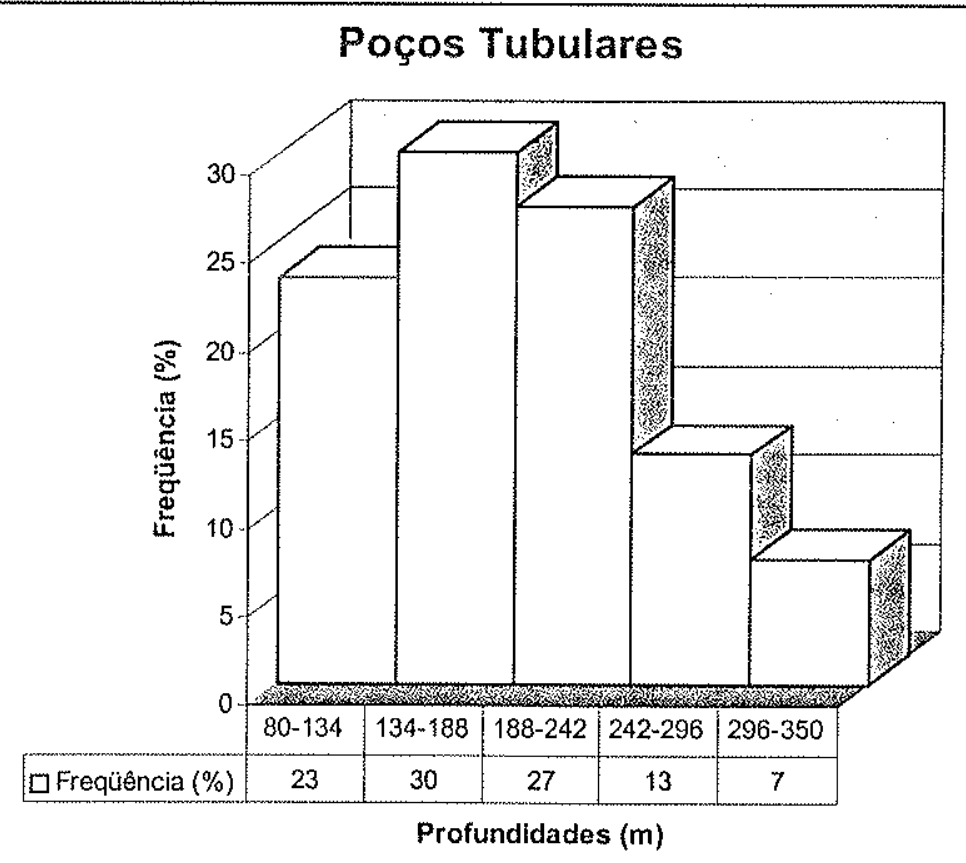

Figura 52 - Freqüência de distribuição das profundidades dos poços tubulares. (número de poços $=30$ )

\subsubsection{2 - Aspectos construtivos e de conservação dos poços}

A análise dos perfis construtivos dos poços tubulares revelou que os poços possuem revestimento interno de tubo de aço preto (diâmetro entre 101,6 e $317,5 \mathrm{~mm}$ ) e/ou de tubo 


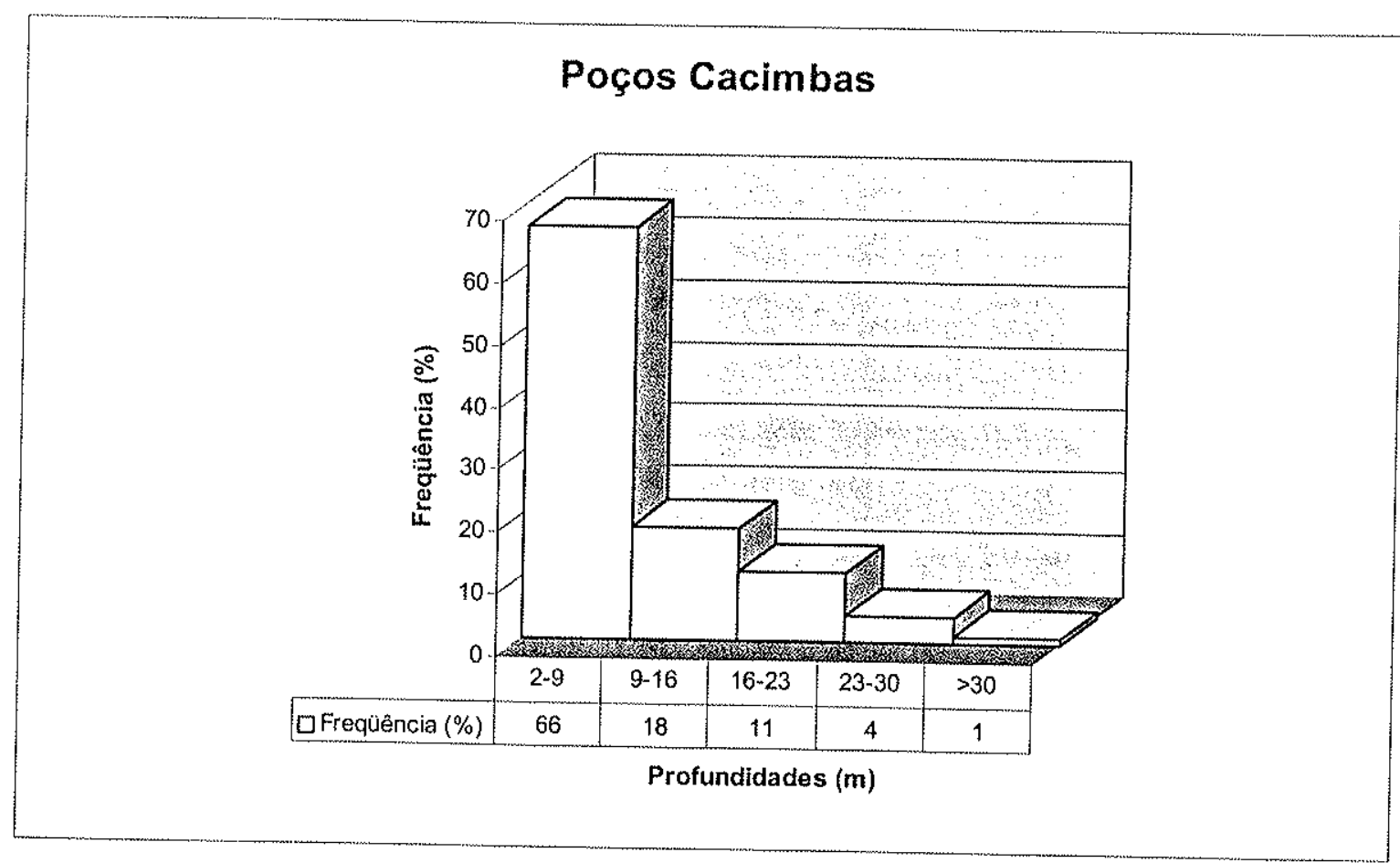
Figura 53 - Freqüência de distribuição das profundidades dos poços cacimbas. (número de
poços $=89$ )

de aço galvanizado (diâmetro de $152,4 \mathrm{~mm}$ ) em quase todo o trecho de solo e rocha intemperizada, chegando a penetrar de 1 (um) a 4 (quatro) metros na rocha sã, em alguns poços. Além do revestimento apresentam também cimentação, geralmente acompanhando a profundidade do revestimento, podendo estar alguns centímetros, ora abaixo, ora acima (poços 64, 109 e 115) do contato manto de intemperismo/rocha sã. Dentre os poços analisados, apenas 1 (um) contém filtro (poço 109) no trecho de rocha intemperizada, localizado a 2 (dois) metros acima do topo da rocha sã, num intervalo de mais de 12 (doze) metros. Neste poço, tanto o revestimento interno como a cimentação atingem menores profundidades, não alcançando a rocha sã. Este poço apresenta também pré-filtro do tipo jacarei. No geral, o primeiro diâmetro perfurado dos poços varia de $203,2 \mathrm{~mm}$ (8") a 374,6 $\mathrm{mm}(143 / 4 ")$.

Quanto aos poços cacimbas, o diâmetro varia de 0,80 a 3,0 m. Foram observados em campo muitos poços bem construídos, revestidos internamente por anéis de concreto prémoldados (manilhas) e externamente por muro de proteção de cimento ou concreto. Por outro lado, alguns poços ou são revestidos internamente de tijolos ou, então, não apresentam nenhum tipo de revestimento. Os poços, muitas vezes, estão situados dentro de cômodos fechados construidos especialmente para èles e, algumas vezes, dentro dos prédios (poços 11(1); 41(1); 52(1), 71 e 104) ou são protegidos por muretas construidas com 
blocos de concreto ou tijolo (poços 63(1); 66; 67(2 e 3) e 86). Apesar desses cuidados, os poços 55(1) e 55(2) situados em cômodos fechados encontravam-se em ambiente sujo.

Todos os poços apresentam algum tipo de tampa, geralmente de cimento ou concreto, ou são cobertos apenas por pedaços de madeira e de telha (poços 41(2); 51; 70(1); 78; 85(1 e 2$) ; 87(2) ; 88(1) ; 95 ; 100(1) ; 117(1)$ e 118$)$, o que facilita o ingresso de sujeira e de poluentes para dentro dos poços (Figura 54). As tampas de cimento ou concreto são, às vezes, fechadas com cadeado (poços 61 e 91), enquanto outras são fixas possuindo apenas um furo para a passagem da mangueira da bomba (poços 86 e 124).

A manutenção dos poços cacimbas (Anexo 3 - Tabela 2) refere-se à limpeza esporádica dos mesmos (semestral ou anual), onde são limpos as paredes e os fundos dos poços, com adição de cal virgem. Entretanto, durante os trabalhos de campo alguns poços estavam sujos internamente, com presença de vegetação nas paredes (poço 25(1)) e de lama no fundo (poço $52(3)$ ).

Ressalta-se, porém, que nem todas as águas dos poços maus construídos e conservados são utilizadas para consumo humano, o que será abordado no item 5.3.2.5 deste capítulo.

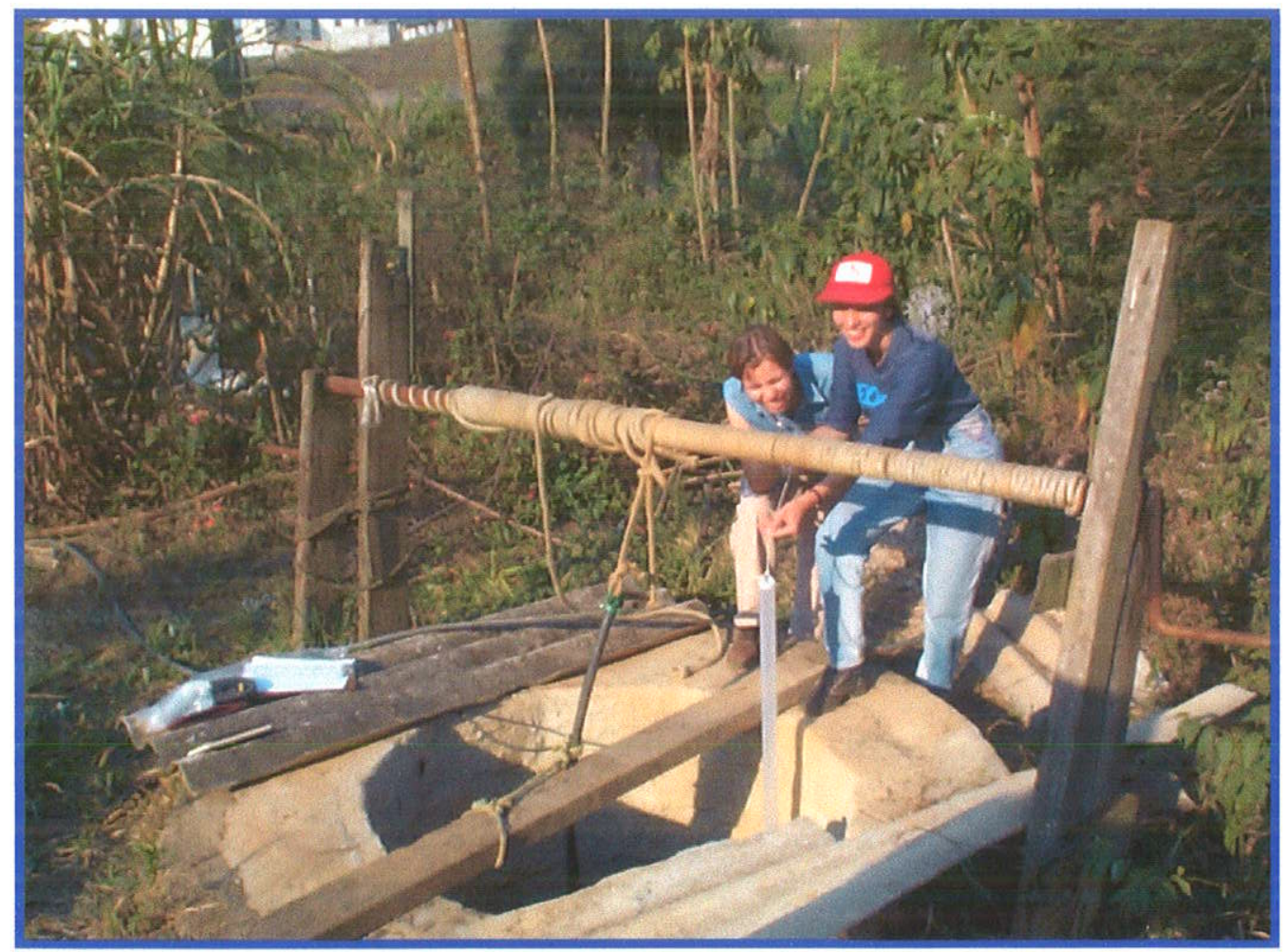

Figura 54 - Aspecto de preservação do poço 95 - Recicladora de Sucatas Rodoplast, mostrando o uso de pedaços de telha para cobrir o poço na ausência de tampa. 


\subsubsection{2 - Produção dos poços}

\subsubsection{1 - Vazão e capacidade específica}

A análise dos dados de vazão dos poços tubulares revelou valores que variam de 1,16 a $15,70 \mathrm{~m}^{3} / \mathrm{h}$, cuja média geral é de $4,44 \mathrm{~m}^{3} / \mathrm{h}$, sendo a média no granito-gnaisse de 3,58 $\mathrm{m}^{3} / \mathrm{h}$ e nos filitos e xistos de $4,65 \mathrm{~m}^{3} / \mathrm{h}$. Dentre os 15 (quinze) dados analisados, as três melhores vazões são de poços (poços 38 e 40,71,119) que explotam água dos filitos e xistos. Esses valores foram obtidos através de testes de vazão dos poços efetuados pelas companhias perfuradoras e não correspondem à vazão de uso dos mesmos, cujo valor médio é de $2,56 \mathrm{~m}^{3} / \mathrm{h}$ por poço tubular (Anexo 3 - Tabela 1).

Os valores de capacidade especifica destes poços mostraram grande variação, com valores situados entre 0,005 e $0,139 \mathrm{~m}^{3} / \mathrm{h} . \mathrm{m}$ (Tabela 5), porém extremamente baixos, indicando que para se obter uma vazão constante são necessários muitos metros (até 206 $m$ - poço 20) de rebaixamento do nivel d'água.

Tabela 5 - Valores de vazão e capacidade específica dos pocos tubulares.

\begin{tabular}{|c|c|c|c|c|c|c|}
\hline № Empresa & Prof.Poco $(\mathrm{m})$ & Vazão $\left(\mathrm{m}^{3} / \mathrm{h}\right)$ & $\mathrm{NE}(\mathrm{m})$ & NE (mês/ano) & ND $(\mathrm{m})$ & Cap. Especifica $\left(\mathrm{m}^{3} / \mathrm{h} . \mathrm{m}\right)$ \\
\hline $9(1)$ & 255 & 4,70 & 4,00 & 5 a $7 / 74$ & 147,00 & 0,032 \\
\hline $9(2)$ & 200 & 4,90 & 2,00 & 6 a $7 / 75$ & 120,00 & 0,041 \\
\hline 20 & 350 & 1,16 & 12,00 & $8 / 96$ & 218,00 & 0,005 \\
\hline 30 & 80 & 2,00 & & & & \\
\hline 36 & 164 & 3,77 & 10,00 & & 60,00 & 0,063 \\
\hline 38 & 206 & 6,00 & & & & \\
\hline 40 & 170 & 6,00 & 24,00 & & 86,00 & 0,069 \\
\hline 45 & 140 & 2,00 & 6,00 & & 82,00 & 0,024 \\
\hline 64 & 162 & 2,50 & 61,30 & & 139,50 & 0,018 \\
\hline $71(1)$ & 240 & 8,80 & 9,70 & 5 a $8 / 98$ & 155,36 & 0,056 \\
\hline 82 & 140 & 3,50 & & & & \\
\hline 90 & 120 & 1,50 & 40,00 & & & \\
\hline 109 & 333 & 2,40 & 10,00 & $2 / 94$ & 171,00 & 0,014 \\
\hline $115(1)$ & 244 & 1,67 & 8,50 & $6 a 7 / 97$ & 129,98 & 0,013 \\
\hline 119 & 204 & 15,70 & 10,12 & $8 / 97$ & 112,23 & 0,139 \\
\hline
\end{tabular}

Cap. = Capacidade; № = Número; ND = Nivel Dinâmico; NE = Nivel Estático; Prof. = Profundidade.

\subsubsection{3 - Características dos aqüíferos}

\subsubsection{3 .1 - Profundidade das entradas de água}

Com base nos perfis litológicos dos poços, elaborados pelas empresas perfuradoras, foram encontradas indicações de entradas de água em 3 (três) perfis através da presença de filtro no manto de intemperismo (poço 109) e de fraturas na rocha sã (poços 9 (1) e 115). 
No primeiro caso (poço 109), a entrada de água situa-se entre as profundidades de 41 e $53 \mathrm{~m}$, em mica-xisto, na zona de transição manto intemperizado/rocha sã e, no segundo caso, foram verificadas entradas nas seguintes profundidades: 75 a $85 \mathrm{~m}$ e de 178 a $192 \mathrm{~m}$ (poço $9(1)$ ) e a $145 \mathrm{~m}$ (poço 115 (1)), em poços perfurados em granito-gnaisse (Figuras 55 e 56).

\subsubsection{2 - Nível estático}

Os niveis estáticos dos poços tubulares foram obtidos principalmente através das fichas técnicas do poços e, secundariamente, através de informação verbal. Os niveis foram medidos em épocas diferentes, logo após a perfuração dos poços na ocasião da realização dos testes de bombeamento, conforme indicados na Tabela 5. Como se observa nesta tabela, alguns niveis estáticos foram medidos durante o periodo mais seco do ano (abril a setembro), e outro (poço 109) no periodo chuvoso (outubro a março). Quanto às profundidades, variaram entre 2,0 e 61,3 m entre todos os niveis obtidos (Anexo 3 - Tabela 1).

Quanto aos poços cacimbas, a maioria dos dados foi obtida através da leitura no campo durante o período de agosto/setembro/99 (período seco). Conforme se observa no Anexo 3 - Tabela 2 , os niveis variaram entre 0,13 e $29,80 \mathrm{~m}$.

\subsection{2 -Análises químicas}

\subsubsection{1 - Verificação da validade das análises}

Uma das técnicas mais comuns utilizadas para se verificar o grau de precisão e confiabilidade das análises químicas consiste no envio de amostras duplicatas para o laboratório e posterior comparação dos resultados das análises. Esta técnica foi utilizada neste estudo, referente às amostras coletadas na $2^{\mathrm{a}}$ fase de coleta e os resultados obtidos foram em geral satisfatórios, com exceção das amostras 85(1) e 91 que apresentaram diferenças nas concentrações de cálcio da ordem de 4 e $10 \mathrm{mg} \cdot \mathrm{L}^{-1}$, respectivamente, entre as suas duplicatas.

A exatidão dos resultados de análise de água pode ser avaliada pelo cálculo do balanço iônico, realizado a partir das concentrações totais (em miliequivalentes por litro) dos cátions principais ( $\sum$ cátions) e as concentrações totais dos ânions principais ( $\sum$ ânions), que 


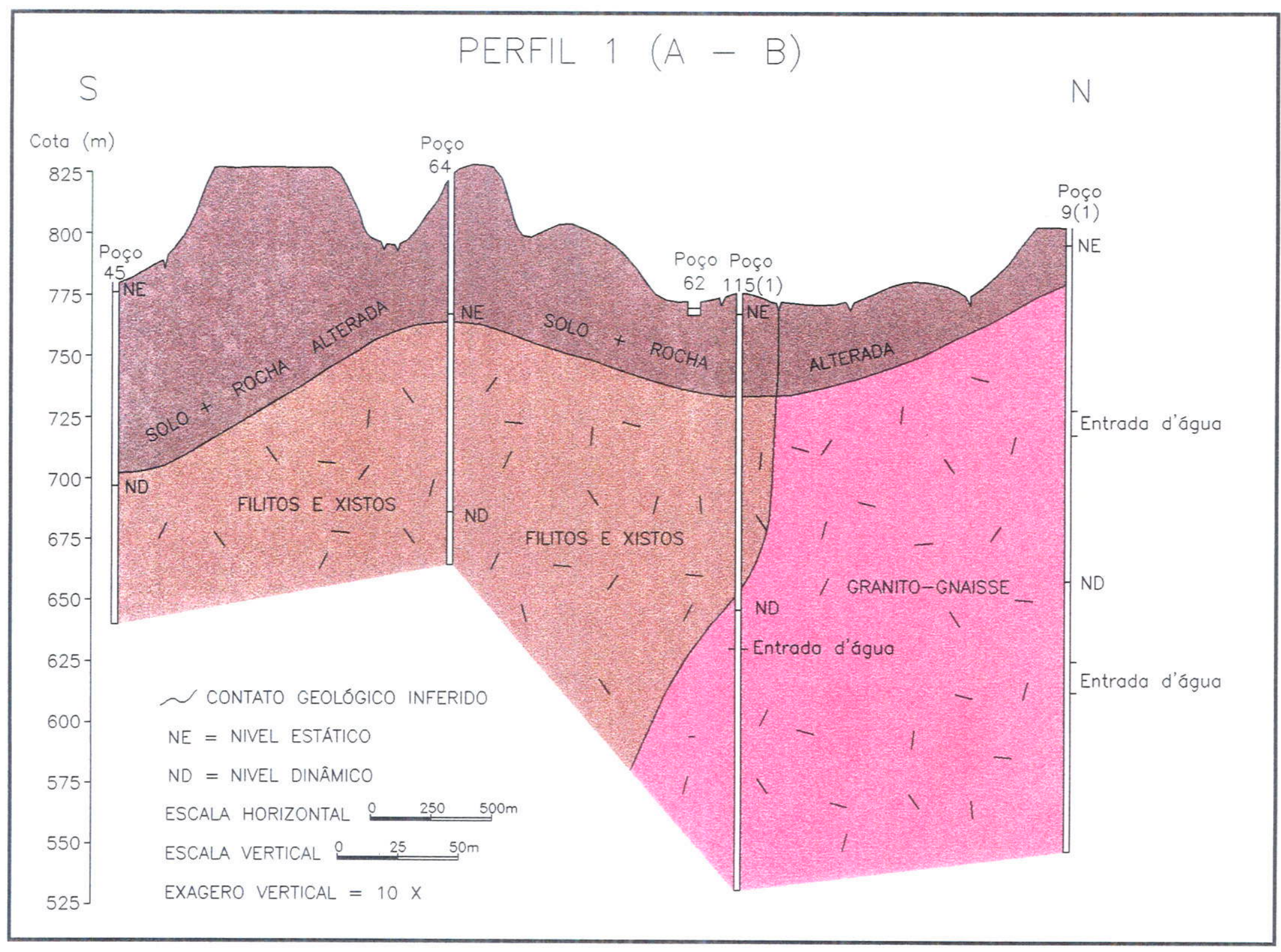

Figura 55 - Perfil hidrogeológico 1 (localização Figura 49). 


\section{PERFIL $2(C-D)$}

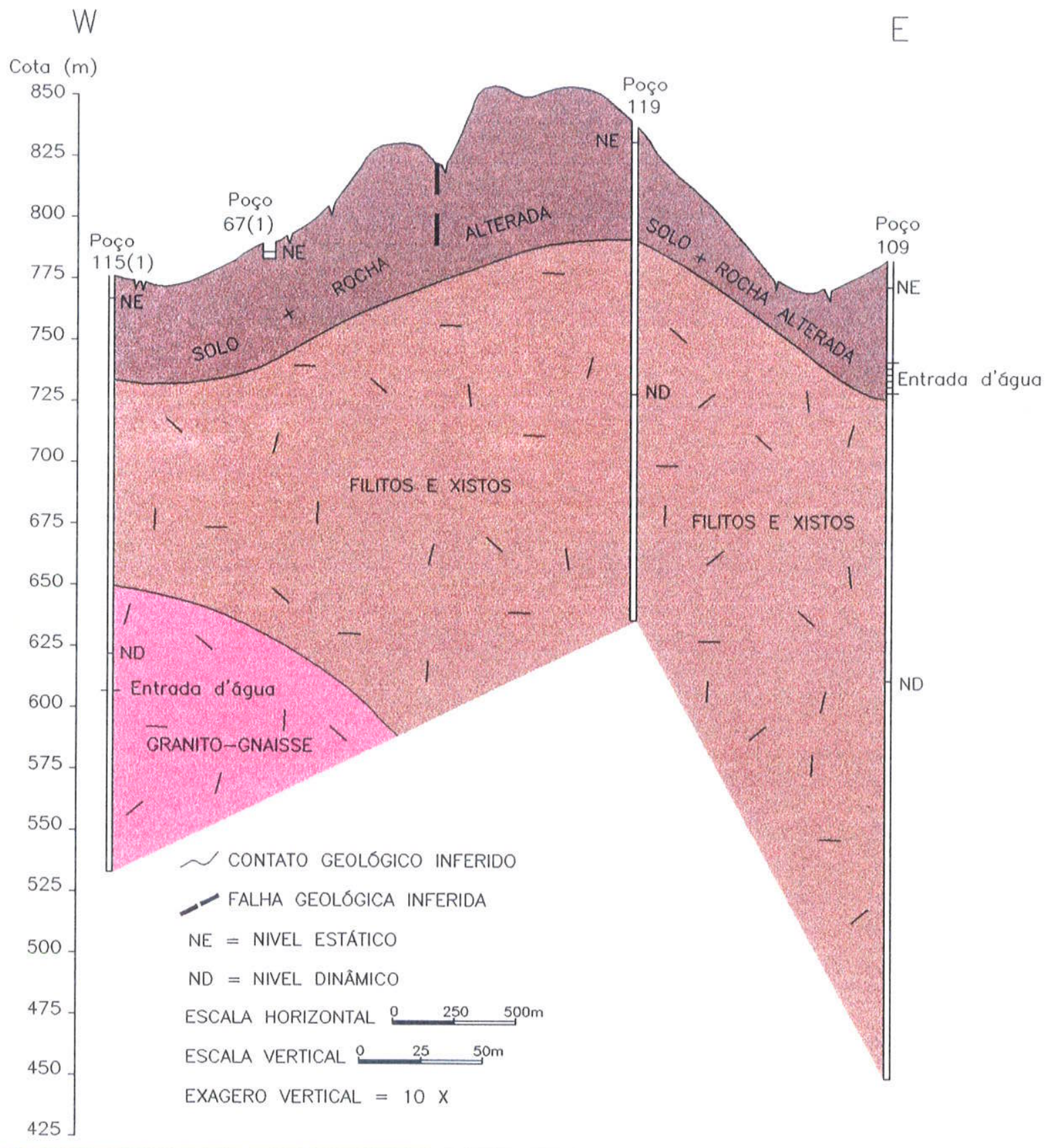

Figura 56-Perfil hidrogeológico 2 (localização Figura 49). 
devem ser aproximadamente iguais. O desvio percentual dessa igualdade é determinado pelo coeficiente de erro $(e)$ da análise representado por:

$$
e(\%)=\left(\frac{\sum \text { cátions }-\sum \text { ânions }}{\sum \text { cátions }+\sum \hat{\text { ânions }}}\right) \times 100
$$

Na prática a diferença que existe entre as concentrações totais de cátions e as concentrações totais de ânions é devida aos erros acumulados de cada determinação individual e ao fato de não se ter levado em conta as concentrações iônicas menores. Se ocorre uma diferença muito grande é devido a existência de quantidades anormais de ions menores ou a um erro grave de análise (CUSTODIO \& LLAMAS, 1996).

Em geral, o balanço iônico admite um erro de no máximo $\pm 10 \%$ para que a análise seja aceita, embora seja admissivel erros de até $30 \%$, no caso de águas com baixas condutividades elétricas (ao redor de $50 \mu \mathrm{S} / \mathrm{cm}$ ), conforme indicado em CUSTODIO \& LLAMAS (1996).

O cálculo do balanço iônico foi efetuado de 3 (três) formas diferentes em função dos cátions e ânions escolhidos, conforme discriminados a seguir:

a) somente os ions principais: cátions $\left(\mathrm{Ca}^{2+}, \mathrm{K}^{+}, \mathrm{Mg}^{2+}, \mathrm{Na}^{+}\right)$e ânions $\left(\mathrm{HCO}_{3}^{-}, \mathrm{NO}_{3}\right.$, $\left.\mathrm{SO}_{4}{ }^{2-}\right)$

b) todos os cátions e ânions anteriores, incluindo o ferro $\left(\mathrm{Fe}^{2+}\right)$ e o cloreto $\left(\mathrm{Cl}^{-}\right)$;

c) todos os cátions e ânions analisados.

Além disso, devido as concentrações de bicarbonato das águas terem sido calculadas a partir da alcalinidade determinada parcialmente em laboratório ( $1^{\mathrm{a}}$ fase) e parcialmente em campo ( $2^{a}$ fase), os erros analíticos serão apresentados de acordo com as fases de coleta na Tabela 6.

A tabela 6 mostra que na $2^{\text {a }}$ fase um número maior de amostras indicou erros acima de $10 \%$ comparado com a $1^{\text {a }}$ fase e que os resultados obtidos não mostraram grandes variações em função das diferentes formas de cálculo do balanço iônico, principalmente na $2^{\mathrm{a}}$ fase, quando era esperado valores de erro bem menores de acordo com a $3^{\text {a }}$ forma, que considerou todos os cátions e ânions analisados e mais o bicarbonato. Estes fatos sugerem 
Tabela 6 - Resultados de erros analíticos obtidos através das diferentes formas de cálculo do balanço iônico em relação às fases de coleta (dados em porcentagem de número de amostras).

\begin{tabular}{|c|c|c|c|c|c|}
\hline Fases & Formas & $\begin{array}{c}\mathrm{N}_{-}^{o} \text { de } \\
\text { amostras }\end{array}$ & $e \leq 10 \%$ & $10 \%<\mathrm{e} \leq 30 \%$ & e $>30 \%$ \\
\hline \multirow{3}{*}{ 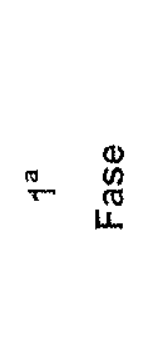 } & $1^{\mathrm{a}}$ forma & \multirow{3}{*}{24} & $54 \%$ & $41 \%$ & $4 \%$ \\
\hline & $2^{\text {a }}$ forma & & $42 \%$ & $58 \%$ & $0 \%$ \\
\hline & $3^{a}$ forma & & $46 \%$ & $50 \%$ & $4 \%$ \\
\hline \multirow{3}{*}{ 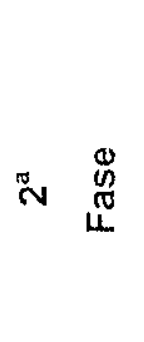 } & $1^{2}$ forma & \multirow{3}{*}{10} & $30 \%$ & $70 \%$ & $0 \%$ \\
\hline & $2^{\mathrm{a}}$ forma & & $30 \%$ & $70 \%$ & $0 \%$ \\
\hline & $3^{a}$ forma & & $30 \%$ & $70 \%$ & $0 \%$ \\
\hline
\end{tabular}

que um dos principais motivos de erros analíticos tão elevados, tanto na $1^{\text {a }}$ como na $2^{\text {a }}$ fase de coleta, é devido às imprecisões na determinação da alcalinidade (uso de conta-gotas), a partir da qual se obteve o ion bicarbonato, visto que pequenas variações nas concentrações deste ín podem levar a valores de erros no balanço iônico muito grandes, principalmente quando ele. constitui um dos ânions mais abundantes. Somam-se a isso as baixas concentrações iônicas das amostras, com exceção de algumas concentrações elevadas de nitrato, ferro, alumínio, manganês, brometo e potássio que serão comentadas adiante.

\subsubsection{2 - Parâmetros físicos}

\subsubsection{1 - Temperatura}

A temperatura das águas subterrâneas é muito pouco variável e corresponde à média anual das temperaturas atmosféricas locais (CUSTODIO \& LLAMAS, 1996). Na área de estudo as temperaturas das águas variaram entre 21,2 e $26,0{ }^{\circ} \mathrm{C}$, tendo uma boa aproximação com a temperatura atmosférica média anual da RMSP, que é de $25,0^{\circ} \mathrm{C}$. 


\subsubsection{2 - Condutividade elétrica}

A condutividade elétrica representa a capacidade da água em transmitir corrente elétrica, sendo influenciada pela temperatura, tipo e concentração de lons dissolvidos (CUSTODIO \& LLLAMAS, 1996).

As condutividades elétricas das águas analisadas foram determinadas de duas maneiras: $50 \%$ em campo com o uso do condutivimetro e $50 \%$ em laboratório, utilizando-se as seguintes fórmulas expressas em CUSTODIO \& LLAMAS (1996).

\begin{tabular}{ll}
\hline Fórmula & Valor de $\mathbf{M}$ \\
\hline$C=100 M$ & $<1,0$ \\
$C=12,27+86,38 M+0,835 M^{2}$ & 1,0 a 3,0 \\
$C=M(95,5-5,54 \log M)$ & 3,0 a 10,0 \\
\hline
\end{tabular}

onde:

$\mathrm{M}=$ conteúdo total em ânions ou cátions (tomar a semisoma) (em meq. L."1 $)$.

$\mathrm{C}=$ condutividade elétrica em $\mu \mathrm{S} / \mathrm{cm}$ a $25^{\circ} \mathrm{C}$.

De um modo geral as condutividades elétricas obtidas variaram entre 22 e $321 \mu \mathrm{S} / \mathrm{cm}$ (Tabela 7), sendo ambos os valores encontrados nas águas dos poços cacimbas escavados em granito-gnaisse. Dentre as águas dos poços tubulares (40, 45 e 109), perfurados em filitos e xistos, os valores de condutividade elétrica se situaram entre 90 e $120 \mu \mathrm{S} / \mathrm{cm}$, enquanto a condutividade elétrica da fonte (63(4)) localizada em área granítica foi de 136 $\mu S / \mathrm{cm}$.

Como as águas subterrâneas mais profundas em geral são mais mineralizadas que as águas rasas devido às maiores oportunidades de dissolver sais, seriam esperados valores de condutividade elétrica maiores nas águas dos poços tubulares e não nas dos poços cacimbas, como foi observado, principalmente quando se compara águas provindas de aqüíferos de mesma formação litológica. Porém, como em aqüiferos porosos (permeabilidade de poros) o contato rocha/água é mais intenso favorecendo o aporte de sais mais rapidamente para as águas, em comparação com os aqüiferos fraturados 
Tabela 7 - Condutividades elétricas das águas da área de estudo.

\begin{tabular}{|c|c|c|}
\hline Poço & Cond. elétrica a 25 $\mathbf{0}^{\circ} \mathrm{C}(\boldsymbol{\mu S} / \mathrm{cm})$ & Litologia \\
\hline 25 & 321 & granito-gnaisse \\
\hline $31(1)$ & $110^{*}$ & filitos e xistos \\
\hline $31(2)$ & $60^{*}$ & filitos e xistos \\
\hline $40^{\dagger}$ & $120^{*}$ & filitos e xistos \\
\hline 41 & 33 & filitos e xistos \\
\hline $45^{\dagger}$ & 105 & filitos e xistos \\
\hline $63(1)$ & 22 & granito-gnaisse \\
\hline $63(2)$ & 56 & granito-gnaisse \\
\hline $63(3)$ & 27 & filitos e xistos \\
\hline $63(4)$ & 136 & granito-gnaisse \\
\hline $67(1)$ & $50^{*}$ & filitos e xistos \\
\hline $67(2)$ & $80^{*}$ & filitos e xistos \\
\hline $67(3)$ & $100^{*}$ & filitos e xistos \\
\hline $71(1)$ & $130^{*}$ & filitos e xistos \\
\hline $85(1)$ & $270^{*}$ & filitos e xistos \\
\hline $85(2)$ & $100^{*}$ & filitos e xistos \\
\hline 87 & $230^{*}$ & filitos e xistos \\
\hline $88(1)$ & 60 & filitos e xistos \\
\hline $88(2)$ & 107 & filitos e xistos \\
\hline 91 & $50^{*}$ & filitos e xistos \\
\hline 95 & $90^{*}$ & filitos e xistos \\
\hline $100(1)$ & $40^{*}$ & filitos existos \\
\hline $109^{\dagger}$ & 90 & filitos e xistos \\
\hline $117(1)$ & 80 & filitos e xistos \\
\hline $117(2)$ & 69 & filitos e xistos \\
\hline 118 & 43 & filitos e xistos \\
\hline
\end{tabular}

Cond $=$ condutividade

* condutividade determinada em campo

${ }^{t}=$ poço tubular 
(permeabilidade de fraturas) (CUSTODIO \& LLAMAS, 1996), este pode ser o motivo pelo qual os valores de condutividade elétrica foram mais elevados nas águas dos poços cacimbas, uma vez que estão situados no manto de intemperismo, que além da permeabilidade de fraturas apresenta também permeabilidade de poros.

\subsubsection{3 - Parâmetros químicos}

Conforme exposto no capítulo 4 (item 4.3.2) foram analisadas 38 (trinta e oito) amostras de água subterrânea em duas fases. Os resultados obtidos (Anexo 4 - Tabelas 1 e 2) mostram que, no geral, as águas apresentam baixas concentrações de ions quando comparadas com os valores mais frequentemente encontrados nas águas doces subterrâneas (Tabela 8), com exceção do nitrato, ferro, aluminio, manganês, brometo e potássio.

Tabela 8 - Comparação entre as concentrações normais de íons nas águas doces subterrâneas, segundo CUSTODIO \& LLAMAS (1996), e as concentrações encontradas nas águas da área de estudo.

\begin{tabular}{|c|c|c|}
\hline \multicolumn{2}{|c|}{ CUSTODIO \& LLAMAS (1996) } & Dados da atual pesquisa \\
\hline Íons Fundamentais & $\begin{array}{l}\text { Concentração normal em } \\
\text { água doce }\left(\mathrm{mg} \cdot \mathrm{L}^{-1}\right)\end{array}$ & Concentração (mg.L.1-1) \\
\hline $\mathrm{HCO}_{3}$ & 50 a 350 & 3,26 a 146,98 \\
\hline $\mathrm{Cl}^{r}$ & 10 a 250 & 1,44 a 20,76 \\
\hline $\mathrm{SO}_{4}^{2-}$ & 2 a 150 & 0,16 a 14,75 \\
\hline $\mathrm{Ca}^{2+}$ & 10 a 250 & 0,10 a 70,50 \\
\hline $\mathrm{Na}^{+}$ & 1 a 150 & 0,50 a 18,00 \\
\hline $\mathrm{Mg}^{2+}$ & 1 a 100 & 0,10 a 7,35 \\
\hline Íons Menores & $\begin{array}{l}\text { Concentração normal em } \\
\text { água doce }\left(\mathrm{mg} \cdot \mathrm{L}^{-1}\right)\end{array}$ & Concentração (mg. $\left.\mathrm{L}^{-1}\right)$ \\
\hline $\mathrm{Fe}^{2+}$ & 0 a 10 & 0,01 a 16,48 \\
\hline $\mathrm{NO}_{3}^{-}$ & 0,1 a 10 & 0,04 a 141,64 \\
\hline $\mathrm{K}^{+}$ & 0,1 a 10 & 0,10 a 13,60 \\
\hline$F^{-}$ & 0,1 a 1 & 0,001 a 0,360 \\
\hline $\mathrm{PO}_{4}^{3-}$ & 0,01 a 1 & 0,008 a 0,100 \\
\hline $\mathrm{Sr}^{2+}$ & 0,01 a 1 & 0,01 a 0,34 \\
\hline $\mathrm{Al}^{3+}$ & 0,005 a 0,3 & 0,03 a 1,21 \\
\hline $\mathrm{Mn}^{2+}$ & $<0,2$ & 0,01 a 1,49 \\
\hline $\mathrm{Br}^{-}$ & $<0,01$ & 0,005 a 1,050 \\
\hline
\end{tabular}




\subsubsection{1 - pH e Eh}

A determinação destes parâmetros em campo requer que seja éretuada com rapidez, pois tanto um como o outro podem sofrer variações muito grandes quando a amostra é colocada em contato com a atmosfera.

No caso do $\mathrm{pH}$, este contato pode provocar o desprendimento de certos gases dissolvidos na água (especialmente o gás carbônico) e com isso o aumento do $\mathrm{pH}$ em relação ao original afetando a solubilidade de vários elementos, tais como o cálcio, magnésio e metais pesados (FOSTER \& GOMES, 1989). Os valores de $\mathrm{pH}$ das águas obtidos neste estudo (Anexo 4 - Tabelas 1 e 2) e provenientes dos poços cacimbas variaram de 4,50 a 6,86 evidenciando o caráter predominantemente ácido dessas águas.

No caso do Eh, as variações ocorrem em função do ingresso de oxigênio no sistema afetando a solubilidade de inúmeros elementos como o ferro, manganês, cromo e outros metais (FOSTER \& GOMES, 1989). Estes elementos quando oxidados precipitam-se na forma de hidróxidos, o que pode causar sérios problemas nos resultados obtidos, pois estas espécies devido a sua capacidade de adsorção podem promover uma redução na concentração de vários íons que se deseja analisar, principalmente as espécies reduzidas como $\mathrm{Fe}^{2+}, \mathrm{Cr}^{3+}$ e $\mathrm{Mn}^{2+}$. Os valores de Eh obtidos neste estudo (Anexo 4 - Tabela 1) provenientes de poços cacimbas se situaram entre $+0,49 e+0,63$.

Com base nos resultados de pH e Eh obtidos e através dos diagramas de oxi-redução, verificou-se que o ferro total das amostras está presente principalmente na forma de $\mathrm{Fe}(\mathrm{OH})_{3}^{-}$e subordinadamente como $\mathrm{Fe}^{2+}$ e que o cromo total apresenta-se predominantemente como $\mathrm{Cr}^{3+}$.

\subsubsection{2 - Alcalinidade}

A alcalinidade da água é a sua capacidade de neutralizar ácidos até um valor designado de $\mathrm{pH}$. Tem-se alcalinidade total ou completa (Titulação Alcalinimétrica Completa - TAC) e parcial (Titulação Alcalinimétrica - TA) que medem o conteúdo de ânions hidrolizáveis, principalmente dos ânions $\mathrm{HCO}_{3}, \mathrm{CO}_{3}{ }^{2-} \mathrm{e} \mathrm{OH}$.

A determinação das alcalinidades (total e parcial) é efetuada através de titulação de neutralização ácido/base, empregando ácido sulfúrico e indicadores colorimétricos com diferentes $\mathrm{pHs}$ de viragem, como verde de bromo-cresol $(\mathrm{pH}=4,5)$, fenolftaleína ( $\mathrm{pH}$ entre 8 e 10), indicador misto $(p H=5,1)$, etc. Quando se deseja um grau de precisão maior é 
recomendável que as determinações sejam feitas em campo, pois as realizadas em laboratório dão uma margem de erro de quase $5 \%$ em relação às primeiras (CUSTODIO \& LLAMAS, 1996).

Para águas com $\mathrm{pH}<8,3$ a $\mathrm{TA}=0$ e, neste caso, a $\mathrm{TAC}=\mathrm{HCO}_{3}^{-}$(em meq. $\mathrm{L}^{-1}$ ) (CUSTODIO \& LLAMAS, 1996), o que indica que as alcalinidades de $\mathrm{CO}_{3}^{2-}$ e $\mathrm{OH}^{-}$são insignificantes ou nulas. Neste estudo foi determinada apenas a TAC, devido aos valores baixos de $\mathrm{pH}(4,50$ a 6,86$)$, encontrando-se nas águas dos poços cacimbas valores situados predominantemente entre 2,67 e $48,18\left(m g \cdot \mathrm{L}^{-1}\right.$ de $\left.\mathrm{CaCO}_{3}\right)$ e excepcionalmente mais elevados na amostra 85(1), que apresentou na $1^{\mathrm{a}}$ e $2^{\mathrm{a}}$ fase de coleta valores de 80,32 e 120,48 mg.L. ${ }^{-1}$ de $\mathrm{CaCO}_{3}$, respectivamente (Anexo 4 - Tabelas 1 e 2), enquanto nos poços tubulares os teores estão entre 45,72 a $55,52 \mathrm{mg}^{-\mathrm{L}^{-1}}$.

A alcalinidade das águas foi determinada neste estudo com o objetivo de se obter as concentrações do ín bicarbonato, através da relação $\mathrm{HCO}_{3}{ }^{-}\left(\mathrm{mg} \cdot \mathrm{L}^{-1}\right)=1,22 \times \mathrm{TAC}\left(\mathrm{mg} \cdot \mathrm{L}^{-1}\right.$ de $\mathrm{CaCO}_{3}$ ) expressa em CUSTODIO E LLAMAS (1996).

\subsubsection{4 - Classificação das águas}

Dentre as amostras analisadas, 25 (vinte e cinco) tiveram suas alcalinidades determinadas, permitindo o cálculo da concentração de $\mathrm{HCO}_{3}$ " e assim a classificação segundo o diagrama de Piper (Figura 57), juntamente com os ânions $\mathrm{Cl}^{-}, \mathrm{NO}_{3}{ }^{-}$e $\mathrm{SO}_{4}{ }^{2-}$ e os cátions $\mathrm{Na}^{+}, \mathrm{K}^{+}, \mathrm{Ca}^{2+}, \mathrm{Mg}^{2+}$ obtidos analiticamente.

Numa primeira análise da Figura 57, nota-se que as águas apresentam uma ampla variação composicional evidenciada pela dispersão das amostras no diagrama. Contudo, verifica-se que há um predomínio das sulfatadas cálcicas e bicarbonatadas cálcicas, representadas principalmente pelas amostras provenientes de poços cacimbas. Por outro lado, as amostras provenientes de poços tubulares foram classificadas predominantemente como bicarbonatadas sódicas, mostrando um enriquecimento maior dos cátions $\mathrm{Na}^{+} \mathrm{e} \mathrm{K}^{+}$ que de $\mathrm{Ca}^{2+}$, e do ânion $\mathrm{HCO}_{3}{ }^{-}$em relação ao $\mathrm{Cl}^{-}$e $\mathrm{NO}_{3}{ }^{-}$.

As amostras cloretadas sódicas e sulfatadas cálcicas situadas no campo de predominância dos ânions $\mathrm{Cl}^{+}$e $\mathrm{NO}_{3}{ }^{\circ}$, ou seja, as amostras $25,31(1), 63(1), 63(2), 63(4)$, $67(3), 85(2), 95$ e 118, sugerem que haja contaminação das águas por nitrato. 


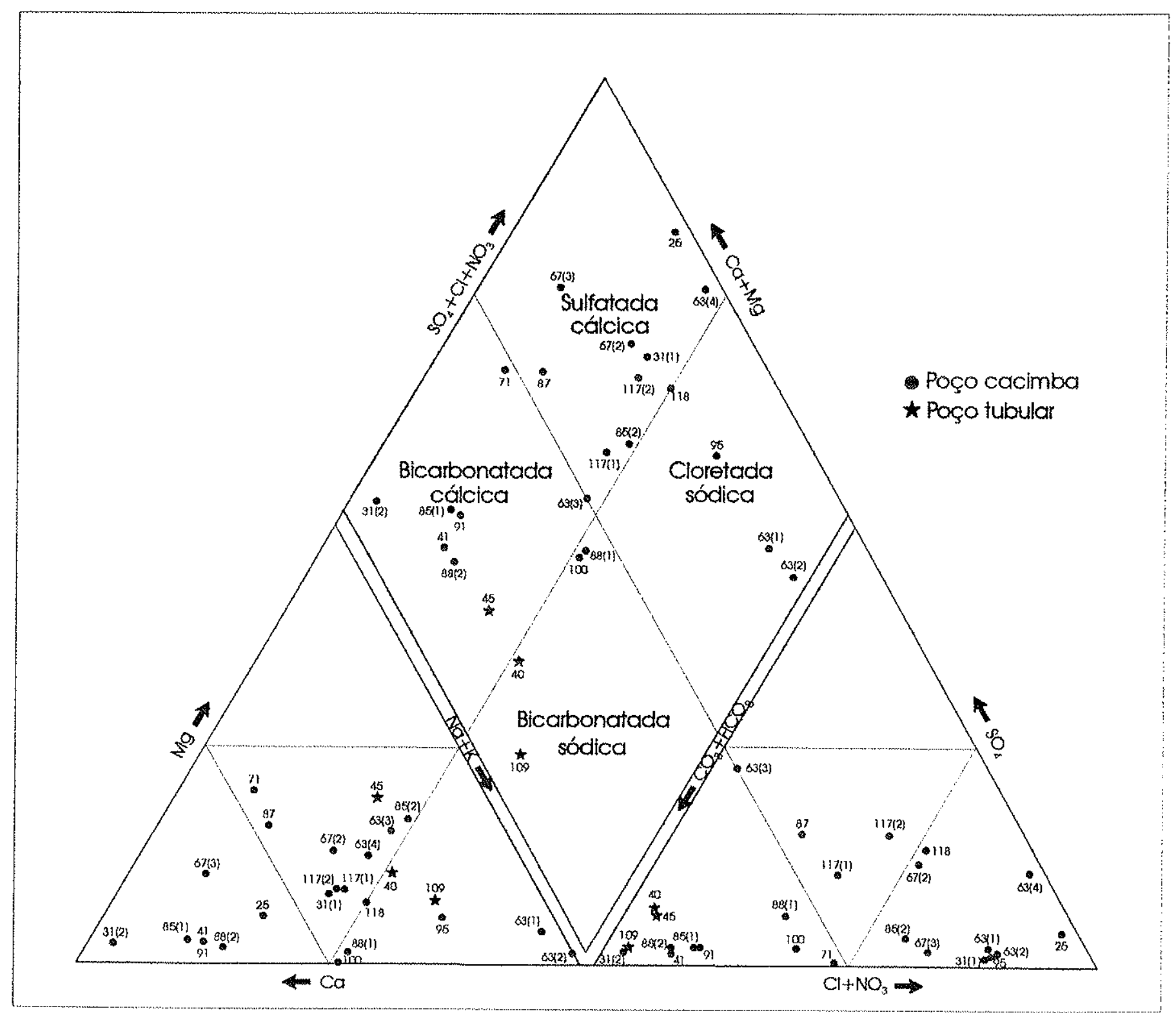

Figura 57 - Classificação química das águas subterrâneas da área de estudo. 


\subsubsection{5 - Qualidade das águas}

A qualidade da água é um conceito relativo que assegura um determinado uso ou conjunto de usos. Um dos principais objetivos em se avaliar as caracteristicas de uma água é constatar a observância ou violação dos padrões especificados para sua qualidade. Os padrões de potabilidade utilizados neste estudo foram os estabelecidos pela Portaria 36 (Ministério da Saúde - 19/01/90) e Organização Mundial da Saúde - OMS e o padrão estabelecido pela Resolução CONAMA (18/06/86) para abastecimento doméstico, irrigação, recreação e preservação de animais e plantas (Tabela 9).

Os resultados das análises quimicas das águas (Anexo 4 - Tabela 1 e 2) quando confrontados com os padrões de potabilidade revelam que várias amostras apresentaram teores de nitrato, ferro total, manganês e alumínio acima dos valores máximos permitidos para consumo humano e teores elevados de nitrato, manganês, alumínio, fosfato e zinco, quando confrontados com o padrão estabelecido pela Resolução CONAMA. Os valores de $\mathrm{pH}$ das amostras, em sua grande maioria, também ficaram fora dos padrões estabelecidos por essas normas, situando-se aquém dos valores recomendados. Na prática, isto implica que as águas podem sofrer alteração de sabor e que podem ocorrer problemas de corrosão nas tubulações do sistema de distribuição de água.

Dentre as amostras analisadas, os usos das águas que se destacam são: abastecimento doméstico e/ou consumo humano, atividades industriais (resfriamento de máquinas), irrigação e criação de animais (codornas). A seguir serão comentados os teores excessivos dos compostos e elementos químicos em função destes usos.

\section{- Nitrato}

Os compostos nitrogenados são muito solúveis e portanto dificilmente se precipitam. A maioria deles passa para nitrato em meio oxidante e este pode passar para $\mathrm{N}_{2} \mathrm{Ou} \mathrm{NH}_{4}^{+}$em mejos redutores, embora o nitrato tenha a tendência de ser estável. Normalmente as concentrações nas águas subterrâneas estão entre 0,1 e $10 \mathrm{ppm}$, porém em águas poluídas pode chegar a $200 \mathrm{ppm}$ e, em alguns casos, até 1000 ppm. Concentrações elevadas em água destinada a consumo humano podem produzir cianose (conhecida como doença do "bebe azul") em crianças e doenças carcinogênicas, além de conferir corrosividade à agua e produzir interferências em processos de fermentação (CUSTODIO \& LLAMAS, 1996). Normalmente a contaminação das águas subterrâneas por nitrato está relacionada a fossas e a problemas de construção e/ou conservação dos poços. 
Tabela 9 - Legislação e regulamentaçäo dos valores máximos permitidos para consumo humano e outros fins.

\begin{tabular}{|c|c|c|c|c|}
\hline \multirow{3}{*}{$\begin{array}{l}\text { Padrões de } \\
\text { Potabillidade } \\
\end{array}$} & \multicolumn{2}{|c|}{ Resolução CONAMA } & \multirow{3}{*}{$\begin{array}{l}\text { Portaria 36 Ministério } \\
\text { da Saúde 19/01/30 }\end{array}$} & \multirow{3}{*}{$\begin{array}{c}\frac{\text { Organizaçäo Mundial da Saúde }}{\text { OMS }} \\
\text { Recomendado }\end{array}$} \\
\hline & \multicolumn{2}{|c|}{$n^{\circ} 20$ de $18 / 06 / 86$} & & \\
\hline & Classe 2 & Classe 3 & & \\
\hline \multicolumn{5}{|c|}{ Parámetros Fisico-Quimicos } \\
\hline $\mathrm{pH}$ & $6-9$ & $6-9$ & $6,5-8,5$ & $6,5-8,5$ \\
\hline \multicolumn{5}{|c|}{ Parâmetros Quimicos (em mg. $\mathrm{L}^{-1}$ ) } \\
\hline Sulfatos & 250 & 250 & 400 & 400 \\
\hline Fosfatos & 0,025 & 0,025 & & \\
\hline Cloretos & 250 & 250 & 250 & 250 \\
\hline Fuoreto & 1,4 & 1,4 & $0,6-1,7$ & 1,5 \\
\hline Nitrato & 10 & 10 & 10 & 10 \\
\hline Nitrito & 1,0 & 1,0 & & \\
\hline Sódio & & & & 200 \\
\hline Manganés & 0,1 & 0,5 & 0,1 & 0,1 \\
\hline Aluminio & 0,1 & 0,1 & 0,2 & 0,2 \\
\hline Prata & 0,01 & 0,05 & 0,05 & \\
\hline Bário & 1,0 & 1,0 & 1,0 & \\
\hline Cádmio & 0,001 & 0,001 & 0,005 & 0,005 \\
\hline Cobre & 0,02 & 0,5 & 1,0 & 1,0 \\
\hline Chumbo & 0,03 & 0,05 & 0,05 & 0,05 \\
\hline Niquel & 0,025 & 0,025 & & \\
\hline Zinco & 0,18 & 5,0 & 5,0 & $\bar{j}, \hat{v}$ \\
\hline $\mathrm{Fe}_{\text {tora }}$ & & & 0,3 & 0,3 \\
\hline $\mathrm{Cr}_{\text {iotal }}$ & & & 0,05 & 0,05 \\
\hline
\end{tabular}

Classe 1: destinadas ao abastecimento doméstico (sem tratamento prévio)

Classe 2: destinadas ao abastecimento doméstico após tratamento convencional. Irrigaçăo e Recreação.

Classe 3: destinadas ao abastecimento dornéstico após tratamento convencional. Preservaçăo de peixes e outros elementos da fauna e flora. 


\section{- abastecimento doméstico e/ou consumo humano}

Somam 8 (oito) as amostras que apresentaram teores impróprios de nitrato para este fim: 22, 63(1), 63(2), 67(1), 67(2), 67(3), 85(2), 95. A maioria delas pertence a 3 (três) chácaras (Chácara do Paulo - amostra 22, Chácara Morita - amostras 63(1) e 63(2) e Chácara Sol - amostras 67(1), 67(2) e 67(3)), e as outras duas são provenientes da Fábrica de Blocos do Edson - amostra 85(2) e da recicladora de sucatas Rodoplast - amostra (95). Os teores de nitrato nestas amostras variaram entre 10,64 a $75,78 \mathrm{mg} \cdot \mathrm{L}^{-1}$.

No caso das chácaras, suspeita-se que o nitrato das águas seja proveniente de fossas sépticas e/ou de produtos químicos agrícolas (fertilizantes nitrogenados), pois estas constituem as fontes mais comuns de contaminação das águas subterrâneas neste tipo de propriedade. Embora não se disponha de informações sobre a existência e localização de fossas nestas chácaras, acredita-se que elas existam, uma vez que normalmente os estabelecimentos não servidos pela rede de água da SABESP também não o são pela rede de esgoto, e que devam se situar em locais em que o fluxo subterrâneo siga na direção dos poços contaminados. Quanto aos fertilizantes agrícolas, também é desconhecido o seu uso, contudo o proprietário da Chácara Sol revelou o uso de pesticida, embora muito raramente. Deve-se ressaltar que a água do poço 63(1) só apresentou teor impróprio de nitrato na amostra coletada na $2^{\text {a }}$ fase, o que pode ser devido a menor infiltração de água no periodo da coleta, comparado com a $1^{\text {a }}$ fase, permitindo uma maior influência de uma suposta pluma de contaminação nas águas do poço (HIRATA, 2000).

No caso dos poços $85(2)$ e 95 , a principal fonte de contaminação por nitrato parece estar relacionada com os aspectos de preservação dos poços. Evidências a favor são a falta de muro de proteção no poço $85(2)$ e as tampas inadequadas feitas de pedaços de madeira, neste poço, e de pedaços de telha no poço 95 (Figura 54). Também não se descarta a possibilidade de contaminação através de fossas, se elas existirem, e se estiverem à montante do poço com relação ao fluxo subterrâneo.

A utilização das águas nestes estabelecimentos deve ser vista com cautela, pois além do nitrato causa problemas de corrosividade nas tubulações por onde circulam as águas, representa uma séria ameaça à saúde humana. 


\section{- irrigação}

Dentre as amostras analisadas, 4 (quatro) apresentaram teores elevados de nitrato para águas destinadas à irrigação, cujos valores variaram de 18,54 a 37,05 mg. - $^{-1}$, quando o valor máximo permitido é de $10 \mathrm{mg} \cdot \mathrm{L}^{-1}$. Três amostras são provenientes dos poços cacimbas da Chácara Sol - amostras 67(1), 67(2) e 67(3) e uma de fonte da Chácara Morita - amostra $63(4)$.

O maior teor de nitrato foi o da última amostra, cuja água é destinada à hidroponia. As fontes contaminantes, neste caso, devem ser do mesmo tipo daquelas que contaminaram as duas amostras dos poços dessa chácara e das três amostras da Chácara Sol, apontadas no item anterior.

\section{- criação de animais (codornas)}

A amostra 71(1) da Granja de Codorna Nakamura foi a única amostra de água analisada procedente de um poço cacimba cuja água é utilizada para a atividade de criação de codornas, dentre outros usos. O teor de nitrato nesta amostra foi de $23,67 \mathrm{mg} \cdot \mathrm{L}^{-1}$, na $1^{\text {a }}$ fase de coleta, e da ordem de $38 \mathrm{mg} \cdot \mathrm{L}^{-1}$ na $2^{\text {a }}$ fase, valores bem acima do máximo permitido para este uso (10 $\left.\mathrm{mg}^{\mathrm{L}} \mathrm{L}^{-1}\right)$.

No caso desta amostra, suspeita-se que a fonte primária de nitrato nas águas do poço seja por decomposição da matéria orgânica proveniente dos excrementos das aves.

\section{- outras finalidades}

Além das amostras citadas anteriormente, as amostras 25(1), 31(1) e 85(1) também apresentaram teores excessivos de nitrato, porém em função do uso para o qual são destinadas, as concentrações de nitrato pouco interferem.

Dentre todas as amostras analisadas, a amostra 25(1) proveniente da fábrica de rodas esportivas Girus Racing, foi a que apresentou a maior concentração de nitrato, ou seja, $141,64 \mathrm{mg} \cdot \mathrm{L}^{-1}$. A água do poço é destinada a uso geral e às atividades industriais e não para consumo humano. O nivel estático medido no dia da coleta estava a 1,66 metros da superfície e, segundo informações de um funcionário da fábrica, quando chove é muito comum o alagamento dos pátios da empresa com a elevação do nível d'água aflorando no 
gramado e nos vãos do calçamento. Segundo informação do mesmo funcionário, o esgoto passa pelos fundos da fábrica e segue em direção ao rio Jacu no qual é lançado, aparentemente não tendo nenhuma influência sobre o poço que locallza-se bem na frente da fábrica, porém como a fábrica está assentada em terreno plano, em área de terraço, e supondo-se que o fluxo subterrâneo local seja no sentido do rio para o poço (Figura 59), é possivel que haja influência das águas do rio na qualidade das águas deste poço. Além disso o proprietário da Chácara Nakasone (ponto 58 - Figura 40) informou que o Clube dos Securitários (ponto 16 - Figura 40) e a empresa Álcool Ferreira (ponto 56 - Figura 40) lançam residuos num dos tributários do rio Jacu que, segundo ele, encontra-se poluído.

Outro aspecto relevante é a má conservação do poço em termos de limpeza, pois nos dias em que foi visitado, havia vegetação brotando nas paredes internas do poço, o que também pode estar contribuindo para a existência de matéria orgânica na água, que na ocasião da coleta, tinha uma espécie de nata em sua superfície.

As amostras dos poços 31(1) e 85(1) apresentaram concentrações de nitrato de 28,39 e $12,61 \mathrm{mg} . \mathrm{L}^{-1}$, respectivamente. A primeira é procedente da Metalúrgica Gimenez que fabrica artefatos para calçados e utiliza a água do poço para as atividades industriais, e a segunda, provém da Fábrica de Blocos do Edson que usa a água desse poço apenas para molhar os blocos que fabricam. Nesta última, o teor de nitrato só foi excessivo na amostra coletada na $1^{\text {a }}$ fase, o que pode estar relacionado com o regime de chuva um pouco menor neste período, comparado com o da época da segunda amostragem.

Em ambos os poços a fonte de nitrato é atribuida a substâncias orgânicas que eventualmente ingressam para o interior dos poços, pois devido serem tampados apenas com pedaços de madeira ficam quase sempre semi-abertos. No caso do poço $85(1)$, ao redor dele foram observadas muitas folhas caidas que podem facilmente ingressar no poço, já que ele não possui muro de proteção.

Os efeitos prejudiciais do nitrato nestes casos estão relacionados ao poder corrosivo dessas águas, principalmente se utilizadas em maquinários (poços 25(1) e 31(1)).

\section{- Ferro}

A concentração de ferro ferroso nas águas subterrâneas normalmente se situa entre 0 e $10 \mathrm{ppm}$, contudo acima de 0,5 ppm é em geral nociva e incômoda, pois o ferro causa manchas de ferrugem e prejudica a qualidade das águas industriais. Acima de 5 ppm pode 
ser tóxico para as plantas (CUSTODIO \& LLAMAS, 1996). Quando as concentrações excedem alguns miligramas por litro pode-se detectar na água sabores metálicos, medicinais e adstringente (DAEE, 1975).

\section{- abastecimento doméstico/consumo humano}

São 3 (três) as amostras com teores de ferro acima do limite máximo permitido $(0,3$ $\left.\mathrm{mg} \cdot \mathrm{L}^{-1}\right)$, cujos valores variam entre 0,51 e $1,16 \mathrm{mg} \cdot \mathrm{L}^{-1}$ : amostra $31(2)$ da Metalúrgica Gimenez, amostra 88(2) da Lajes e Blocos Tupã e a amostra 95 da recicladora de sucatas Rodoplast.

Em geral o ferro ocorre em pequenas concentrações nas águas subterrâneas de rochas cristalinas, com exceção das provenientes de anfibolito dependendo da acidez da água (SZIKSZAY, 1993). No caso da amostra 95 que apresentou o maior teor (1,16 mg.L-1), acredita-se que a fonte principal de ferro seja a rocha metabásica (anfibolito) que ocorre nas proximidades do poço. Já no caso das amostras 31(2) e 88(2), como os teores de ferro são mais baixos, presume-se que tenha havido contribuição de partículas em suspensão, pois as amostras não foram filtradas antes da coleta.

\section{- atividades industriais (resfriamento de máquinas)}

Para este tipo de atividade somente a amostra $87(1)$, proveniente da Recauchutadora de Pneus Dinâmica, apresentou concentração excessiva de ferro $\left(16,48 \mathrm{mg} \cdot \mathrm{L}^{-1}\right)$ quando comparada com a norma da EPA (1972 apud SZIKSZAY, 1993), que estabelece o limite de $0,5 \mathrm{mg} \cdot \mathrm{L}^{-1}$.

Segundo o relatório da PREFEITURA DO MUNICÍPIO DE SÃO PAULO SECRETARIA MUNICIPAL. DO VERDE E DO MEIO AMBIENTE (1996), o proprietário da recauchutadora comentou que a concentração excessiva de ferro na água do poço, já observada anteriormente, é devida à disposição no passado de grande quantidade de areia de fundição na área onde está instalada a Ranchonete do Gaúcho (ponto 89 - Figura 40). Esta explicação parece razoável, se for confirmado que o fluxo subterrâneo local é de montante para jusante do ponto 89 ao 87. 


\section{- outras finalidades}

Dentre as amostras analisadas com teores excessivos de ferro que não se enquadram nos usos anteriores $(40,63(4), 85(1)$ e $88(1))$, destaca-se a amostra 40 do poço tubular da Metalúrgica Vulcão, cuja concentração é de $2,07 \mathrm{mg} \cdot \mathrm{L}^{-1}$. A origem do ferro nesta amostra está relacionada a problemas de ferrugem na tubulação do poço, que segundo um funcionário da empresa, já teve que ser trocada diversas vezes por este motivo.

\section{- Manganês}

A concentração de manganês na água subterrânea é em geral inferior a 0,2 ppm e raramente ultrapassa $1,0 \mathrm{ppm}$, sendo mais abundante em águas ácidas. O manganês ao oxidar-se forma manchas negras e favorece o crescimento de certas bactérias (CUSTODIO \& LLAMAS, 1996).

\section{- abastecimento doméstico/consumo humano}

Os teores de manganês encontrados mostraram-se pouco excessivos, variando de 0,13 a $0,38 \mathrm{mg} \cdot \mathrm{L}^{-1}$ nas amostras $22,63(2), 67(2), 67(3)$ e $91(1)$, quándo o valor máximo permitido é de $0,1 \mathrm{mg} \cdot \mathrm{L}^{-1}$. No caso do ponto $91(1)$ - Metalúrgica $B T$, verificou-se teor impróprio, de $0,18 \mathrm{mg} \cdot \mathrm{L}^{-1}$, apenas na amostra coletada na $1^{\text {a }}$ fase.

\section{- irrigação}

As amostras 63(4), 67(2) e 67(3) provenientes da Chácara Morita e Chácara Sol indicaram concentração de manganês muito próximas do valor máximo permitido para irrigação $\left(0,1 \mathrm{mg} \cdot \mathrm{L}^{-1}\right)$, porém excedentes, variando de 0,13 a $0,17 \mathrm{mg} \cdot \mathrm{L}^{-1}$.

\section{- outras finalidades}

Dentre estas merecem destaque as amostras $25(1)$ da fábrica de rodas esportivas Girus Racing e 88(1) da Lajes e Blocos Tupã por conteúdos excessivos de manganês, de 1,49 e 0,92 , respectivamente. 
O manganês destas 8 (oito) amostras provavelmente é proveniente de partículas em suspensão, assim como o ferro, uma vez que as amostras rião foram filtradas, principalmente as dos poços $25(1)$ e $88(1)$, pois possuiam aspecto sujo devido à má conservação dos poços.

\section{- Alumínio}

O aluminio apresenta certa resistência à remoção pelas soluções durante o intemperismo, ficando quase sempre retido no solo e formando os minerais de argila. Só existe em quantidades importantes como $\mathrm{Al}^{3+}$ em águas ácidas ou como $\mathrm{Al}_{2} \mathrm{O}_{4}{ }^{2-}$ ou $\mathrm{Al}_{2} \mathrm{O}_{4} \mathrm{H}^{-}$ em águas básicas. A concentração de alumínio nas águas subterrâneas em geral está entre 0,005 e $0,3 \mathrm{ppm}$, podendo chegar muito extraordinariamente a $100 \mathrm{ppm}$ em águas muito ácidas. Não apresenta problemas especificos de nocividade e toxicidade (CUSTODIO \& LLAMAS, 1996).

De acordo com os limites máximos permitidos para consumo humano e irrigação $(0,2$ e $0,1 \mathrm{mg} \cdot \mathrm{L}^{-1}$, respectivamente), muitas amostras apresentam elevadas concentrações desse metal, porém todas estão abaixo do limite de deteç̧ão do método $(0,55 \mathrm{mg}$.L.1.1), com exceção da amostra 22 da Chácara do Paulo, cujo teor é de 1,21 mg.L."1, inviabilizando qualquer comparação dos resultados. O mesmo ocorre para as águas utilizadas para irrigação, representadas pelas amostras $67(1), 67(2)$ e 67(3) da Chácara Sol e pela amostra da fonte da Chácara Morita - 63(4) e, neste caso, a exceção é esta última cujo teor de alumínio é de $0,7 \mathrm{mg} \cdot \mathrm{L}^{-1}$.

Além destas, as amostras 25(1), 85(1), 87(1) e 88(2), também apresentaram concentrações de alumínio acima do limite máximo permitido e do limite de detecção, cujos valores variaram entre 0,69 a $0,98 \mathrm{mg} \cdot \mathrm{L}^{-1}$, porém são destinadas a outros usos.

Acredita-se que os teores elevados de aluminio de todas as amostras analisadas seja decorrente da não filtração, incluindo partículas em suspensão ou que, no caso das amostras $87(1)$ e $88(2)$, estejam relacionados $\mathrm{com}$ as atividades industriais realizadas na recuperadora de alumínio Arpol, localizada à montante destes pontos (ponto 122 - Figura 40 e Tabela 4), pois segundo informação do proprietário da Lajes e Blocos Tupã (ponto 88 . Figura 40), esta recuperadora de alumínio lança seus efluentes no córrego Guaratiba. 


\section{- Fosfato}

A maioria dos fosfatos é pouco solúvel e se precipita como $\mathrm{Ca}_{3}\left(\mathrm{PO}_{4}\right)_{2}$. A presença de cálcio limita seu conteúdo na água e o $\mathrm{CO}_{2}$ dissolvido o favorece. A concentração nas águas subterrâneas está entre 0,001 e 1 ppm, podendo atingir 10 ppm e excepcionalmente 50 . Quando presente em concentrações normais não apresenta nocividade e toxicidade (CUSTODIO \& LLAMAS, 1996). As vezes, os fertilizantes fosfatados podem contaminar as águas subterrâneas enriquecendo-as em fosfato (SZIKSZAY, 1981).

As amostras cujas águas são utilizadas para abastecimento doméstico e/ou consumo humano e que apresentaram teores excessivos de fosfato, segundo as normas da Resolução CONAMA são: 63(1), 63(3), 71(1), 85(2), 91(1), 95. Dentre estas, as amostras $63(1), 71(1)$ e $85(2)$ revelaram teores elevados somente na $2^{\text {a }}$ fase, enquanto para a amostra 91 se deu o contrário. Os valores em geral variaram de 0,03 a $0,08 \mathrm{mg} . \mathrm{L}^{-1}$ e correspondem aos teores das amostras da Chácara Morita 63(1) e 63(3), respectivamente. As águas de onde foram coletadas estas duas amostras são também utifizadas para irrigação, cujo valor máximo permitido também é de $0,025 \mathrm{mg} \cdot \mathrm{L}^{-1}$.

Além destas citammse aquelas destinadas a outros usos, ou seja, atividades industriais (amostra 31(1)), limpeza (amostras 41(1) e 109 - poço tubular) e uso geral, exceto para consumo (amostra 45 - poço tubular). Nestes casos as concentrações variaram de 0,03 a $0,10 \mathrm{mg} \cdot \mathrm{L}^{-1}$.

Visto que no geral as concentrações de fosfato encontradas nas amostras se enquadram, na faixa normal das concentrações nas águas subterrâneas $(0,01$ a 1,0 ppm), não existe riscos de nocividade e toxicidade para os usuários dessas águas, conforme registrado em CUSTODIO \& LLAMAS (1996). Com relação às fontes de fosfato, normalmente são as próprias rochas, que ao serem intemperizadas liberam o fosfato presente nos minerais (ex. apatita). Quanto à contaminação por fertilizantes fosfatados apontada por SZIKSZAY (1981), representa uma possibilidade no caso das amostras 63(1) e 63(3) da Chácara Morita, contudo não se conhece o uso desse tipo de produto nesta propriedade.

\section{- Zinco}

Os minerais de ferro, tais como, os anfibólios e a biotita são os principais portadores de zinco. Como este metal provavelmente é adsorvido pelos sedimentos hidrolizados $e$ 
solos, pequenas quantidades (traços) podem estar presentes nas águas naturais (SZIKSZAY, 1981). O consumo de água contaminada com zinco pode causar atraso físico e mental em bebês e crianças e problemas de rim e aumento da pressão arterial, em adultos (http://www.epa.gov/OGWDW/wot/appa.html - 10/06/99).

Nas águas analisadas foi detectada a presença de zinco em concentrações superiores ao limite máximo permitido $\left(0,18 \mathrm{mg} \cdot \mathrm{L}^{-1}\right)$ para as atividades de abastecimento doméstico, irrigação e recreação, fixados pela RESOLUÇÃO CONAMA - classe 2, nas amostras 45 e 95. Estas amostras são provenientes da Metalúrgica Oriente (poço tubular) e da recicladora de sucatas Rodoplast e suas concentrações de zinco foram de 0,23 e $0,57 \mathrm{mg} \cdot \mathrm{L}^{-1}$, respectivamente. As águas são utilizadas principalmente para abastecimento das empresas, mas também são consumidas na Rodoplast (poço 95).

Nestes casos, é provável que o excesso de zinco nas águas deve estar relacionado a partículas em suspensão, assim como os outros metais analisados (principalmente o ferro, manganês e aluminio) visto que nenhuma amostra foi filtrada. 


\section{6 - DISCUSSÃO DOS RESULTADOS}

\section{Aspectos litoestratigráficos}

A partir do levantamento geológico foram reconhecidas na área de estudo três grupos principais de rocha, ou seja, filitos e xistos, granito-gnaisse e sedimentos quaternários, além da ocorrência local de sedimentos terciários da Bacia de São Paulo. De acordo com os trabalhos regionais, os filitos e xistos pertencem ao Complexo Pilar do Grupo Açungui, porém os trabalhos realizados no Complexo Embu na porção leste do Estado de São Paulo inclui os xistos neste complexo, por isso, neste trabalho, preferiu-se não atribuir estas rochas a nenhum dos complexos, deixando a questão em aberto.

Quanto ao granito-gnaisse, pode até corresponder ao granito fácies Cantareira conforme apontado por JULIANI (1992) como sendo os predominantes na RMSP, porém não correspondem ao tipo granito-gnáissico descrito por IPT (1981b), pois estes possuem caráter porfiróide, diferentemente dos observados na área de estudo. Normalmente esses granitóides geram metamorfismo de contato quando intrudidos em rochas de baixo grau metamórfico, porém não foi possivel observar em campo as relações de contato entre as unidades litológicas PEgo e PEf, bem como entre as outras unidades, devido a existência de poucos afloramentos em face da crescente ocupação territorial.

\section{Aspectos estruturais}

As maiores anisotropias observadas nas rochas através de interpretação de fotografias aéreas foram nas direções N50-70E (no granito-gnaisse) e N40-50 e N60-70 (nos filitos e xistos), que são semelhantes à direção da xistosidade, o que pode estar indicando que muitos lineamentos fotointerpretados no terreno dos xistos e filitos (especialmente os menores traços) como sendo traços de fraturas, podem corresponder a traços de xistosidade. Isto torna-se mais provável quando se compara estas direções com as direções das principais famílias de fraturas obtidas no campo, devido a falta de correspondência entre elas, pois estas últimas possuem direções próximas às dos maiores traços individuais de lineamentos. Por outro lado, esta falta de correspondência tem sido atribuida, neste estudo, principalmente à diferença entre as populações de dados analisadas em fotografia aérea e no campo, além de abrangerem áreas de tamanhos diferentes.

Ao se comparar as direções de maior anisotropia do terreno com as orientações das prováveis fraturas abertas (N60-120) definidas através da aplicação do método de Angelier, 
nota-se que são correlacionáveis, contrariamente ao que se observa entre estas últimas e as principais familias de fraturas obtidas no campo e os maiores lineamentos individuais. Dentre as principais familias de fraturas, três delas ( $3^{\text {as }}$ familias do granito-gnaisse e filitos e xistos e $4^{a}$ família destes últimos) apresentam orientação correspondente às direções das fraturas intermediárias em termos de armazenamento de água, conforme Figura 38 , e as demais estão orientadas segundo as fraturas fechadas, indicando baixo potencial de produção de água.

No geral, as principais familias de fraturas tanto no granito-gnaisse quanto nos filitos e xistos são subverticais (ângulos entre 73 e 87), o que faz com que a probabilidade de interceptação das mesmas por um furo vertical seja pequena. Neste caso, uma situação que poderia aumentar a probabilidade de interceptação das fraturas visando uma maior produção de água é a perfuração através de furos inclinados. No entanto, esta não é uma prática usual na perfuração de poços de água subterrânea, talvez devido às bombas elétricas serem projetadas para trabalhar na posição vertical.

As direções das prováveis fraturas abertas obtidas neste estudo não se correlacionam àquelas indicadas por CEPAS (1994) para a RMSP (Figura 7), orientadas segundo NNW e NNE, que devem ter sido determinadas segundo a direção do esforço máximo compressivo aproximadamente na mesma direção, enquanto neste trabalho, está sendo considerada a direção E-W como a direção de compressão máxima, com base em RICCOMINI (1995) e ASSUMPÇÃO (1998).

Deve-se lembrar, porém, que mesmo para as fraturas com orientações favoráveis ao armazenamento de água é importante se considerar a questão do preenchimento, pois este pode reduzir muito a permeabilidade do aqüifero fraturado, conforme exposto por COSTA \& SIL.VA (1997).

\section{Levantamento do uso e ocupação territorial}

O mapa de uso e ocupação elaborado a partir de fotografias aéreas (IEZZI, 1999) e complementado com as observações de campo revelou que a área de estudo apresenta uma ocupação diversificada e esparsa, porém com predominância dos setores residenciais, comerciais e industriais. A grande diferença observada entre a ocupação da área nos anos de 1996 (fotografias aéreas) e 1999 (levantamento de campo) é com relação às áreas comerciais, que atualmente se concentram mais ao longo das estradas principais (avenida Ragheb Chohfi e estrada do Iguatemi). Os setores industriais e residenciais se localizam 
mais a norte e leste da área, respectivamente. Na estrada do lguatemi, no trecho próximo à Fazenda do Carmo, as atividades comerciais observadas estão relacionadas a ocupações irregulares do terreno, onde se observam fábricas de blocos, depósitos de ferro-velho e desmanche de veículos.

A área Fazenda do Carmo constitui a área onde a ocupação é menos densa em virtude da existência da APA Mata do Iguatemi e também por ser de topografia mais acidentada. Contudo, esta situação está mudando com a implantação dos conjuntos habitacionais da CDHU nas partes norte e sul da APA.

Com relação às atividades de mineração ativas na área de estudo, destacam-se a explotação do granito-gnaisse em pedreiras (Figura 40) para a produção de pedra britada (exceto uma das pedreiras que se encontra desativada) e a explotação do solo argiloso em região de planície (Figura 40) para a fabricação de tijolos, existentes desde a década de 40 conforme relatadas por AZEVEDO (1945).

O cadastramento de fontes potenciais de contaminação da água subterrânea permitiu identificar fontes pontuais na área de estudo correspondentes a lavagem de tambores contendo resíduos de tintas e solventes, disposição irregular de residuos sólidos, postos de serviços e cemitério. Dentre estes, os dois primeiros apresentam uma característica peculiar que é a freqüente mudança de localização, o que, em parte, dificultou o cadastramento dessas fontes na área. Neste cadastramento não foram incluídas as indústrias em função das dificuldades encontradas para a obtenção de dados como tipo de atividade, materiais manuseados e tipo e volume de efluentes produzidos em cada uma delas, além do destino final dos mesmos, por se tratar de dados não confidenciais. Também não foram incluídos os poços desativados, pois seriam necessárias informações sobre os aspectos do poços quanto a existência de tampas e lacres, especialmente os poços tubulares, que quase não foram observados em campo devido a dificuldade de acesso imposto pelas empresas nas
quais se situam.

Quanto a disposição irregular de resíduos sólidos (domésticos e industriais) representariam um perigo maior de contaminação das águas subterrâneas se fossem locais fixos de disposição e em quantidades relativamente maiores que aquelas que foram observadas na área, por isso são mais representativos de problemas ambientais relacionados à superfície, como a poluição e assoreamento dos rios e proliferação de organismos patológicos, que podem colocar em perigo a saúde da população que reside próxima a estes pontos de disposição de resíduos. 


\section{Levantamento hidrogeológico}

Antes de mais nada é necessário esclarecer que os estudos referentes aos aqüiferos da área englobam tanto o aqüifero poroso, representado pelo manto de intemperismo e coberturas alóctones (sedimentos coluvionares e aluvionares) como o aqüifero fraturado propriamente dito (rocha sã fraturada), conforme descritos em COSTA \& SILVA (1997). Neste contexto, foi verificado que a maioria dos poços cadastrados é representada pelos poços cacimbas (pelo menos 87 poços ativos) que explotam água essencialmente do aqüifero poroso (cujas espessuras médias são de 33,25 e 54,67 m no granito-gnaisse e nos filitos e xistos, respectivamente), utilizando-as predominantemente para atividades industriais, comerciais e rurais. Em contrapartida, os poços tubulares (pelo menos 24 poços ativos) explotam água quase exclusivamente do aqüifero fraturado, com exceção do poço 109 , porém as águas são usadas para os mesmos fins que as dos poços cacimbas. A prática de utilização da água subterrânea na área é antiga e tem se intensificado com a implantação das indústrias e estabelecimentos comerciais, que passaram a explotar água do aqüífero fraturado com maior intensidade a partir da década de 90 , com o aumento da perfuração de poços tubulares. A quantidade média de água utilizada por dia considerando um periodo de 12 horas de uso é estimada em $1.975 \mathrm{~L}$ por poço cacimba e em $30.720 \mathrm{~L}$ por poço tubular, sendo a única fonte de abastecimento de água para muitas famílias.

Contudo, os dados de produção dos poços obtidos através de testes de bombeamenio revelaram que o aqüifero fraturado desenvolve vazões relativamente baixas, porém maiores nos poços que são perfurados nos filitos existos (média de $4,65 \mathrm{~m}^{3} / \mathrm{h}$ ), a exemplo dos poços $(38,40,71$ e 119), independente da profundidade dos mesmos. Resultados semelhantes foram encontrados nos filitos e xistos do Grupo São Roque a noroeste da Grande São Paulo, por MENEGASSE (1991), cujas vazões dos poços foram da ordem de $20 \mathrm{~m}^{3} / \mathrm{h}$. Isto não é o que em geral se observa, pois segundo a relação de potencialidade hídrica estabelecida por COSTA \& SILVA (1997), os filitos ocupam o último lugar e os gnaisses o segundo, estando acima até dos micaxistos. Isto é válido também de acordo com a avaliação do potencial hidrogeológico realizada por CEPAS (1994) no aqüifero cristalino da RMSP, onde as rochas granitóides e gnáissicas (unidade PEgo) apresentam melhor potencial de armazenamento de água que os micaxistos, devido ao maior desenvolvimento de estruturas de caráter rúptil, bem como de manto de intemperismo mais permeável em relação às últimas. Tendo em vista que, contrariamente aos dados bibliográficos, esta é a região onde se encontra as maiores produções de água na área, talvez o espesso manto de intemperismo esteja funcionando como um reservatório regulador, a despeito da alta porcentagem de argila na sua composição. 
Uma outra situação favorável ao armazenamento de água apontado pela literatura são os contatos entre diferentes litotipos, porém, na área de estudo, dois poços (30 e 115(1)) que se encontram próximos ao contato entre os filitos e xistos e granito-gnaisse apresentam vazões relativamente baixas entre 1,67 e $2,00 \mathrm{~m}^{3} / \mathrm{h}$, indicando que este controle não exerce grande influência no armazenamento de água na área de estudo.

Com relação aos valores de capacidade específica obtidos $\left(0,005\right.$ a $\left.0,139 \mathrm{~m}^{3} / \mathrm{h} / \mathrm{m}\right)$, nota-se que são extremamente baixos, sendo inferiores aos verificados no aqüifero fraturado da RMSP, por DAEE (1975), com média de $0,34 \mathrm{~m}^{3} / \mathrm{h} / \mathrm{m}$. Porém, para que estes dados sejam utilizados na avaliação da qualidade dos aqüiferos em termos potenciais de produção, seria necessária uma análise dos testes de bombeamento dos poços, aos quais não se teve acesso.

Durante este estudo, também se tentou realizar a correlação entre os dados de vazão e capacidade específica dos poços tubulares e proximidade de lineamentos, a exemplo dos trabalhos de GONÇALVES (1978), MENEGASSE (1991), CELLIGOI (1993), FERNANDES (1997) e KODITUWAKKU (1997), porém, em função dos poucos dados obtidos e da localização imprecisa de alguns poços, a pequena correlação observada não foi considerada como conclusiva.

Com base nas profundidades de entrada de água dos poços foi verificado que as fraturas abertas se encontram no máximo até 192 metros no granito-gnaisse, sendo comparáveis com as principais entradas de água na região de Guarulhos obtidas por DINIZ

Considerando a vazão média dos poços tubulares em geral $\left(4,44 \mathrm{~m}^{3} / \mathrm{h}\right)$ e o número estimado de habitantes (22.085 habitantes) que ocuparão os conjuntos habitacionais da CDHU na área Fazenda do Carmo, verifica-se que para suprir essa população através de água subterrânea, seriam necessários mais de 41 poços em regime de bombeamento de 24 horas, o que torna-se inviável o uso da água subterrânea como fonte principal de abastecimento nesta área.

\section{Análises químicas}

A verificação do erro das análises químicas, através do cálculo do balanço iônico, revelou valores que variaram no geral de 0 a $37,05 \%$, sendo que para a maioria das amostras o valor de erro se situou entre 10 e $20 \%$, o que é considerado elevado. O principal 
motivo disso é atribuído às imprecisões na determinação da alcalinidade (a partir da qual se obteve o ion bicarbonato) que foi efetuada utilizando-se um conta-gotas comum, pois dependendo da posição em que é colocado no momento da dosagem do ácido sulfúrico pode gerar volumes diferentes para cada gota. O fato de maiores porcentagens de amostra $(70 \%)$ entre aquelas cuja alcalinidade foi determinada no campo terem indicado erros situados entre 10 e $30 \%$, comparado com as amostras da $1^{\text {a }}$ fase (alcalinidade em laboratório), mostra a influência das transformações físico-químicas após a amostragem, modificando os parâmetros a serem analisados em laboratório, incluindo o bicarbonato que já estava mais em equilibrio com a composição da amostra quando analisada, no caso das amostras coletadas na $1^{a}$ fase.

Também deve ser lembrado que baixas concentrações iônicas como as das águas analisadas podem gerar valores mais elevados de erro sem que isso represente erros de análise, segundo o que mostraram CUSTODIO \& LLAMAS (1996). Diante desses fatos, conclui-se que os valores de erro obtidos são considerados aceitáveis.

As maiores condutividades elétricas das águas dos poços cacimbas podem ser justificadas pela permeabilidade de poros existente no aqüifero poroso que proporciona um maior contato entre rocha/água e com isso um aporte de sais mais rápido quando comparado com os aqüiferos fraturados (poços tubulares), apesar de nestes últimos existirem condições mais favoráveis à dissolução de sais, como maiores temperaturas e pressões. Como os valores de condutividade elétrica de dois poços tubulares (45 e 109) foi determinada através das concentrações dos íons analisados no laboratório é possivel que as transformações físico-químicas que normalmente se processam após a amostragem tenham afetado a solubilidade de alguns elementos reduzindo suas concentrações nas águas e resultando em condutividades mais baixas.

$\mathrm{O} \mathrm{pH}$ ácido das águas provenientes dos poços cacimbas e as baixas concentrações de bicarbonato predominantes são compatíveis com os das águas de rochas cristalinas em
geral.

As águas analisadas apresentaram ampla variação composicional evidenciada através do diagrama de Piper (Figura 57), de modo que as provenientes do aqüifero poroso foram classificadas predominantemente como sulfatadas cálcicas e bicarbonatadas cálcicas, enquanto as provenientes do aqüifero fraturado foram classificadas predominantemente como bicarbonatadas sódicas. No caso das águas do aqüifero poroso (poços cacimbas) pode-se dizer que, no geral, o cálcio predomina sobre o sódio e potássio e os ânions bicarbonato e nitrato predominam sobre os demais (sendo que, neste caso, o nitrato pode 
estar indicando contaminação das águas), enquanto as águas dos poços tubulares são mais ricas em sódio que em cálcio e muito ricas em bicarbonato, evidenciando uma zonalidade vertical em termos de composição química, segundo o que comentou SZIKSZAY (1993).

A análise da qualidade da água permitiu verificar que de acordo com os usos (abastecimento doméstico e/ou consumo humano, irrigação, atividades industriais e criação de animais) para os quais são destinadas as águas correspondentes aos pontos amostrados algumas águas apresentam restrições quanto ao nitrato, ferro, manganês, alumínio, fosfato e zinco, bem como de $\mathrm{pH}$.

Aquelas que são destinadas ao abastecimento doméstico ou consumo humano apresentam maiores restrições quanto ao nitrato, ferro, manganês e zinco, sendo que este último e o primeiro podem causar graves doenças principalmente em crianças. $O$ ferro e o manganês causam manchas nas roupas, além do ferro afetar o sabor das águas assim como o pH ácido que, por sua vez, podem causar corrosão nas tubulações. Para a irrigação, embora algumas águas tenham apresentado teores elevados de nitrato, manganês e alumínio, não se encontrou na literatura os motivos que levam às restrições para esta atividade. As águas destinadas às atividades industriais, especialmente resfriamento de máquinas (poço 87) apresentaram restrições principalmente com relação ao ferro e ao $\mathrm{pH}$, pois podem causar problemas de ferrugem e corrosão nos equipamentos. Para a atividade de criação de animais, apenas as águas do poço 71(1) - Granja de Codorna Nakamura é que se destinam a esse uso e apresentaram teor excessivo de nitrato atribuido à influência dos excrementos das aves gerados em função da própria atividade.

Dentre as fontes apontadas como possíveis responsáveis pelas elevadas concentrações dos elementos e compostos analisados que se relacionam com as atividades antrópicas desenvolvidas em superficie estão as fossas, uso de produtos químicos agrícolas (nitrogenados e fosfatados), disposição de resíduos sólidos (areia de fundição) e efluentes industriais no solo e/ou nas águas superficiais. Assim, são apontadas duas áreas nas quais podem ter se desenvolvido plumas de contaminação: região próxima à APA Mata do Iguatemi às margens do córrego Guaratiba e rio Jacu nas proximidades do ponto 25 , que poderiam ser investigadas com detalhe em trabalhos futuros.

Quanto aos metais pesados (cromo, niquel, chumbo, cádmio) analisados que poderiam se relacionar com as atividades de lavagem de tambores, nenhum deles foi detectado nas amostras analisadas, o que de forma alguma indica ausência de contaminação por estas atividades, pois este material pode estar presente na zona não saturada não tendo atingido ainda o nível d'água. 


\section{7 - CONCLUSÕES E RECOMENDAÇÕES}

O maciço fraturado sobre o qual foi desenvolvido o estudo é constituído por rochas cristalinas de idade proterozóica, do Grupo Açungui (filitos, xistos e anfibolito) e granitóide intrusivo (granito-gnaisse) inseridas em área de grande complexidade estrutural.

A água subterrânea ocorre no chamado aqüifero cristalino subdividido em: aqüifero poroso formado pelo manto de intemperismo e sedimentos alóctones (sedimentos coluvionares e aluvionares) e o aqüifero fraturado representado pela rocha sã fraturada e desempenha um importante papel no abastecimento de água da área de estudo, constituindo a única fonte de abastecimento de água para muitas familias.

Os objetivos propostos neste trabalho foram avaliar as condições hidrogeológicas do aqüifero cristalino em termos qualitativos, através da caracterização do uso e ocupação da área, principalmente quanto ao potencial poluidor, com a identificação de fontes potenciais de contaminação da água subterrânea, e a proposição de diretrizes de proteção, visando determinar a viabilidade ou não de utilização da água subterrânea na área Fazenda do Carmo, onde estão sendo implantados os conjuntos habitacionais da CDHU. Neste sentido as principais conclusões desta pesquisa são:

1. A área de estudo apresenta uma ocupação diversificada, porém com predominância dos setores residenciais, comerciais e industriais.

2. As rochas com maior potencial de produção de água na área de estudo são os filitos e xistos provavelmente devido ao relativamente espesso manto de intemperismo (cerca de 54 metros), que se acredita funcionar como reservatório de água interligado ao aqüífero fraturado.

3. As famílias de fraturas com maior potencial de armazenamento de água na área de estudo são as orientadas segundo as direções N56W/82SW (no granito-gnaisse) e N35W/86NE e N36W/87SW (nos filitos e xistos), correspondendo a um potencial intermediário de armazenamento de água.

4. As águas subterrâneas apresentam baixas concentrações de ions, em geral, e suas composições químicas variam em profundidade, sendo classificadas predominantemente como sulfatadas cálcicas e bicarbonatadas cálcicas no aqüífero poroso e predominantemente como bicarbonatadas sódicas no aquüifero fraturado. 
5. A área de estudo apresenta um elevado potencial de contaminação das águas subterrâneas em função das atividades antrópicas desenvolvidas como: lavagem de tambores contendo produtos químicos (tintas e solventes), postos de serviços, disposição irregular de resíduos sólidos, cemitério, prováveis fossas, rios poluídos por esgoto e poços mal conservados.

6. O principal problema verificado de contaminação das águas subterrâneas da área, especialmente do aqüifero poroso, está relacionada ao nitrato, cujas fontes de contaminação são atribuídas principalmente a fossas e/ou rios poluídos por esgoto.

7. A qualidade das águas subterrâneas em termos dos parâmetros analisados é em geral considerada adequada em relação aos usos para os quais se destinam, com exceção daquelas com elevados teores de nitrato e zinco, utilizadas para consumo humano, devido às graves doenças que estes podem provocar.

8. Em vista da grande demanda de água requerida para abastecer os futuros moradores das unidades habitacionais da CDHU na área Fazenda do Carmo, conclui-se que a utilização da água subterrânea é viável apenas como uma fonte complementar de abastecimento, devendo ser utilizada com critério em função dos teores anômalos dos compostos e elementos químicos encontrados.

9. Como principais diretrizes de proteção das águas subterrâneas são propostas a instalação de rede de saneamento básico em toda a área, o que certamente contribuirá para a redução e/ou eliminação do nitrato nas águas, e uma fiscalização mais rigorosa de órgãos competentes sobre as atividades industriais e comerciais que geram algum tipo de resíduo, no sentido de não o disporem irregularmente e sim em aterros sanitários. Além disso, se faz necessária uma melhor orientação aos proprietários de poços, referente à importância da boa conservação dos poços para a qualidade das águas subterrâneas.

Para trabalhos futuros na área voltados à prospecção de água subterrânea são recomendados estudos geofísicos, por exemplo, através do método VLF ("Very Low Frequency"), com caminhamentos perpendiculares às prováveis fraturas abertas, ou seja, mais ou menos na direção N-S, para a deteç̧ão das fraturas em subsuperficie e, em seguida, a aplicação de eletrorresistividade pela técnica SEV (Sondagem Elétrica Vertical) nos pontos onde foram localizadas as fraturas, para a determinação da espessura do manto de intemperismo. Neste caso, os locais mais indicados para a perfuração de poços deverão ser aqueles sobre as fraturas e onde o manto de intemperismo é mais espesso. Adicionalmente, não deve ser descartada a possibilidade de execução de poços inclinados, 
com o objetivo de aumentar a probabilidade de cruzar fraturas, já que estas são subverticais.

Também se recomenda que os novos poços a serem perfurados na área explorem tanto o aqüífero poroso como o aqüifero fraturado, principalmente no terreno de ocorrência dos filitos e xistos, a exemplo do poço 109, já que o manto de intemperismo parece funcionar como um reservatório de água interconectado com o aqüifero fraturado, o que também deveria ser investigado em trabalhos futuros.

Quanto à avaliação de contaminação das águas subterrâneas através das fontes apontadas neste estudo são recomendados estudos de detalhe que identifiquem as áreas de influência dessas atividades, levando em conta o fluxo subterrâneo e análises químicas de substâncias orgânicas das águas da zona saturada e não saturada, como por exemplo nas duas áreas onde podem ter se desenvolvido plumas de contaminação, comentadas no capítulo anterior. Nestes casos, as amostras destinadas a análises de metais devem ser filtradas, eliminando a possibilidade de solubilização de partículas em suspensão após a adição do ácido nítrico, que pode dificultar as interpretações das análises. Se necessário a determinação da alcalinidade, que seja feita diretamente no campo, utilizando-se uma pipeta volumétrica em substituição ao conta-gotas, e com a maior rapidez possivel para reduzir ao máximo o contato da amostra com a atmosfera. As análises de potabilidade devem incluir também parâmetros organolépticos e bacteriológicos. 


\section{REFERÊNCIAS BIBLIOGRÁFICAS}

ALMEIDA, F.F.M. (1964) Fundamentos geológicos do relevo paulista. Boletim. Instituto Geológico, v.41, p.167-262.

ANGELIER, J.; MECHLER, P. (1977) Sur une méthode praphique de récherche des contraintes principales également utilisable en téctonique et en séismologie: la méthode des dièdres droits. Bulletin de la Societé Géologique de France, v.19, n.6, p.1.309-18.

ARTHAUD, F. (1969) Méthode de détermination graphique des directions de raccourcissement, dállongement et intermédiaire d'une population de failles. Bulletin de la Societé Géologique de France, v.11, p.729-37.

ASSUMPÇÃO, M. (1998) Sismotectónica y esfuerzos en Brazil. Fisica de la Tierra. Madrid.

AZEVEDO, A.E. (1945) A região de itaquera. In:

São Paulo, p.97-119. (Tese provimento Subúrbios orientais de São Paulo. Universidade de São Paulo.

AZEVEDO, A.A.; ALBUQUERQUE FILHO, J.L. (1998) Águas subterrâneas. In: OLIVEIRA, A. M. S.; BRITO, S.N.A. Geologia de engenharia. São Paulo, ABGE. p.111-130.

BEAR, J. (1972) Dynamics of fluids in porous media. Mineola, NY, Dover. $320 \mathrm{p}$.

BERTACHINI, A.C. (1987) Estudo das características hidrogeológicas dos terrenos cristalinos sob clima úmido na região de Jundiaí, em São Paulo. São Paulo, 110p. (Dissertação-Mestrado) - Instituto de Geociências, Universidade de São Paulo.

CARNEIRO, C.D.R. (1996) Projeção estereográfica para análise de estruturas: programas ESTER E TRADE, fundamentos teóricos, exercícios e aplicações em microcomputador, laboratório e campo. Publicação IPT, n.2377, p.1-158.

CAVALCANTE, I.N. (1990) Estudo hidrogeológico de terreno cristalino com manto de intemperismo - área Piloto de Atibaia. São Paulo, 123p. (Dissertação-Mestrado) Instituto de Geociências, Universidade de São Paulo. 
CDH - COMPANHIA DE DESENVOLVIMENTO HABITACIONAL DO ESTADO DE SÃO PAULO (1987) Programa de assentamento habitacional de 20.000 unidades na RMSP . Projeto Fazenda do Carmo. São Paulo, CDH. 23p.

CELESTINO, T.B. (1986) Determinação de propriedades e parâmetros de maciços rochosos. In: SIMPÓSIO SUL-AMERICANO DE MECÂNICA DE ROCHAS,2., Porto Alegre, 1986. Anais.

CELLIGOI, A. (1993) Recursos hidrícos subterrâneos da Formação Serra Geral em Londrina - PR. São Paulo, 83p. (Dissertação-Mestrado) - Instituto de Geociências, Universidade de São Paulo.

CEPAS - CENTRO DE PESQUISAS DE ÁGUAS SUBTERRÂNEAS (1994) Diagnóstico hidrogeológico da região metropolitana de São Paulo - relatório final. São Paulo, Sabesp/Cepas/IG-USP, 115p.

CETESB - COMPANHIA DE TECNOLOGIA DE SANEAMENTO AMBIENTAL (1987) Guia de coleta e preservação de amostras de água. São Paulo, CETESB. 150 p.

COSTA, W.D.; SILVA, A.B. (1997) Hidrogeologia dos meios anisotrópicos. In: FEITOSA, F.A.C.; MANOEL FILHO, J. (coords.). Hidrogeologia: conceitos e aplicações. Fortaleza, CPRM/LABHID. p.133-163.

COUTINHO, J.M.V. (1972) Petrologia do pré-cambriano de São Paulo e arredores. Boletim IG-USP: Publicação Especial, n.3, p.5-99.

CUSTODIO, E.; LLAMAS, M.R. eds. (1996) Hidrologia subterránea. 2. Ed. Barcelona, Omega. v. 1.

DAEE - DEPARTAMENTO DE ÁGUAS E ENERGIA ELÉTRICA DO ESTADO DE SÃO PAULO (1975) Estudo de águas subterrâneas, região administrativa I - Grande São Paulo. São Paulo, DAEE. v.1, p.1-220.

DINIZ, H.N. (1996) Estudo do potencial hidrogeológico da bacia hidrográfica do Rio Baquirivu-Guaçu, Muricípios de Guarulhos e Arujá, SP. São Paulo, 296p. (TeseDoutorado) - Instituto de Geociências, Universidade de São Paulo. 
EMPLASA - EMPRESA METROPOLITANA DE PLANEJAMENTO DA GRANDE SÃO PAULO (1980) Carta geológica da região metropolitana da Grande São Paulo: escala 1:100. 000. São Paulo, EMPLASA. 2 folhas.

ETCHEBEHERE, M.L.C.; HASUI, Y.; MAGALHÃES, F.S.; FRANGIPANI, A. (1992) Análise estrutural aplicada à prospeç̧ão de fontes termais no planalto de Poços de Caldas (SP/MG). In: HASUI, Y. ; MIOTO, J.A.. Geologia estrutural aplicada. São Paulo, ABGENotorantim. p. 439-459.

FERNANDES, A.J. (1997) Tectônica cenozóica na porção média da bacia do Rio Piracicaba e sua aplicação à hidrogeologia. São Paulo, 236p. (Tese-Doutorado) Instituto de Geociências, Universidade de São Paulo.

FERNANDES, A.J. (1991) As unidades regionais do Complexo Embu e seu embasamento, no leste do Estado de São Paulo. São Paulo, 120p. (Dissertação Mestrado) - Instituto de Geociências, Universidade de São Paulo.

FOSTER, S.; GOMES, D.C. (1989) Monitoreo de la calidad de las aguas subterráneas: uma evaluación de métodos y costos. Centro Panamericano de Ingenieria Sanitaria y Ciencias del Ambiente (CEPIS), Lima, Peru. Organizacion Panamericana de la Salud/Organização Mundial de la Salud/Programa de Salud Ambiental (HPE), 111p.

FOSTER, S.; VENTURA, M.; HIRATA, R.C.A. (1987) Contaminación de las aguas subterráneas: um enfoque ejecutivo de la situación en America Latina y el Caribe en relación con el suministro de agua potable. Lima, CEPIS. 42p.

GIMENEZ-FILHO, A.; MACHADO-JR. D. de L.; ZAINE, J.E.; FRASCÁ, M.H.B. de O. (1991) Geologia das folhas Jacarei, Tremembé, Taubaté e Pindamonhangaba - SP. Parte 2: Embasamento Meridional da Bacia de Taubaté. In: SIMPÓSIO DE GEOLOGIA DO SUDESTE, 2., São Paulo, 1991. Atas., São Paulo, SBG, p. 491-500.

GONÇALVES, R.L.F. (1978) Critérios fotogeológicos para locação de poços em rochas cristalinas de Minas Gerais. In: CONGRESSO BRASILEIRO DE GEOLOGIA, 30., Recife, 1978. Anais. Recife, SBG, v. 6, p. 2934-2942.

HASUI, Y. (1975a) Evolução polifásica do precambriano a oeste da capital paulista. Boletim IG-USP: Publicação Especial, n.6, p.95-107. 
HASUI, Y. (1975b) Geologia da Folha de São Roque. Boletim IG-USP: Publicação Especial, n.6, p.157-183.

HASUI, Y.; CARNEIRO, C.D.R.; BISTRICHI, C.A. (1980) Estruturas e tectônica do précambriano de São Paulo e Paraná. Anais da Academia Brasileira de Ciências, Rio de Janeiro, v. 52, n.1, p. 61-76.

HASUI, Y.; MIOTO, J.A. (1992) Mina de carbonatito de Jacupiranga: permeabilidade do maciço avaliada pelo modelo geoestrutural. In: Paulo. ABGE/ Votorantim. p.383-398. Geologia estrutural aplicada. São

HASUI, Y.; SADOWSKI, G.R. (1976) Evolução geológica do precambriano na região do Estado de São Paulo. Revista Brasileira de Geociências, v.6, n.3, p.182-200.

HENRIKSEN, H. (1995) Relation between topography and well yield in bore-holes in crystalline rocks, Sogn of Fjordane, Norway. Ground Water, v.33, n.4, p.635-643.

HIRATA, R.C.A. (2000) Comunicação pessoal. São Paulo-SP.

IEZZI, P.B.T. (1999) Estudo de contaminação de água subterrânea por agentes antrópicos na região da APA de Iguatemi. Monografia de Trabalho de Formatura -Instituto de Geociências, Universidade de São Paulo, 33p.

IG - INSTITUTO GEOLÓGICO (1997) Mapeamento da vulnerabilidade e risco de poluição das águas subterrâneas no Estado de São Paulo, IG/CETESB/DAEE, v. 1, 129 p.

IPT - INSTITUTO DE PESQUISAS TECNOLÓGICAS DO ESTADO DE SÃO PAULO (1981a) Mapa geomorfológico do Estado de São Paulo, escala 1:100.000. São Paulo, IPT. 2 v.

IPT - INSTITUTO DE PESQUISAS TECNOLÓGICAS DO ESTADO DE SÃO PAULO (1981b) Mapa geológico do Estado de São Paulo, escala 1:500.000. São Paulo, IPT. $2 v$. 
JULIANI, C. (1992) O embasamento pré-cambriano da Bacia de São Paulo. in: PROBLEMAS GEOLÓGICOS E GEOTECTÔNICOS NA REGIÃO METROPOLITANA DE SÃO PAULO, São Paulo, 1992. Seminário, São Paulo, ABAS/ABGE/SBG, p. 3-20.

JULIANI, C.; BELJAVSKIS, P.; SCHORSCHER, H.D. (1986) Petrogênese do vulcanismo e aspectos metalogenéticos associados: Grupo Serra do Itaberaba na Região do São Roque - SP. In: CONGRESSO BRASILEIRO DE GEOLOGIA, 34., Goiânia, 1986. Anais. Goiânia, SBG. v.2, p.730-743.

KODITUWAKKU, K.A.W. (1997) Extraction and modelling spatial parameters in groundwater potential studies in a hard rock terrain, Sri Lanka. In: MARINOS, P.G.; KOUKIS, G.C.; TSIAMBAOS, G.C.; STOURNARAS, G.C. eds. Engineering Geology and the Environment. Rotterdam, IAEG. p.1303-1306.

LONG, J.C.S.; REMER, J.S.; WILSON, C.R.; WITHERSPOON, P.A. (1982) Porous media equivalents for networks of discontinuous fractures. Water Resources Research, v.18, n.3, p.645-658.

LONG, J.C.S.; WITHERSPOON, P.A. (1985) The relationship of the degree of interconnection to permeability of fractured networks. Journal of Geophysical Research, v.90, n.B4, p.3087-3098.

LOUIS, C. (1974) Rock hydraulics. Springer, Vienna. (Courses and Lectures-International Centre for Mechanical Sciences, 165). p.299-387.

MAGALHÃES, F.S.; MARQUES, J.D.; SERRA Jr., E. (1992) Análise estrutural do maciço rochoso de fundação da barragem de Porto Primavera, rio Paraná (SP/MS). In: HASUI,Y.; MIOTO, J.A.. Geologia estrutural aplicada. São Paulo, ABGE/Notorantim. p.297-311.

MELO, M.S.;PONÇANO, W.L.; MOOK, W.G.; AZEVEDO, A.E.G. (1987) Datações $C^{14} \mathrm{em}$ sedimentos da Grande São Paulo. In: CONGRESSO DA ASSOCIAÇÃO BRASILEIRA DE ESTUDOS DO QUATERNÁRIO, 1, Porto Alegre. Anais. Porto Alegre, ABEQUA, p.427-436.

MENEGASSE, L.N. (1991) Estudo hidrogeológico das rochas metassedimentares do Grupo São Roque a NW da Grande São Paulo - critérios para locação de poços profundos. São Paulo, 104p. (Dissertação-Mestrado) - Instituto de Geociências, Universidade de São Paulo. 
PREFEITURA DO MUNICIPIO DE SÃO PAULO - SECRETARIA MUNICIPAL DO VERDE E DO MEIO AMBIENTE (1996) In: Relatório Técnico da Área Denominada "Passagem Funda". São Paulo, Departamento de Controle da Qualidade Ambiental - Decont 1. p.164.

QUADROS, E.F. (1992) A condutividade hidráulica direcional de maciços rochosos. São Paulo, 490 p. (Tese - Doutorado) - Escola Politécnica, Universidade de São Paulo.

QUADROS, E.F. (1982) Determinação das características do fluxo de água em fraturas de rochas. São Paulo, 236 p. (Dissertação - Mestrado) - Escola Politecnica, Universidade de São Paulo.

REBOUÇAS, A. (1996) O papel das águas subterrâneas, usos, controle e preservação. Caderno Técnico. ABAS. Diagnóstico do Setor de Hidrogeologia. PADCT-MCT, n.3, p.1-46.

REBOUÇAS, A.C. (1994) Fundamentos de gestão de aqüiferos. In: CONGRESO LATINO AMERICANO DE HIDROLOGIA SUBTERRÁNEA, 2., Santiago, 1994. Metodologias de evaluacion de sistemas aquiferos. Santiago-Chile, ALHSUD/CEPAS-IGUSP. v.1, p.123.

REBOUÇAS, A.C. (1992) Condições de uso e proteção das águas subterrâneas da RMSP. In: PROBLEMAS GEOLÓGICOS E GEOTÉCNICOS NA REGIÃO METROPOLITANA DE SÃO PAULO, São Paulo, 1992. Seminário. São Paulo, ABAS/ABGE/SBG, p.77-87.

REBOUÇAS, A.C. (1988) Groundwater in Brazil. Episodes. v.11, n.3, p.209-214.

REBOUÇAS, A.C.; CAVALCANTE, I.N. (1987) Hidrogeology of Crystaline Rocks in Brazil. Groundwater Exploration and Development in Crystaline Basement Aquifers. Harare, Zimbabwe, África. v.1. Series number CSC (89) WMR - 13, Technical Paper 273. p. 103-126.

REBOUÇAS, A.C.; MENEZES, M.A.S. (1988) Groundwater a vital resource in Brazil. In: INTERNATIONAL GEOLOGICAL CONGRESS, 28., Washington, 1988. Abstracts. Washington, International Geological Union of Sciences. v.2, p.680.

RICCOMINI, C. (1995) Tectonismo gerador e deformador dos depósitos sedimentares pós-gondvânicos da porção centro-oriental do Estado de São Paulo e áreas 
vizinhas. São Paulo, 100p. (Tese Livre-Docência) - Instituto de Geociências, Universidade de São Paulo.

RICCOMINI, C. (1989) O rift continental do sudeste do Brasil. São Paulo, 256p. (TeseDoutorado) - Instituto de Geociências, Universidade de São Paulo.

RICCOMINI, C.; COIMBRA, A.M.; TAKIYA, H. (1992) Tectônica e sedimentação na Bacia de São Paulo. In: PROBLEMAS GEOLÓGICOS E GEOTECTÓNICOS NA REGIÃO METROPOLITANA DE SÃO PAULO, São Paulo, 1992. Seminário, São Paulo, ABAS/ABGE/SBG, p.21-45.

ROCHA, M.; FRANCISS, F.O. (1977) Determinação da permeabilidade anisotrópica dos maciços rochosos a partir de amostras integrais. Geotecnia, n.19, p_.

ROSS, J.L.S.; MOROZ, I.C. (1997) Mapa geomorfológico do Estado de São Paulo: escala 1:500.000. São Paulo, FFLCH/USP, IPT, FAPESP. 2v.

SANTORO, E.; ENS, H.H.; NAGATA, N. (1991) Geologia das folhas Jacareí, Tremembé, Taubaté e Pindamonhangaba - SP. Parte 1: Embasamento Setentrional da Bacia de Taubaté. In: SIMPÓSIO DE GEOLOGIA DO SUDESTE, 2., São Paulo, 1991. Atas., São Paulo, SBG, p.481-490.

SANTOS, A.C. (1997) Noções de hidroquimica. In: FEITOSA, F.A.C.; MANOEL FILHO, J. (coords.) Hidrogeologia: conceitos e aplicações. Fortaleza, CPRM/LABHID-UPFE. p.81-108.

SILVA, F.A. (2000) Comunicação pessoal. São Paulo - SP.

SNOW, D.T. (1966) Three - hole pressure tests for anisotropic foundation permeability. Springer, Vienna. v.4, p.298-316.

SOARES, P.C.; FIORI, A.P. (1976) Lógica e sistemática na análise e interpretação de fotografias aéreas em geologia. Notícia Geomorfológica, v.16, n.32, p.71-104.

SOUZA, L.A.P.; SILVA, R.F.; MOMASA, W.S. (1998) Métodos de investigação. In: OLIVEIRA, A.M.S.; BRITO, S.N.A. Geologia de Engenharia. São Paulo, ABGE, p.193. 
SZIKSZAY, M. (1993) Geoquímica das Águas. Boletim IG USP, Série Didática n. 5, 166p.

SZIKSZAY, M. (1981) Hidrogeoquímica das fontes de Águas da Prata, estado de São Paulo: origem, classificação e caracterização. São Paulo, v.1. (Tese Livre-Docência). Instituto de Geociências, Universidade de São Paulo.

THEODOROVICZ, A.; YAMATO, A. A.; VASCONCELOS, C. S. ; SANTARÉM, P. C.; SILVA, L. C. de; SILVA, V. A. da (1991) Caracteristicas lito-estruturais do cinturão de cisalhamento transcorrente São Paulo - região leste da Grande São Paulo. In: SIMPÓSIO DE GEOLOGIA DO SUDESTE, 2., São Paulo, 1991. Atas., São Paulo, SBG, p. 473-480.

UNESCO (1984) Ground water in hard rocks. Paris, UNESCO. (Studies and reports in hydrogeology, 33). 228p. 
ANEXO 1

MEDIDAS ESTRUTURAIS 


\section{MEDIDAS ESTRUTURAIS}

\begin{tabular}{|c|c|c|c|c|c|c|c|c|}
\hline Dia & Aflomamento & Bandamento & Xistosidade & Crenulaçăo & Juntas & Falha & Lineaçðes & Observações \\
\hline & & & & & & & (e) estrias & \\
\hline & & & & & & & (m) mineral & \\
\hline Dia & 1 - próximo io posto & & $345 / 89$ & $146 / 87$ & & & & \\
\hline \multirow[t]{20}{*}{$20 / 01 / 1998$} & 2. campo de futebol (Jo.Marila) & & $318 / 52$ & & $165 / 82$ & $323 / 44$ & $288 / 35(\mathrm{c})$ & \\
\hline & 3 - próximo a falla & & $327 / 72$ & & $183 / 75$ & & & \\
\hline & & & $339 / 76$ & & $220 / 86$ & & & \\
\hline & & & $335 / 70$ & & $169 / 65$ & & & \\
\hline & & & $330 / 66$ & & $336 / 64$ & & & \\
\hline & & & $330 / 76$ & & $74 / 85$ & & & \\
\hline & & & $332 / 72$ & & $68 / 82$ & & & \\
\hline & & & & & $68 / 86$ & & & \\
\hline & & & & & $268 / 77$ & & & \\
\hline & & & & & $342 / 47$ & & & \\
\hline & & & & & $248 / 69$ & & & \\
\hline & & & & & $253 / 86$ & & & \\
\hline & & & & & $34 / 32$ & & & \\
\hline & & & & & $54 / 90$ & & & \\
\hline & & & & & $49 / 90$ & & & \\
\hline & & & & & $74 / 90$ & & & \\
\hline & & & & & $59 / 90$ & & & \\
\hline & & & & & $78 / 59$ & & & \\
\hline & & & & & $22 / 12$ & & & \\
\hline & & & & & $56 / 90$ & & & \\
\hline Dia & & & & & $77 / 82$ & & & \\
\hline \multirow[t]{30}{*}{$15 / 02 / 1998$} & & & & & $66 / 90$ & & & \\
\hline & & & & & $10 / 90^{*}$ & & & *Numa lente quartzosa \\
\hline & & & & & $59 / 90^{*}$ & & & fraturada \\
\hline & & & & & $52 / 90^{*}$ & & & \\
\hline & & & & & $105 / 24^{*}$ & & & \\
\hline & & & & & $228 / 79^{*}$ & & & \\
\hline & 4. a $100 \mathrm{~m}$ do anterior & & $345 / 90$ & & & & & \\
\hline & & & $315 / 72$ & & & & & \\
\hline & 1 - próximo ato posto & & & & $330 / 55$ & & & \\
\hline & & & & & $87 / 81$ & & & \\
\hline & & & & & $120 / 73$ & & & \\
\hline & & & & & $120 / 65$ & & & \\
\hline & 5 - beira da Estrada do Pês- & & $346 / 88$ & & $105 / 78$ & & & \\
\hline & sego & & $170 / 78$ & & $97 / 85$ & & & \\
\hline & & & $170 / 72$ & & $270 / 88$ & & & \\
\hline & & & & & $112 / 56$ & & & \\
\hline & & & & & $108 / 77$ & & & \\
\hline & & & & & $335 / 64$ & & & \\
\hline & & & & & $170 / 80$ & & & \\
\hline & & & & & $280 / 90$ & & & \\
\hline & & & & & $86 / 80$ & & & \\
\hline & & & & & $65 / 73$ & & & \\
\hline & atloramento (talude cam* & $305 / 57$ & & & $305 / 57$ & & & afor. fora da árca \\
\hline & po de futebol). & & & & $261 / 54$ & & $90 / 05$ & lin $=$ cixo de crenulaçăo \\
\hline & direção afloramento 107 & & & & $326 / 74$ & & & mov.sinistral \\
\hline & & & & & $118 / 70$ & & & frat.nitidamente aberta \\
\hline & & & $300 / 55$ & & $300 / 55$ & & & \\
\hline & 6 - afloramento - Estrada da & & $345 / 40$ & & $285 / 85$ & & & \\
\hline & $3^{\circ}$ Divisão & & & & & & & \\
\hline & 7 - afloramento - Estrada do & & & & $00 / 45$ & & & \\
\hline $\mathrm{Dia}$ & lguatemi (ao lado do Drive- & & & & $248 / 51$ & & & \\
\hline \multirow[t]{14}{*}{$13 / 09 / 1998$} & in) & & & & $342 / 50$ & & & \\
\hline & & & & & $240 / 68$ & & & \\
\hline & & & & & $142 / 70$ & & & \\
\hline & & & & & & & & intercalações quartzosas \\
\hline & & & & & & & & $345 / 60$ \\
\hline & 8 - afloramento - Grota na & & & & $315 / 54$ & & $23 / 21$ & lin = eixo de crenulaça \\
\hline & área Estrada do Palanque & & & & $307 / 47$ & & & \\
\hline & & & $331 / 41$ & & $331 / 41$ & & & \\
\hline & & & & & $323 / 85$ & & & \\
\hline & 9 - Pedreira Lajeado I & $170 / 75$ & & & $250 / 90$ & & & frat. medida de longe \\
\hline & & $170 / 85$ & & & $185 / 76$ & & & \\
\hline & & & & & & $272 / 56$ & $250 / 55(\mathrm{c})$ & mov dextral \\
\hline & & & & & $215 / 74$ & & & \\
\hline & & & & & $270 / 48$ & & & \\
\hline Dia & & & & & $275 / 85$ & & & \\
\hline \multirow{7}{*}{$19 / 09 / 1998$} & & & & & $252 / 50$ & & & \\
\hline & & & & & $300 / 69$ & & & frat. com recristalizaçâa \\
\hline & & & & & $285 / 6 !$ & & & \\
\hline & & & & & $00 / 75$ & & & \\
\hline & & & & & $180 / 85$ & & & \\
\hline & & & & & $128 / 87$ & & & \\
\hline & & & & & $155 / 40$ & & & \\
\hline
\end{tabular}




\begin{tabular}{|c|c|c|c|c|c|c|c|}
\hline & 11 - campo de futebol & $335 / 80$ & $335 / 80$ & $122 / 77$ & & & \\
\hline & & & & $134 / 85$ & & & \\
\hline & & & & $71 / 69$ & & & \\
\hline & & $335 / 72$ & & $335 / 72$ & & & \\
\hline & & & & $115 / 80$ & & & \\
\hline & & & & $119 / 75$ & & & \\
\hline & & & & $115 / 75$ & & & \\
\hline Dia & & & & $125 / 90$ & & & \\
\hline \multirow[t]{18}{*}{$26 / 09 / 1998$} & 9- Pedrcira Lajeado & & & & $276 / 76$ & $5 / 15(\mathrm{e})$ & mov.sinistra! (f.inversa?) \\
\hline & 9 - Pedreira Lajcado 1 & & & & $275 / 84$ & $1 / \$ 9(\mathrm{c})$ & mov.sinistral \\
\hline & 9-Pedreira Lajeado I & & & & $275 / 67$ & & mov sinistral \\
\hline & 9- Pedreira Lajeado I & & & $275 / 81$ & & & \\
\hline & & & & $165 / 42$ & & & \\
\hline & & & & $165 / 21$ & & & \\
\hline & & & & $195 / 30$ & & & \\
\hline & & & & $290 / 24$ & & & \\
\hline & & & & $100 / 45$ & & & \\
\hline & & & & & & & veio preto: $123 / 90$ \\
\hline & 12 - Pedrcira Lajeado 2 & & & $85 / 84$ & $230 / 62$ & $165 / 42(\mathrm{e})$ & mov.dexiral \\
\hline & direçio afloramento $\mathrm{N} 30 \mathrm{E}$ & & & $90 / 80$ & $215 / 85$ & & falha normal \\
\hline & & & & $78 / 90$ & $75 / 86$ & $165 / 13(\mathrm{c})$ & mov.dextral \\
\hline & & & & $95 / 84$ & & & \\
\hline & & & & & $00 / 90$ & $270 / 13(\mathrm{~m})$ & zona de cis. (dextral?) \\
\hline & 12 - Pedreira Lajeado 2 & & & $150 / 70$ & $94 / 85$ & & cavalgamento \\
\hline & direção afloramento N85E & & & $137 / 74$ & $135 / 70$ & $225 / 07(\mathrm{c})$ & mov.sinistral? \\
\hline & & & & $158 / 34$ & & & \\
\hline Dia & & & & $122 / 79$ & & & \\
\hline \multirow[t]{39}{*}{$07 / 11 / 998$} & 12 - Pedreira Lajeado 2 & & & $215 / 85$ & $140 / 70$ & $50 / 04(\mathrm{e})$ & mov.sinistral \\
\hline & direçto afloramento N4SE & & & $75 / 76$ & $130 / 70$ & $45 / 06(\mathrm{e})$ & mov.dextral \\
\hline & & & & $210 / 86$ & & & \\
\hline & & & & $315 / 73$ & & & \\
\hline & & & & $60 / 90$ & & & zona de cisalhamento \\
\hline & 12 - Pedreira Lajeado 2 & & & $150 / 33$ & $135 / 71$ & $45 / 00(c)$ & mov sinistral \\
\hline & direçto afloramento NS & & & $145 / 21$ & $215 / 85$ & $302 / 06(\mathrm{c})$ & mov.sinistral \\
\hline & & & & $75 / 90$ & $38 / 90$ & $308 / 05(e)$ & mov.sinistral \\
\hline & & & & $95 / 80$ & & & \\
\hline & & & & $150 / 44$ & & & \\
\hline & & & & $90 / 80$ & & & \\
\hline & & & & $245 / 85$ & & & \\
\hline & 13 - afloramento en frente & $00 / 60$ & & & & & bandamento composi- \\
\hline & ao Carrefour Pêssego & & & & & & cional \\
\hline & 14 - Pedreira Lajeado 3 & & & & $78 / 85$ & $348 / 0(\mathrm{~m})$ & mov, dextral \\
\hline & direçio afioramento NS & & & & $95 / 80$ & $12 / 23(\mathrm{e})$ & mov. dextral \\
\hline & & & & & $90 / 80$ & $00 / 18(\mathrm{e})$ & mov. sinistral \\
\hline & 14 - Pedreira Lajeado 3 & & & & $249 / 84$ & $154 / 07(c)$ & mov. sinistral \\
\hline & direçio afloramento 333 & & & & & & \\
\hline & 14- Pedrcira Lajeado 3 & & & & $298 / 85$ & $28 / 10$ & mov. sinistral \\
\hline & direçao afloramento $\mathrm{N} 20$ & & & & $50 / 86$ & $320 / 05(\mathrm{c})$ & mov.sinistral \\
\hline & & & & & $115 / 75$ & $25 / 15(\mathrm{c})$ & \\
\hline & & & & & $127 / 81$ & $37 / 10(\mathrm{c})$ & mov.sinistral \\
\hline & & & & $112 / 65$ & & & \\
\hline & & & & $112 / 25$ & & & \\
\hline & & & & $79 / 79$ & & & \\
\hline & & & & $266 / 90$ & & & \\
\hline & & & & $120 / 86$ & & & \\
\hline & & & & $234 / 90$ & & & \\
\hline & & & & $110 / 82$ & & & \\
\hline & & & & $121 / 81$ & & & \\
\hline & & & & $09 / 35$ & & & \\
\hline & & & & $174 / 79$ & & & \\
\hline & & & & $121 / 64$ & & & \\
\hline & & & & $10 / 54$ & & & \\
\hline & & & & $139 / 70$ & & & \\
\hline & & & & $09 / 87$ & & & \\
\hline & & & & $140 / 71$ & & & \\
\hline & & & & $180 / 78$ & & & \\
\hline Dia & & & & $121 / 65$ & & & \\
\hline \multirow[t]{13}{*}{$14 / 11 / 1998$} & & & & $22 / 78$ & & & \\
\hline & & & & $125 / 75$ & & & \\
\hline & & & & $40 / 82$ & & & \\
\hline & & & & $119 / 70$ & & & \\
\hline & & & & $115 / 68$ & & & \\
\hline & & & & $80 / 84$ & & & \\
\hline & & & & $264 / 90$ & & & \\
\hline & & & & $275 / 85$ & & & \\
\hline & & & & $85 / 84$ & & & \\
\hline & & & & $100 / 60$ & & & \\
\hline & & & & $95 / 59$ & & & \\
\hline & & & & $96 / 80$ & & & \\
\hline & & & & $215 / 75$ & & & \\
\hline
\end{tabular}




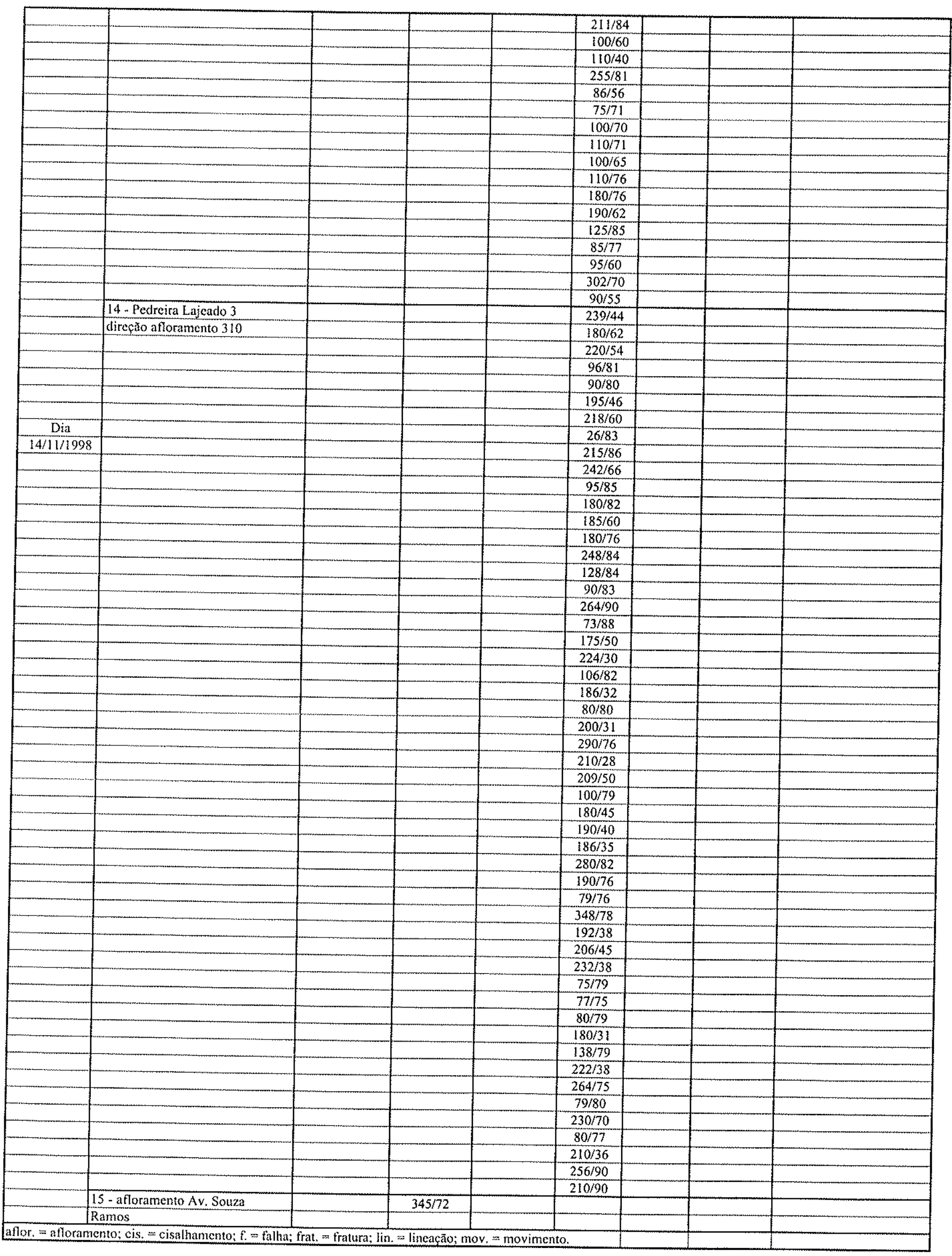


ANEXO 2

ENDEREÇOS DAS EMPRESAS E/OU ESTABELECIMENTOS CADASTRADOS 


\begin{tabular}{|c|c|c|c|c|}
\hline $\mathrm{N}^{0}$ Empresa & Nome da Empresa/Estabelecimento & Endereço & Telefone & Contato \\
\hline 1 & Marmorian - Mármore Sintético do Brasil S/A & R.Agrimensor Sugaya, 391 & $686-0377$ & Décio \\
\hline 2 & Nelpie Indústria Metalúrgica Ltda & R.Matashiro Yamaguishi, 129 & $6521-0844 / 6521-1035 \mathrm{fax}$ & Valdemir/Marcos \\
\hline 3 & Dalver Ind. e Com. de Artefatos de Metal Ltda & R.Matashiro Yamaguishi, 267 & $686-3937 / 686-4236 / 686-1019$ & \\
\hline 4 & Brinquedos Cardoso & R.Matashiro Yamaguishi, $278 / 390$ & $6521-3322$ & Silvio \\
\hline 5 & Planam & R.Zenichi Sato, 21 & $6521-0507$ & Orlando \\
\hline 6 & Tecnotubo S/A - Indústria de Peças Tubulares & R.loneji Matsubayashi, 1221 & $6944-6844 / 686-0089$ & Silas Rodrigues \\
\hline 7 & Furatec - Perfuração de Chapas Ind. e Com. Ltda & R.loneji Matsubayashi, 112 & $6944-5742 / 6944-5846 \mathrm{fax}$ & \\
\hline 8 & Tecnofuro Ind. e Com. Ltda & IR.loneji Matsubayashi, 98 & $686-1699 / 6944-4130 / 6944-9682 \mathrm{fax}$ & \\
\hline 9 & Orfanato Casa do Cristo Redentor & R.Agrimensor Sugaya, 986 & $6521-6211 / 6217 / 6222$ & Oliver \\
\hline 10 & Apolo - Indústria de Brinquedos & R.Zenichi Sato, 341 & & \\
\hline 11 & Chácara CDR & R.Prof.Hasegawa, 1613 & $6101-2052 / 271-4898$ & Fernandes/Maria/Estevăo \\
\hline 12 & Associação Pró-Excepcionais KODOMO-NO-SONO & R.Prof.Hasegawa, 1198 & $6521-6437$ & Pedro Lousano \\
\hline 13 & Ipanema Comavi Raçốes Ltda-Distribuidora & R.Prof.Hasegawa, 185 & 6944-6000/6944-0074 fax & Leonildo Matiussi \\
\hline 14 & Panorama - Fundição de Metais Ltda & R.Prof.Hasegawa, $1128 / 1350$ & $6521-0020$ & Ailton/Silmara \\
\hline 15 & Incase Ind. Mecânica de Equipamentos Ltda & R.Prof.Hasegawa, 499 & $6521-5011 / 6521-9426$ & José Nori/Edna \\
\hline 16 & Clube dos Securitários & R.lonejl Matsubayashi, 982 & $6944-3341 / 686-0112$ & Ricardo/Jorge \\
\hline 17 & Sítio Santo Antônio & R.Prof.Hasegawa, 884 & & Luiz Mateus \\
\hline 18 & Lousano Ind. de Condutores Elétricos Ltda & R.Ioneji Matsubayashi, 352 & 6521-5499 R.256/R.275 & Raimundo/Norma \\
\hline 19 & Obras Sociais Carlos Brunetti & R.Hirovo Kaminobo, 1061 & $205-6086$ & \\
\hline 20 & Maqstyro - Ind. e Com. de Plásticos Ltda & R.Agrimensor Sugaya, 804 & $6944-4409 / 6944-4421 \mathrm{fax}$ & Flávia Cássia/Luiz \\
\hline 21 & Plast Seven Indústria de Plásticos Ltda & R.Agrimensor Sugaya, 1608 & $686-0333$ & \\
\hline 22 & Chácara do Paulo & R.Agrimensor Sugaya, 1637 & $6521-1161$ & Paulo \\
\hline 23 & Bodoque - Ind. de Artefatos de Madeira & R.Prof.Hasegawa, 171 & 6944-8393 & Nazaré \\
\hline 24 & Proteija Ind. e Com. de Produtos Alimentícios Ltda & R.Prof.Hasegawa, 808 & $6521-8669$ & Getúlio/Marco Aurélio \\
\hline 25 & Girus Industrial Ltda - Rodas Esportivas & R.Masato Misawa, 12 & $205-5036$ R.215 & Josimar \\
\hline 26 & Nic - Clube & R.Masato Misawa, 200 & $6521-9460$ & José \\
\hline 27 & RR Etiquetas & R.Masato Misawa, 430 & 6944-1000 R.214 & Claudinei \\
\hline 28 & Schincariol & R.Masato Misawa, 440 & $205-7274$ & \\
\hline 29 & Pavimentadora e Construtora São Luiz S/A & R.Jaime Ribeiro Wright, 967 & $6944-1788$ & \\
\hline 30 & Concretex & R.Jaime Ribeiro Wright, 1225 & $522-8033 / 936-6296$ celular & Guará/Josenildo \\
\hline 31 & Gimenez - Artefatos para Calçados Ltda & R.Chubei Takagashi, 550 & $6521-7279$ & Nélson/Antônio Gimenez \\
\hline 32 & Imbrabor - Fábrica de Borracha & R.Hirovo Kaminobo, 1422 & $205-9433$ & Júlio \\
\hline 33 & Construtora Conterplan & R. Hirovo Kaminobo, 2400 & 6944-2399 & \\
\hline 34 & Forusi - Material Sanitário & R. Guichi Yoshioka, 50 & $6944-9623$ & Arlete \\
\hline 35 & Posto Salemco - Posto Pêssego & Av.Jacu-Pêssego, 2681 & $6944-7712$ & Rinaldo/Sérgio \\
\hline 36 & Gazarra S/A - Indústria Metalúrgica & Av.Jacu-Pêssego, 2630 & $205-8955$ & \\
\hline 37 & Rinaldi Equipamentos Industriais Ltda & R.Kera Nakamura, 1000 & $686-0144$ & \\
\hline 38 & Frelimco Engenharia Ltda - Concreto & R.Zituo Karasawa, 42 & $6944-4857$ & Adilson \\
\hline 39 & Fábrica de Blocos & R.Inácio Monteiro & & \\
\hline 40 & Vulcão S/A - Indústria Metalúrgica e Plástica & Av.Ragheb Chohfi, 4978 & $6731-3699$ R.252 & Claudemir \\
\hline 41 & Auto Capas Abrigo Jacaré Ind. e Com. Ltda & Estrada dos Cunha, $60-\mathrm{A}$ & $682-0500$ & Maria/Jacaré \\
\hline 42 & Resifer - Indústria de Resina & Av.Souza Ramos, 601 & $682-0488$ & Aparecido \\
\hline 43 & Posto - Caminho do Mar & Estrada do lguatemi, 7850 & & \\
\hline 44 & Metalúrgica MF Ind. e Com. Ltda & Av.Souza Ramos, 437 & $6282-0066$ & Marcos \\
\hline 45 & Metalúrgica Oriente S/A - Metais Sanitários & Av.Jacu-Pêssego, 3787 & 205-0088 & Latorre \\
\hline 46 & Notável - Indústria Metalúrgica & Av.Minas do Rio Verde, 740 & $6110-0194$ & Vasco \\
\hline 47 & Perpalind. e Com. de Metais Ltda & Av.Jacu-Pêssego, 701 & $6944-6011 / 205-6016$ & \\
\hline
\end{tabular}




\begin{tabular}{|c|c|c|c|c|}
\hline 48 & Fábrica de Blocos Barbosa & Av.Ragheb Chohfi, 6780 & & Sandra \\
\hline 49 & Fábrica de Blocos Mato Grosso & Av.Ragheb Chohfi, 5940 & $6962-9497$ & João Ferreira/Durvalina \\
\hline 50 & Expresso Urbano São Judas Tadeu & Av.Ragheb Chohfi, 6300 & $6115-1100$ & Airton \\
\hline 51 & Fábrica de Blocos & Av.Ragheb Chohfi, 7450 & & \\
\hline 52 & Depósito de Materiais Farol & Av.Ragheb Chohfi, 7613 & & Irene \\
\hline 54 & Plaza - Ind. e Com. de Móveis & R.Ioneji Matsubayashi, 1323 & $6521-2211$ & Ëlzio \\
\hline 55 & Centro de Treinamentos de Excepcionais A.P.A.C.R. & R.Ioneji Matsubayashi, 1324 & $6521-6976$ & Nolima \\
\hline 56 & Alcool Ferreira S/A & R.Ionei Matsubayashi, 1034 & & Luiz Gonzaga \\
\hline 57 & Boiler Equipamentos Industriais Ltda & R.Keichi Matsumoto, 95 & 6996-0122 & \\
\hline 59 & Chácara Matsumoto & R.Keichi Matsumoto, 446 & & Matsumoto \\
\hline 60 & Centro de Pesquisas de História Natural & R.Jaime Ribeiro Wright, 618 & & \\
\hline 61 & Kossil Com. e Ind. Ltda & R.Jaime Ribeiro Wright, 265 & $6521-6416$ & Nilton \\
\hline 62 & Chácara Estrela & R.Jaime Ribeiro Wright, 405 & $6521-3887$ & Rosa \\
\hline 63 & Chácara Morita & R.Guichi Yoshioka, $303 / 325$ & $6521-8629$ escr $/ 6521-8321$ res. & Jorge Morita \\
\hline 64 & Chácara Arakaki & R.Tomiochi Shimizu, 474 & $6521-1185$ & Gilberto Arakaki \\
\hline 65 & NGA - Armazéns Gerais & R.Hirovo Kaminobo, 451 & $205-4057$ & José Roberto \\
\hline 66 & Granja Kameoka & R.Hisaji Morita, 834 & $6521-7304$ & Kazuo Kameoka \\
\hline 67 & Chácara Sol & R.Jaime Ribeiro Wright, 532 & $6521-3859$ & Patricio/Cristina \\
\hline 70 & Sítio João Owa & R.Zituo Karasawa, 201 & $6521-3717$ & William \\
\hline 71 & Granja de Codorna Nakamura & R.Tineciro Icibaci, 487 & $205-5111$ & Nélson Nakamura \\
\hline 72 & Ema - Indústria de Produtos Quimicos & R.Tineciro lcibaci, 1158 & $6521-9930 / 6521-6648$ & Ariovaldo \\
\hline 73 & INDAB - Indústria Metalúrgica Ltda & R.Go Sugaya, 950 & $205-5144 / 205-5804 / 205-5293$ & Juvenal/Renata \\
\hline 74 & Suljipor - Indústria Metalúrgica Ltda & R.Go Sugaya, 794 & $6944-2362 / 205-8941$ & Sérgio Ricardo \\
\hline 75 & Industrate - Tratamento Termico & R.Go Sugaya, 99 & & \\
\hline 76 & SS Extintores & R.Marieta Lara de Faria, 99 & $6944-5246$ & \\
\hline 77 & Moinho Romariz & Av.Jacu-Pêssego, 2891 & 686-0199 R.216 & Lúcio \\
\hline 78 & Double Fastener Componentes para Fixação Ltda & R.Guichi Shigueta, 02 & $6521-4031 / 3127 / 975-0273 \mathrm{cel}$. & Márcia Buzatto/José \\
\hline 79 & Stil Multi Box - Materiais Elétricos & R.B, 40 & & \\
\hline 80 & Armadilha - Artefatos de Couro & Estrada dos Monos, 244 & & \\
\hline 81 & Grad Spray & R. Guichi Shigueta, 1000 & $69-1488$ & \\
\hline 82 & Arrifana Industrial Import. e Export. de Alimentos Ltda & R.Tineciro lcibaci, 2337 & 6919-2657/6919-0701/6962-9844 & Sônia G. Delben \\
\hline 83 & Pavani Indústria de Cofres Ltda & Estrada do Aricanduva, 127 & 6966-6355/6919-0153 & Valter \\
\hline 84 & Residência & Estrada do Aricanduva, 367 & & Carla \\
\hline 85 & Fábrica de Blocos do Edson & Estrada do Aricanduva, 688 & & Edson \\
\hline 86 & Fábrica de Blocos Casa Nova & Av.Ragheb Chohfi, 5700 & & Lidia/Lina \\
\hline 87 & Recauchutadora de Pneus Dinâmica & Estrada do lquatemi, 600 & $682-0456$ & Manoel \\
\hline 88 & Lajes e Blocos Tupã & Estrada do iguatemi, 666 & $6964-8847$ & Joaquim \\
\hline 91 & Metalúrgica BT & Trav. particular Santo Onório, 100 & $6964-8144$ & José Luiz \\
\hline 92 & Rodoplast - Ind. e Com. de Sucatas Ltda & R.Santa Teresa, 402 & & \\
\hline 93 & Colégio Cristão U.S.A & R.Santa Teresa, 128 & $682-1748$ & Márcia \\
\hline 94 & Metalúrgica Gimenez & R.São Leopoldo, 08 & $6282-0044$ & Elíseo/Sandra \\
\hline 95 & Rodoplast - Ind. e Com. de Sucatas Ltda & R.Sāo Leopoldo, 204 & & Valter \\
\hline 96 & Posto Salemco - Auto Posto Serviço Passagem Funda & Estrada do lguatemi, 2600 & & \\
\hline
\end{tabular}




\begin{tabular}{|c|c|c|c|c|}
\hline 97 & Carbrink Carimbos e Brinquedos Ltda & Av.Souza Ramos, 25 & $682-0633$ & Geraldo \\
\hline 98 & Posto Esso - Posto Arco Verde & R.Inácio Monteiro, 8828 & & \\
\hline 99 & Ind. e Com. Reboque Safari - Indústria Metalúrgica & R. dos Cunha, 08 & & Hadail \\
\hline 100 & Refifica Guaianazes & Av.Ragheb Chohfi, 9800 & $682-0065$ & Máximo \\
\hline 101 & Supermix & Av.Ragheb Chohfi, 7357 & $6962-5770$ & Geraldo \\
\hline 102 & Temper Sul - Têmpera de Aço Ltda & R.Zituo Karasawa, 20 & $996-3236$ & \\
\hline 103 & Consult Com. e ind. Ltda & R.Zituo Karasawa, 40 & $6944-9434$ & \\
\hline 104 & ITA Metal - Indústria de Plástico & R.Kera Nakamura, 501 & $6944-9755$ & Creuza/Santogole \\
\hline 105 & Chácara Tico-Tico & R.Tineciro lcibaci, 130 & $205-9235$ & Laércio \\
\hline 106 & Nova Roclan Fundição Ltda & R.Tineciro lcibaci, 949 & $6521-1391 / 441-3943 / 9987-7455$ cel. & Sebastião/Roberto \\
\hline 108 & Santa Isabel Laminação S/A & R.Prof.Hasegawa, 299 & $6521-8017$ & Juciê \\
\hline 109 & Viação Cidade Tiradentes & Estrada Santo lnácio, 74 & $6282-1122$ & Hélio \\
\hline 110 & Elmar - Produtos Metalúrgicos & R.Luiz Mateus, 2477 & & \\
\hline 111 & Pratêxtil & Estrada do lguatemi, 2613 & $6555-8326$ & \\
\hline 112 & Aluminio & Estrada do lguatemi, 2270 & $9214-8841$ & Antônio \\
\hline 113 & COVEG Construtora & R.Zituo Karasawa & $7295-3233 /(014) 975-3648$ & Eduardo \\
\hline 114 & BEC-MIX & Av.Jacu-Pêssego, 1999-A & $6944-1358 / 6944-6880$ & Elíseo \\
\hline 115 & Carrefour Pêssego & Av.Jacu-Pêssego, 1200 & $6179-1501$ & Adelmo \\
\hline 116 & Eucervi Construtora Ltda & R.Agrimensor Sugaya, 731 & $205-6427 / 205-6541$ & Assis/Ezequias \\
\hline 120 & Empresa Betânia - Comércio de Produtos Químicos & Estrada do lguatemi, 5836 & & \\
\hline 121 & Fábrica de Plásticos São Sebastião & R.Santa Teresa & & \\
\hline 122 & Ind. e Com. Recuperadora de Alumínio Arpol Ltda & R. do Campo & & \\
\hline 123 & Hidraumec Centro Automotivo & Av.Ragheb Chohfi, 7231 & & Nena \\
\hline 124 & Fábrica de Blocos Vargas & Av.Ragheb Chohfi, & & Lina \\
\hline 125 & Iguatemi Posto de Serviços Ltda & Av.Ragheb Chohfi, 4198 & & Agenor \\
\hline 126 & Auto Posto Trevo do Pêssego Ltda & Av.Ragheb Chohfi, & & \\
\hline
\end{tabular}

$\mathrm{Av}_{\mathrm{a}}=$ Avenida; Com. = Comércio; Export. = Exportadora; Import. = Importadora; Ind. = Indústria; $\mathrm{N}_{-}=$Número; Prof. = Professor; R. = Rua; Trav. = Travessa. 
ANEXO 3

PRINCIPAIS CARACTERISTICAS DOS POÇOS E PONTOS D'ÁGUA 


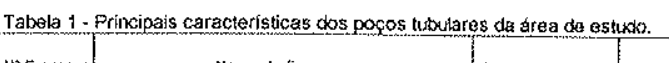

\begin{tabular}{|c|c|c|c|c|c|c|c|c|c|c|c|c|c|c|c|c|c|}
\hline He Emoloser & a Momoda Emorera & 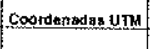 & 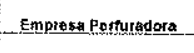 & Ano penturesesoc & 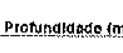 & Othentoromm! & 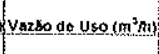 & varso $\left(m^{\prime} m\right)$ & 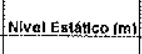 & Nvelo inammeorn & 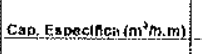 & 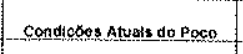 & 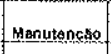 & Proftropo da Rochta $5 \mathrm{~s}$ a $(\mathrm{m})$ & Prot. Bomotea (m) & & \\
\hline 1 & 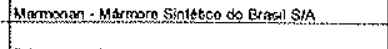 & 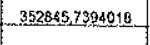 & ravien & 1985 & 870 & & 120 & & & & & omtangaranonetio & Lase. & & & wos offtal. & \\
\hline 4 & 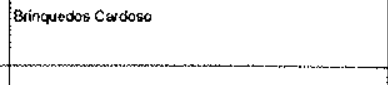 & 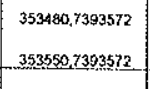 & 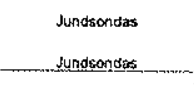 & $\begin{array}{l}1995 \\
1995 \\
\end{array}$ & $\begin{array}{r}230 \\
250 \\
-250\end{array}$ & & & & & & & 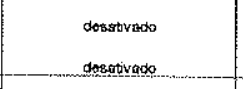 & naco & 17.0 & & & sso osoros secos. \\
\hline$?$ & 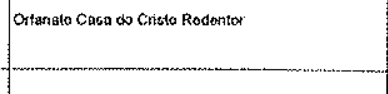 & 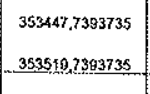 & $\begin{array}{l}\text { Conar } \\
\text { Comer }\end{array}$ & $\begin{array}{l}1974 \\
\quad 1975 \\
\end{array}$ & $\begin{array}{l}235 \\
200 \\
2\end{array}$ & $\begin{array}{l}284 \\
354 \\
3.54\end{array}$ & & $\begin{array}{r}470 \\
-4.90 \\
-90\end{array}$ & $\begin{array}{l}4.00 \\
2.00 \\
\end{array}$ & $\begin{array}{r}147.00 \\
0.2000 \\
\end{array}$ & 0.032 & 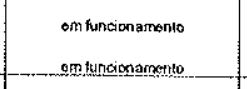 & & $\begin{aligned} 21.02 \\
200202\end{aligned}$ & & & \\
\hline-10 & 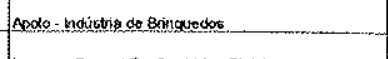 & 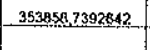 & 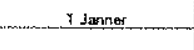 & 1982 & -128 & & -1.04 & & $\log _{2}$ & 20007 & & 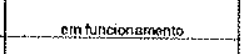 & sm & . & & & \\
\hline$\frac{13}{15}$ & 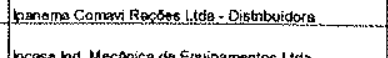 & 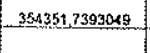 & 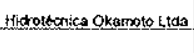 & & $\infty$ & & & & & & & 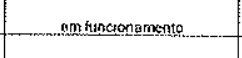 & $\sin$ & & & 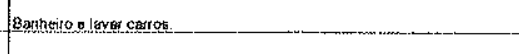 & 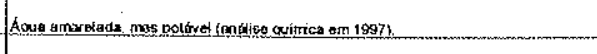 \\
\hline$\frac{16}{18}$ & 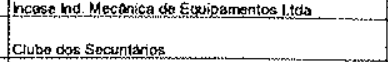 & 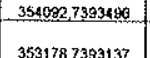 & suntsorstas & $\overbrace{1989}^{1996}$ & -200 & & & 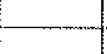 & 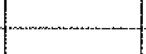 & & & Anstastavate & nneo & 30.0 & & & 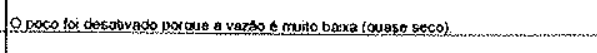 \\
\hline 20 & 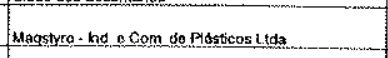 & 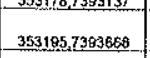 & 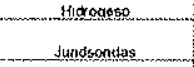 & 年 & $\frac{2200}{350}$ & 317.50 & & 1.18 & $12 \infty$ & & & cosostatos & $-\sin$ & & & 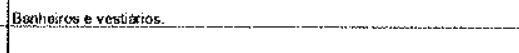 & 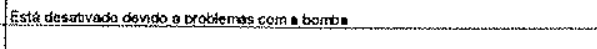 \\
\hline 30 & Congatelex & .355514,7392739 & & 1983 & 80 & & & 2.000 & 21206 & 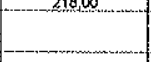 & . & onstersate & 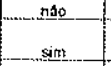 & 11.5 & 20400 & & 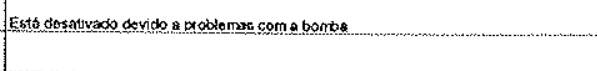 \\
\hline-35 & 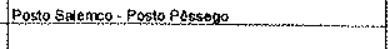 & 355790,3929181 & & $\ldots$ & 132 & & 2002 & & & & & 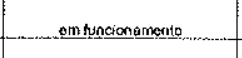 & noo & & & Laxpectuses. & \\
\hline 36 & 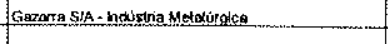 & 355692:7991740 & 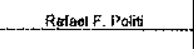 & -1990 & .184 & 254 & & 3.77 & -16 & $\infty$ & & Dosostivater & nosoc & & -1300 & 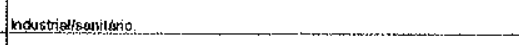 & 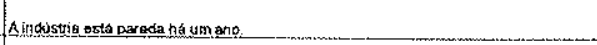 \\
\hline-38 & 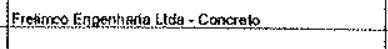 & . & Hitoroece- & 1995 & 200 & & .1 .25 & 800 & & & & 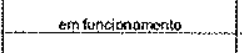 & im. & .600 & -800 & uso orat. & \\
\hline${ }^{40}$ & 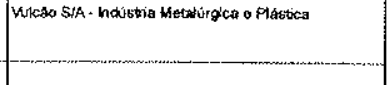 & 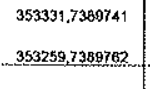 & Redaboua & \begin{tabular}{|l}
1089 \\
1993 \\
1993
\end{tabular} & $\begin{array}{r}170 \\
140 \\
\end{array}$ & & $0 . \infty$ & 0.00 & 24.00 & 80.00 & 0.069 & 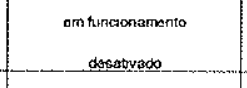 & sin & & 80.0 & |uso ocatal. & EF \\
\hline 45 & 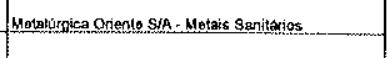 & - & & 1976 & 340 & $-203 \times 20$ & 1.203 & -2.00 & 8.00. & -8200 & 0.025 & ontunconaramento & $\operatorname{sim}$ & 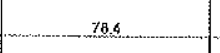 & & 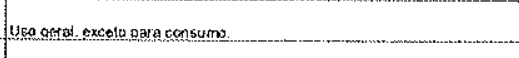 & mant \\
\hline 50 & 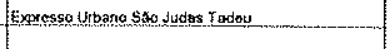 & 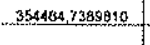 & Goospon & r.1995... & 98 & & & & . 55,00 & & & donstrate & $\mathrm{n}_{\mathrm{n}}^{\mathrm{nag}}$ & -980 & & & \\
\hline 64 & 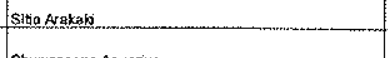 & . 359316,7391686 & s.sontonara & -1997. & -1.182 & 311.15 & & 25 & 6.6130 & 139.50 & 0.019 & . entuncionaranonto & nno & -620 & & 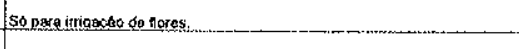 & \\
\hline${ }_{88}^{88}$ & 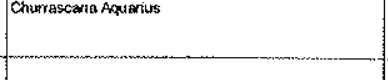 & 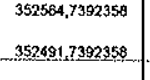 & 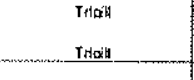 & \begin{tabular}{|l}
1980 \\
89898 \\
\end{tabular} & $\begin{array}{l}150 \\
1800 \\
\end{array}$ & & & & & & & 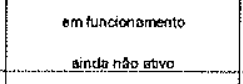 & nao & & & 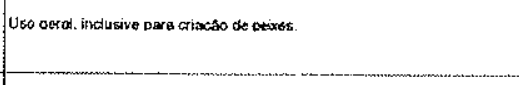 & 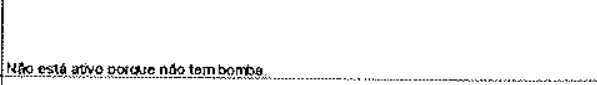 \\
\hline$-n$ & 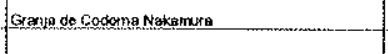 & 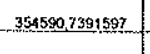 & sundsandatas. & 1998 & 340 & -311.15 & .800 & 8.80 & 9.90 & 15539 & 0.005 & 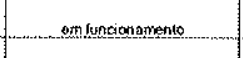 & n $\mathrm{nso}_{\mathrm{s}}$ & $\ldots$ & & & \\
\hline 13 & 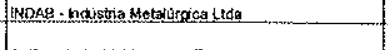 & .3540068 . 399124 & Trinal & .1988 & 200 & & 200 & & & & & 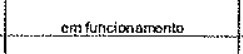 & nabo & & & & \\
\hline 32 & 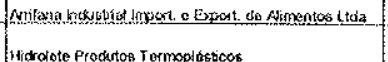 & . & Triat... & 1991. & -.160 & & 0.020 .033 & 3.30 & & & & 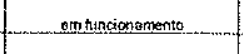 & $\ln _{\mathrm{na}}$ & -25.0 & & 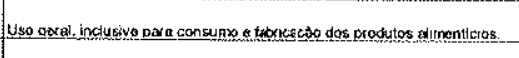 & \\
\hline 101 & 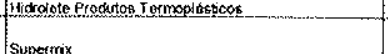 & 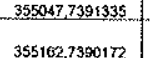 & & $-1995-$ & -120 & & & - -1.50 & 1000 & & & entungomanamentio & sim. & $\ldots$ & & 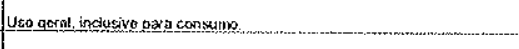 & \\
\hline 107 & Sustatix & 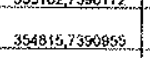 & 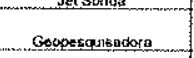 & -1000 & 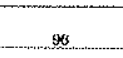 & & 125 & & & & & 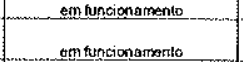 & noo & & & 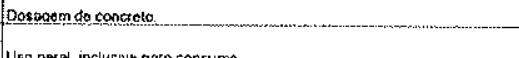 & \\
\hline 109 & 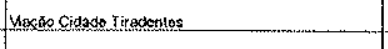 & .356031,739202000 & sunsosender & -1994 & 3.3 .3 & 37465 & & $=2,00$ & 0.0000 & 177,00 & 0.014 & 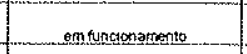 & sim & 5.550 & 179.0. & 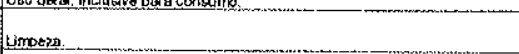 & 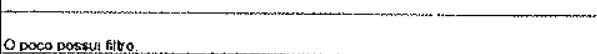 \\
\hline .113 & congeconsturese & .352806073901437] & & 1998 & & & & & & & & & & & & & ( \\
\hline $\begin{array}{l}115 \\
115 \\
\end{array}$ & Carreterur Passopos & 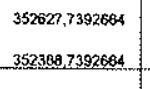 & Hididatesos & .1997 & 244 & $25,0.2$ & & 1.87 & 8.50 & 122.98 & 0.013 & 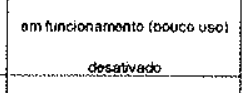 & 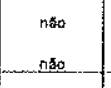 & 420 & 182.02 & & 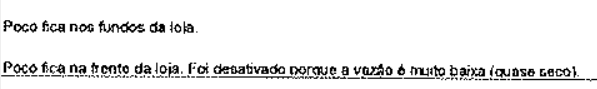 \\
\hline 110 & 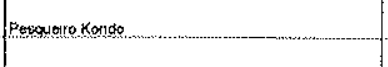 & .35s597,7392014.4. & 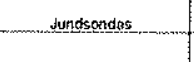 & 1987 & -.209 & -31115 & & $-15,20$ & 10.12 & 11323 & 0,139 & eenturiomannento & & $-50,0.0$ & 1260 & & \\
\hline & & $3553545,79393202]$ & & & & & & & & & & 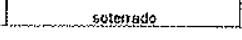 & & & & & \\
\hline
\end{tabular}




\begin{tabular}{|c|c|c|c|c|c|c|c|c|c|c|c|c|}
\hline Nede En Enoresa & 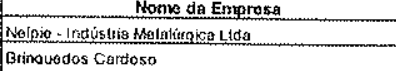 & 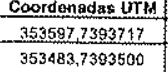 & Alloporte & & Dimatro (mily & Vazato da Uso $\left(m^{3} m\right)$ & Nivol Estatiko, (m) & 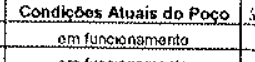 & 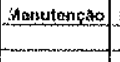 & 荲omba & Uso & \\
\hline 5 & & 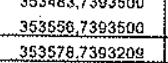 & & $\begin{array}{lll}10.000 \\
1.500\end{array}$ & & & & 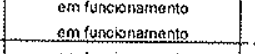 & & & (2) & \\
\hline$\frac{6}{6}$ & 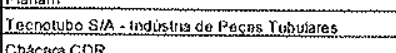 & 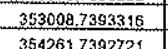 & & & & & & 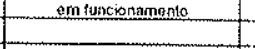 & & & 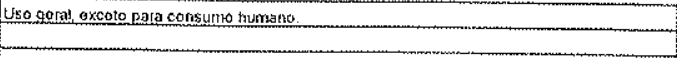 & \\
\hline $\begin{array}{cc}11 \\
11 \\
11\end{array}$ & & 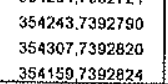 & & $\begin{array}{l}8.28 \\
5.20 \\
5.28 \\
100\end{array}$ & $\begin{array}{l}\substack{1,10 \\
i, 10 \\
i, 10} \\
0.10\end{array}$ & 0.25 & $\begin{array}{l}6.53 \\
3.74 \\
3.14\end{array}$ & 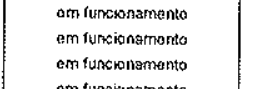 & 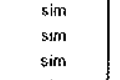 & 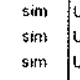 & 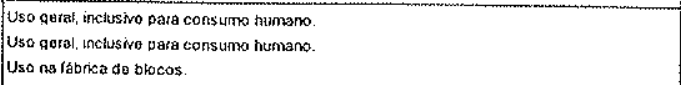 & 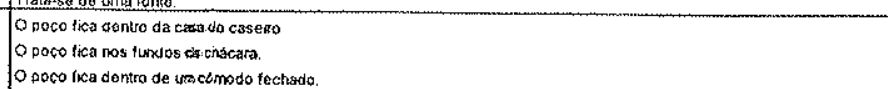 \\
\hline 然 & 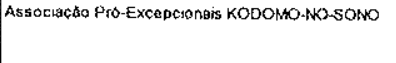 & 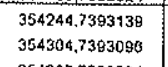 & & $\begin{array}{l}2.60 \\
3.80\end{array}$ & 1.00 & & 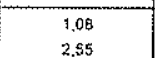 & 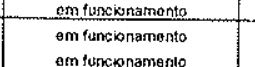 & & $\frac{s \mathrm{sm}}{\mathrm{sim}}$ & 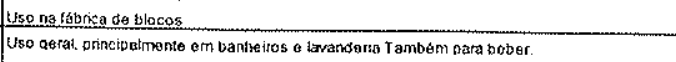 & 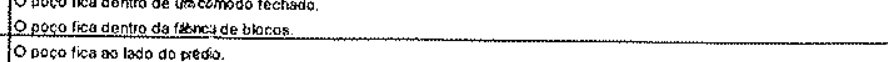 \\
\hline 染 & & 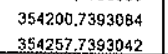 & & $\begin{array}{c}5,80 \\
470\end{array}$ & $\begin{array}{c}1.20 \\
2.80\end{array}$ & & 染, 40 & 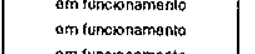 & & $\begin{array}{c}\operatorname{sim}_{\mathrm{sim}} \\
\mathrm{sin}\end{array}$ & 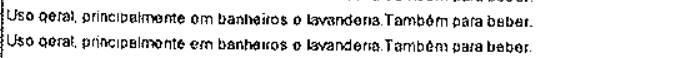 & 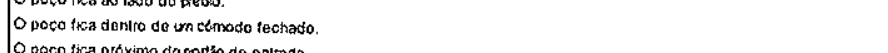 \\
\hline$\frac{14}{17}$ & 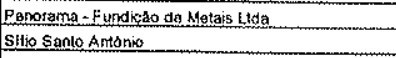 & 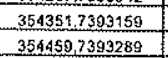 & 1989 & $\frac{5.50}{5.50}$ & & & & 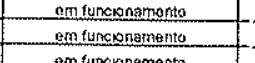 & & $\mathrm{sm} / \mathrm{s}$ & 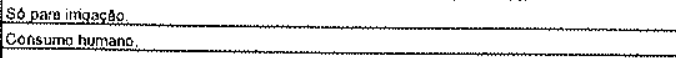 & 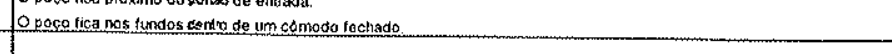 \\
\hline$\frac{22}{24}$ & 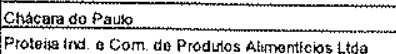 & 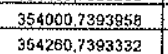 & $\frac{1968}{1967}$ & $\frac{11,00}{8.40}$ & $\frac{1.60}{2.25}$ & $\frac{0,06}{125.106}$ & $\frac{9.50}{0.50}$ & 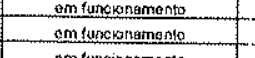 & Naso & $\operatorname{sim}[t$ & 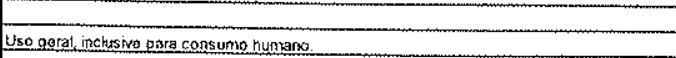 & \\
\hline $\begin{array}{l}24 \\
24 \\
24 \\
24\end{array}$ & a & 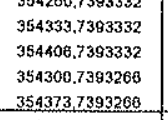 & 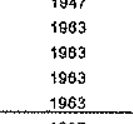 & 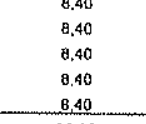 & $\begin{array}{l}2.26 \\
1.10 \\
1.10 \\
1.10 \\
-1.10 \\
\end{array}$ & & 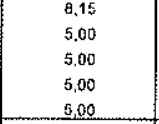 & 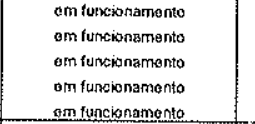 & & 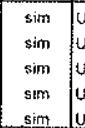 & 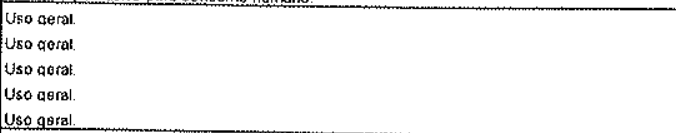 & 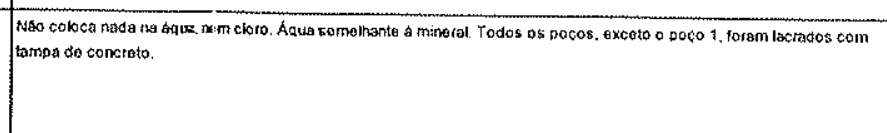 \\
\hline $\begin{array}{l}25 \\
25\end{array}$ & 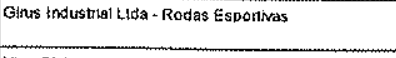 & 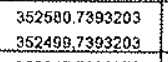 & $\begin{array}{l}1997 \\
1995 \\
\end{array}$ & 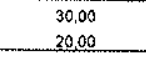 & $\begin{array}{l}1,150 \\
1.00\end{array}$ & 0.210 .42 & 4.78 & 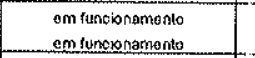 & $\underset{\substack{\operatorname{sim} \\
\text { sim }}}{s}$ & $\frac{s i m}{\sin } \int_{4}^{4}$ & 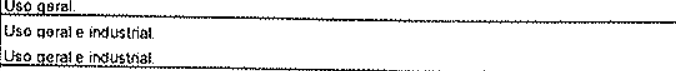 & 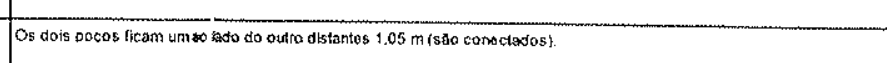 \\
\hline${ }_{26}^{28}$ & Wac ciluos & 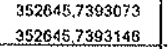 & 1955 & 6.10 & 1.00 & & 4.59 & 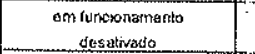 & & $\sin p^{4}$ & 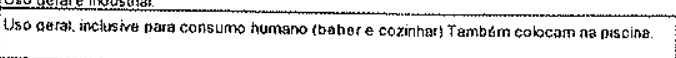 & 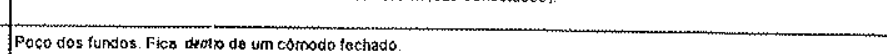 \\
\hline${ }_{31}^{31}$ & 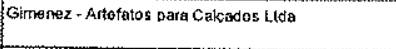 & 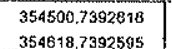 & $\begin{array}{l}\text { ansiboo } \\
\text { 1997 }\end{array}$ & $\begin{array}{l}8.96 \\
322.2\end{array}$ & $\begin{array}{l}0.80 \\
0.80\end{array}$ & & $\begin{array}{c}7.20 \\
2880\end{array}$ & 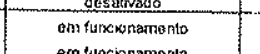 & sim & sim & 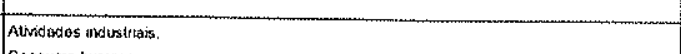 & 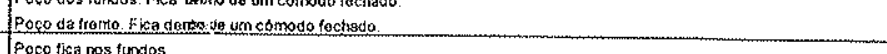 \\
\hline 41 & 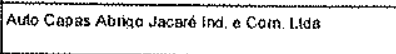 & 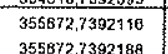 & 1085 & $\begin{array}{l}18.00 \\
2.47\end{array}$ & & $0.08^{\circ}$ & $\begin{array}{l}3.00 \\
3.00 \\
.10\end{array}$ & 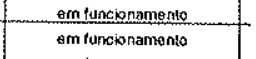 & $\frac{\operatorname{sim}}{\operatorname{sim}}$ & $\frac{\operatorname{sim}}{\sin t_{i}}$ & 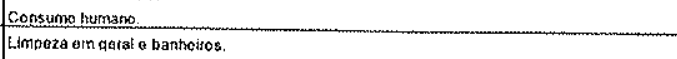 & 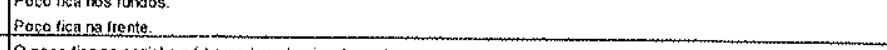 \\
\hline$\frac{44}{48}$ & 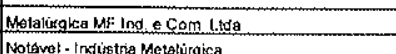 & 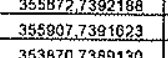 & 1993 & 5.00 & $\frac{1.50}{5.50}$ & & 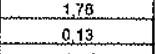 & 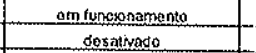 & $\operatorname{sim}_{\text {nom }}$ & $\frac{\operatorname{sim}}{r i s}$ & 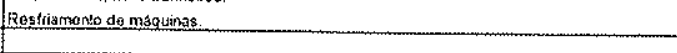 & 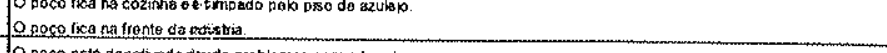 \\
\hline$\frac{8}{48}$ & 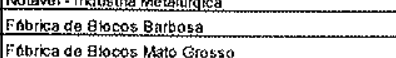 & 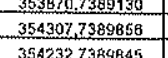 & & 年, $\frac{1200}{-.98}$ & 0.93 & & $\frac{60.00}{6.78}$ & 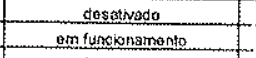 & $\frac{m a d}{s m m}$ & 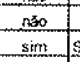 & & 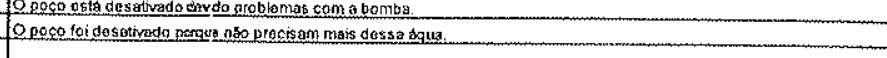 \\
\hline - & & 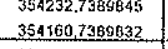 & 1989 & $\begin{array}{l}4.58 \\
289 \\
\end{array}$ & 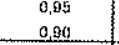 & & $\begin{array}{l}3.38 \\
2.35 \\
\end{array}$ & 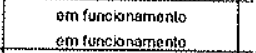 & $\operatorname{sim}$ & $\operatorname{sim}_{\substack{\text { sim } \\
\text { sing }}}$ & Iso oferat. & \\
\hline$\frac{51}{52}$ & 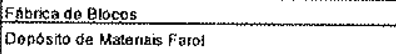 & 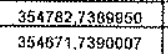 & $1978 ?$ & $\frac{529}{1549}$ & $\frac{1.09}{0.09}$ & & 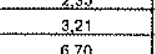 & 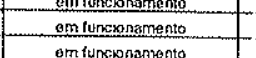 & & $\frac{\sin }{\sin t}+2$ & Vocherabocoss. & 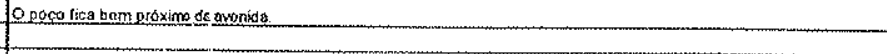 \\
\hline 52 & & 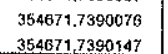 & ( & $\begin{array}{l}0,68 \\
3 \gamma_{0}\end{array}$ & $\begin{array}{l}0.00 \\
1.00 \\
0.00\end{array}$ & & 0 & 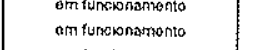 & & 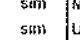 & 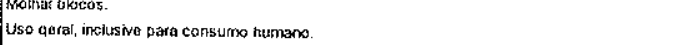 & 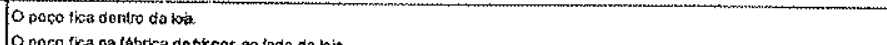 \\
\hline $\begin{array}{llll}53 \\
53\end{array}$ & 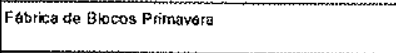 & 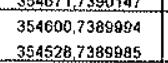 & 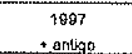 & $\begin{array}{l}8.65 \\
8.60 \\
\text { son }\end{array}$ & $\frac{1.00}{1.00}$ & 0.21 & $\frac{1.17}{9.27}$ & 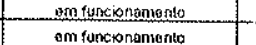 & & $-\operatorname{sim} 11$ & 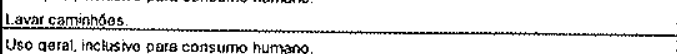 & 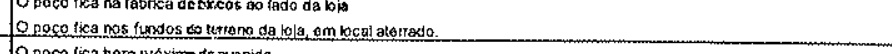 \\
\hline $\begin{array}{cc}54 \\
54\end{array}$ & 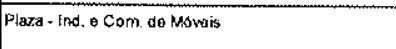 & 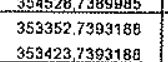 & 1083 & $\begin{array}{l}2.000 \\
2000\end{array}$ & & & & 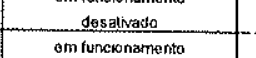 & inso & $\sin \rceil^{\circ}$ & 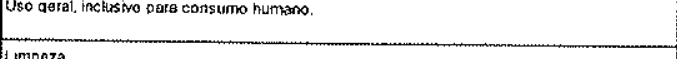 & 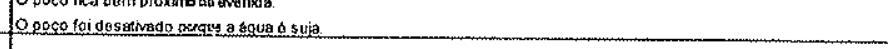 \\
\hline $\begin{array}{ll}55 \\
55\end{array}$ & 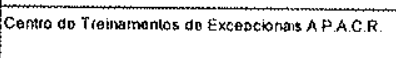 & 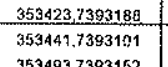 & & 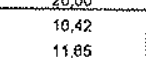 & $\begin{array}{l}1.20 \\
1.00\end{array}$ & 0.420 .50 .50 & 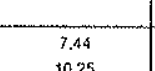 & 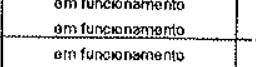 & & & 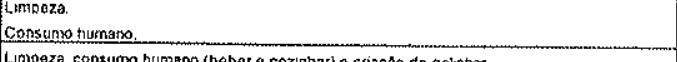 & \\
\hline .55 & 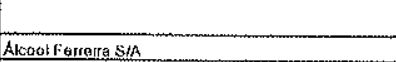 & 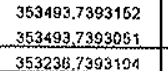 & 1998 & $\begin{array}{l}6.705 \\
6.75\end{array}$ & $\begin{array}{c}\frac{1.00}{100} \\
-\end{array}$ & & $\begin{array}{l}\begin{array}{l}10.25 \\
5.35\end{array} \\
5,35\end{array}$ & 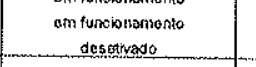 & & 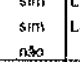 & 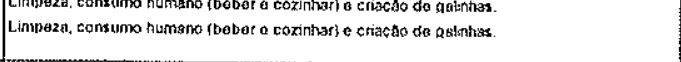 & 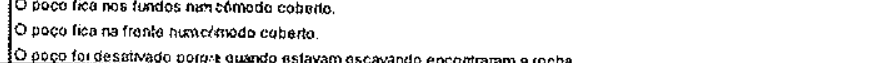 \\
\hline $\begin{array}{l}58 \\
58 \\
6 \mathrm{~B}^{2}\end{array}$ & Chickeca Natasosone & 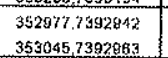 & 1953 & 4,40 & 1.20 & 0.12 & 2.12 & 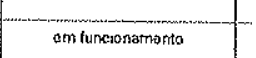 & & 年 & 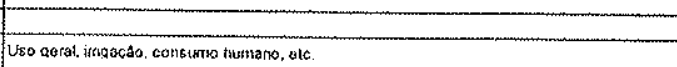 & 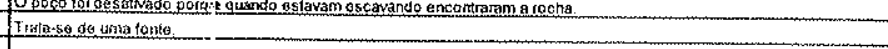 \\
\hline s.9. & 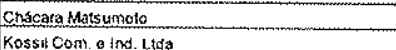 & 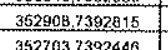 & $\frac{1958}{1058}$ & 2.295 & -100 & & ]$_{1.49}$ & 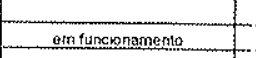 & man & (n) & & 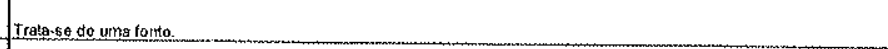 \\
\hline 81 & & 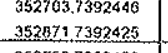 & 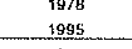 & 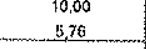 & 0.090 & 0.25. & & 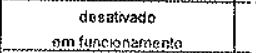 & & $\operatorname{sim}^{4}$ & 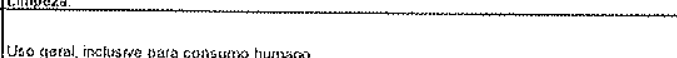 & 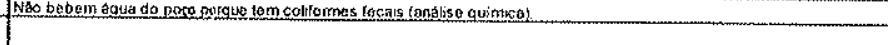 \\
\hline$\frac{62}{63}$ & 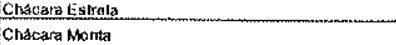 & 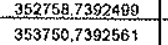 & $\frac{1985}{1880}$ & $\frac{5.00}{705}$ & $\frac{100}{1.30}$ & 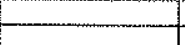 & $\frac{254}{690}$ & 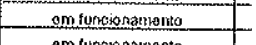 & simo & 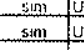 & 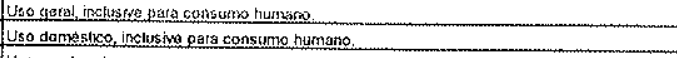 & 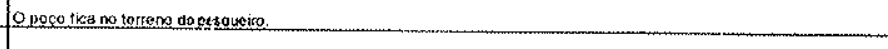 \\
\hline $\begin{array}{l}63 \\
63\end{array}$ & & 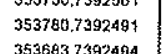 & 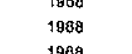 & 10.05 & 1.30 & & $\begin{array}{l}5.20 \\
5.00\end{array}$ & 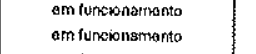 & 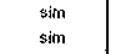 & $\operatorname{sim}_{\operatorname{sim}}^{0} \int_{u}^{0}$ & 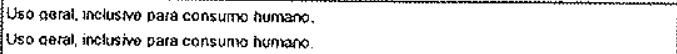 & 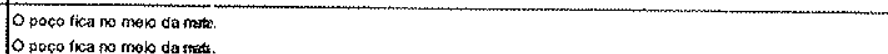 \\
\hline$\frac{89}{89}$ & & 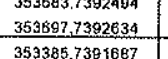 & & 7.70 & 0,80 & & & 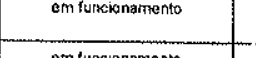 & & $\left.\mathrm{sim}^{\mathrm{m}}\right]_{\mathrm{H}}^{\mathrm{u}}$ & 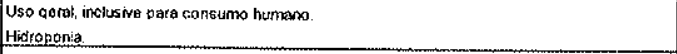 & 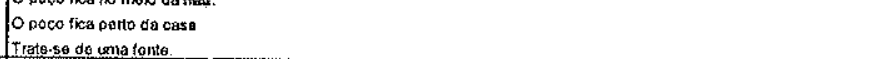 \\
\hline .65 & 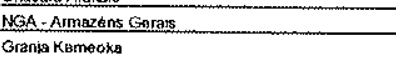 & 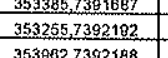 & $\frac{1986}{1906}$ & - & 105 & 0.020004 & 22,80 & 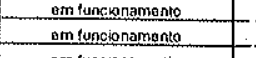 & & 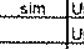 & 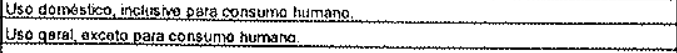 & 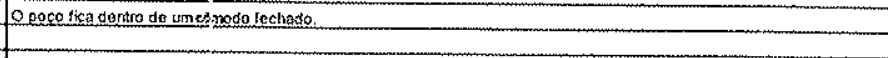 \\
\hline 告 & 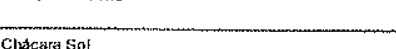 & 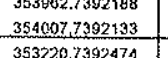 & 1088 & 5.22 & 2.00 & 0.03 & 3,42 & & nao & $\sin ^{\sin } \mathrm{h}^{2}$ & & 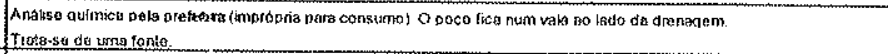 \\
\hline $\begin{array}{l}67 \\
67 \\
67 \\
67\end{array}$ & cibcarat Sor & 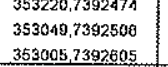 & $\begin{array}{l}1998 \\
1939 \\
\text { jag }\end{array}$ & $\begin{array}{l}4.69 \\
8.18 \\
\text { s. } 18\end{array}$ & 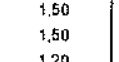 & & $\begin{array}{l}2.80 \\
5.22\end{array}$ & 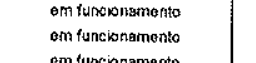 & 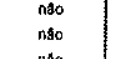 & 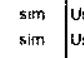 & 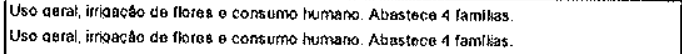 & 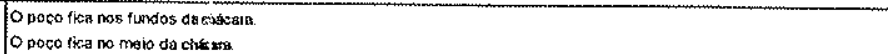 \\
\hline 斺0 & Sllio Jotos Owa & 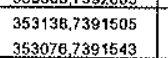 & $\begin{array}{l}1978 \\
1989\end{array}$ & $\begin{array}{l}3.81 \\
509\end{array}$ & 0.92 & 0,89 & . & 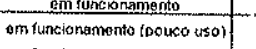 & nabo & 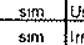 & 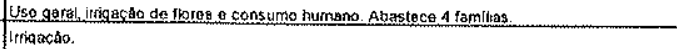 & 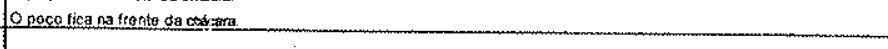 \\
\hline$\frac{71}{72}$ & 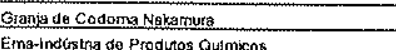 & 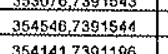 & $\frac{1089}{1098}$ & 2.3.320 & $\frac{1,00}{1,00}$ & $0.25: 029$ & . $\frac{0.39}{20.90}$ & 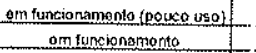 & . & $\frac{\sin l \mid}{\operatorname{sim} m}$ & 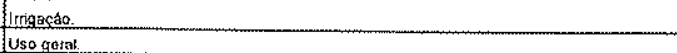 & \\
\hline 72 & & 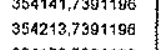 & $\begin{array}{c}1978 \\
0, \text { veltho }\end{array}$ & $\begin{array}{c}1.25 \\
8.25\end{array}$ & $\begin{array}{l}1.50 \\
0.80\end{array}$ & 0.12 & $\begin{array}{l}3.06 \\
3.30 \\
3\end{array}$ & 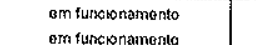 & $\operatorname{sim}_{\text {sim }}$ & $\sin 5$ & 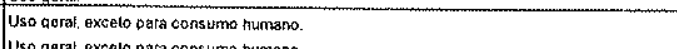 & 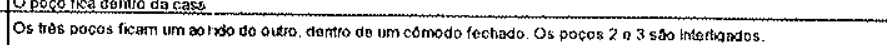 \\
\hline$\frac{72}{74}$ & S & 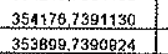 & 1978 & 10.54 & 1,170 & & $\begin{array}{llll}3.06 \\
3.65\end{array}$ & 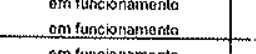 & 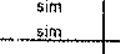 & 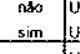 & 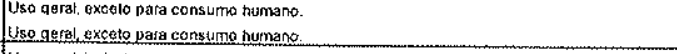 & \\
\hline$\frac{71}{-76}$ & 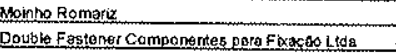 & 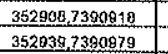 & & & & & & 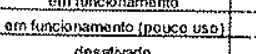 & & & 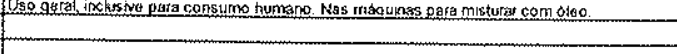 & \\
\hline $\begin{array}{l}{ }_{83}^{83} \\
\end{array}$ & 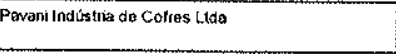 & 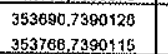 & $\begin{array}{l}1960 \\
1989\end{array}$ & $\begin{array}{l}2.2,43 \\
1958\end{array}$ & 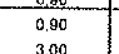 & & $\frac{13.50}{13.80}$ & 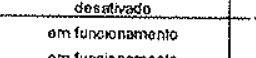 & nto & 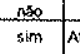 & & 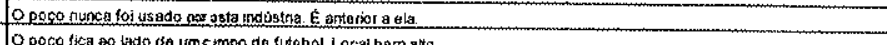 \\
\hline$\frac{89}{85}$ & 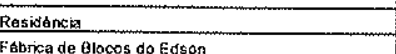 & 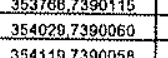 & $\frac{7989}{1989}$ & 19,56 & 3.300 & & $\frac{4.02}{4.00}$ & 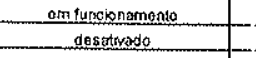 & & $\sin _{n \rightarrow \infty} \underbrace{A}$ & 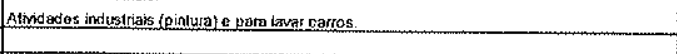 & 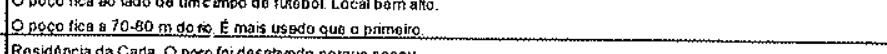 \\
\hline 整 & 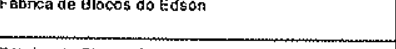 & 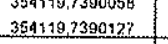 & & 5.928 & 俔o & & $\begin{array}{l}384 \\
7.65 \\
\end{array}$ & 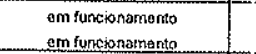 & noo & $\sin (x)$ & 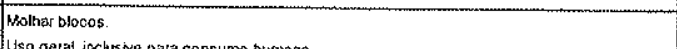 & 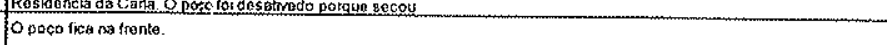 \\
\hline$\frac{86}{87}$ & 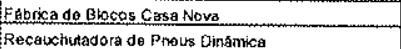 & 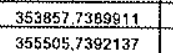 & $\frac{-1978}{1098}$ & $\frac{2.52}{100}$ & $\frac{.090}{100}$ & $\mathrm{G}$ & $\frac{106}{1.60}$ & 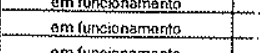 & & 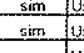 & 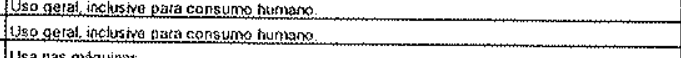 & 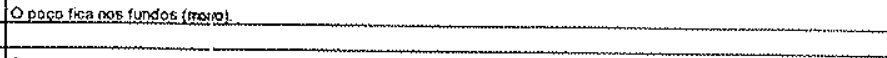 \\
\hline 整 & & 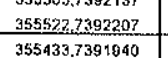 & 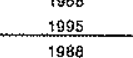 & 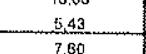 & $\frac{100}{100}$ & $0.21^{\circ}$ & $\begin{array}{l}303 \\
3.35 \\
309\end{array}$ & 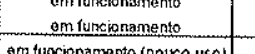 & 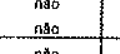 & $\sin ]_{0}^{0}$ & 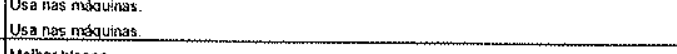 & 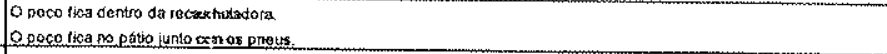 \\
\hline $\begin{array}{l}\frac{88}{89} \\
89\end{array}$ & 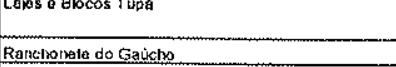 & 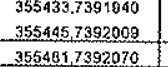 & $\begin{array}{l}1.968 \\
1969 \\
9898\end{array}$ & $\begin{array}{l}7.700 \\
\frac{70,00}{600}\end{array}$ & 1.00 & & 3.90 & 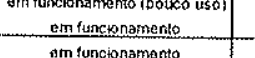 & 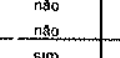 & 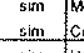 & 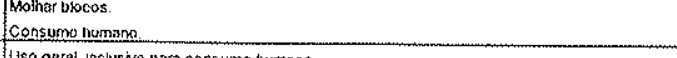 & 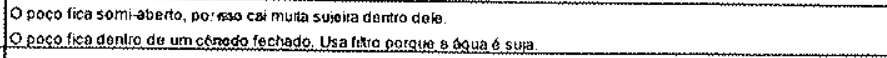 \\
\hline 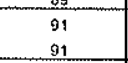 & 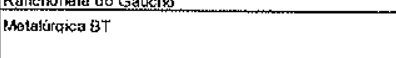 & 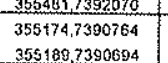 & 1986 & $\begin{array}{l}\frac{6.00}{3.23} \\
1.800\end{array}$ & 0.02 & 0.04 & 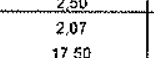 & 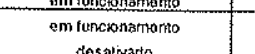 & $\operatorname{sim}$ & 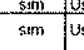 & 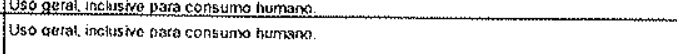 & 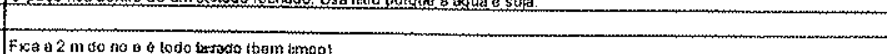 \\
\hline 94 & Mestativicica Gimmonor & 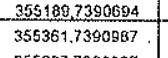 & 1978 & 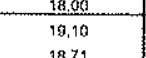 & $\begin{array}{l}0.05 \\
000\end{array}$ & $0.02^{2}$ & 10.80 & 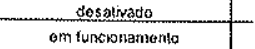 & s.so & & & 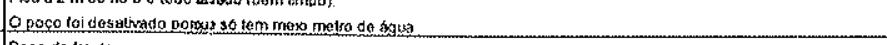 \\
\hline 朐的 & 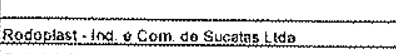 & 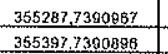 & $\frac{1.1999}{1999}$ & $\frac{1871}{1105}$ & $\frac{\frac{1.00}{1.20}}{1.0}$ & 0.06 & $\frac{17.18}{8.57}$ & 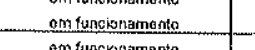 & sim & 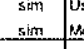 & 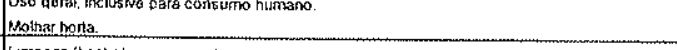 & 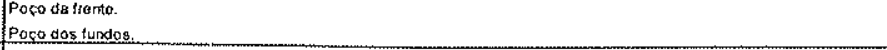 \\
\hline$\frac{97}{96}$ & 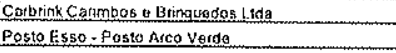 & 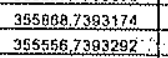 & -2 & 0.00 & & & & dostivatio & sum & 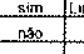 & 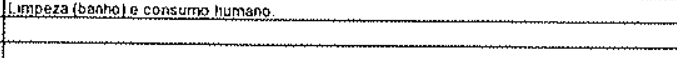 & \\
\hline 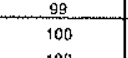 & 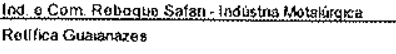 & 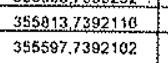 & 1987 & $\frac{4.00}{6.22}$ & & $0.09^{\circ}$ & & 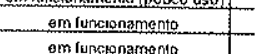 & 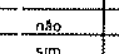 & $w_{0}$ & 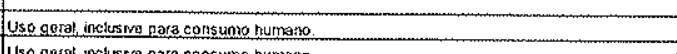 & \\
\hline 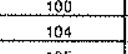 & 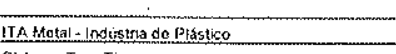 & 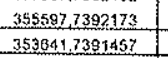 & 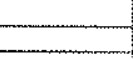 & $\begin{aligned} 7.30 \\
8.63 \\
\end{aligned}$ & $\frac{100}{1.00}$ & & 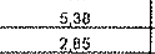 & 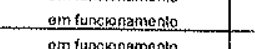 & & 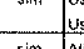 & 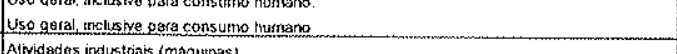 & 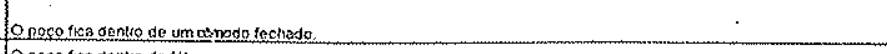 \\
\hline$\frac{-1.05}{106}$ & 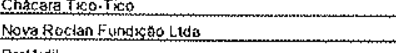 & 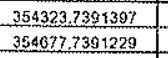 & 1967 & 1700 & & & & & & $\operatorname{sim} \mid A$ & 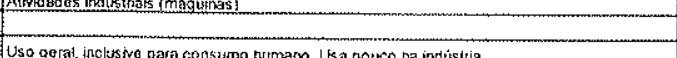 & 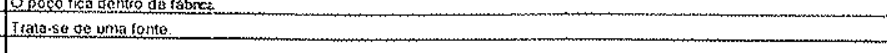 \\
\hline$\frac{1.18}{1+18}$ & 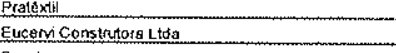 & 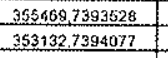 & 1078 & $\frac{4.00}{0.50}$ & & & & 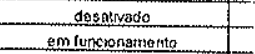 & 80 & 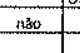 & 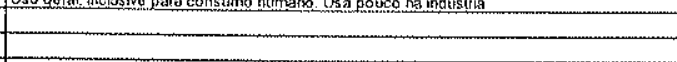 & 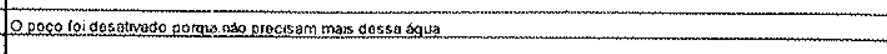 \\
\hline 117 & 烈 & 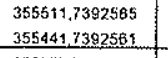 & & $\begin{array}{l}4.29 \\
3.70 \\
\end{array}$ & .1:0 & & $\begin{array}{l}3.19 \\
3.22 \\
\end{array}$ & 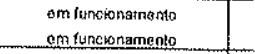 & & 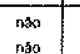 & & 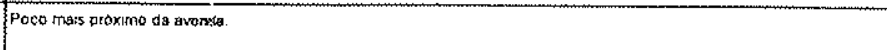 \\
\hline$\frac{118}{123}$ & 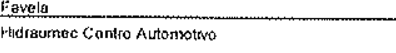 & 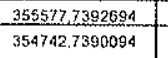 & & - $\frac{2.96}{3.47}$ & $\frac{105}{1.0}$ & & $\frac{1.84}{1.28}$ & 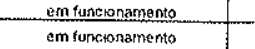 & & $\mathrm{sm}$ & & 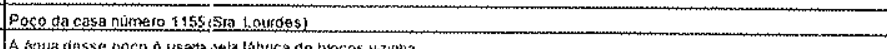 \\
\hline$\frac{1933}{124}$ & 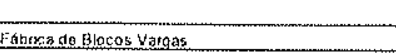 & 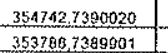 & $\frac{1391}{x-1}$ & $\frac{282}{47}$ & . 0.00 & & .1.55 & 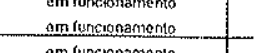 & & ${ }^{3 m}$ & 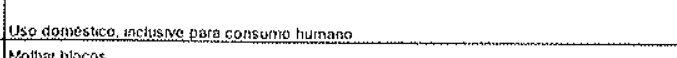 & 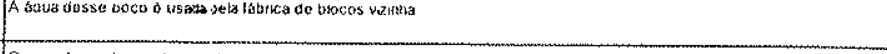 \\
\hline
\end{tabular}




\section{ANEXO 4}

RESULTADOS DAS ANÁLISES FISICO-QUIMICAS DAS ÁGUAS 


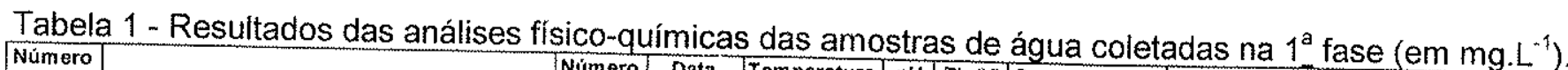

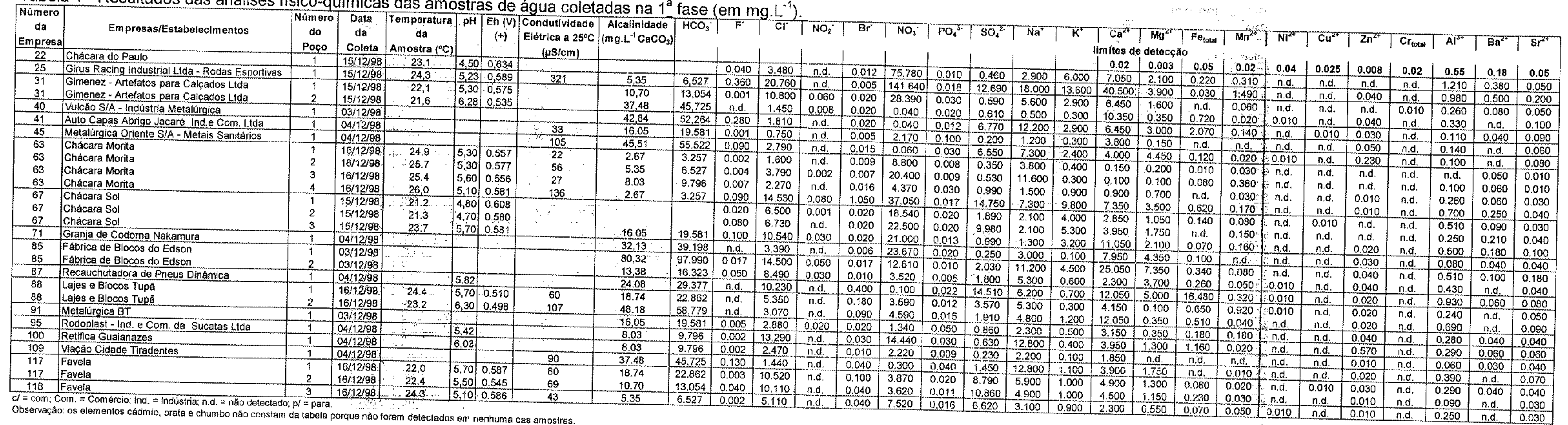

Tabela 2 - Resultados das análises físico-químicas das amostras de água coletadas na $2_{-}^{a}$ fase (em mg. $L^{-1}$ ).

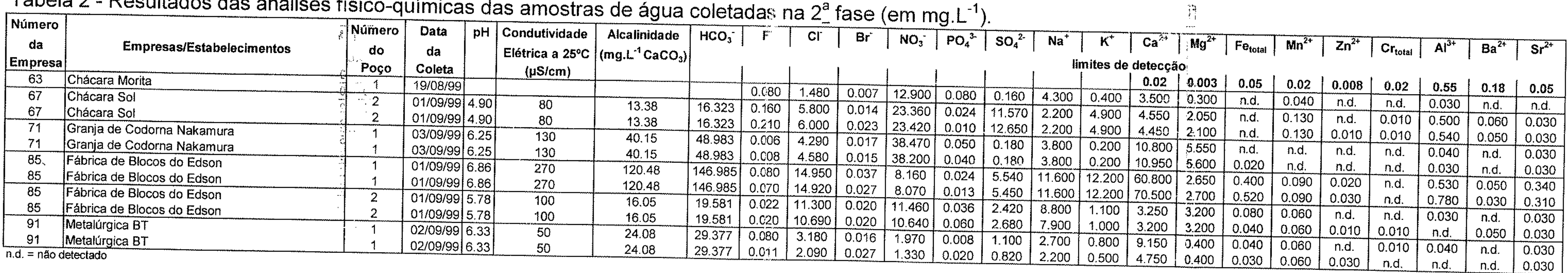

